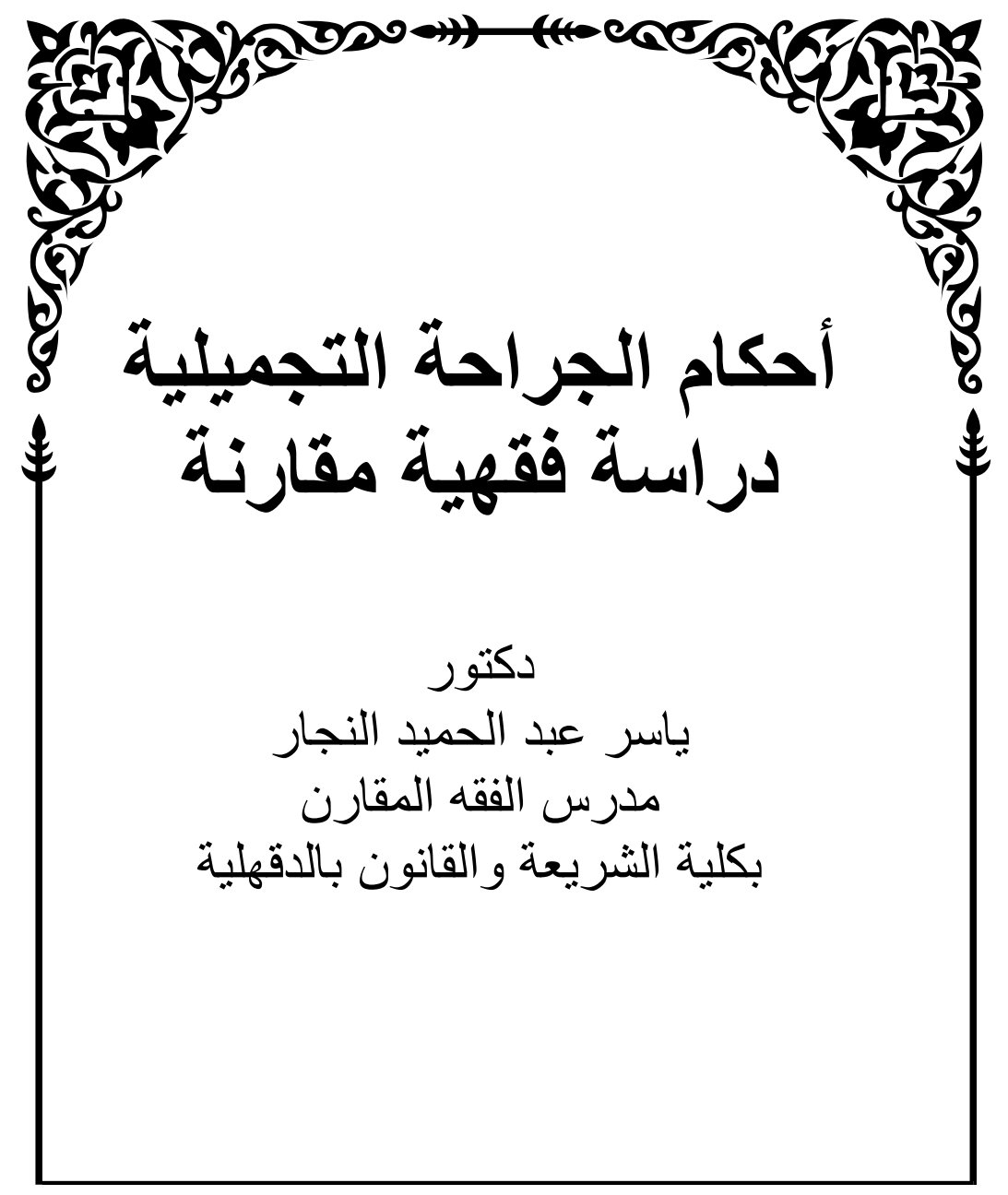




\section{المة المـــــة}

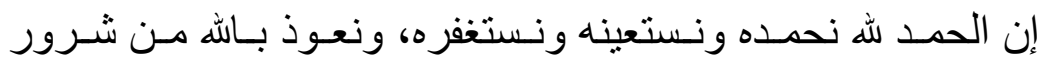

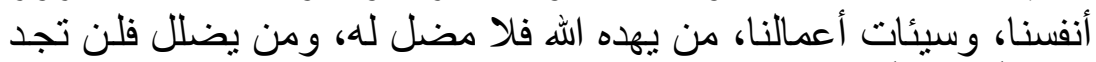

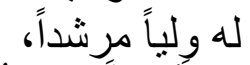

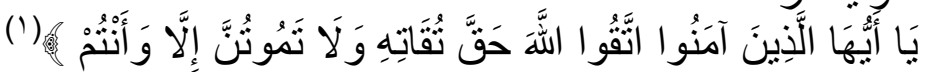

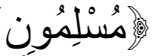

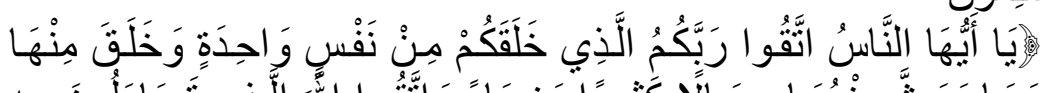

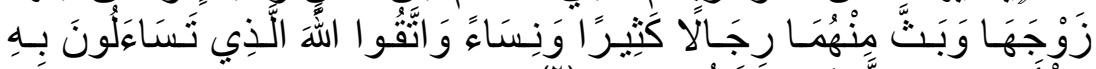

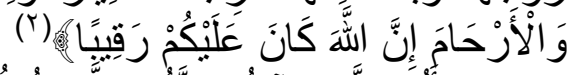

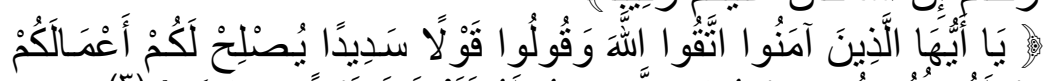

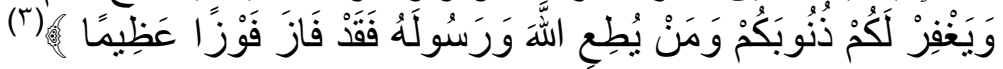

و أثشهح أن لا إله إلا الله وحده لا شـريك لله، وأشـهـ أن محمداً عبده ورسوله.

أما بعد:

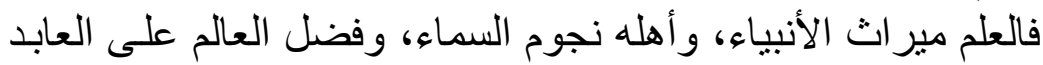
كفضل القمر على سائر الكواكب، ولو ولهياء، وزن حبر العلمـاء، ودم الشهداء لرجح مداد العلماء.

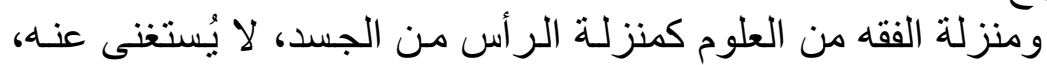

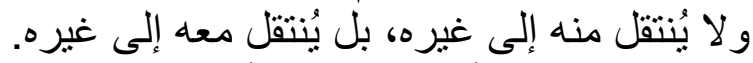

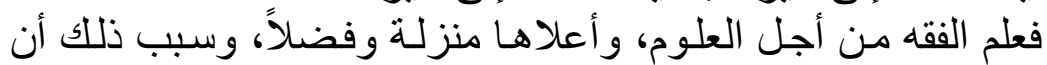

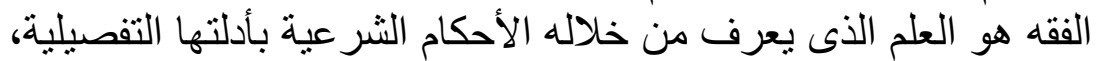

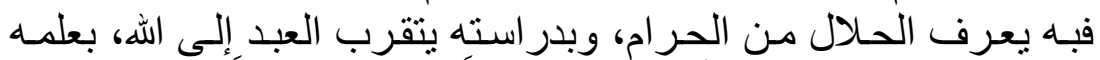

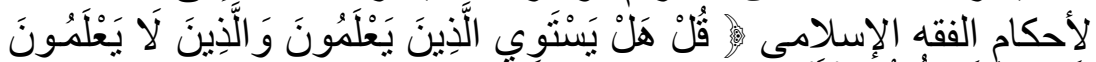

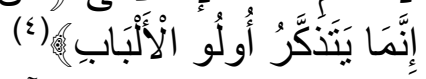

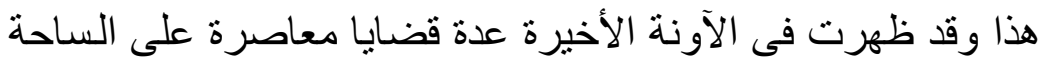

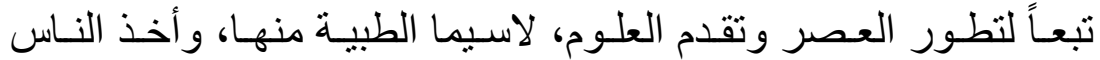
يباشرونها ويسألون عن بيان حكمها.

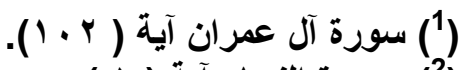

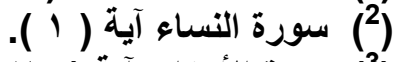

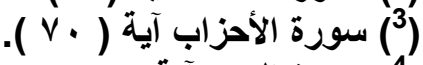

$$
\begin{aligned}
& \text { (4) سورة الزمر آية (9 (9) ). }
\end{aligned}
$$




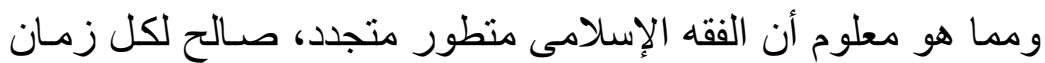
ومكان، حيث لا تخلو ا حادثة من حكم ميع تناهى الأدلة وكون المسائل و النوازل الفقهية لا لتنتاهى لاهي

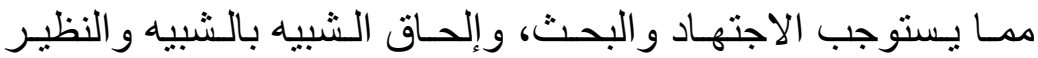

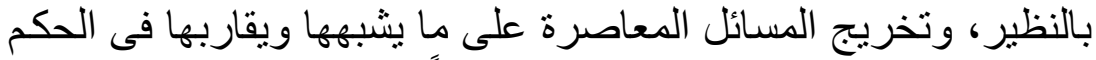
مما نص عليه فقهاؤنا الكرام فى كتبهـ قديماً.

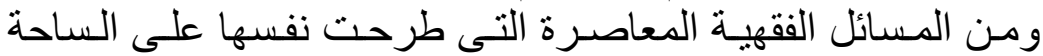

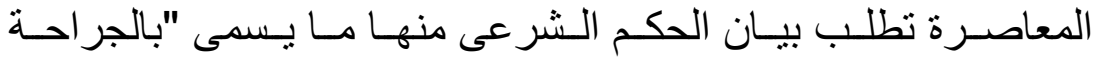

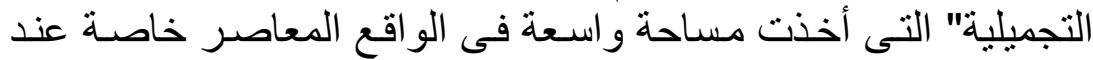

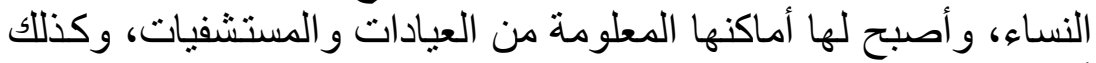

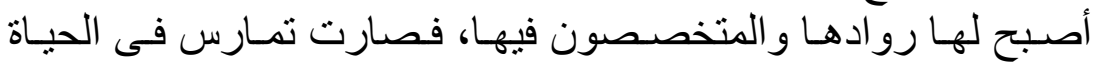
العملية على نطاق واسع. و وذذا البحث الذيى بين أيدينا يعـالج هذه القضية المعاصرة ويبين

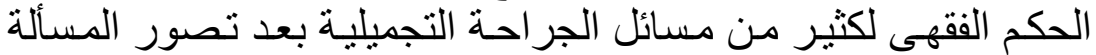

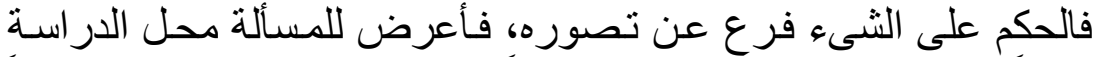

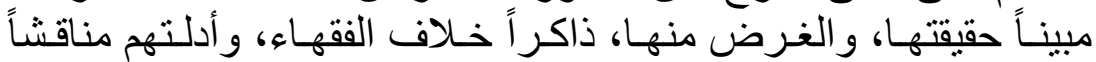
ومرجحاً متمماً البحث بـالقول المختار في أغلب المسائل الفقهية التى الفى تعرضت لها.

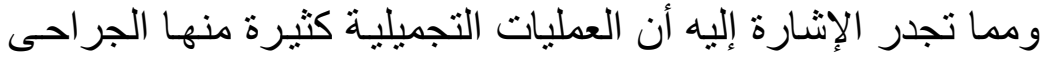

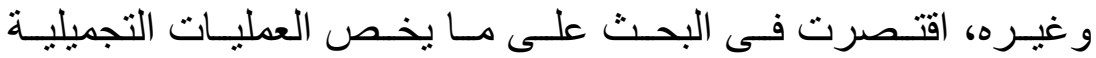
الجراحية، حيث ذكرت أثنهر المسائل التى تحتاج لبيان الحكم الفقهى.

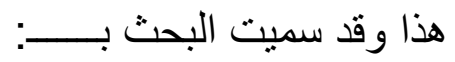
" أحكام الجراحة التجميلية " دراسة فقهية مقارنة.

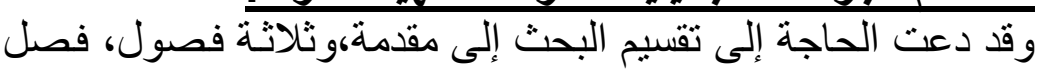
تمهيدى وفصلين رئيسيين:

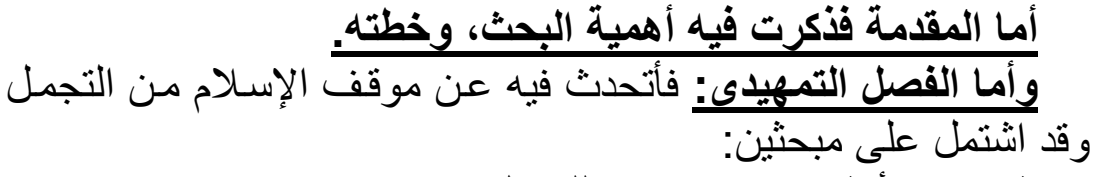
المبحث الأول: دعوة الإسلام للتجمل.

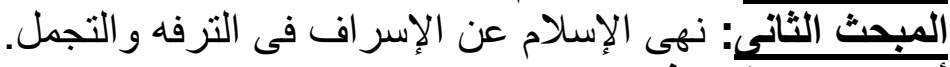

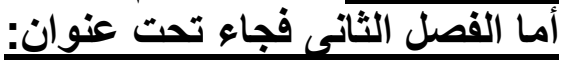

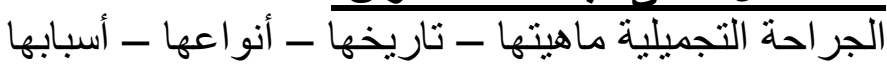

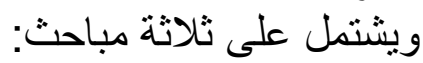


المبحث الأول: ماهية الجر احة التجميلية، وتاريخها. ويشتمل على مطلبين:

المطلب الأول: ماهية الجر احة التجميلية.

المطلب الثاني: تاريخ الجرالية الجرة التجميلية. المبحث الثاني: أنواع الجر الجراحة التجميلية، وأسبابها.

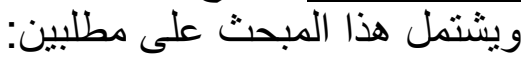

المطلب الأول: أنو اع الجراحة التجميلية.

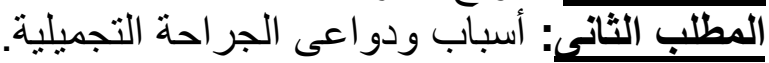

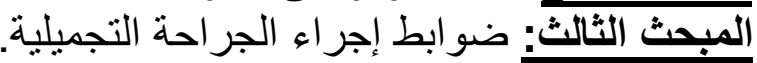

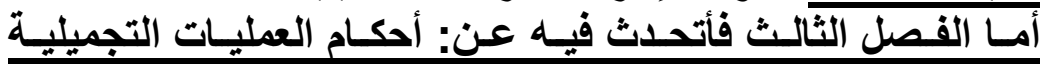
الجراحية ويشتمل على مبحثين: المبحث الأول:نماذجمنالعمليات الجراحية القديمة و أحكامها.

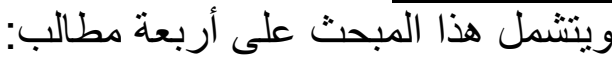
المطلب الأول: حكم الوشم، وحكم إز التهـ.

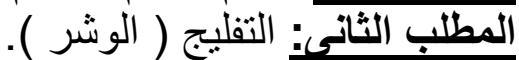
المطلب الثالث: ثقب أذن المر أنة لتعليق الحلق.

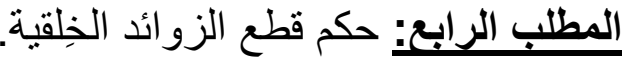

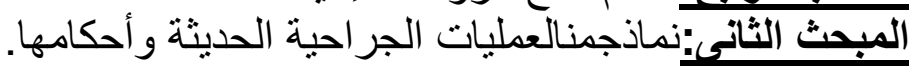
ويتشمل هذا المبحث على تسعة مطالب: المطلب الأول:جراحة تغئير الجنس.

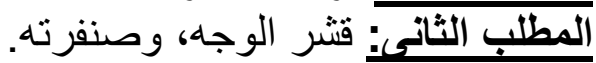

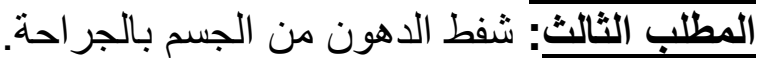

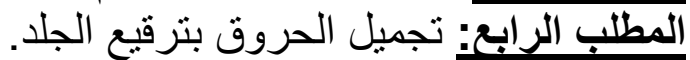

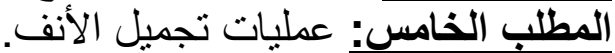

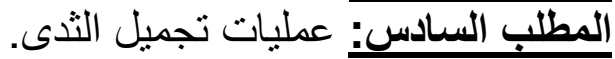

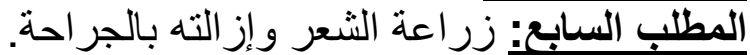

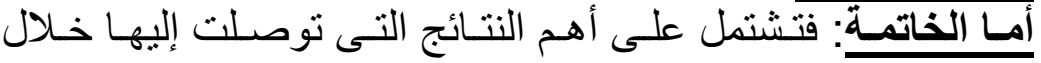
هذا وبالله التوفيق 


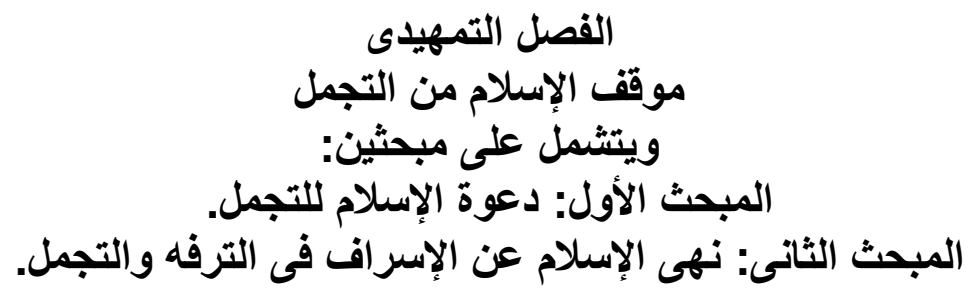




\section{بسم الله الرحمن الرحيم}

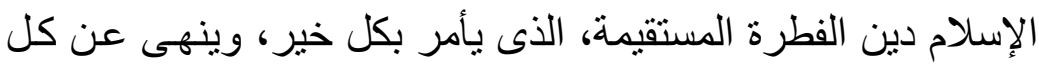

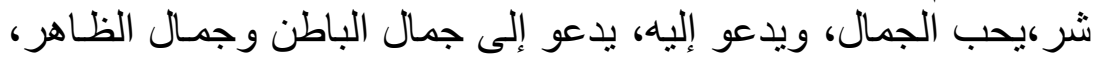

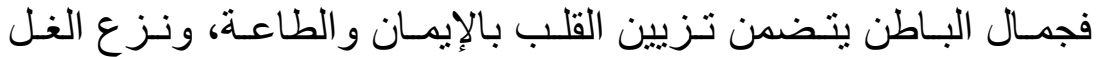

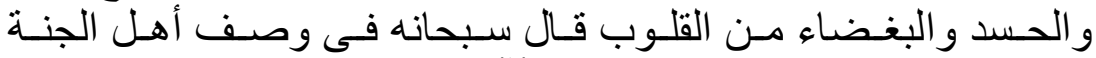

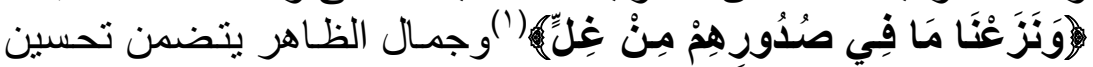

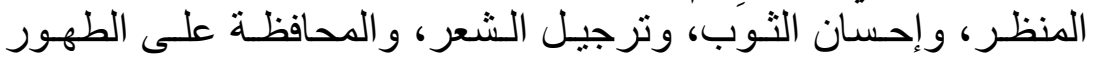

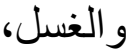

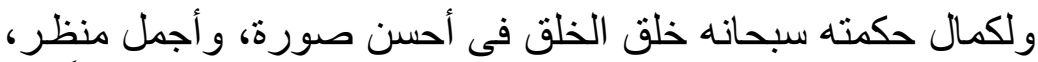

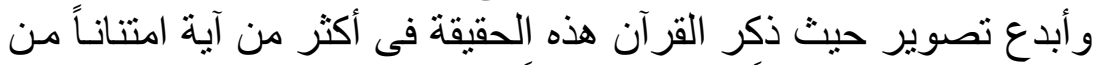

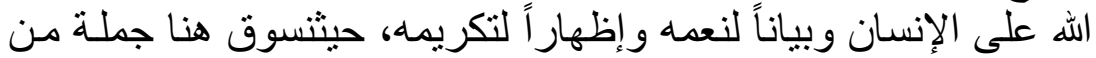
الآيات التى تنل على هذا المعنى قال جل و وعلا:

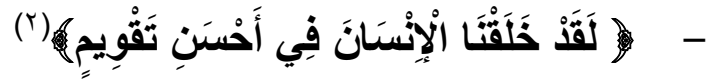

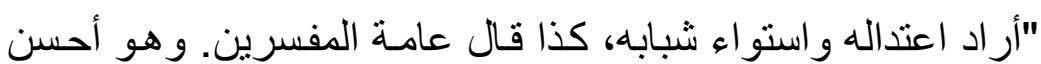

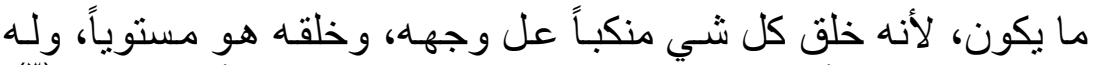

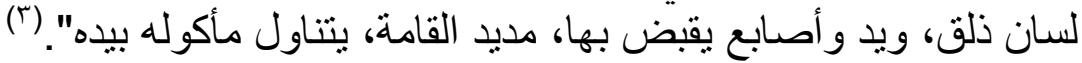

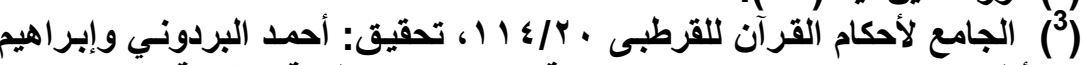

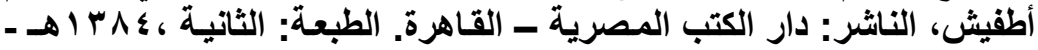

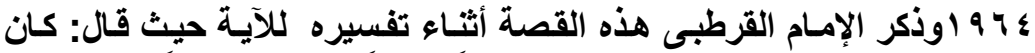

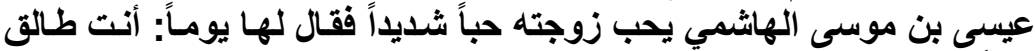

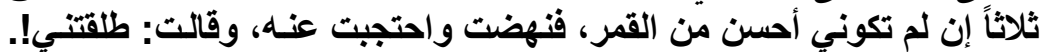
وبات بليلة عظيمة، فلما أصبح غدا إلى دار المنصور، فأخبره الخبر، وفئ وأظهر

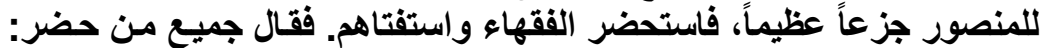

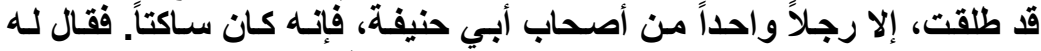

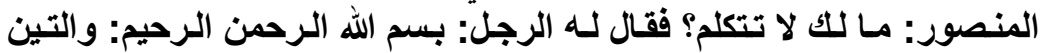

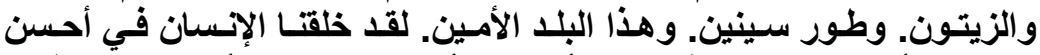

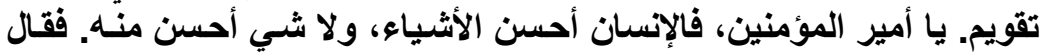

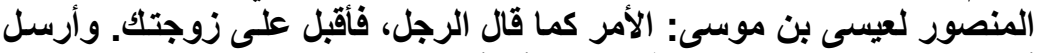

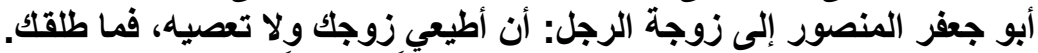

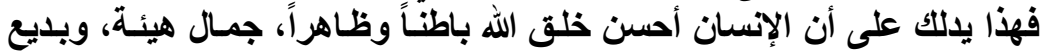
1111 


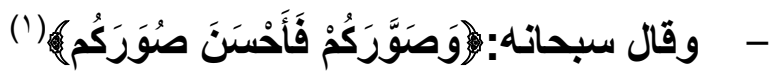
ومعناها: خلقكم في أحسن الأشكال، ومنحكم أكمل الصور فئمن في أحسن

تقويم، (r) تقاهن

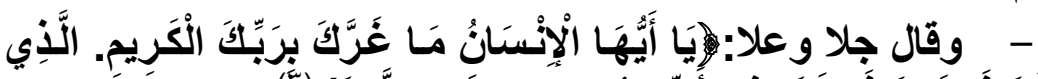

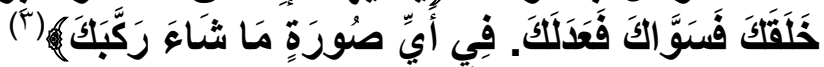

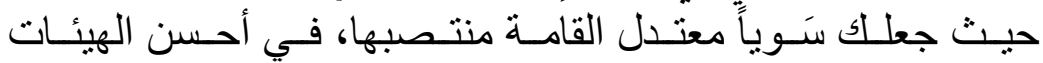

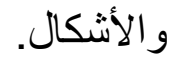

"و إن النظرة السريعة فضلاً عن النظرة الفاحصة لتقرر جمال هذا

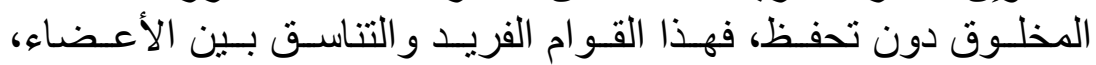

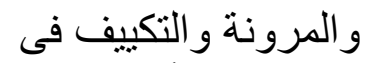

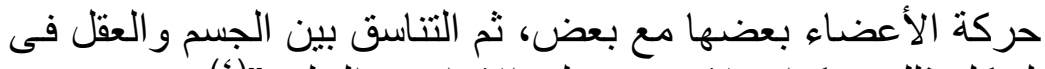

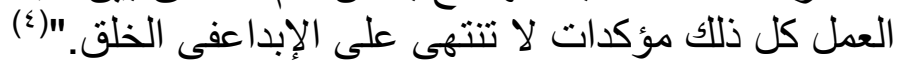
فهذه الآيات تفيد كلها معنى واحداً ألا وهو أن اله أبدع خلق الإنسان

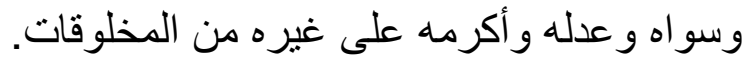

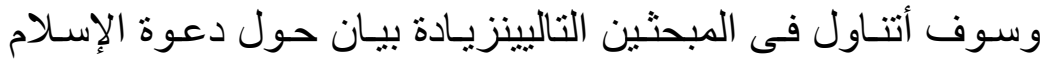
للتجمل، ونهيه عن الإسر اف فئاول فيها. المبحث الأول: دعوة الإسلام للتجمل الإنسل

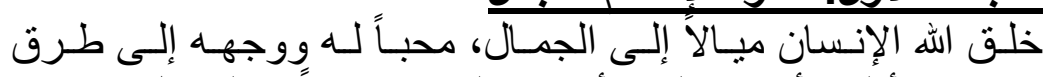

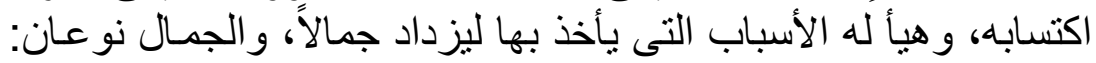

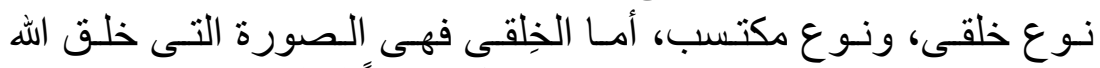

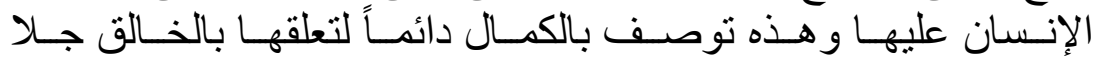

تركيب الرأس بمـا فيه، والصدر بمـا جمعه، والبطن بمـا حواه، والفرج ومـا

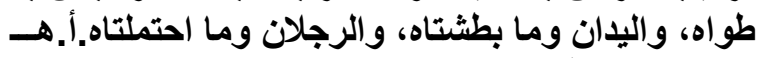

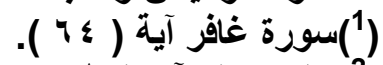

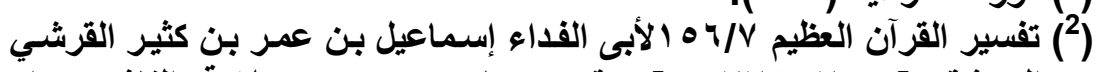

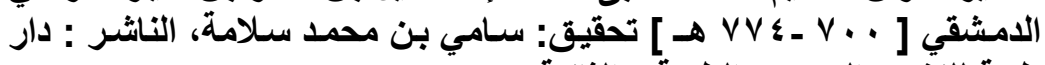

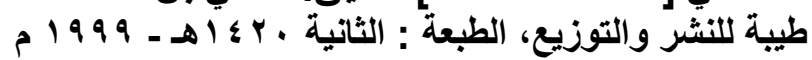

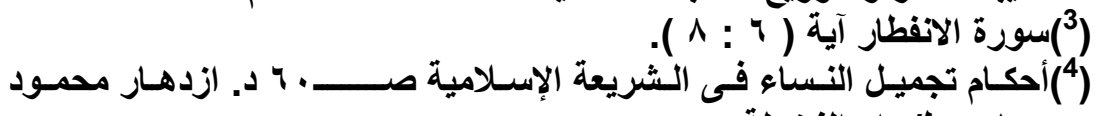
1119 


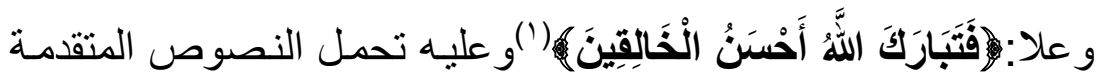

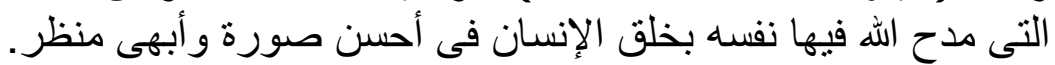

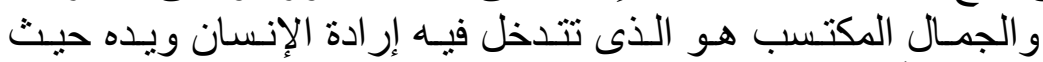

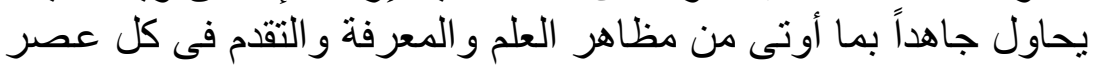

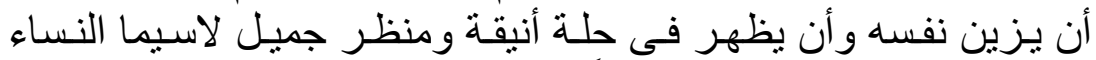

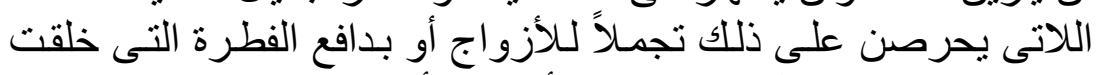

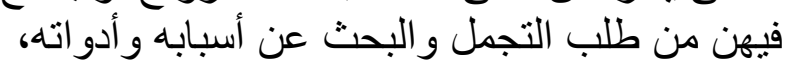
و الإسلام لايمنع من ذلك بل بل يحبه ويدعو إليه ويثيب علئ عليه أحياناً.

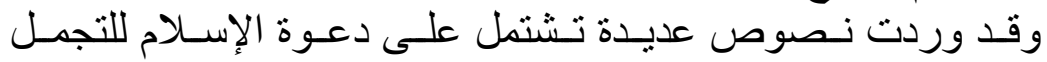

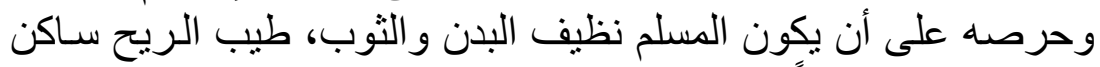

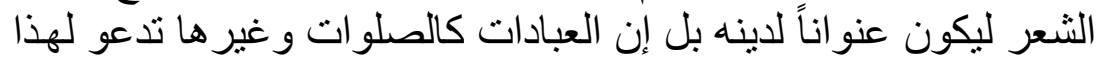

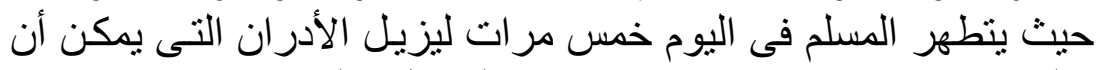

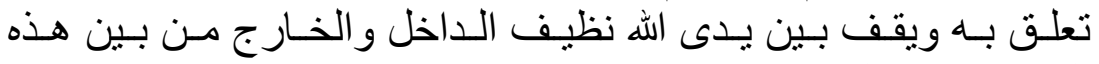

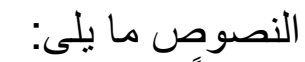

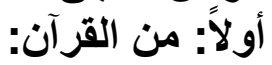

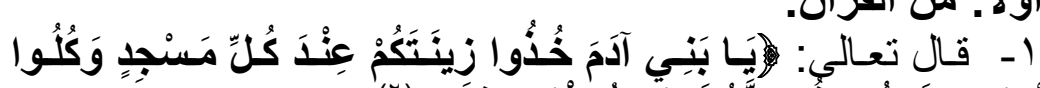

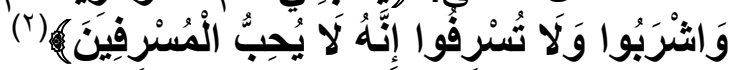

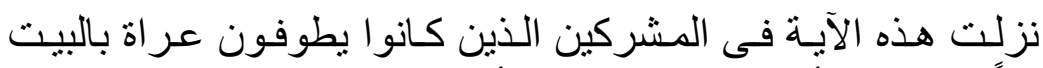

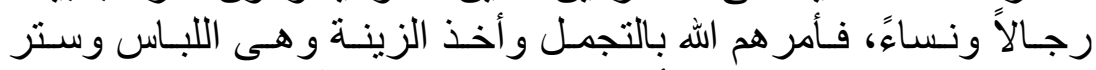

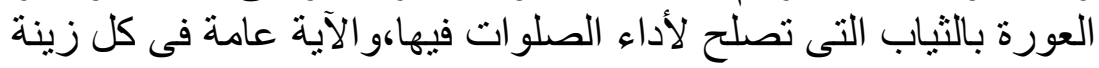

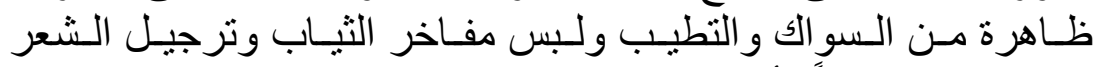

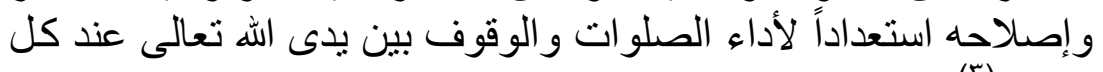

صلاة. (r)

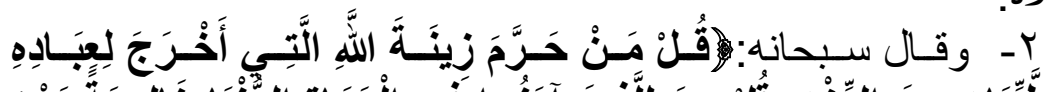

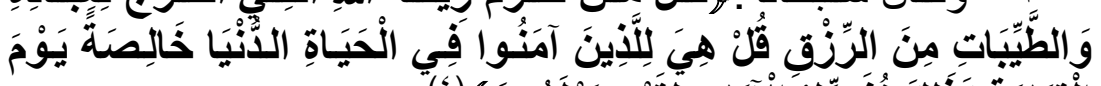

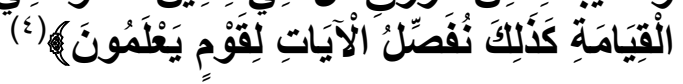

\footnotetext{
(1) (1) سورة المؤمنون آية (1) (1). (1).

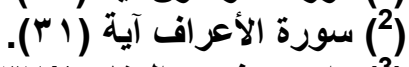

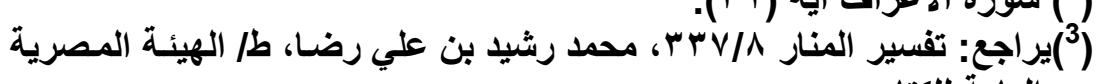
العامة للكتاب. (4)سورة الأعراف آية (r (r). NAT.
} 


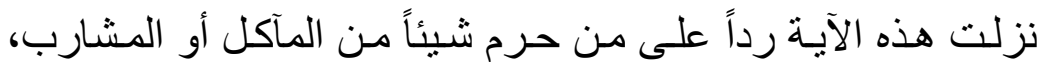

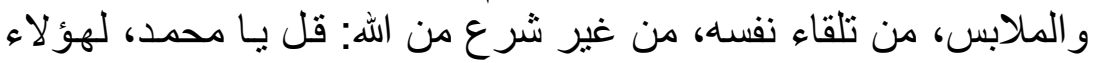

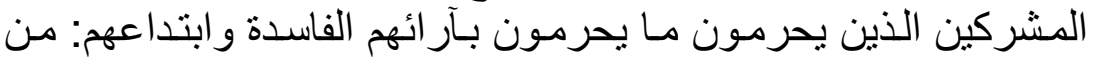

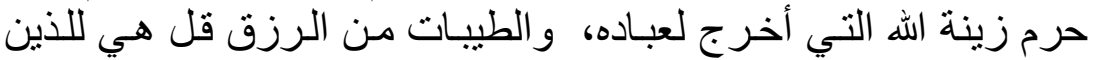

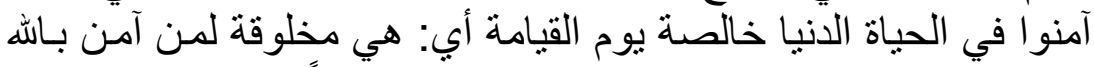

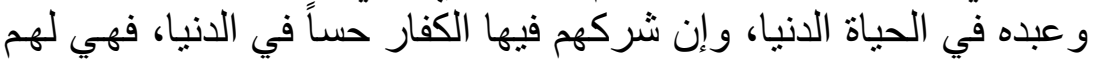

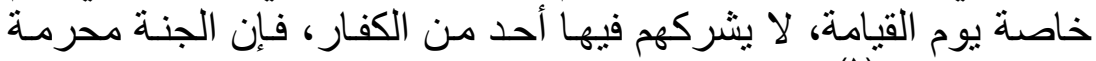

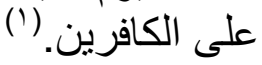
فزينة الله عامة سواء في مـا نزلت فيه الآيـة وهى الثياب الظـاهرة،

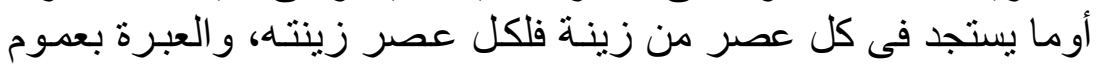

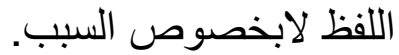

\section{ثانياً: من السنة: الخصن:}

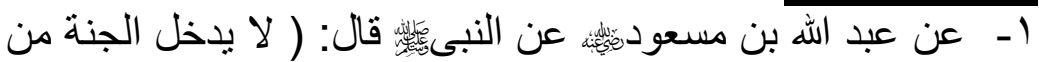

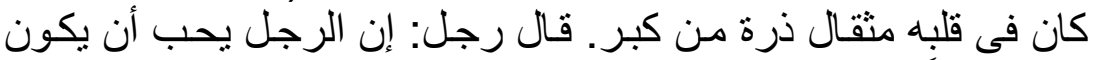

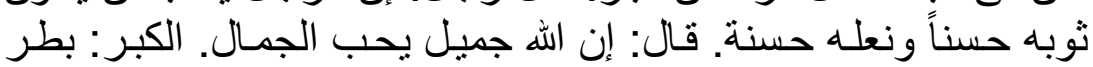
الحق، و غمط الناس). (r)

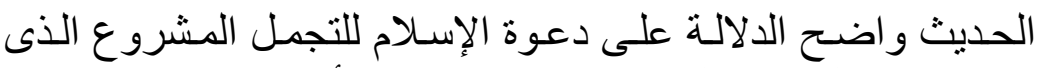

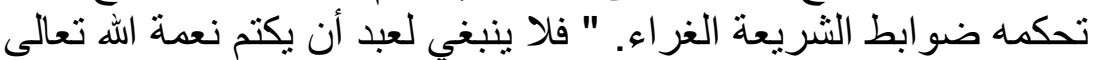

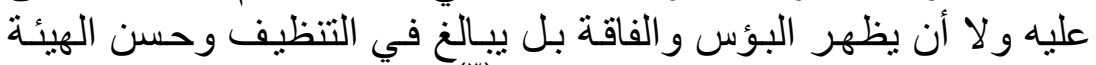

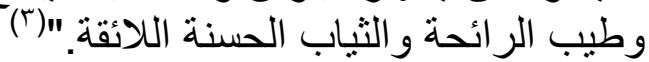

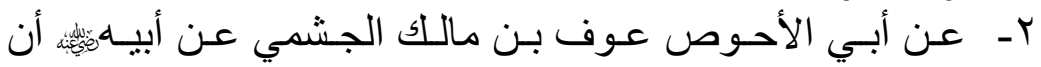

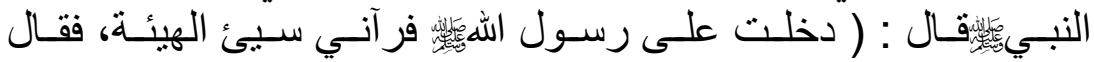

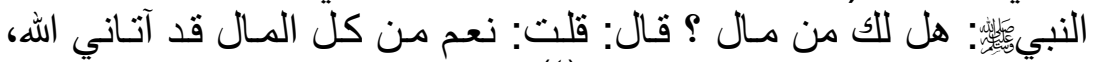

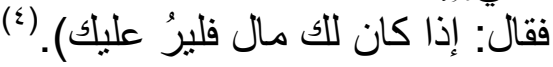

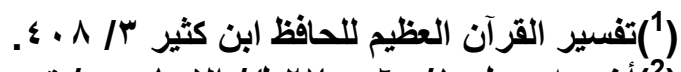

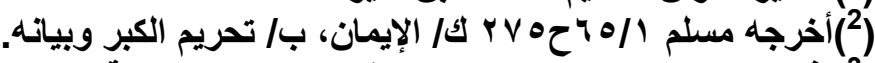

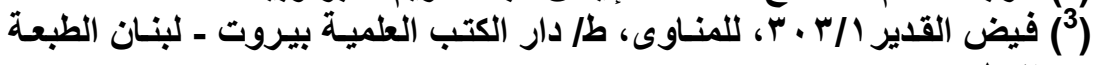

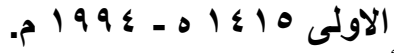

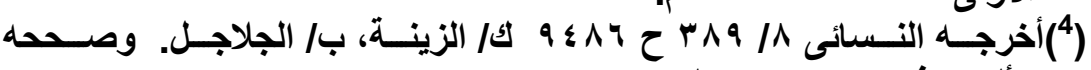

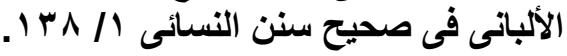




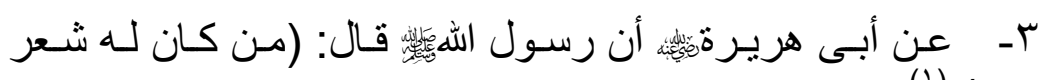

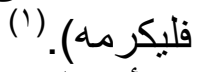
أي فليزينه ولينظفه بالغسل و التدهين و الترجيل و لا يتركه متفرقا فإن إن النئ النظافة وحسن المنظر محبوب. (r)

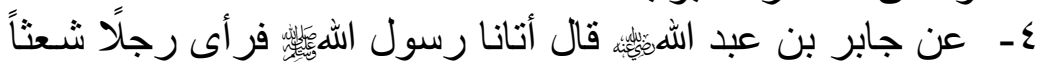

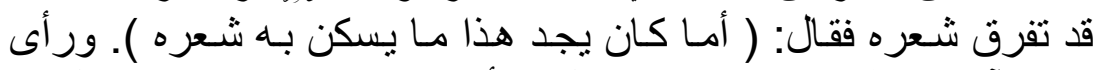

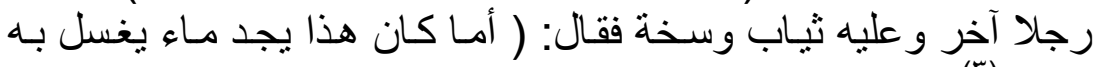

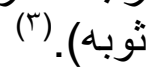

فكل هذه النصوص القرآنيـة والنبويـة المتقدمة تبين حرص الإسـام

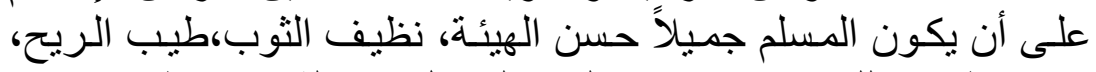

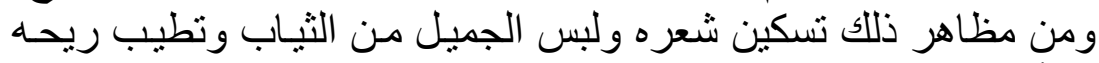

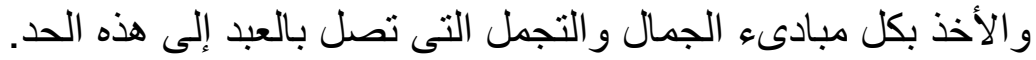

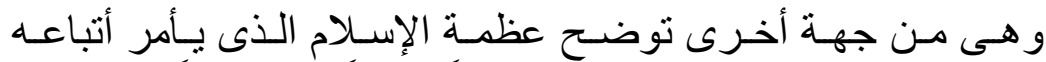

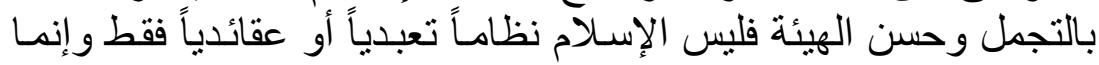

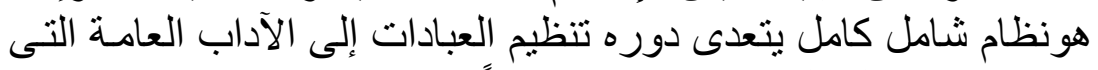

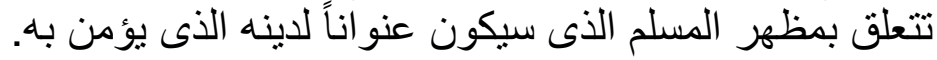

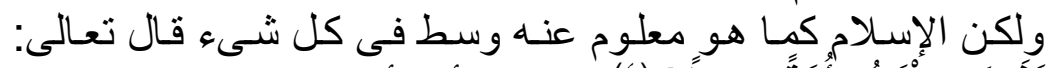

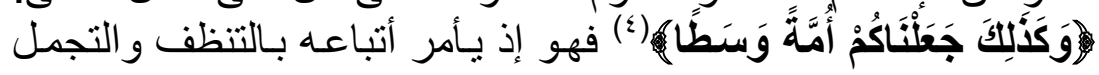

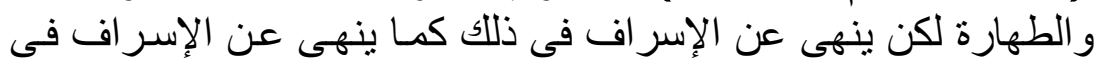
كل شىء؛، وهذاما سوف أبينه فى السطور النالية. المبحث الثثانى: نهي الإسلام عن الإسراف في الترفه و التجمل

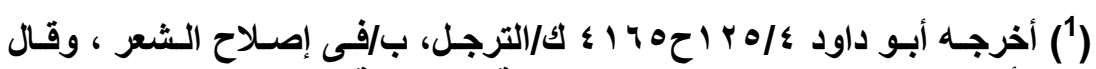

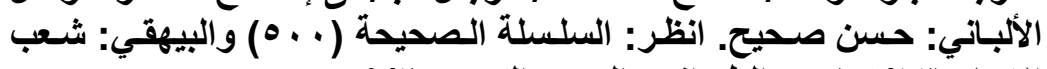

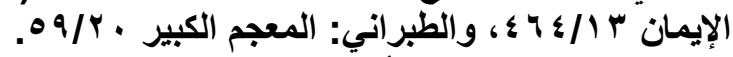

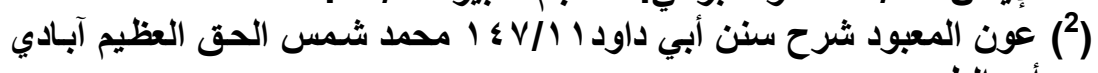

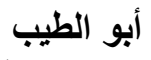
الناشر : دار الكتب العلمية - بيروت.

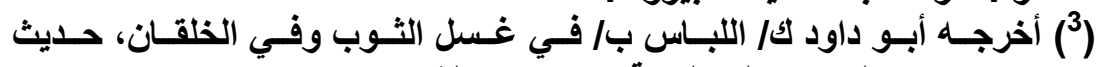

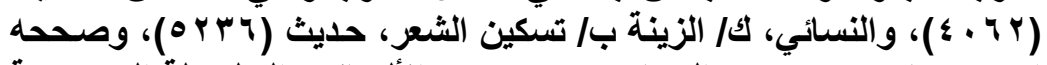

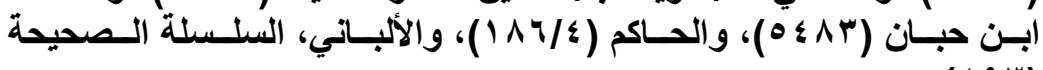




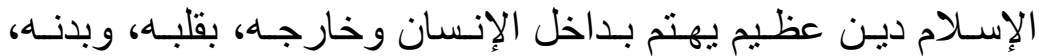

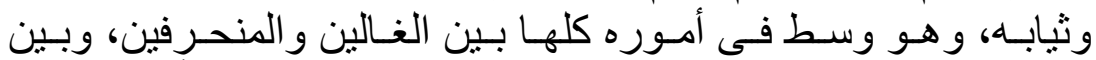

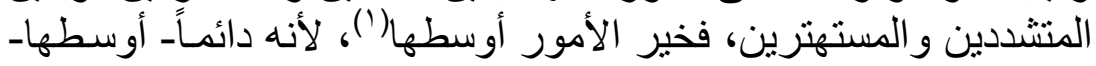
يكون أعدلها و أقومها.

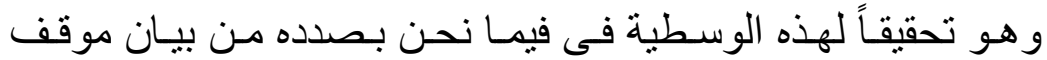

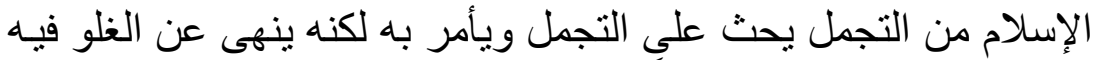

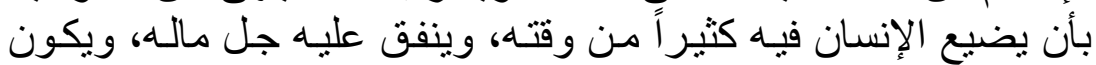

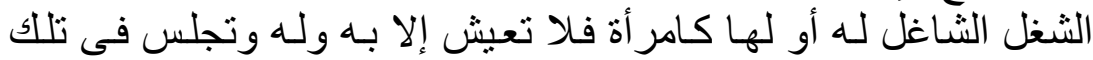

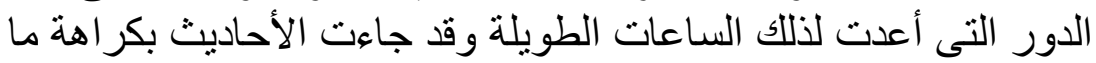

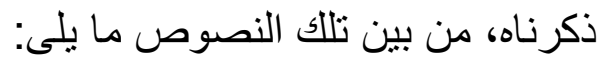

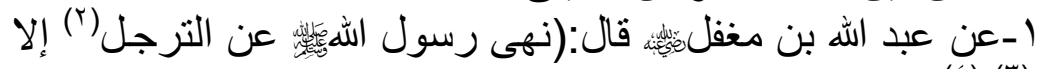
غباًا) (َ)

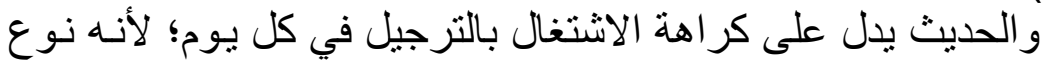

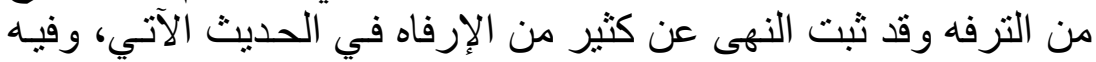

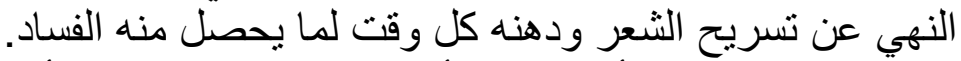

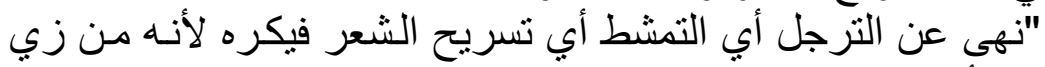
العجم وأهل الدنيا

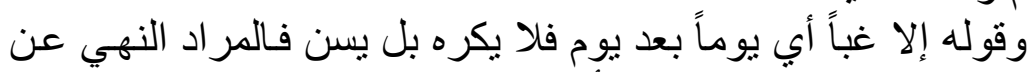

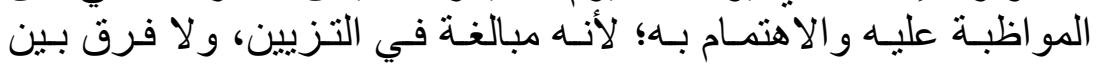

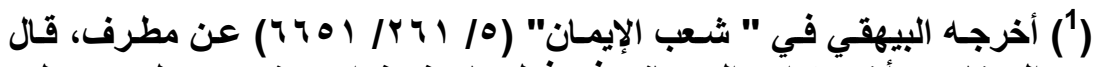

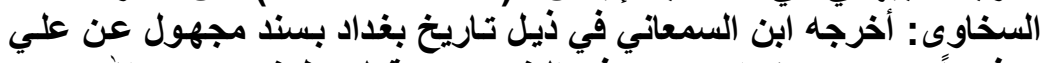

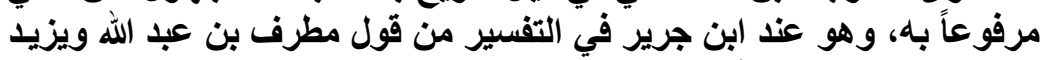

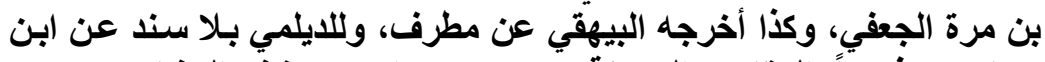

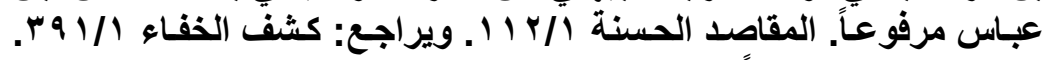
وإسناده صحيح معضلاً.

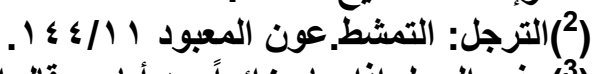

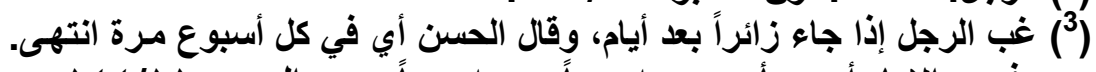

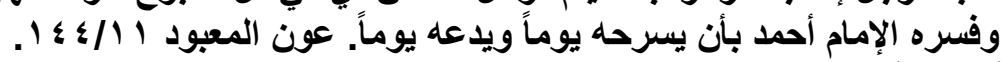

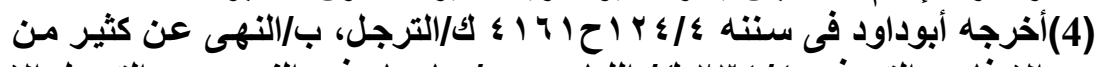

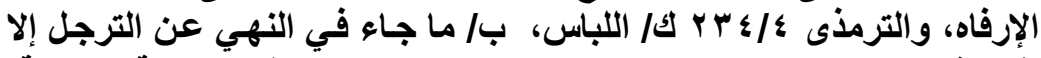

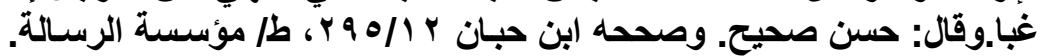

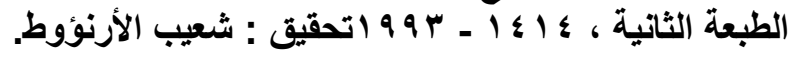
INTH 
الرجل و المر أة لكن الكراهة فيها أخف؛ لأن باب التزيين في حقهن أوسع (برى

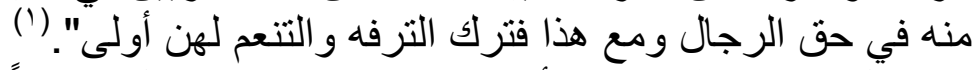

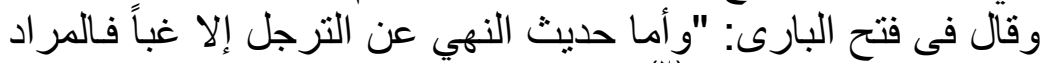

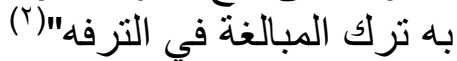

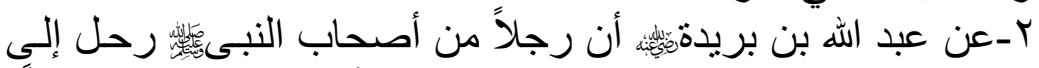

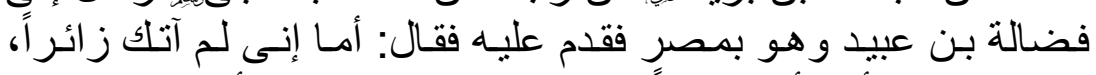

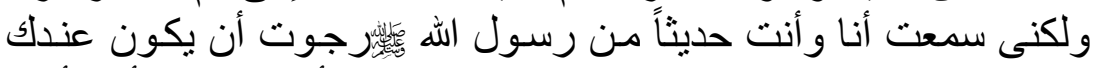

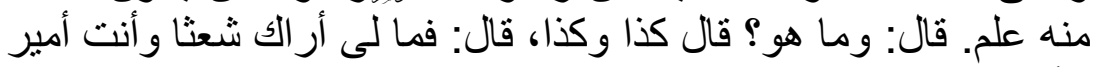

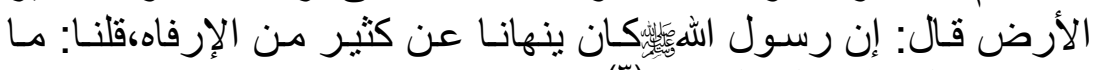

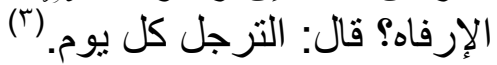

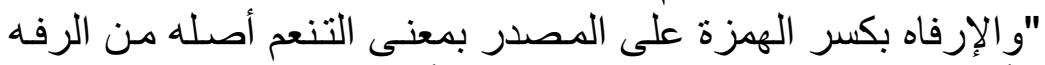

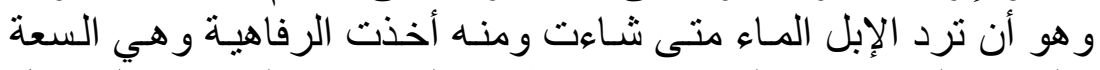

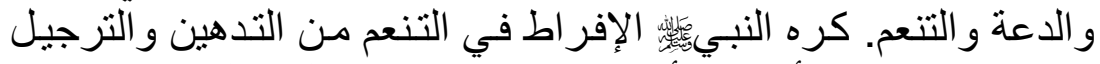

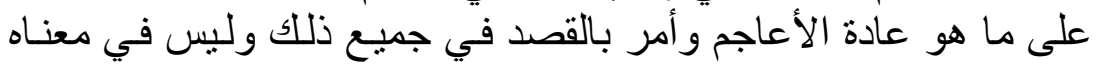
الطهارة والنظافة فإن النظافة من الدادين قال الحافظ: القيد بالكثير في الحديث إنثارة الإنى إلى أن الوسط المعتدل

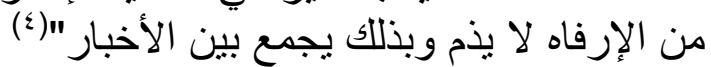

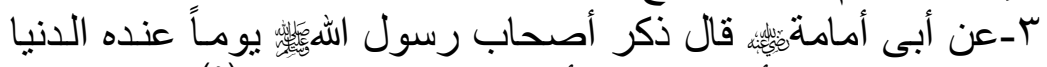

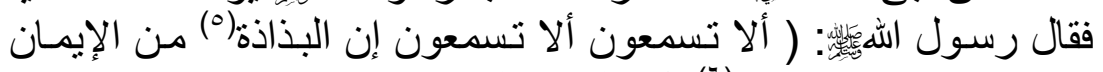

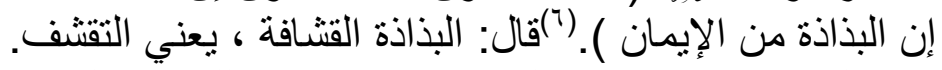

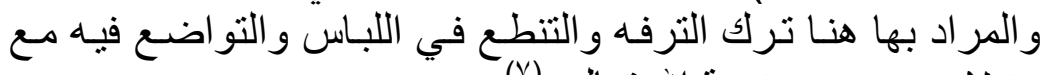
القدرة لا بسبب جحد نعمة الله تعالى. (v)

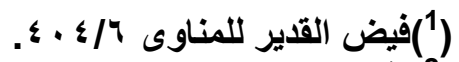

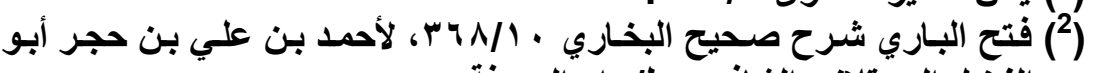

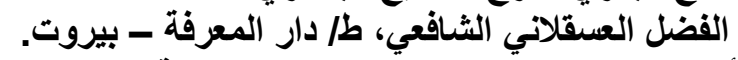

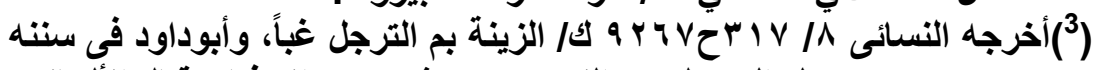

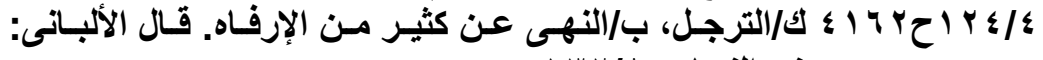

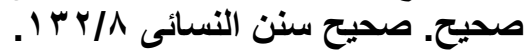
(ال)

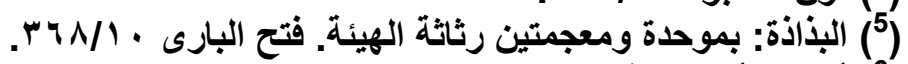

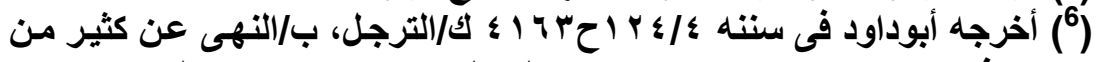

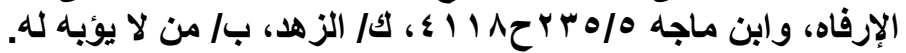

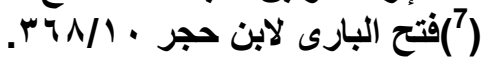




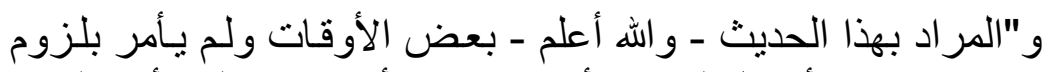

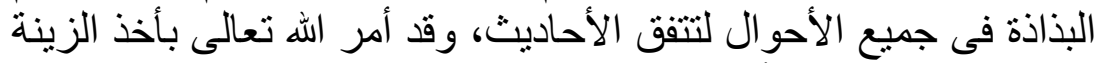

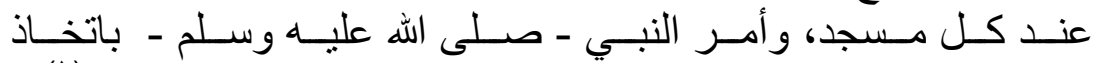

الطيب،وحسن الهيئة و اللباس فى الجمع وماشكل ذلك من المحافل". (') 


$$
\begin{aligned}
& \text { الفصل الثانى } \\
& \text { الجراحة التجميلية التئية } \\
& \text { ماهيتها - تاريخها - أنو اعها - أسبابها }
\end{aligned}
$$

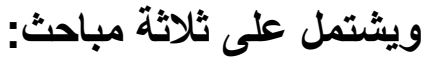

$$
\begin{aligned}
& \text { المبحث الأول: ماهية الجراحة التجميلية، وتاريخها. } \\
& \text { المبحث الثانى: أنواع الجراحة التجميلية، الجئية وأسبابها. } \\
& \text { المبحث الثالث: ضوابط إجراء الجراحة التجمية التجيلية. }
\end{aligned}
$$




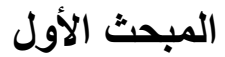 \\ ماهية الجراحة التجميلية، وتاريخها}

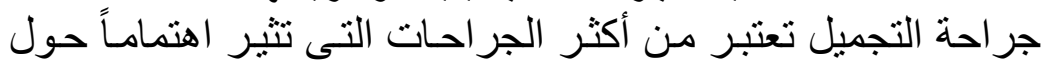

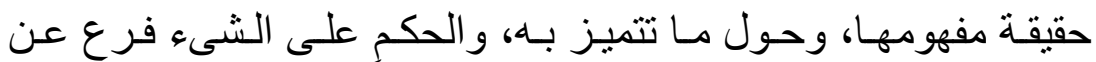

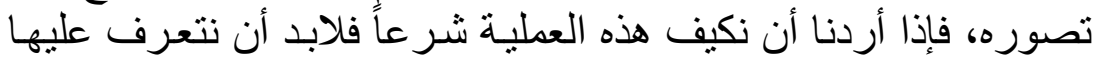

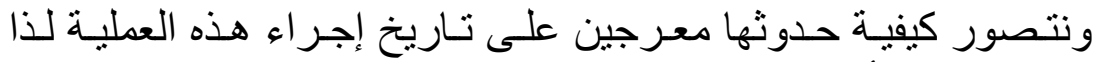
يقتضى المقام أن نقسم هذا المبحث إلى مطلبين: المطلب الأول: ماهية الجراحة التجميلية التهية

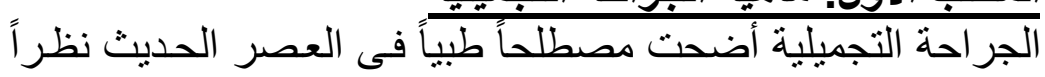

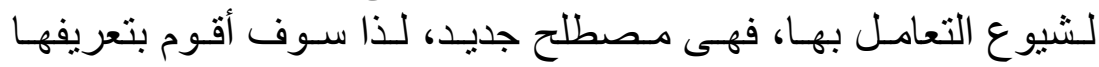
الأول: باعتبار مفر ادتها وما ير اد بها لغة واصطاحاً،

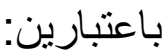

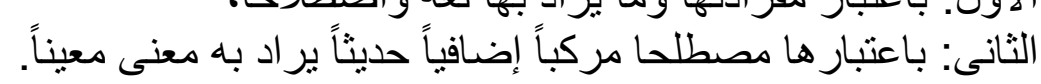
ويشتمل هذ المطلب على فر عين: الفرع الأول: تعريف الجراحة التجميليةباعتبار مفرداتها:

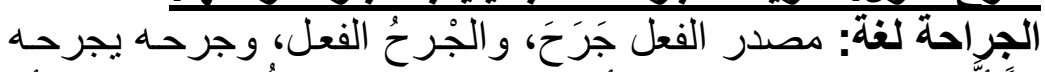

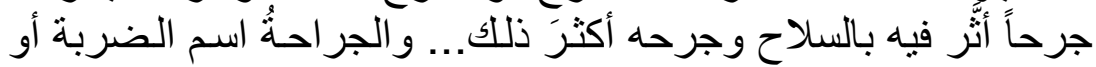

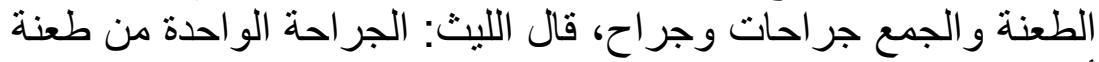

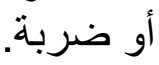

وجرحه بلسانه شتمه، يقال جرح الحاكم الثاهد إذا عثر منه على مـا تسقط به عدالته من كذب وضن وغيره.

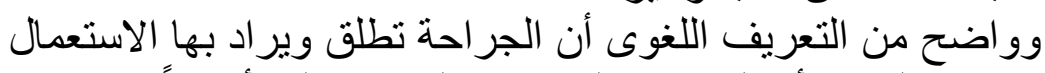

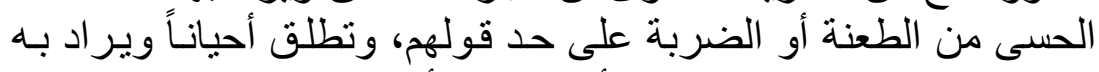

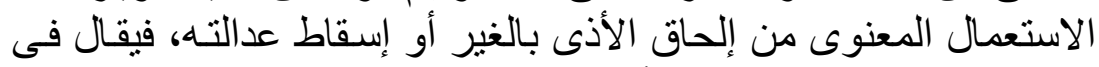

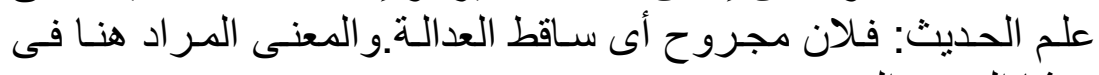

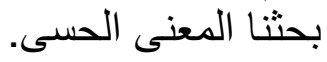

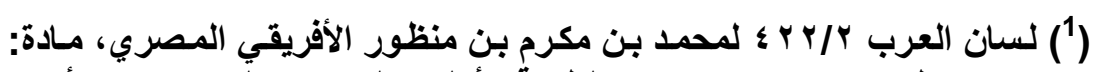

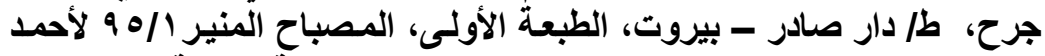

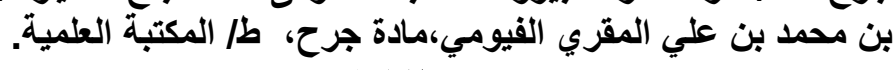
IATV 
عرفتها الموسو اصطلاحاً:

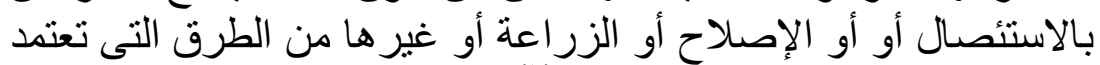

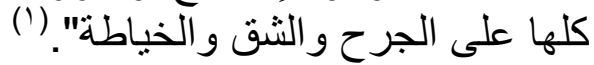

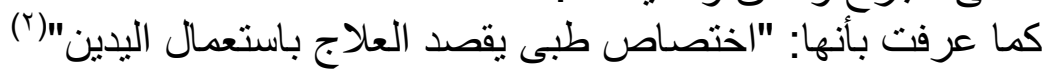

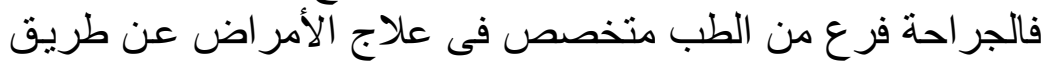

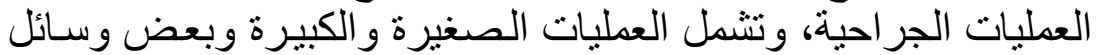

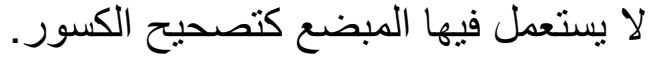

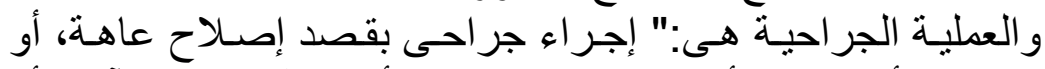

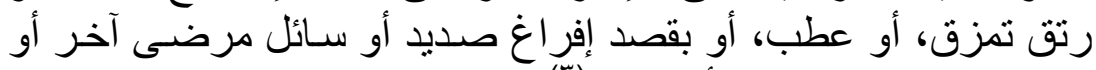

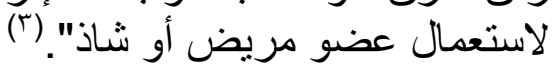

تعريف "التجميلية" لغة:مصدر الفعل جمُل، و الجمـال الحسن يكون

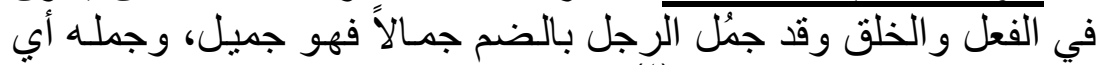

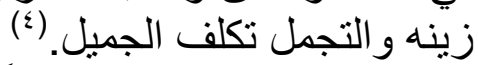
يقال: تجمل أي أظهر جمالاً وتصنع وتحسن، وذلك إذا تكلف الحسن

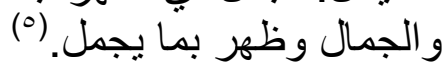
هى "كل عمل من شاحاً: عليه أو الإنقاص منه". (؟)

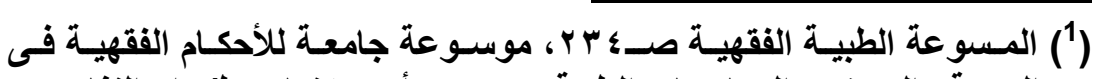
الصحة والمرض والمعارسات الطبية، د. محمد أحمد كنعان. طا دارة دار النفائس.

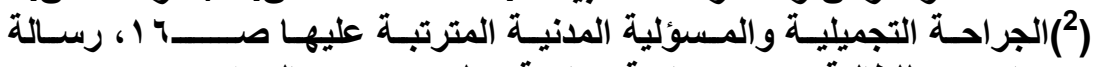

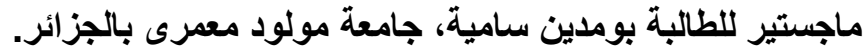

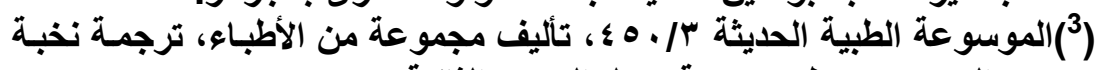

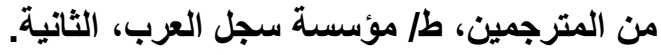

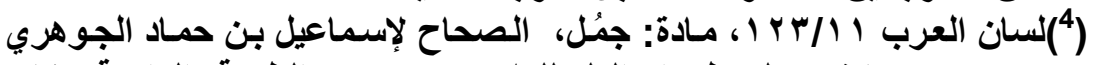
 .199 .

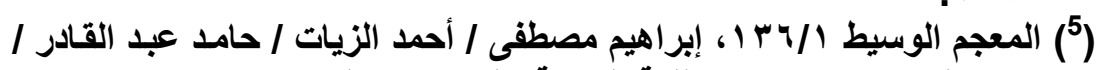

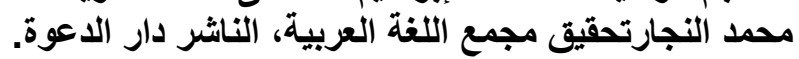

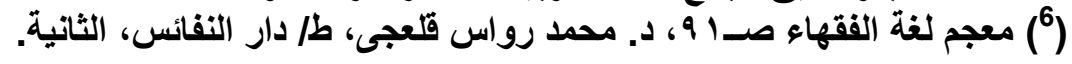
INYA 


\section{الفرع الثانى: تعريف الجراحة التجميلية فقهابًاعتبار هـا مصطلحاً}

تعددت تعريفات الفقهاء المعاصرين و القانو نيين للجر احـة التجميلية

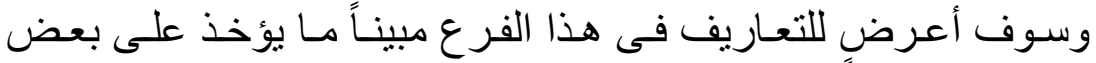

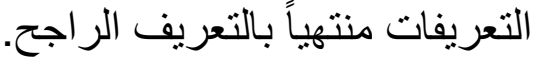

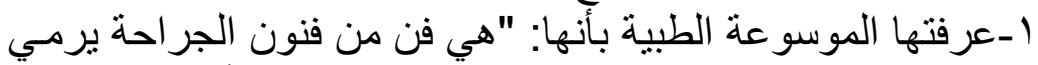
إلى تصحيح التشوهات الخلقية مثل: قلع السن الزئ الز ائدة، أو تعديل شكل

الأعضاء المشوهة، ". (') النشوهات

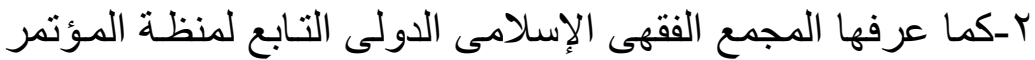

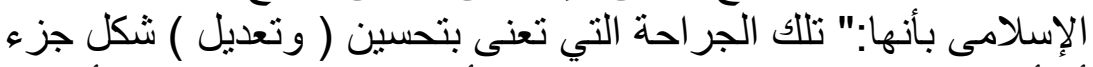

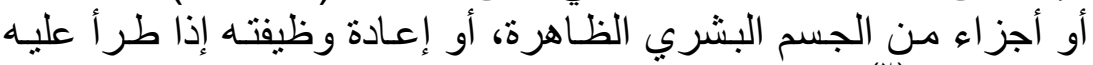

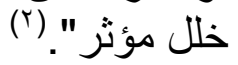
بـتعريف آخر للجر احـة الطبيـة: "إجر اء طبي جر احي يستهدف تحسين شكل العضو الظاهر". (")

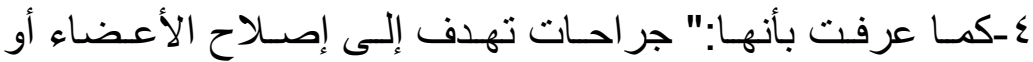

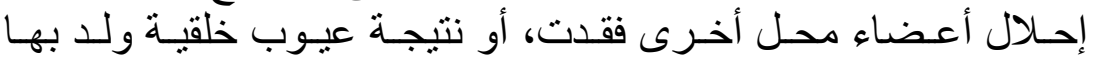
الإنسان". (๕) (1)

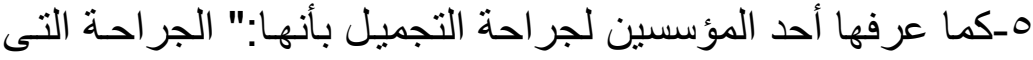

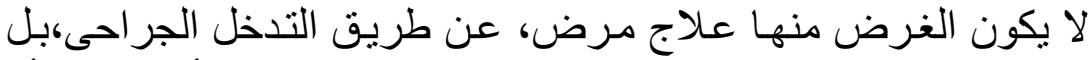

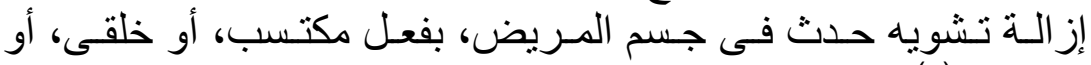

وظيفى". (ن)

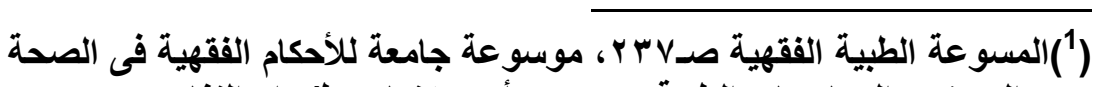

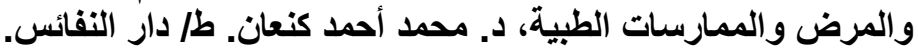

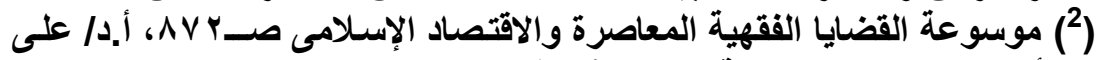

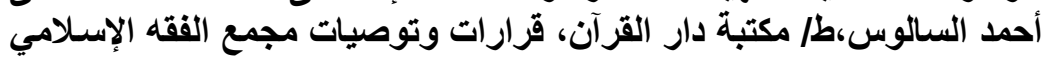

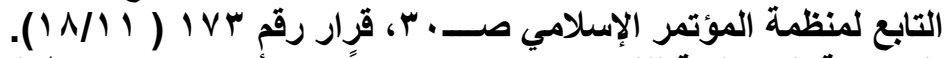

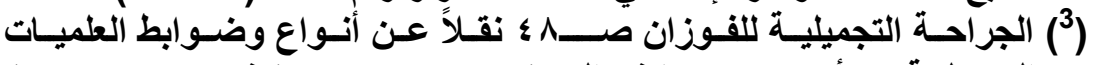

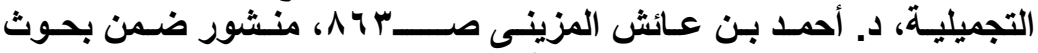

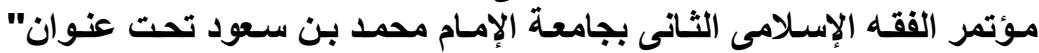

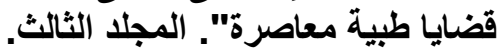

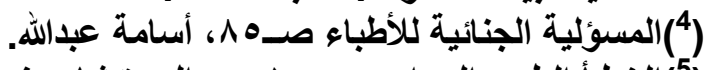

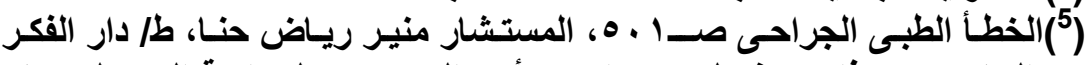

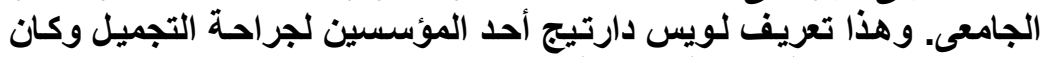
يشغل مدير الجمعية العلمية لجراحة التجميل. lNrq 
و التعريفات السابقة متقاربة المدلول ظاهرة المعنى وهي تدل على أن أن

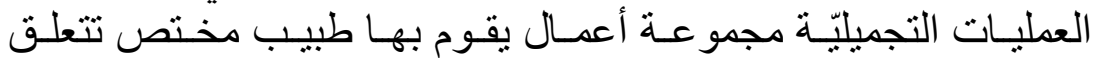

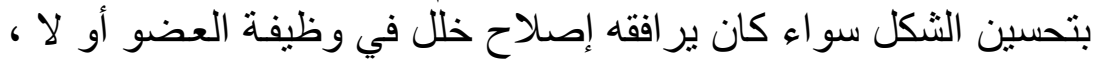

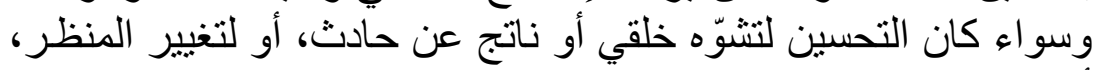

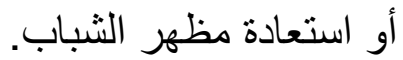

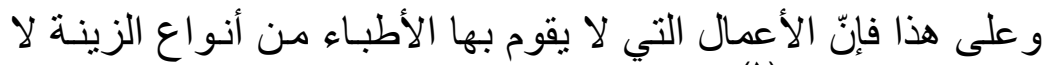

تدخل في هذا البحث. (1)

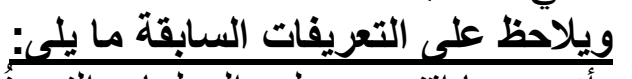

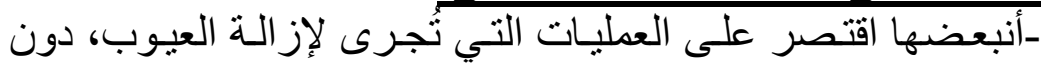
التي تهدف لزيادة الحسن في عضو صحئ صحيح.

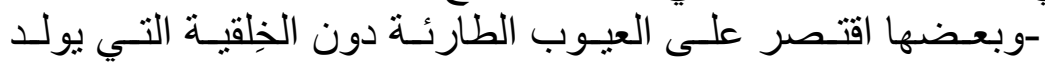

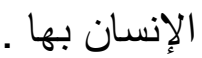
-وبعضها أدخل العمليات التقويمية التي بر اد بها إعادة وظيفة العضو ، ولو لم تتعلق بتحسين الثكل.

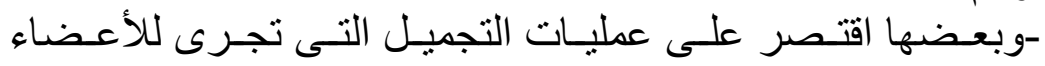
الظاهرة دون تلك التى تجرى تحت الثياب كعمليات نرقيع وتجميل الجلد

\section{التعريف الراجح}

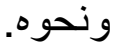

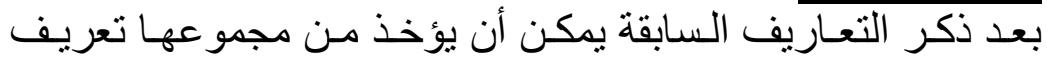

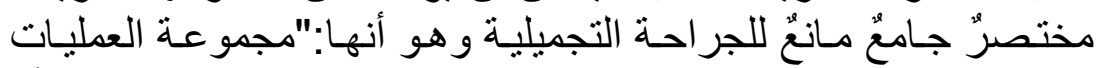

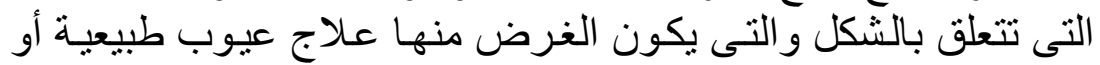
مكتسبة فى ظاهر الجسم البشرى تؤثر فى القيمة الثخصية والثي واجتماعية للفرد"'(r) مكتبة في

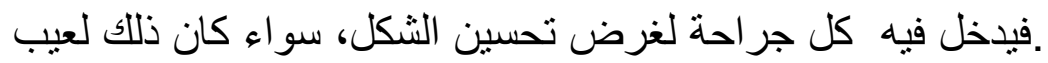

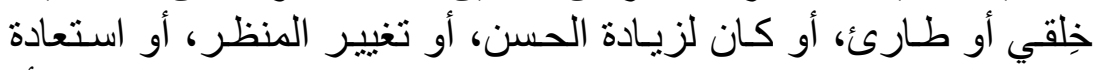

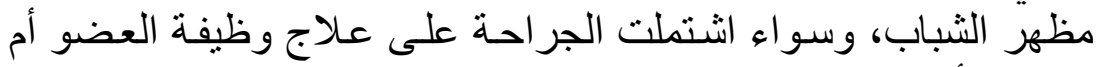
لا لا و الله أعلم.

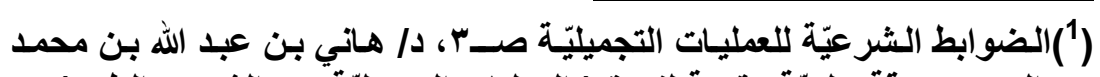

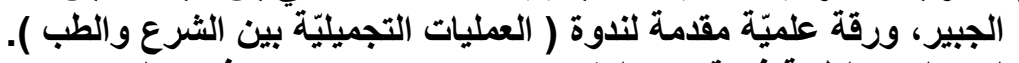

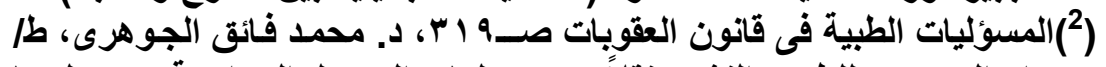

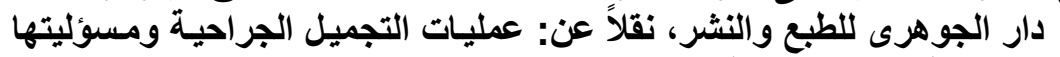

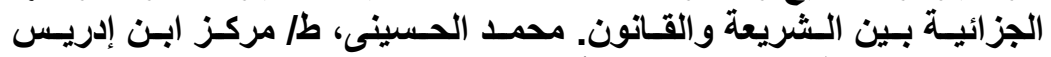
للاراسات الفقهية. والتعريف في الأصل للاكتور لويس دارتيج خبير التجميل. lᄉr. 


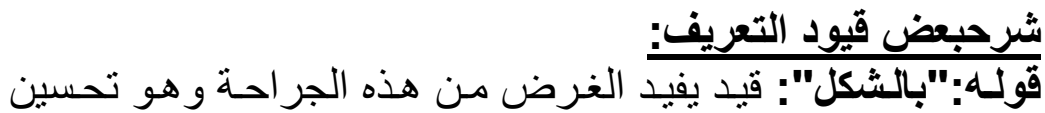
الشكل ويخرج ما كان الغرضئ فئه منه علاجياً.

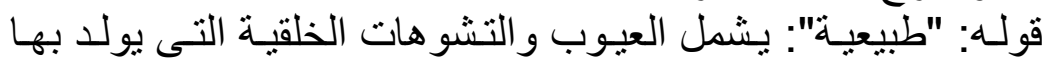

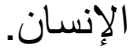
قوله: "أو مكتسبة": يشمل العيوب الناثئُة من الآفـات المرضية التى الإنى

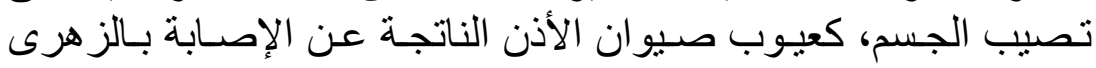

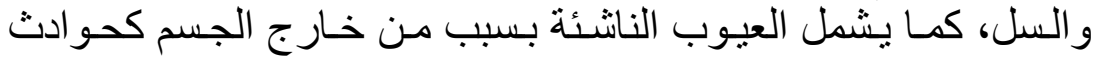

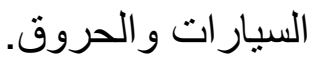

قوله: " ظاهر الجسم": قيد يدل على اختصاص الجراحة التجميلية

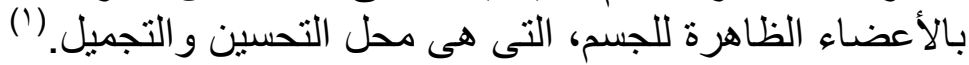

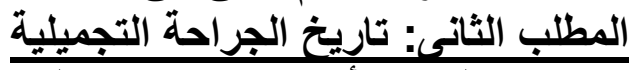

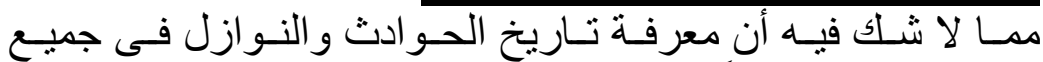

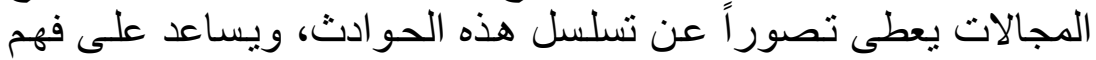

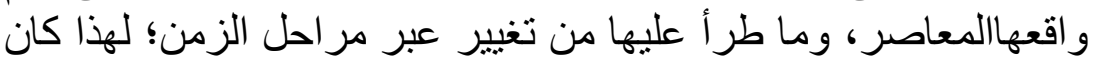

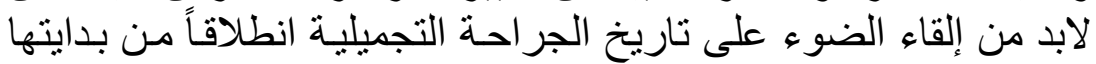

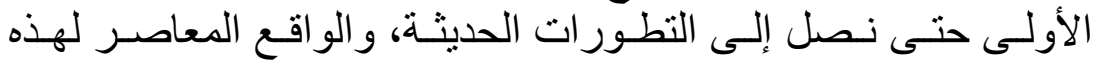

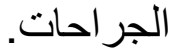

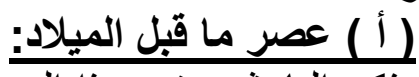

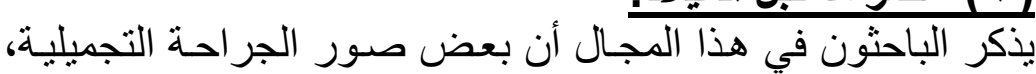

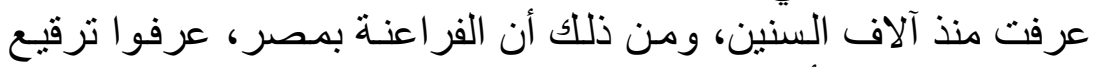

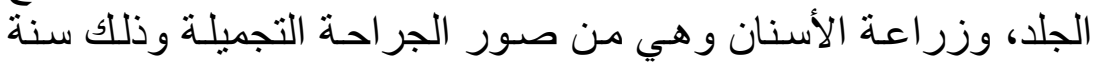

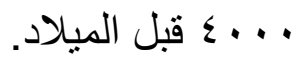

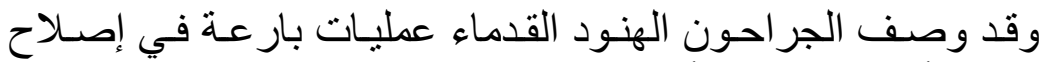

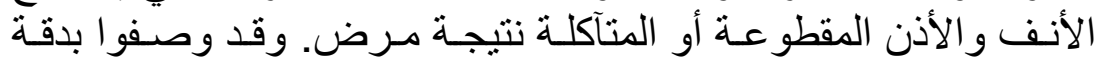

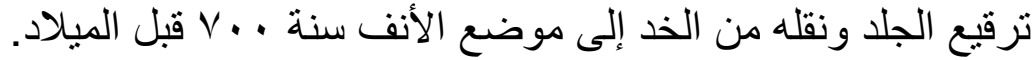

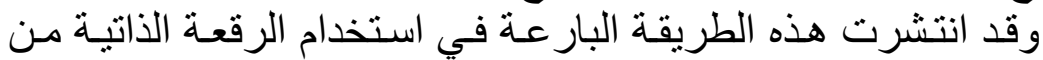

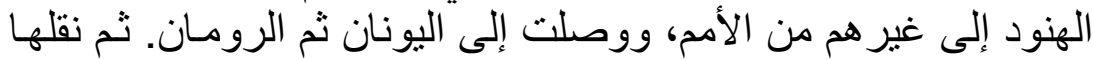

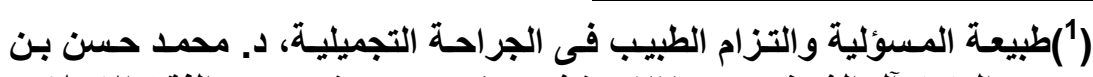

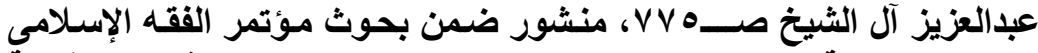

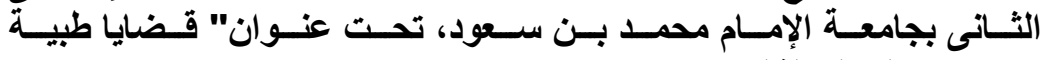




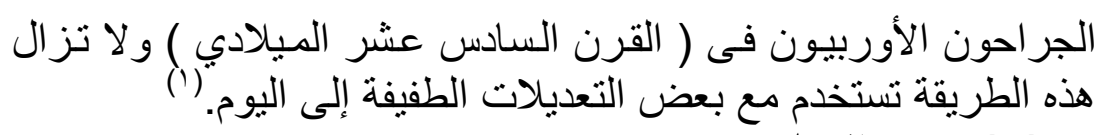
(ب) عصر الإسلاد:

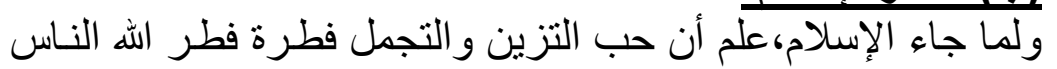

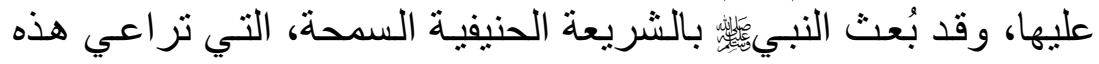

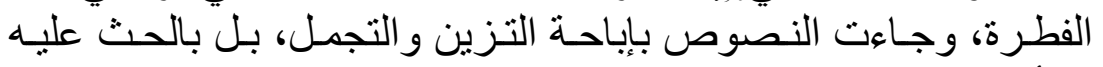

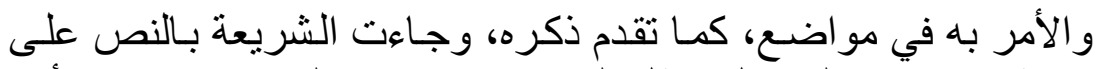

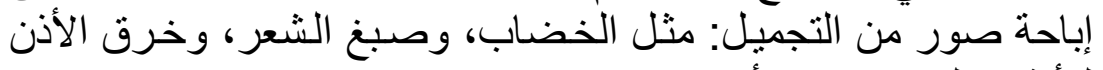

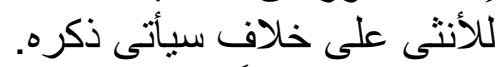

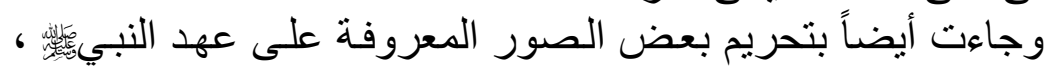

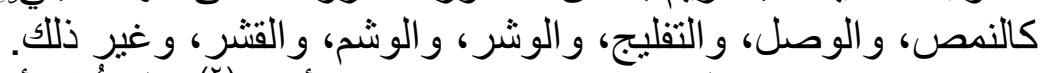

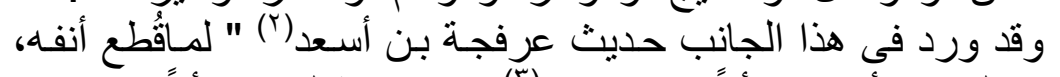

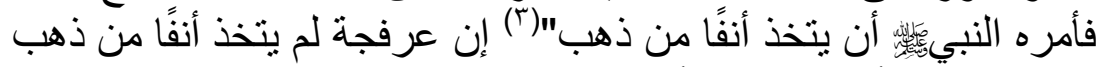

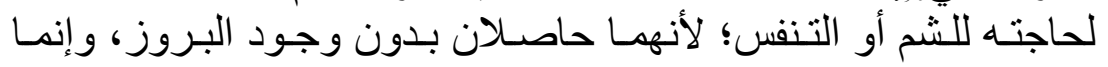

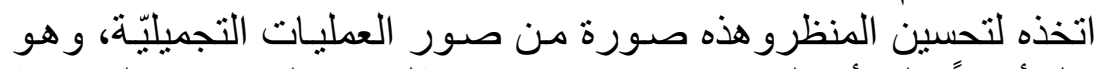

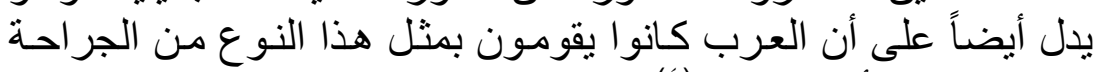

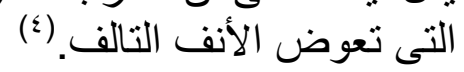
ثم كان لعلماء المسلمين بعد ذللك أثر ومساهمة في هذا المجال، ومن

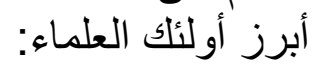

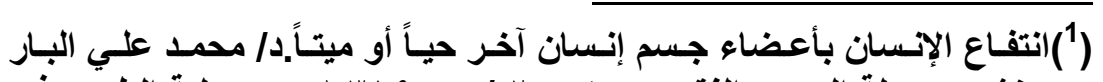

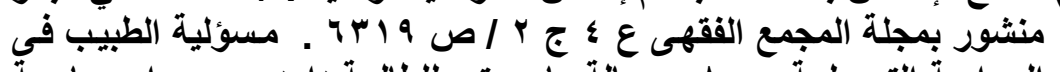

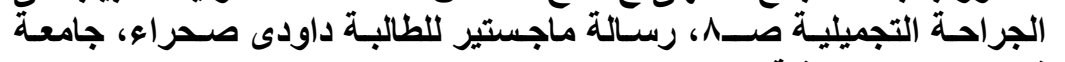
قاصدى مبراح ورقلة بالجزائر.

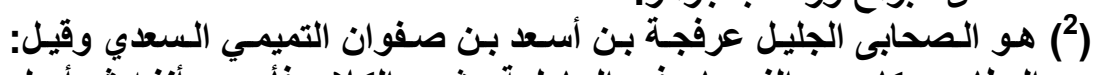

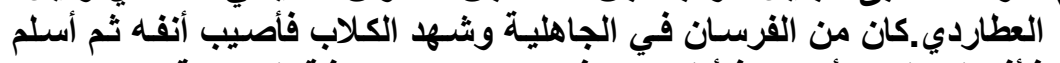

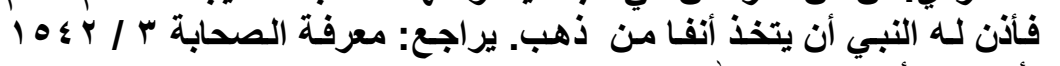

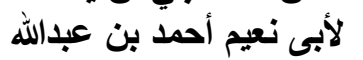

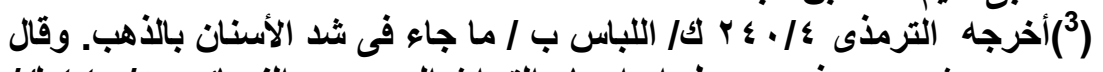

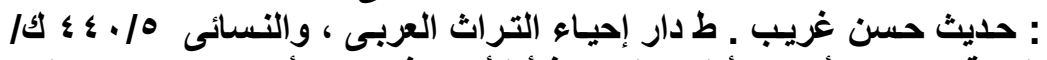

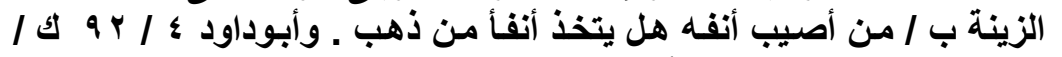
الالباس ب/ ماجاء في ربط الأسنان بالذهب.

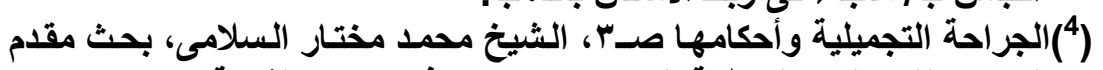
لمجمع الفقه التتبع لمنظمة المؤتمر الإسلامى فى دورته الثامنة عثرة. INTr 


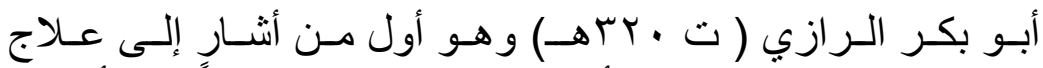

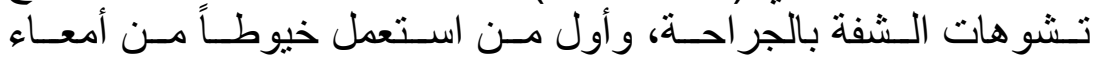

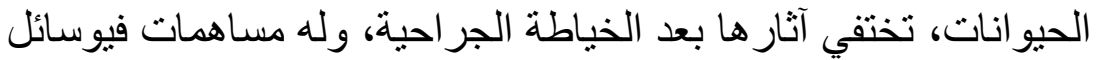

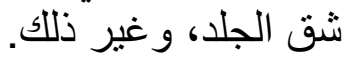

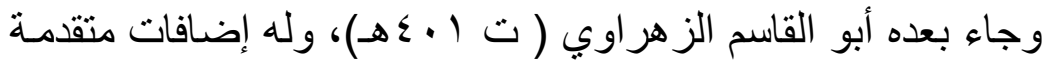

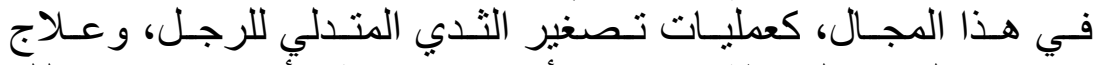

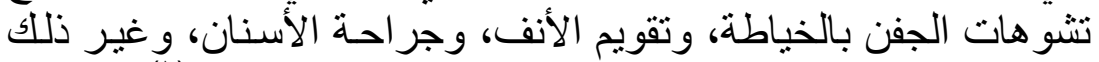

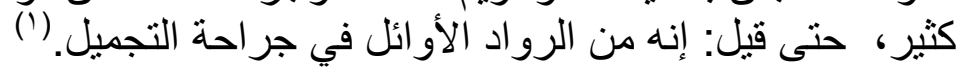

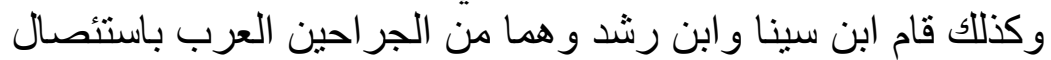

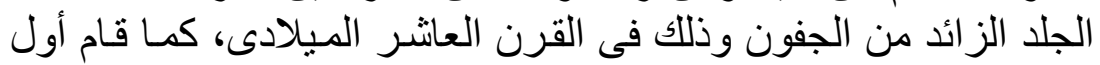

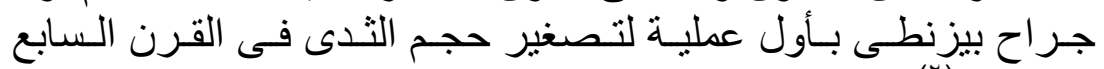

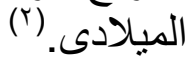

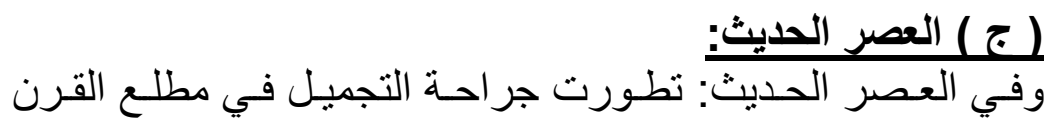

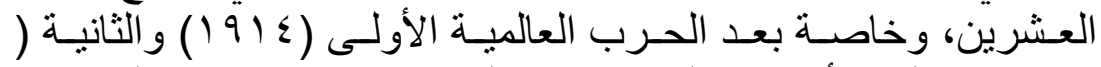

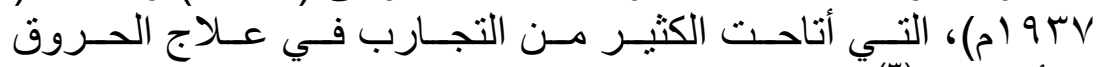
و الأصسابات. (r)

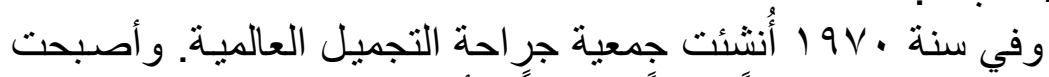

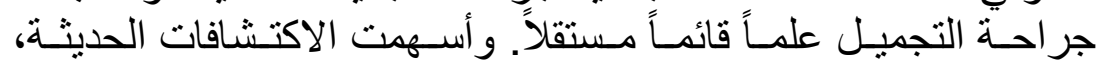

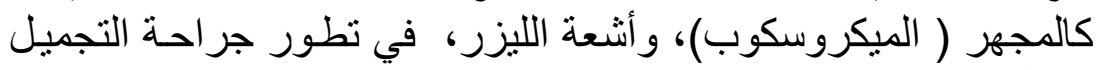

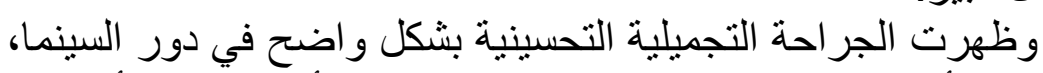

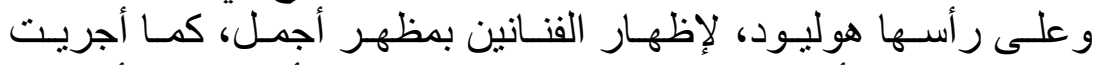
عمليات تقويم الأنف المعقوف لليهود لإفهود النـازحين من ألمانيـا إلى ألى أمريكا، لتسهيل اندماجهم في المجتمع.

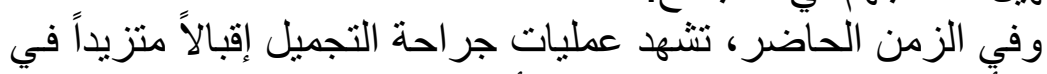

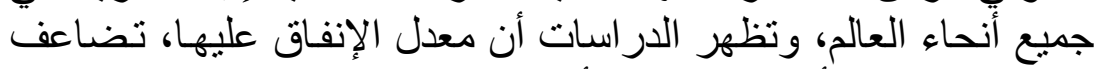
في عشر سنوات أكثر من ثمانية أضعاف، وبلغ عداء العدان العمليات التحسينية

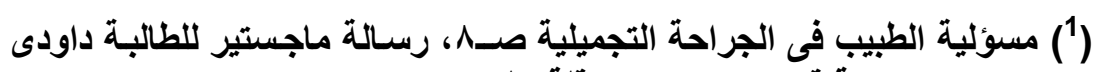

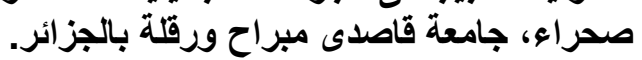

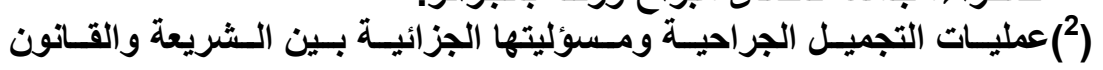
صـ

(3) (الغطأ الطبى الجراحى صــ 11 ( 11. 


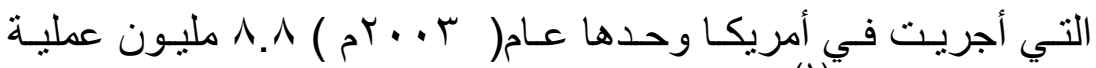
جر آحية تحسينية." (1)

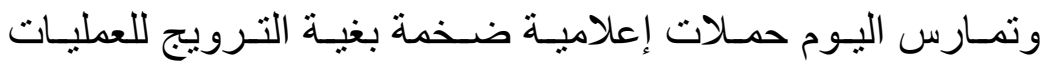

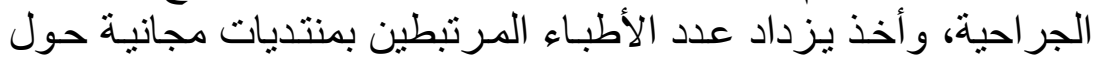

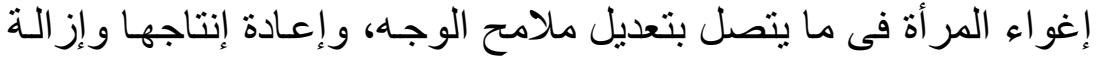

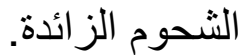

و عدد الأطباء الذين يمارسون العمليات التجميلية مع افتقار هم للخبرة

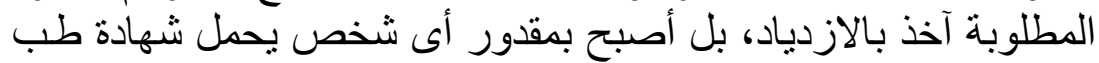

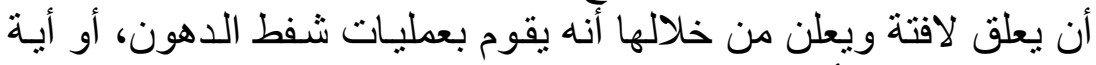

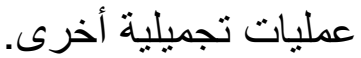
وينفق فى بريطانيا على العمليات التجميلية أكثر من مليونى باوند

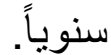

وبحس الجمعية الأمريكية لجر احة التجميل فإن ( . . . . بr ) معلية

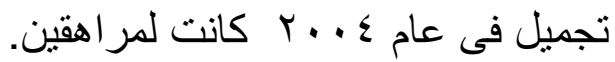
وفى عالمنا العربى لا نجد فيما بين أيدينا إحصائيات أو بيانات تهين أنشير

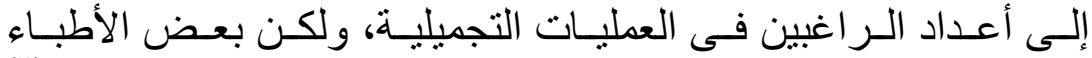

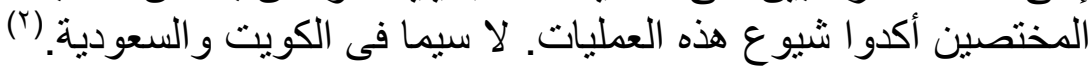

\section{أنواع الجراحة الثاني التجميلية، وأسبابها،}

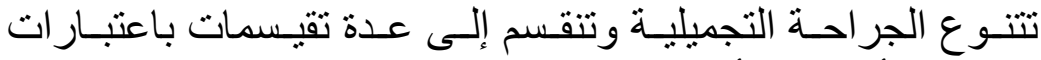

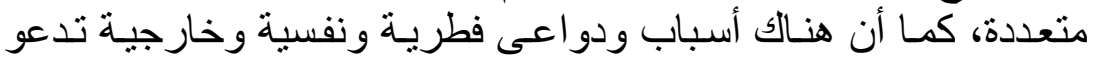

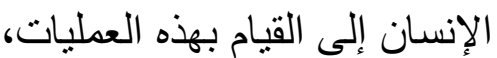

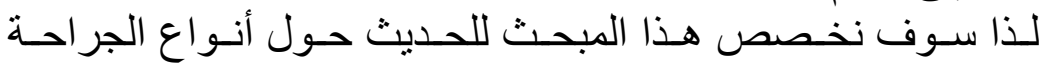
التجميلية وأسبابها، وسيثتنمل هذا المبحث الخد على مطلبين:

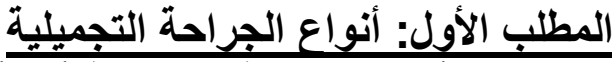

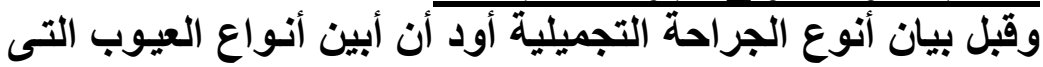

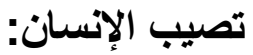

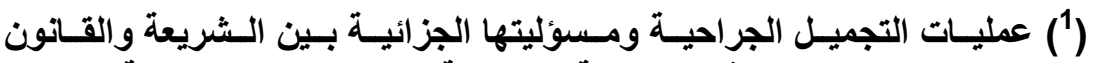

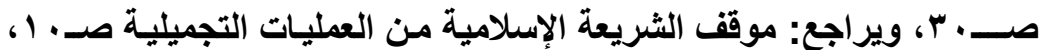
الباحثة إلهام عبدالله باجنيا.

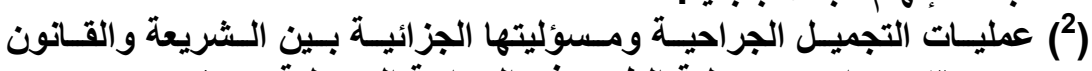

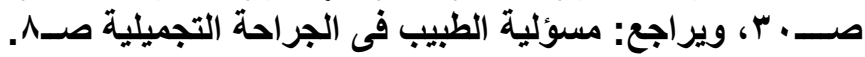


العيوب التى تستدعيها العمليات التجميلية نو عان:

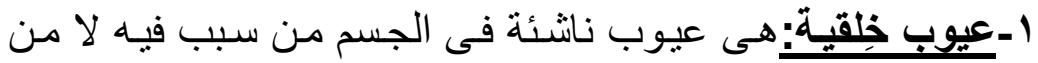

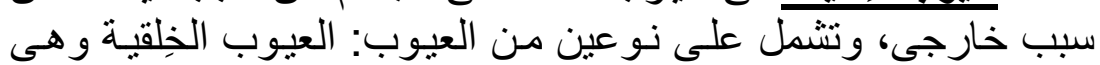

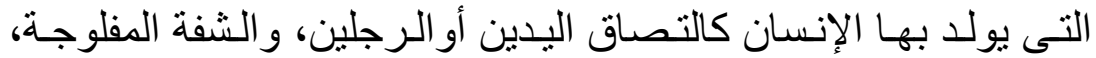

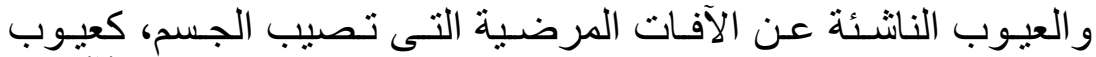

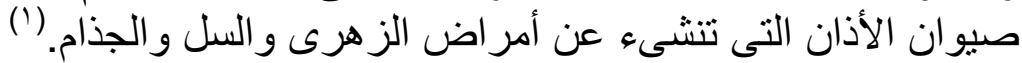

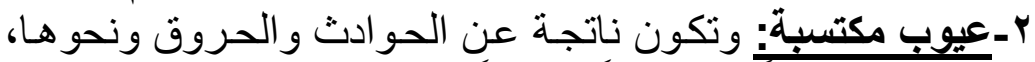

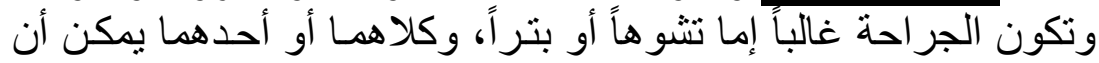

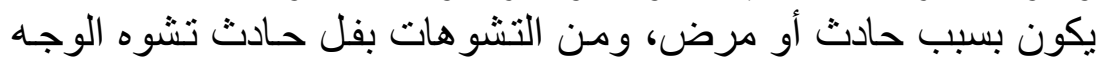

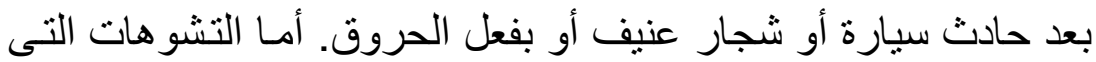

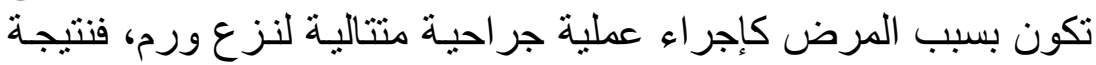

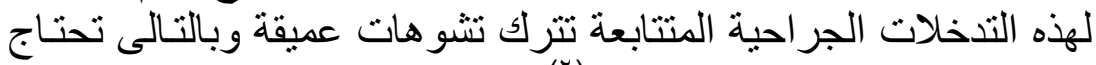

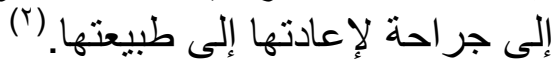
تنقسم الجراحة التجميلية باعتبار أهميتها وحاجـة الإنسان إليها إلى إلى

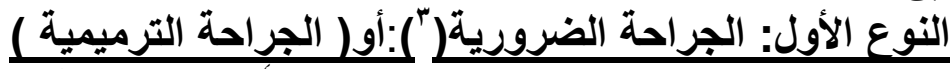

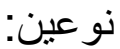

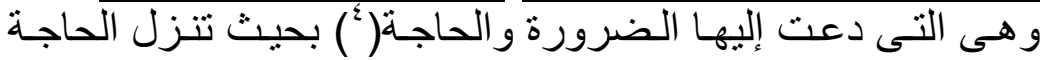

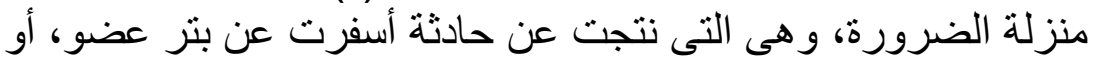

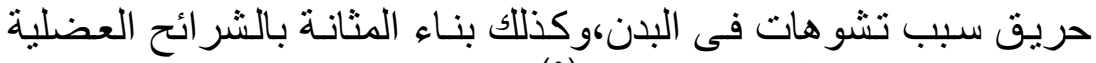

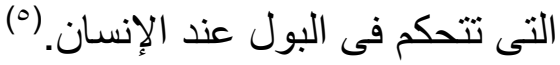

(1) مسؤلية الطبيب في الجراحة التجميلية صـو، ، لاودى صحراء.

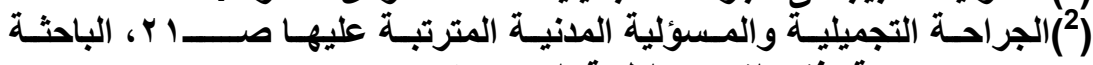

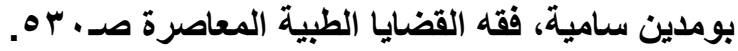

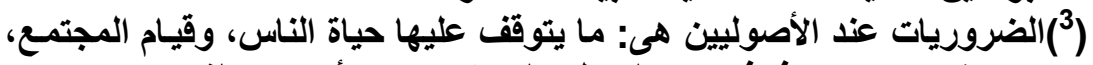

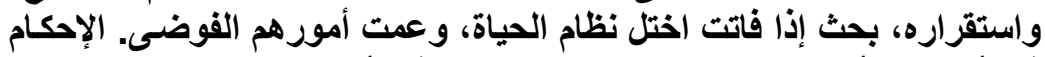

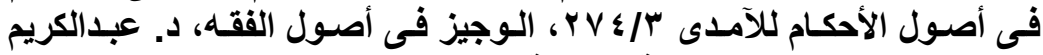

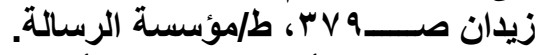

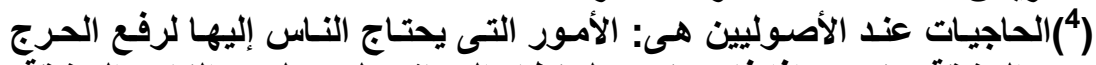

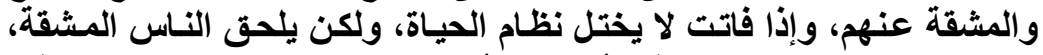

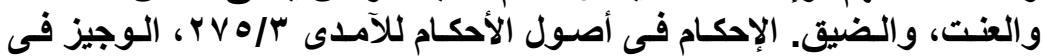

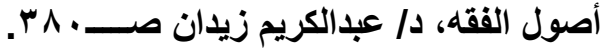

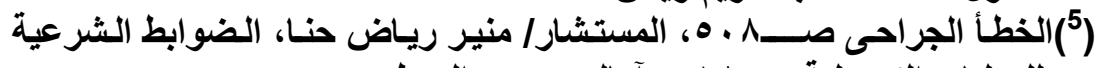
للعمليات التجميلية صد 1 ا أد. دآمال يس عبدار/المعطى. into 
و هذا النوع من الجر احة يصـاب المريض بـأذى وحرج ومشقة إذا

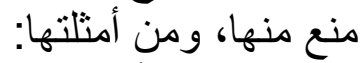

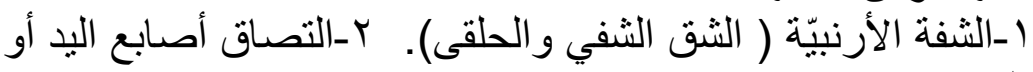
ع -المبال التحتاني. الرجل. ه-إز الة الوشم و الوحمات و الندبات. ج- إز الة شعر الثارب واللحية عند النساء.

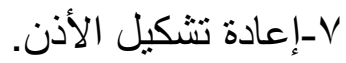

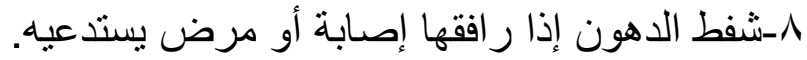

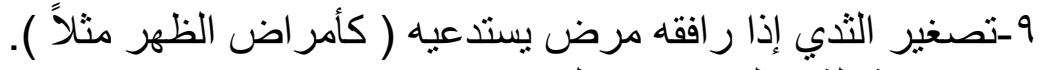
• أ-زر اعة الثذي لمن استؤصل منها.

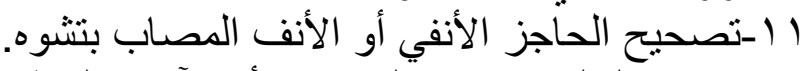

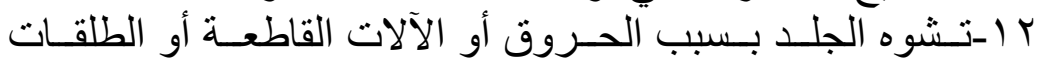

با أتصحيح كسور الوجهاه ( بسبب الحوادث مثنلاً ).

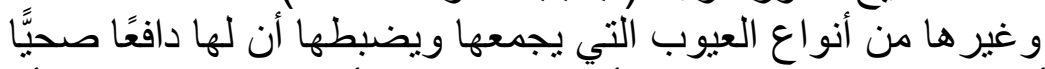

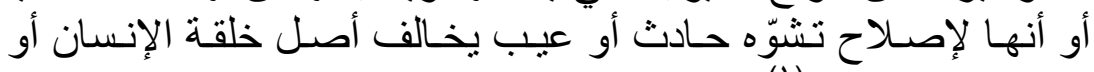

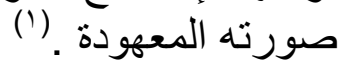

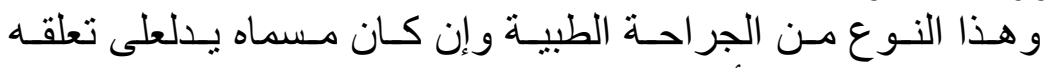

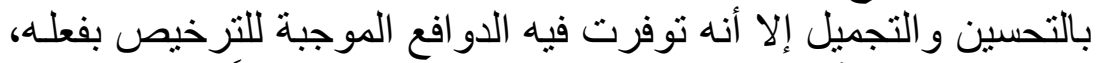

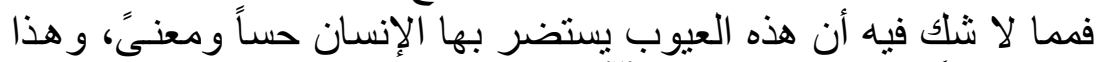

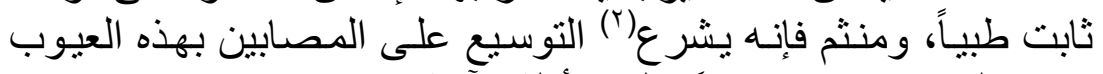

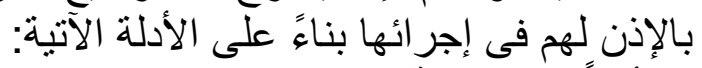
أولاً: من السنئة

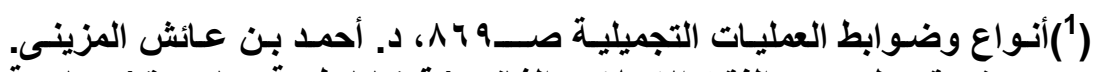

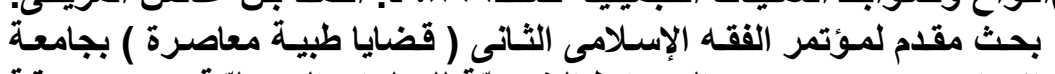

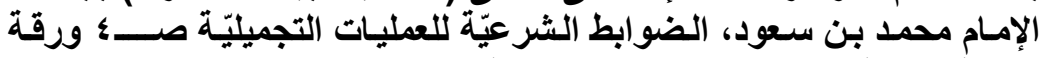

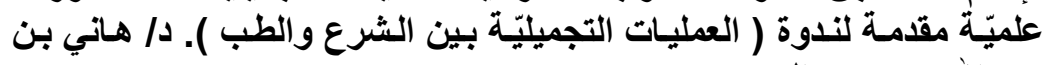

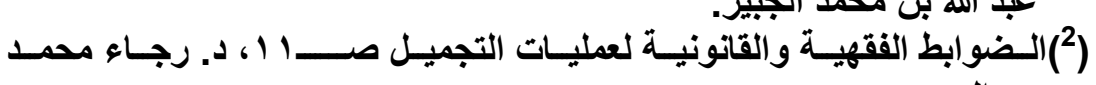




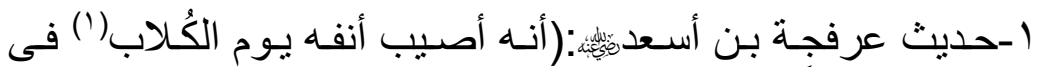

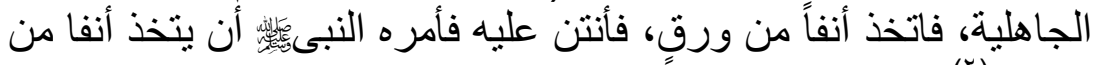
ذهب). (الجان) وجه الدلالة: حيث بين الحديث مشروعية معالجـة المرض المشوه

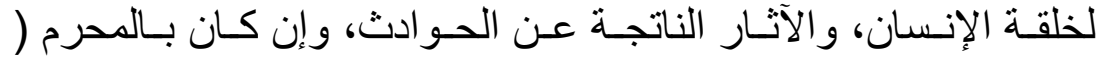
استعمال الذهب ) للضرورة الموجبة لإنان لاستعماله.

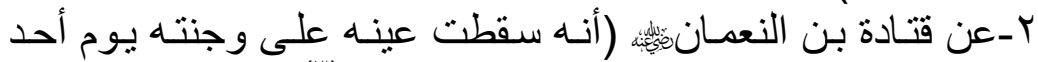

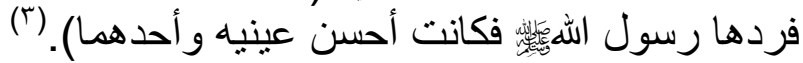

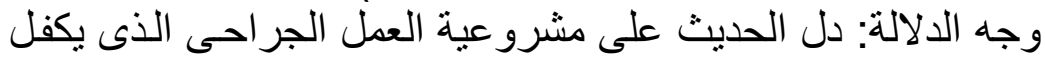

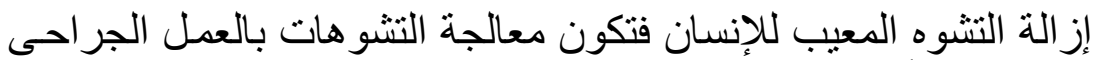

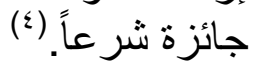

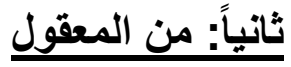

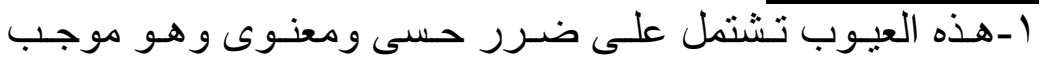

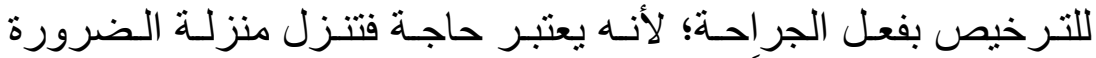

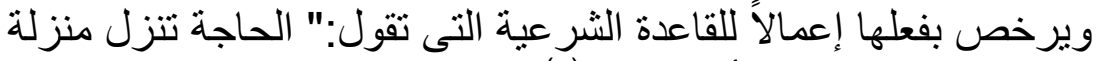

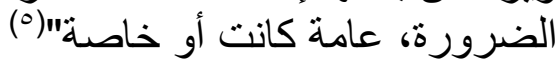

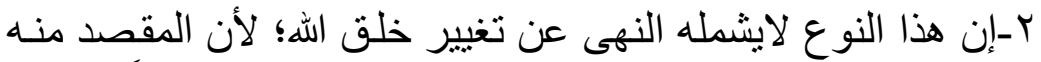

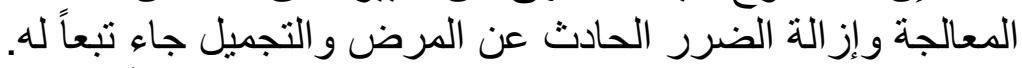

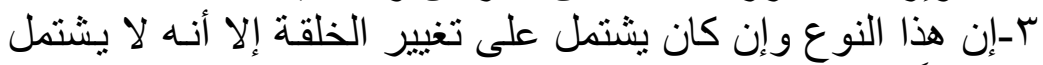

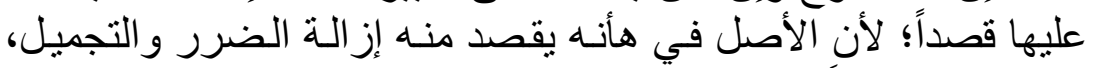
و الحسن جاء تبعاً له.

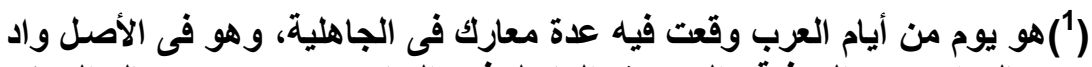

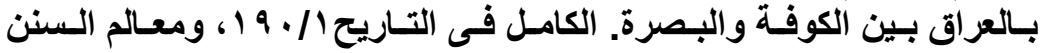

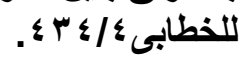

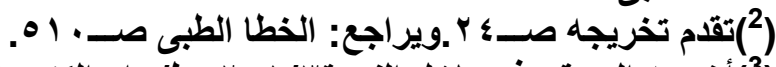

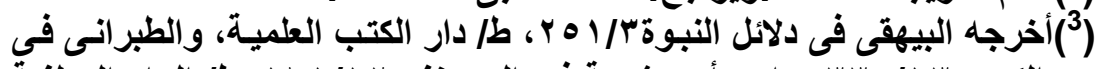

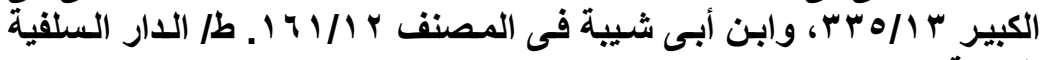
الهندية. - (الكير

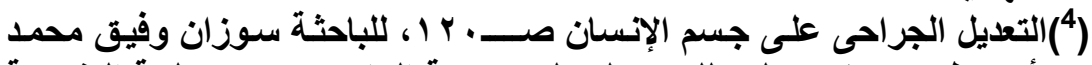

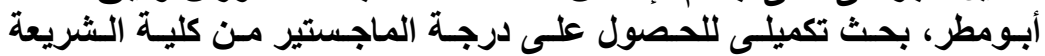

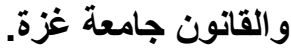

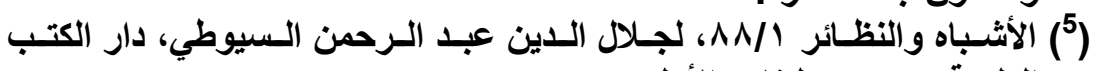


ـ-إن إز الة التشوهات و العيوب الطارئة لا يمكن أن يصدق عليه أنهـ

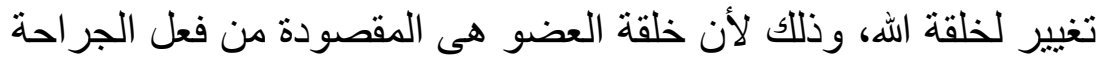

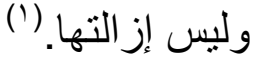

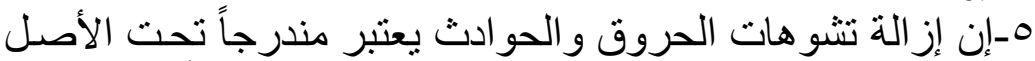

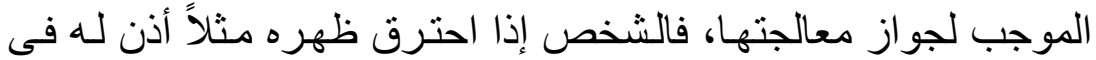

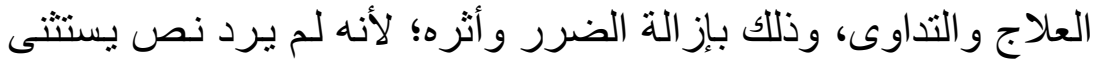

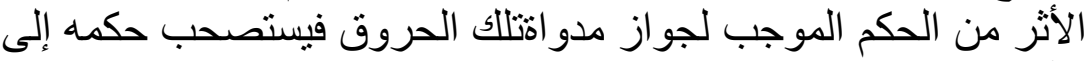
الآثار ، ويؤذن لهن اله بإز التها.

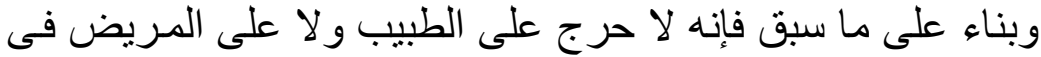

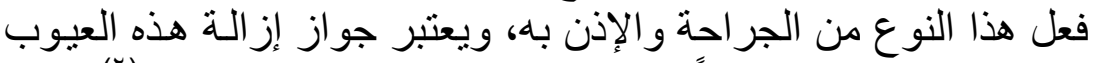

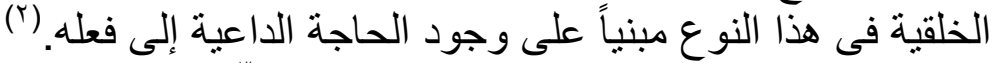

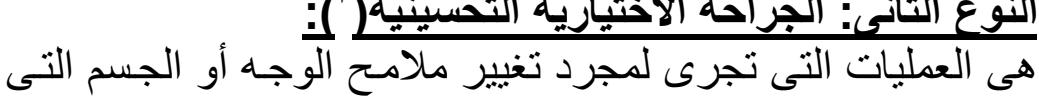

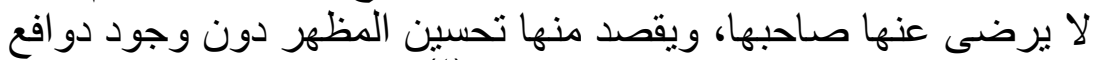

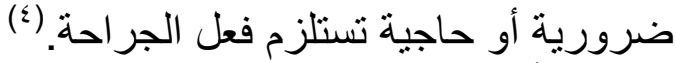
ومن أمثلة هذه العمليات:

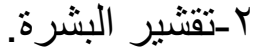

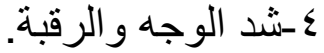 7-شفط الدهون (غير مـاه}

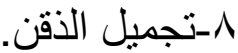

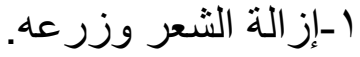
r-شد الجبين ورفع الحاجبين. 0-حقن الدهون (غير مـا سبقن).

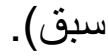
V-تجميل الأنف تصغيرًا أو تكبيرًا. 9-تجميل الثديين تكبيرًا أو تصغيرًا أو تصيرًا.

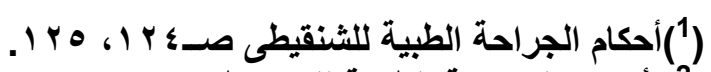

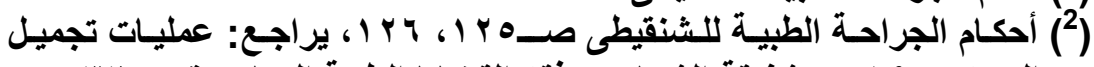

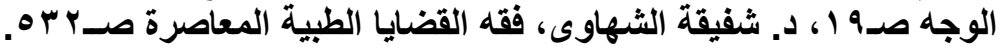

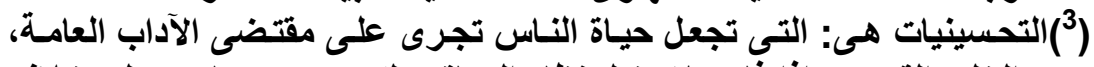

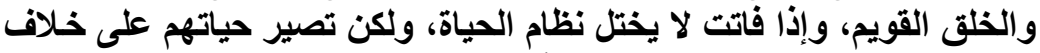

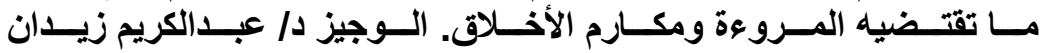

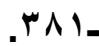

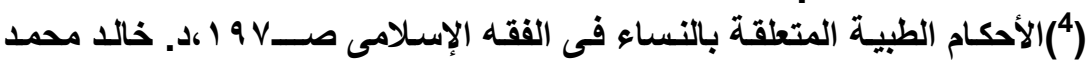
منصور،طام دار النفائس. 


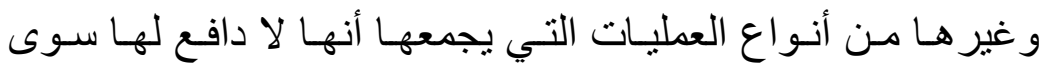
انز عاج المريض من مظهره ور غبته في إصـاحه إلى إلى مستوى مقبول

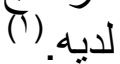

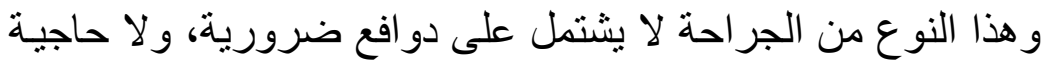

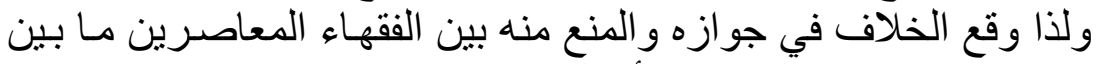

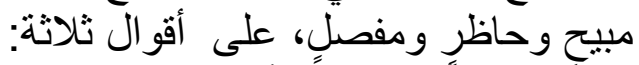

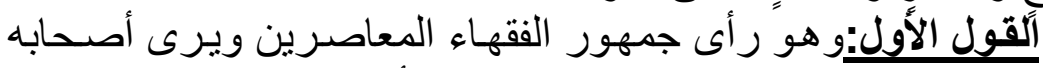

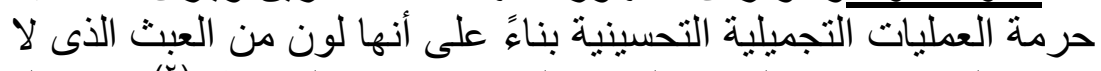

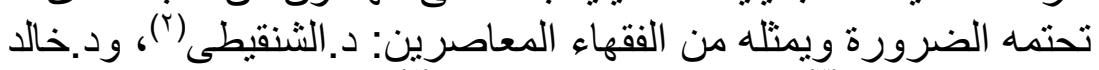

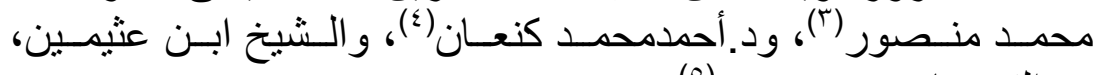

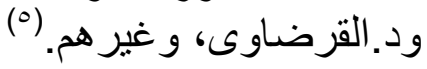

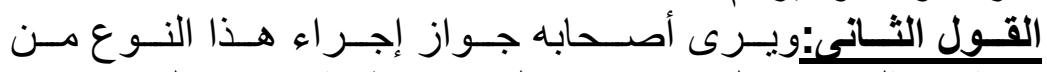

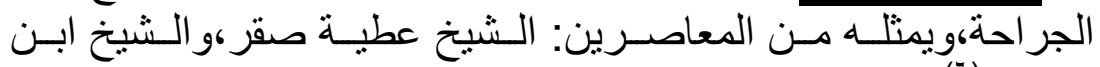

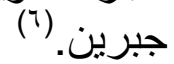
القول الثالث:ويرى أصحابه التفصيل بين كل حالة و أخرى، فيحكم

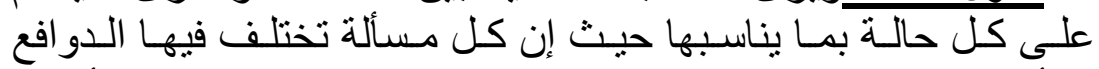

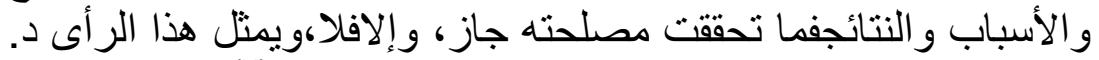

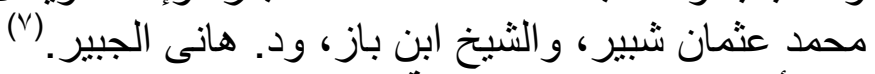
أدلة أصحاب القول الأول:

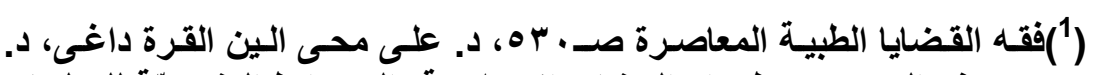

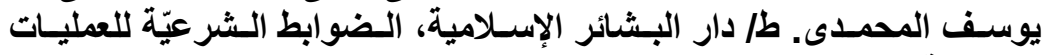

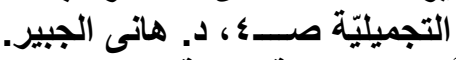

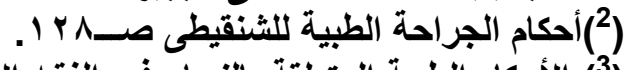

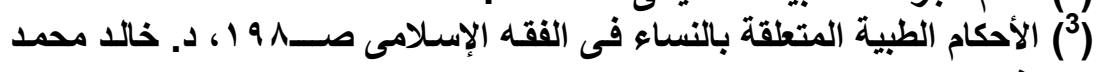

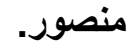

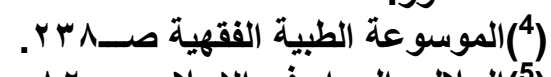

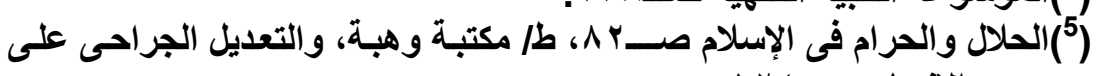

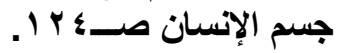

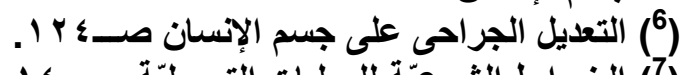

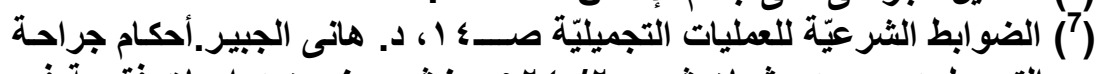

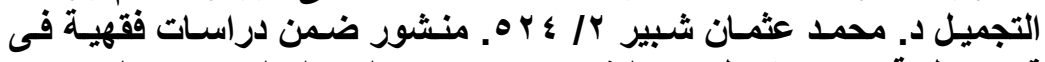

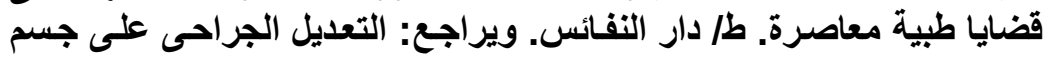

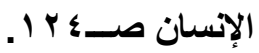


استدلو ا على ما ذهبو ا إليه بالكتاب، و السنة،و المعقول:

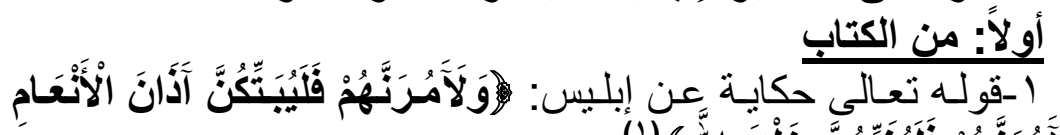

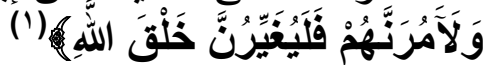

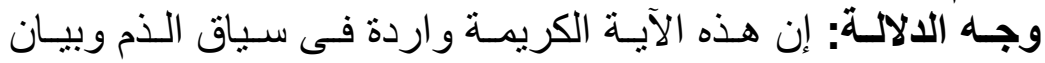

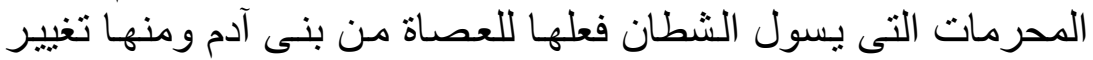

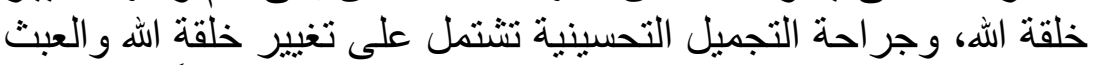

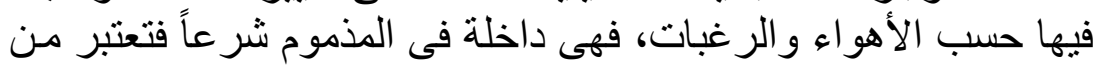
جنس المحرمات.

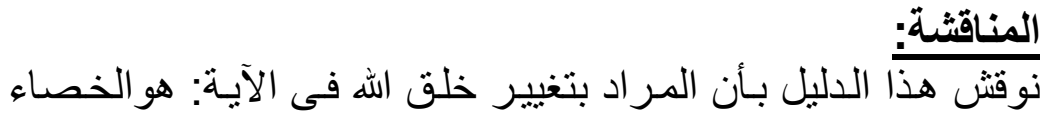

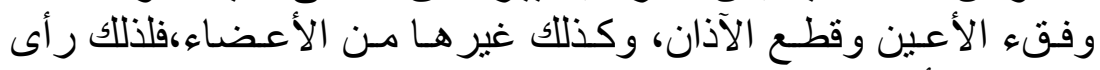

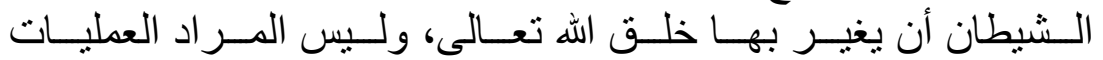

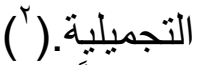

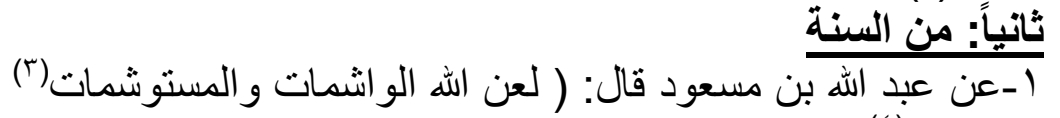

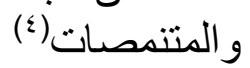

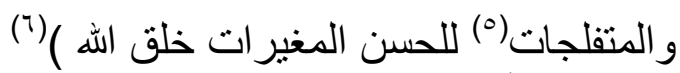

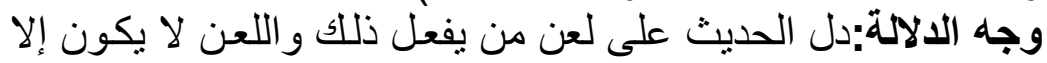

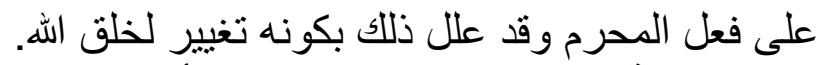

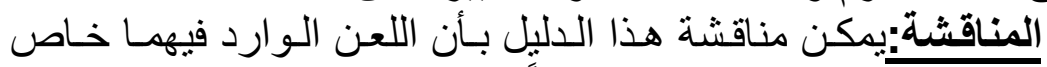
بالوشُ، و النمص، و الفلج ،وليس عاماً فى كل عملية تجميلية.

$$
\begin{aligned}
& \text { (1) (1) سورة النساء آية (1) ) ). }
\end{aligned}
$$

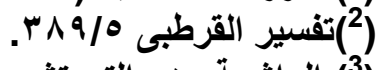

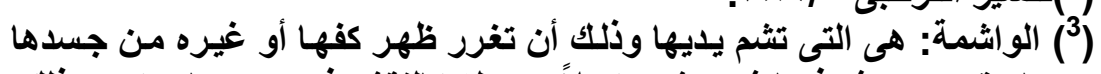

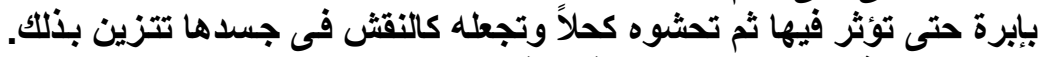

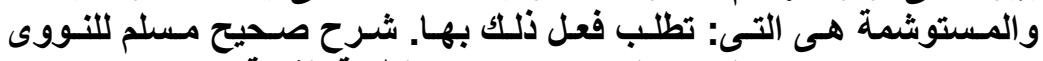

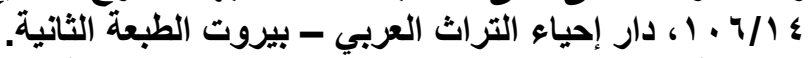

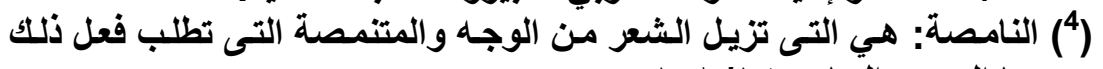

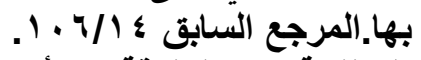

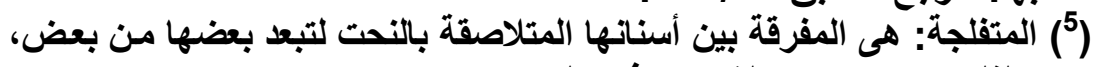

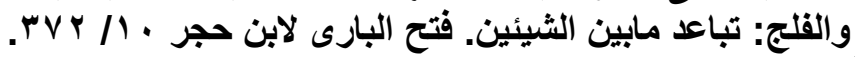

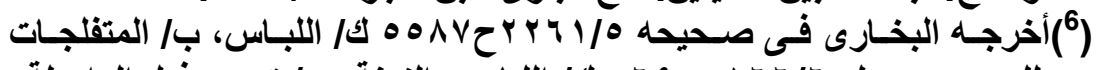
للحسن، ومسلم

$$
1 \wedge \varepsilon \text {. }
$$


ثالثاً: من المعقول

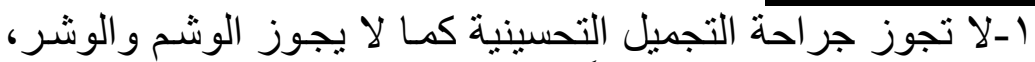

و النمص بجامع تغيير الخلقة طلباً للحسن و الجمال.

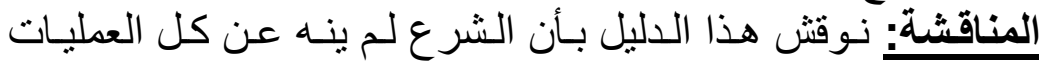

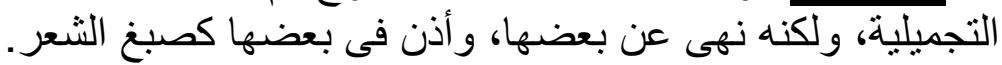

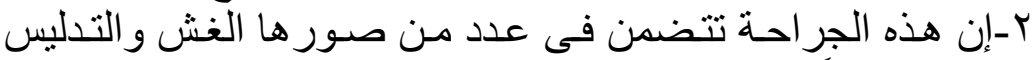

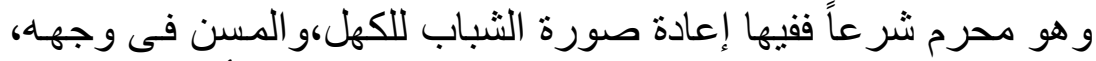

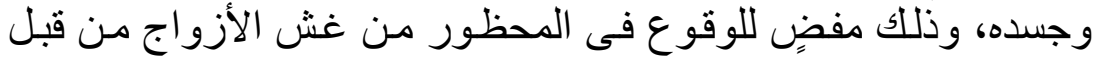

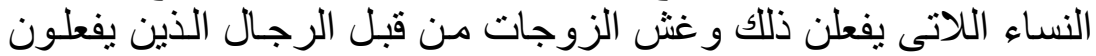

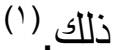

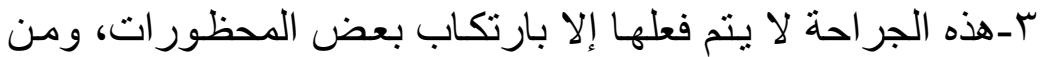

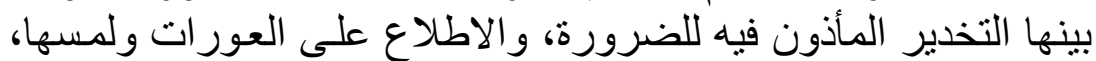

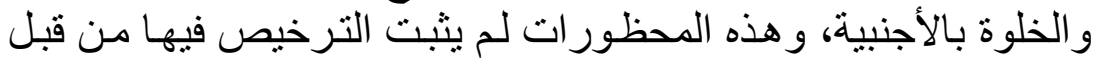

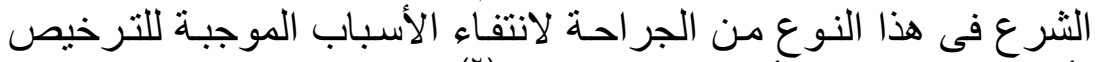

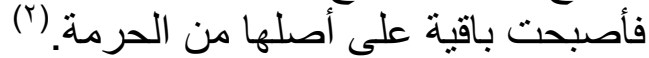

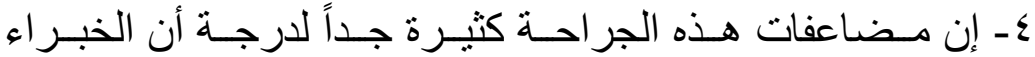
ينصحون بعدم إجر ائها وفى هذه الحالة يجب إمعان التهان التفكير قبل إجرائها

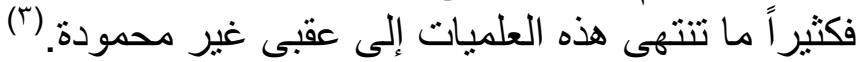

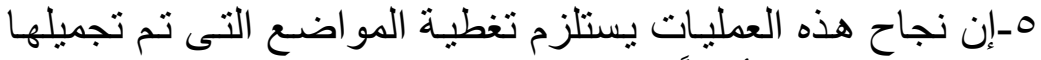

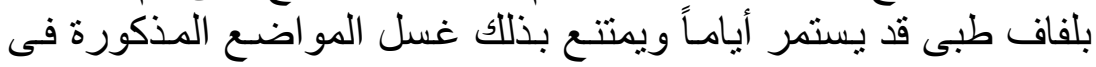
فريضة الوضوء و والغسل الواجب.

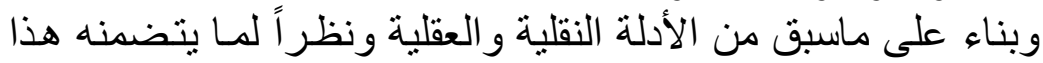

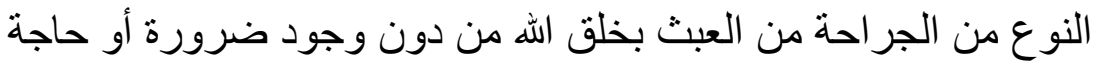

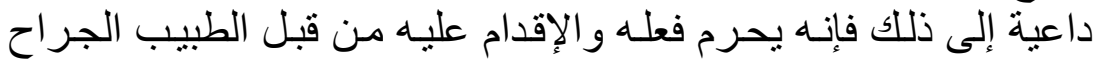

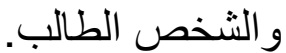
وتعتبر الدو افع التى يعتذر بفعلها من كون الثخص يتألم نفسياً بسبب

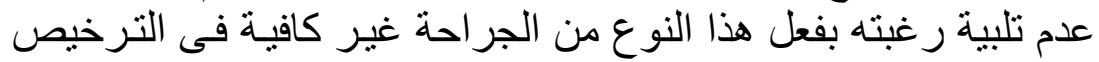
بفعله.

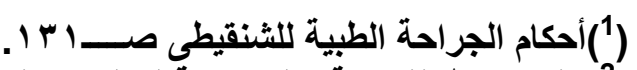

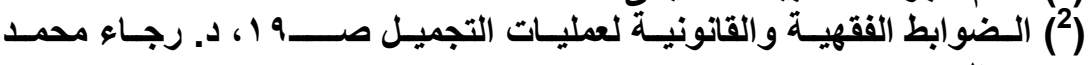
عبدالمعبود.

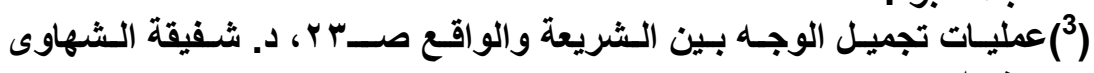

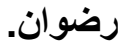


و علاج هذا النوع من الأوهام و الوساوس إنما هو بغرس الإيمان فى المى

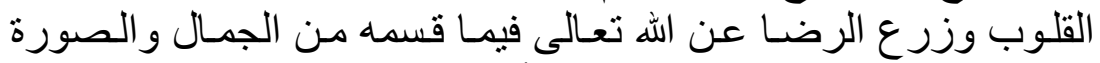
و المظاهر ليست هيى الوسيلة لبلوغ الأهداف و والغايات النبيلة و إنما يدرك

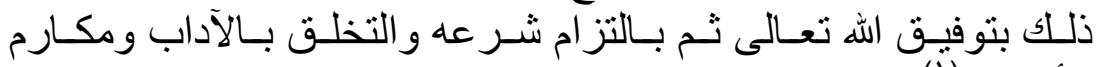

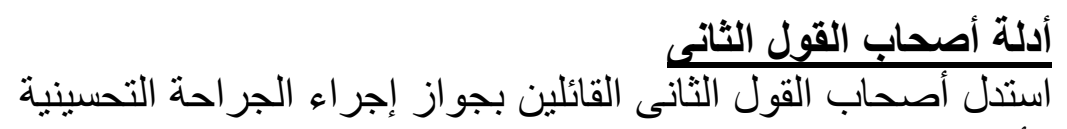

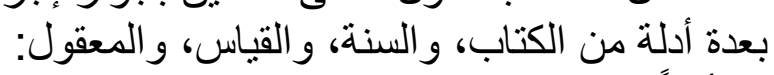

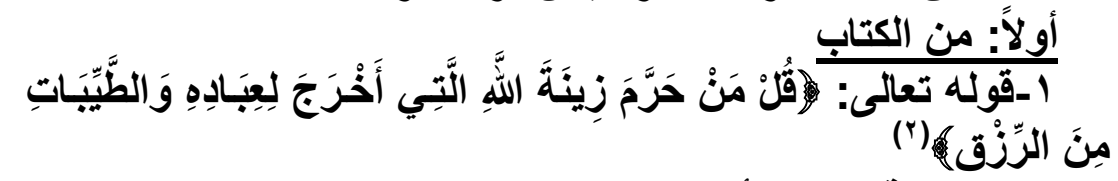
وجه الالالة: حيث تأتى عمليات التجميل فى سياق تحقيق الزينة التى التى

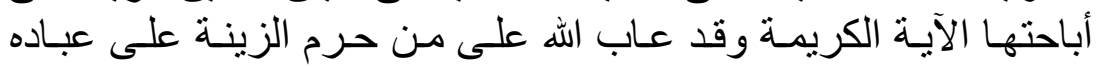

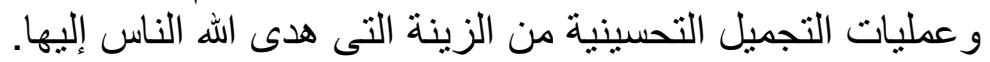

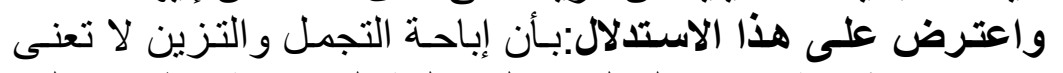
تعدى حدود الله فكثير من العمليات التجميلية التحسينية تنطوى على التى لتى مخالفات شر عية.

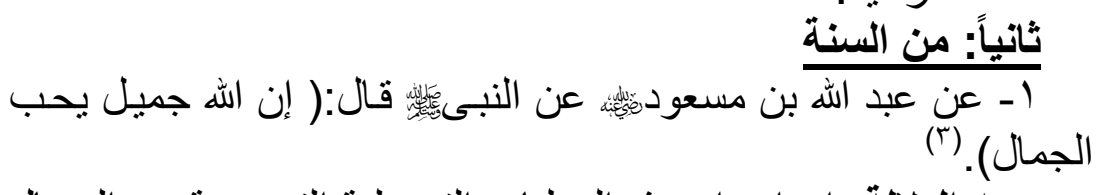
وجه الدلالة: إن إجراء هذه العمليات التجميلية التحسينية من الجمال

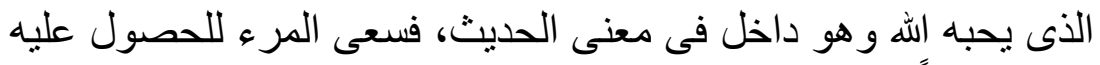

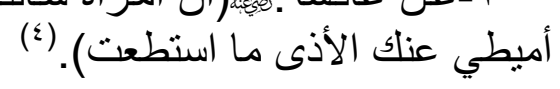

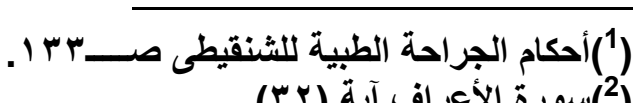

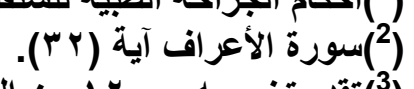

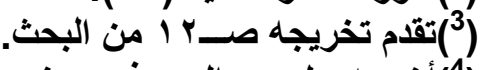

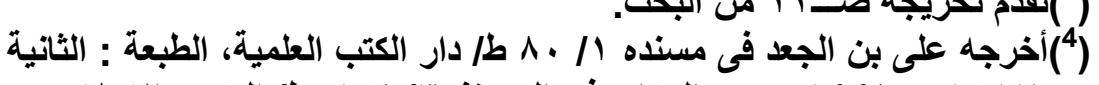

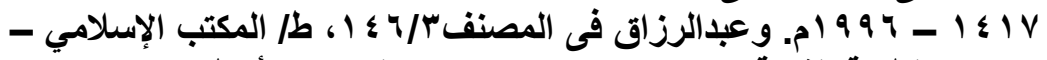

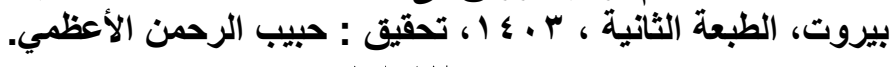
$1 \wedge \leqslant r$ 
وجه الدلالة: دل الحديث على جواز إزالة الأذى ما استطاع الإنسان

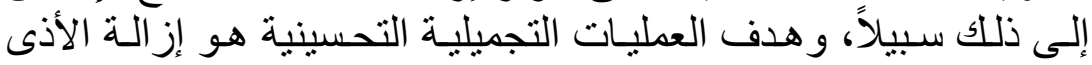

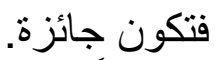

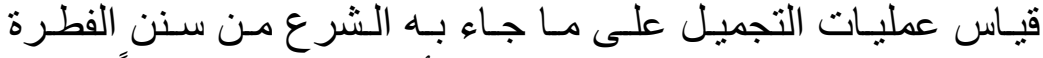

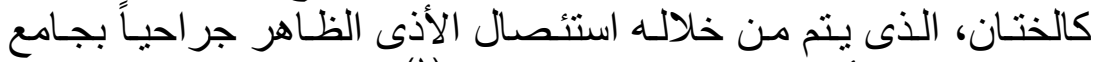

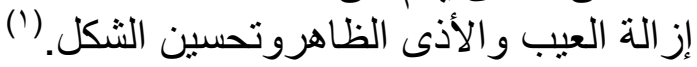

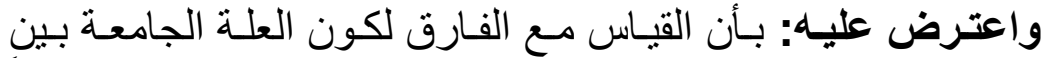

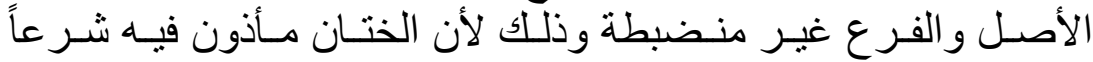

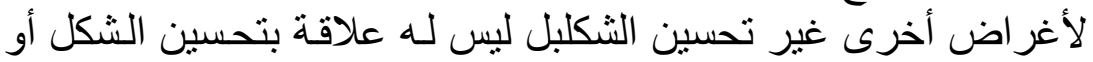

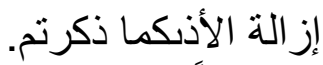
رابعاً: من المعقول

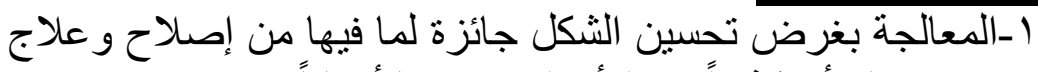
روحى، لاسيما وأن كثير اً من الأمر اض سبيها أحياناً نفسى الطي.

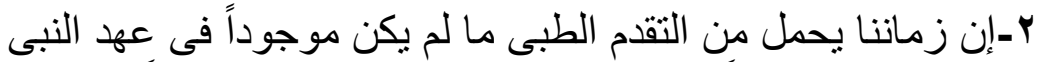

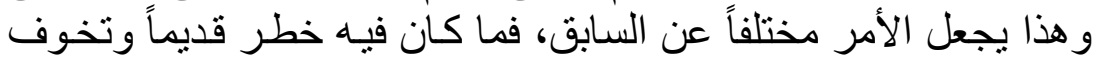

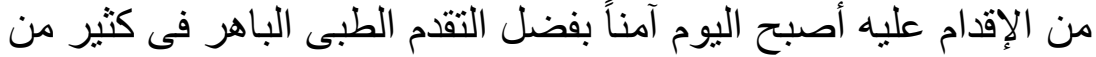

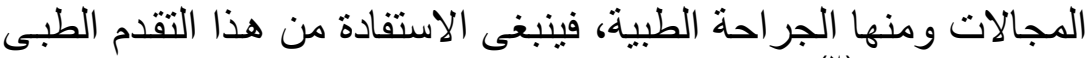

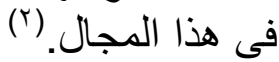

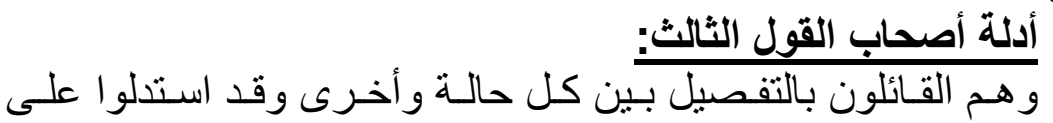

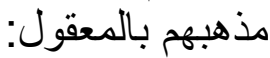

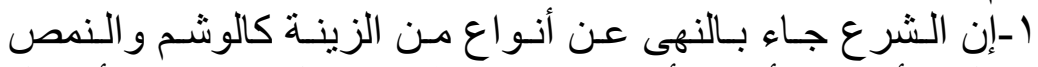

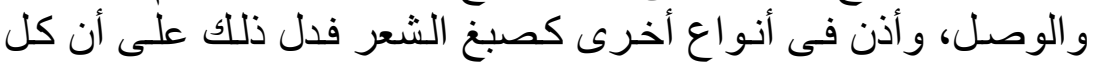

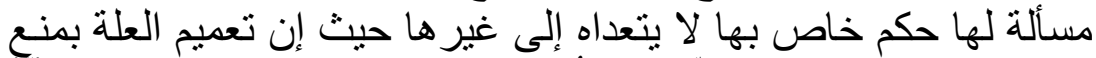

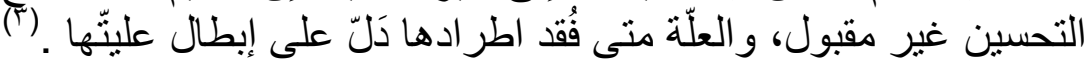

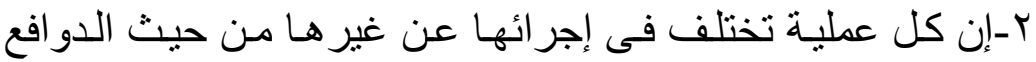

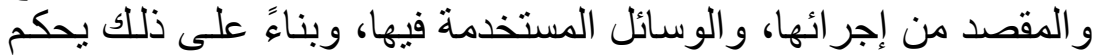

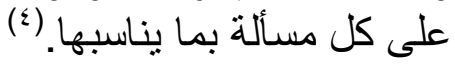

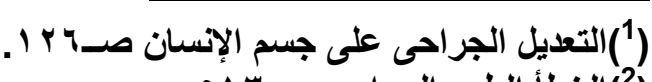

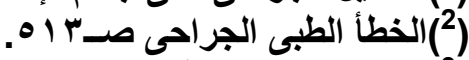

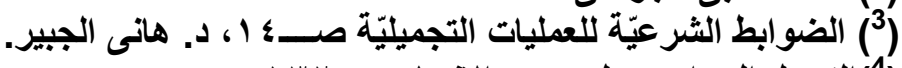

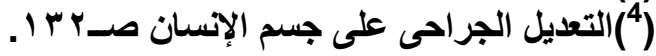
$1 \wedge \leqslant r$ 


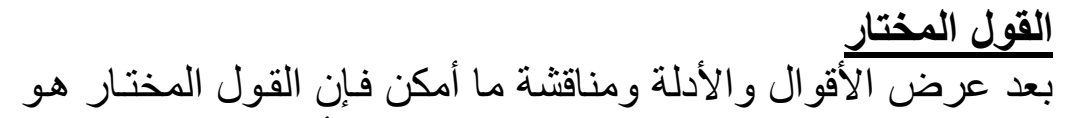

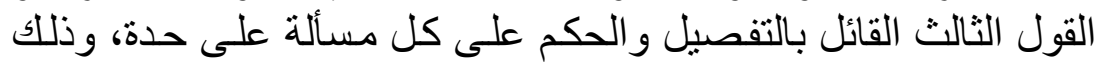

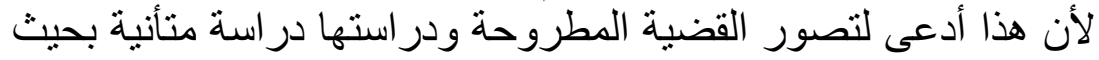

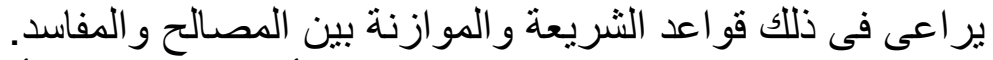

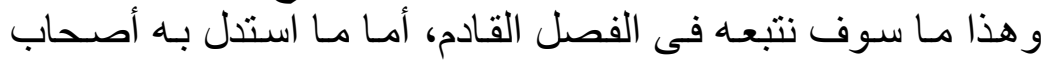

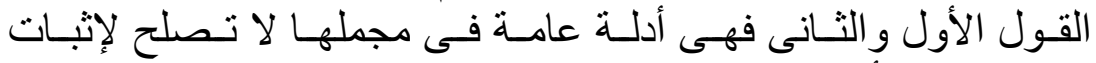

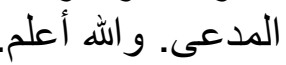

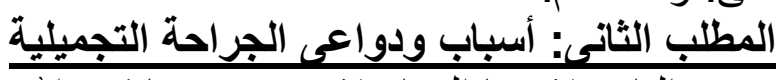

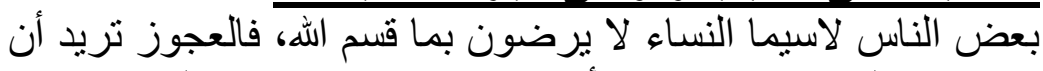

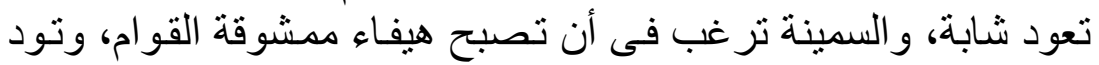

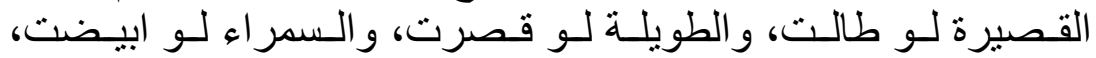

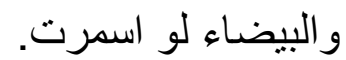

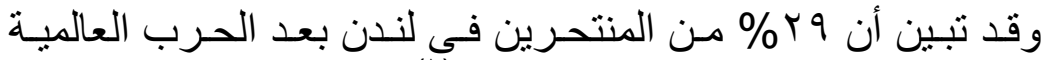

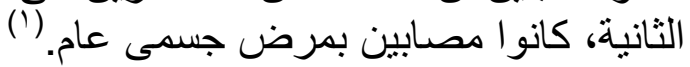

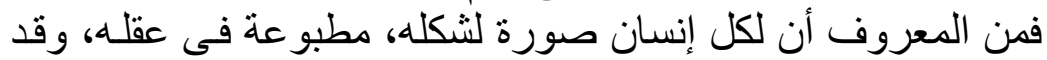

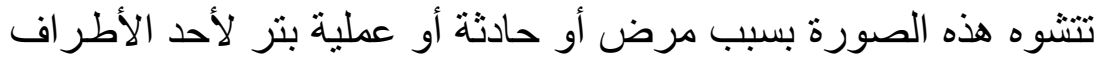

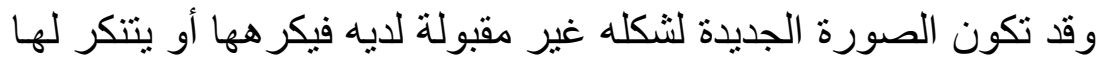

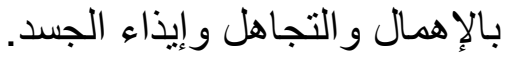
لذللك تعددت الدواعى و والأسباب التى تهؤدى إلى التى العمليات التجميليـة

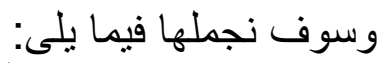

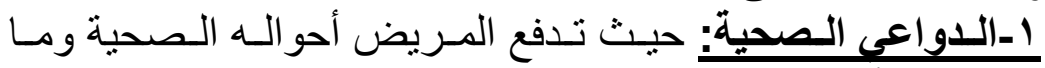

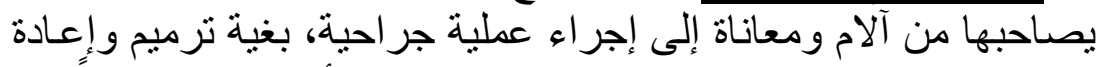

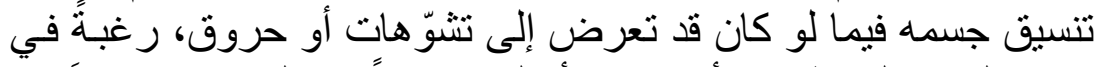

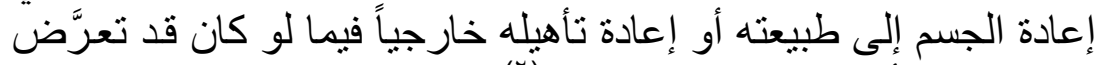

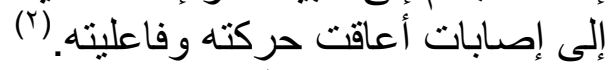

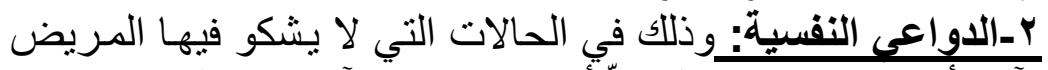

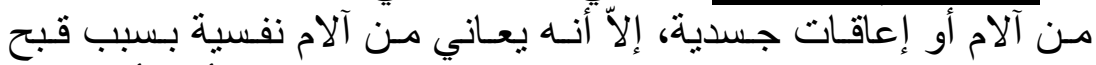

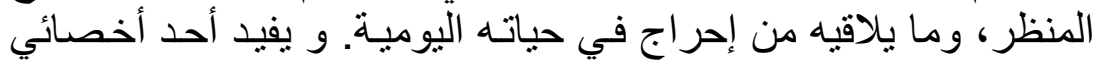

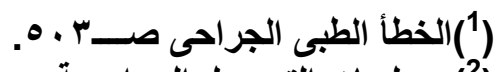

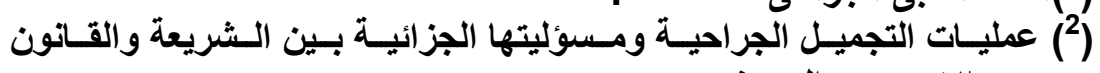
صـــ ؛ ، محمد الحسينى. 
الأمـر اض النفسية أنـه أُخضـع مجموعـة مـن المرضـى الذين حضروا

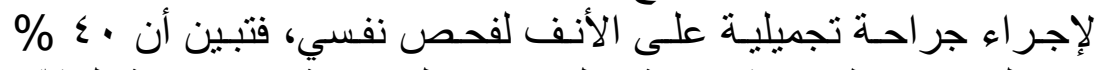

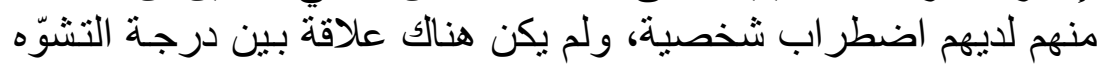
ومقدار هذا الاضطر اب النفسي.

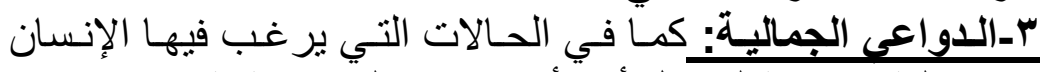

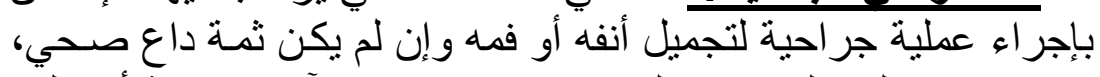

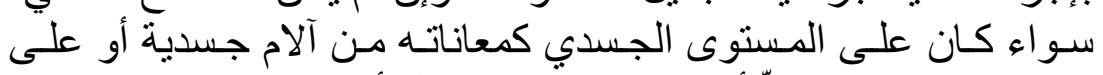

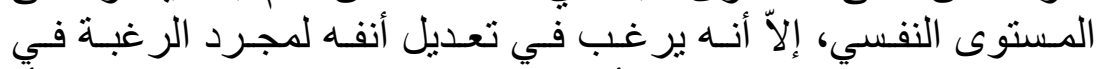

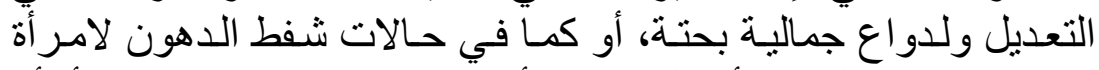

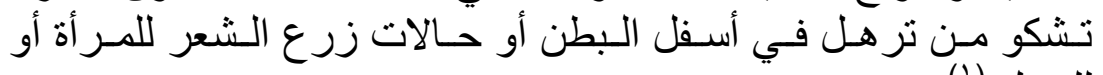

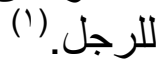

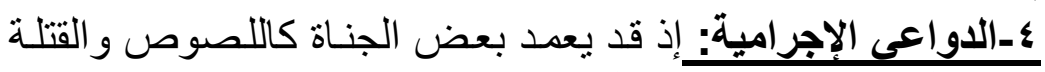

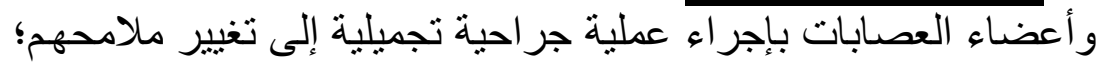

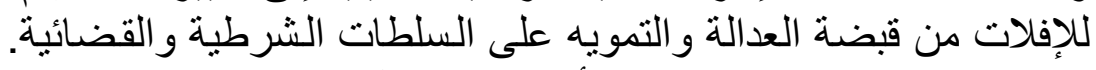

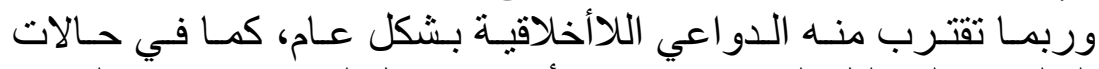

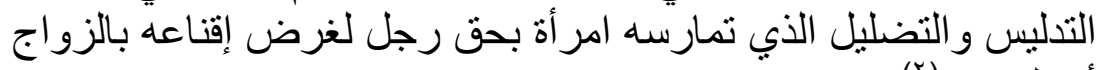

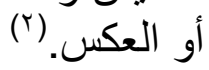

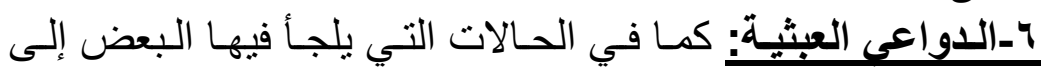

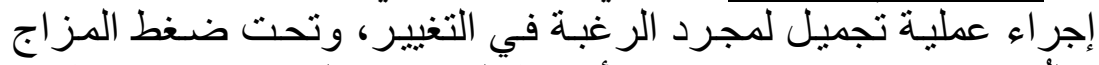

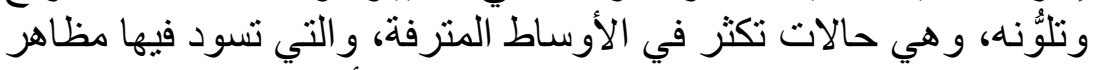

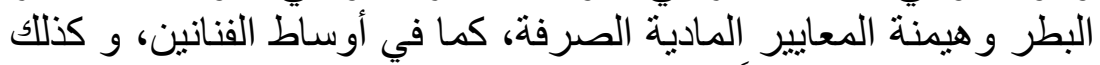
في بعض البلدان تحديداً.

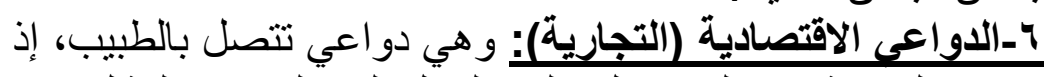

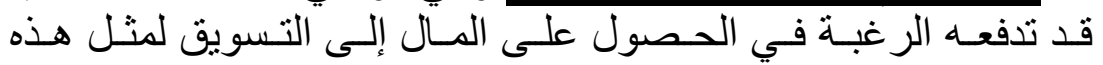

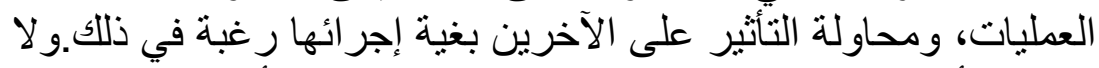
يخفى التأثير السلبي لثيوع مثنل هذه الدواعي على الإنى الأساسيات المهنية

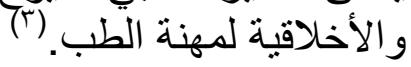

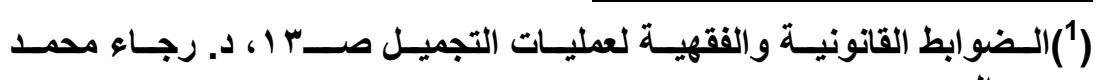
عبدالمعبود.

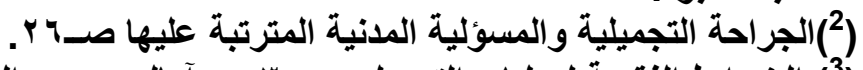

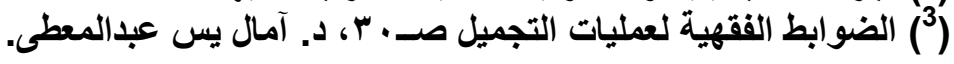




\section{المبحث الثالث \\ ضوابط إجراء الجراحة التجميلية}

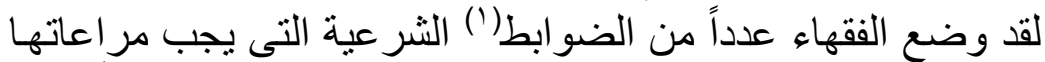

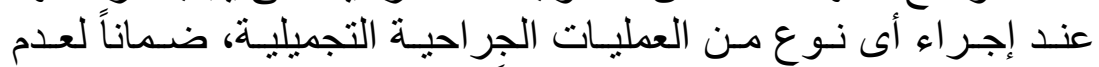

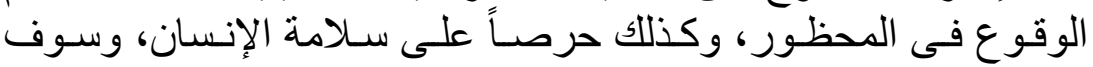

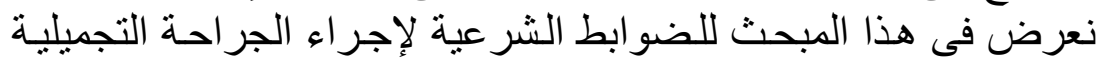

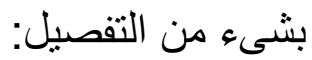

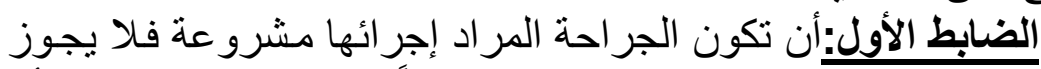

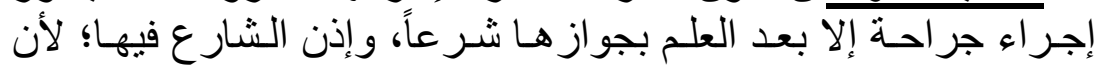

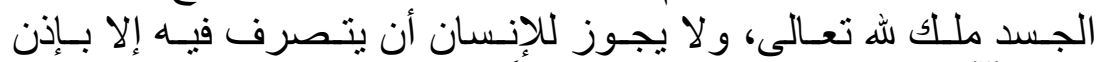

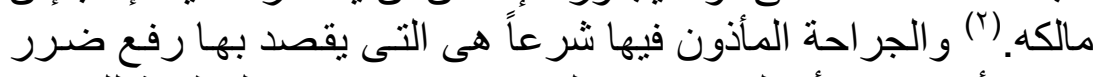

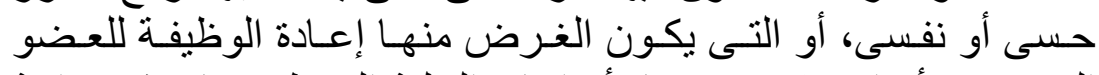

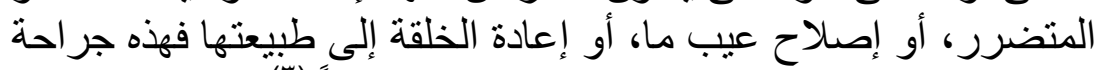

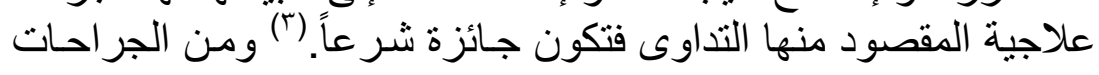

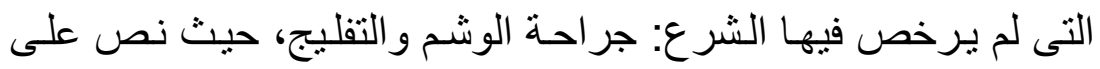
حرمتها.

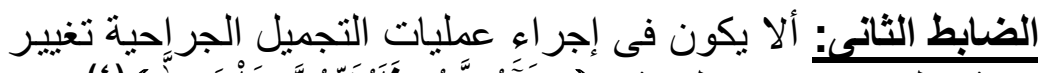

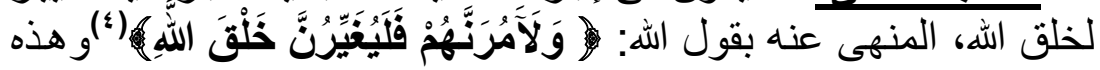
الاية قد اختلف المفسرون في المر اد منها على قولئن فئنين:

الأول: أن المراد بتغيير خلق الله فى الآية هو التغيير المعنوى، وذللك بتغيير ديـن الله وفطرتـه، ونسبة المخلوقات إلى غيلى غيره وكذللك تغييـر

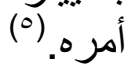

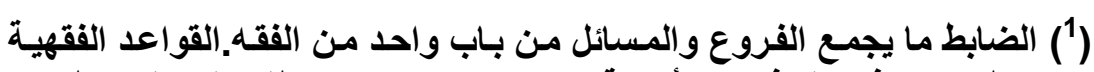

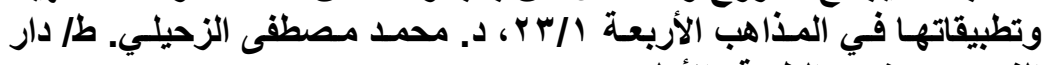
الفكر - دمشقي، الطبعة: الأولى.

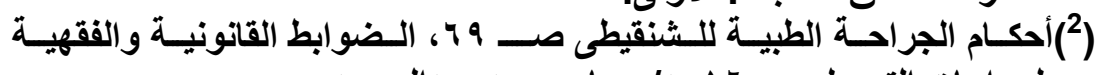

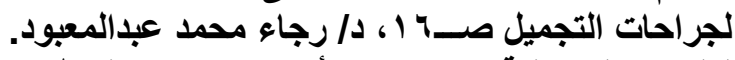

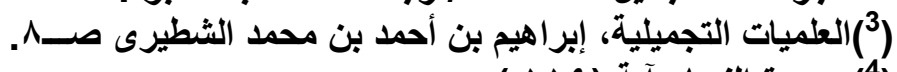

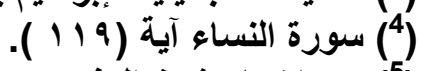

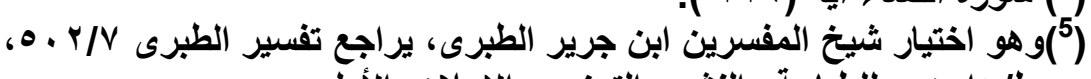

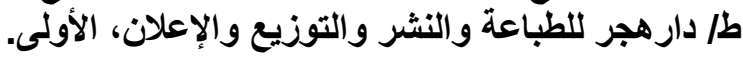
|人ะ7 


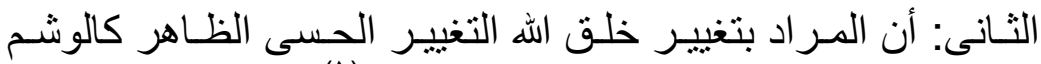

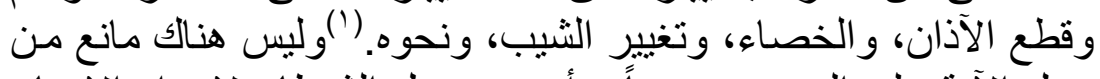

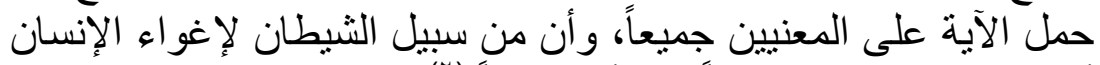

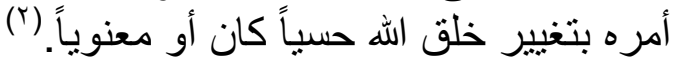

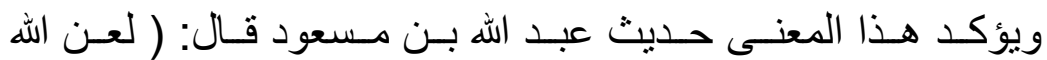

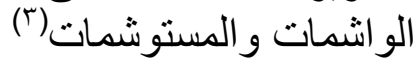

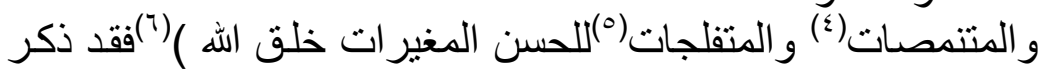

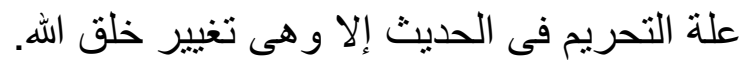

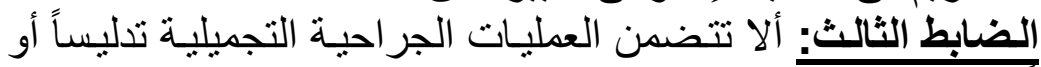

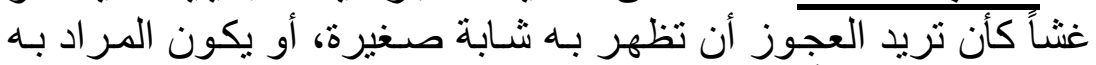

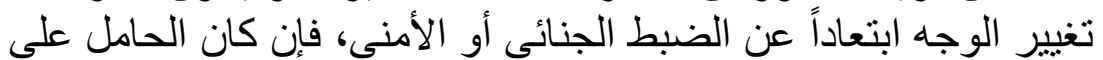

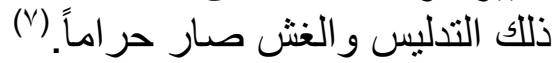

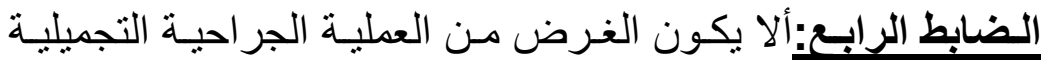

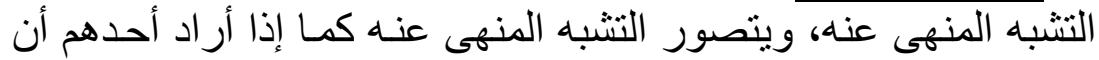

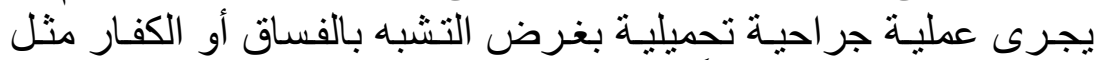

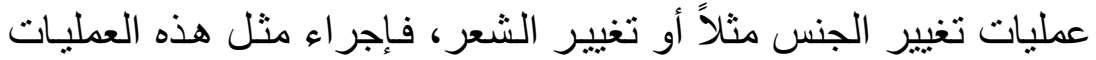

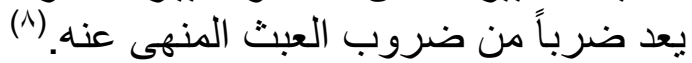

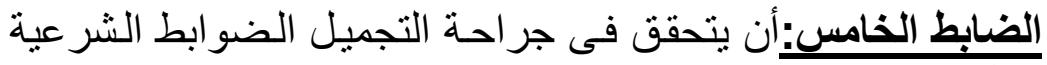
للأعمال الطبية و التى منها:

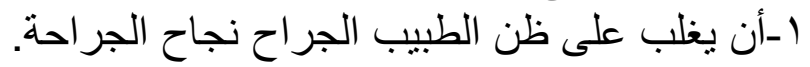

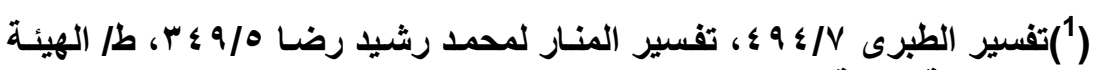
المصرية العامة للكتاب.

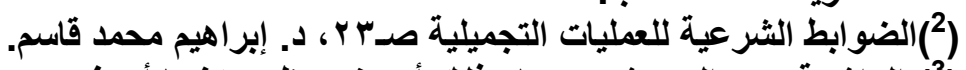

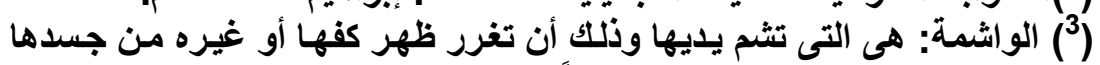

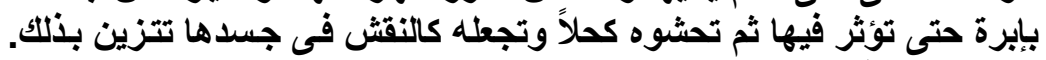

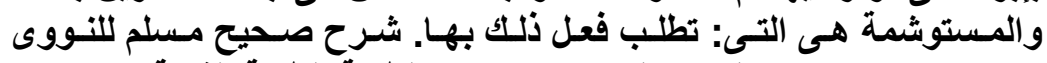

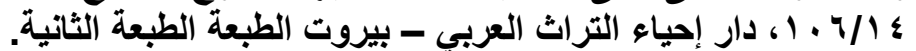

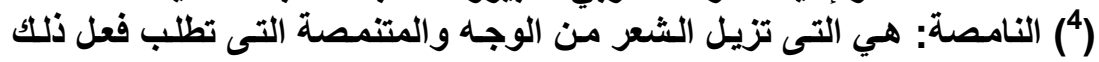

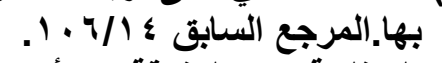

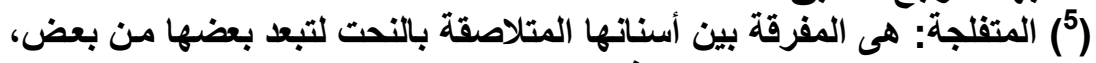

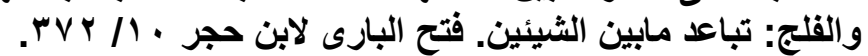

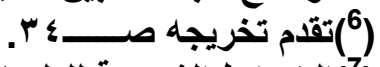
(7) (الضوابط الثرعية للعطميات التجميلية، د. مصلح بن عبدالحى النجار صــــ.

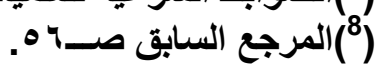




\section{r-مو افقة من سيجرى العملية أو وليه إن كان قاصر اً.}

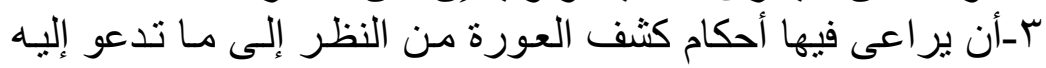

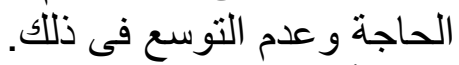

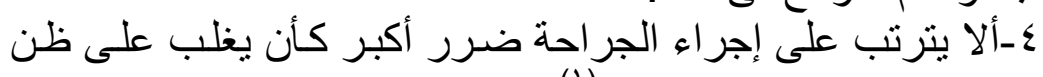

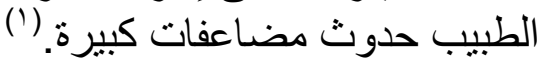

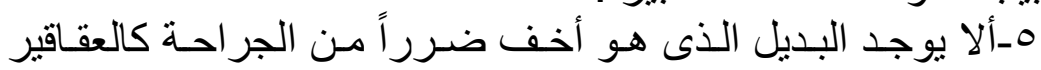

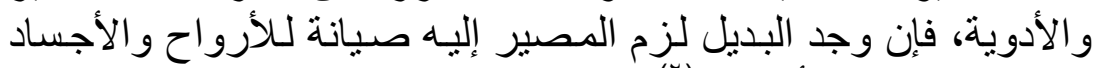

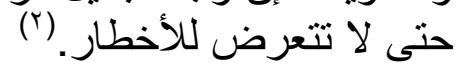

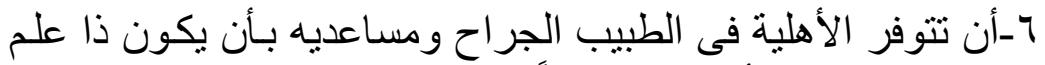

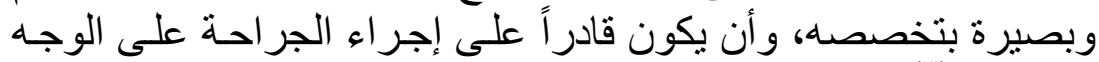

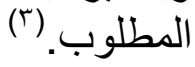
الضابط السادس:تجنب الإسـراف والتبذير فى الجر احة التجميليـة،

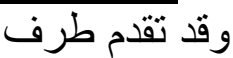
من هذافى مقدمة البحث فيها زيادة بيان حول نهى الإسلام عن الغلو في التجمل ونهيه عن كثير من الإرفاه، وحثنه على التقشف و عدم إهدار المـال

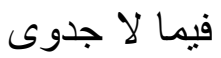
ور اءه، ولا مصلحة من تحصيله.

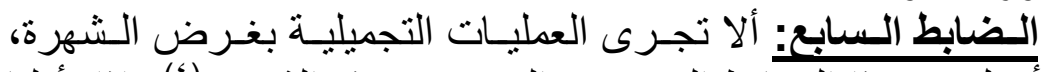

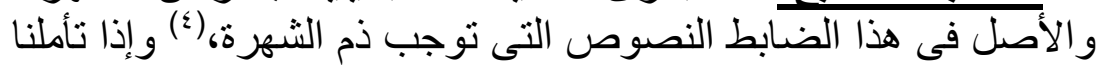

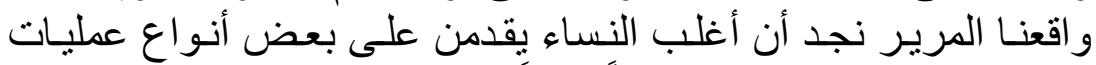

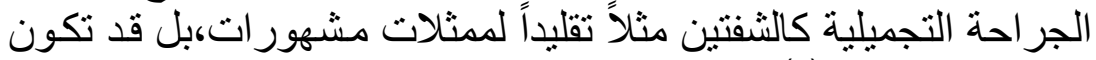

تلك الممثلة كافرة. (0)

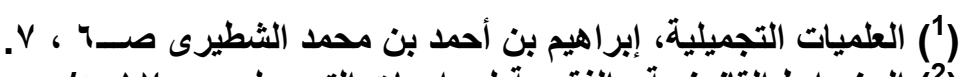

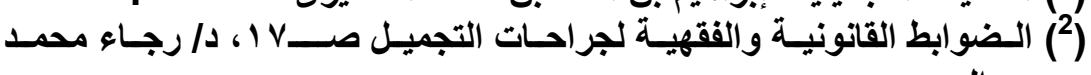

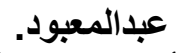

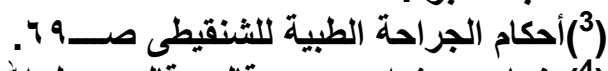

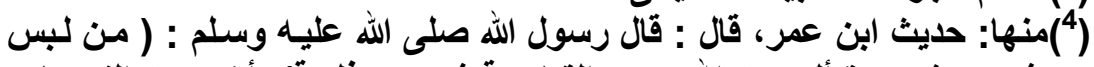

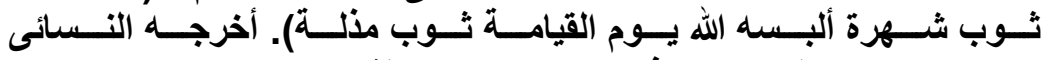
(

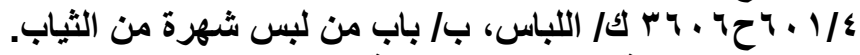

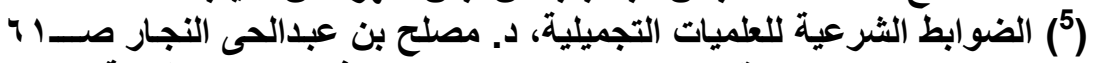

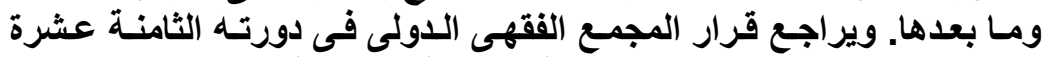

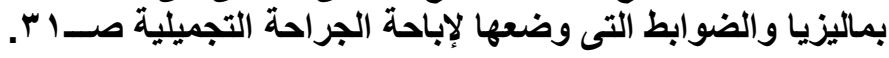
$1 \wedge \leqslant 1$ 


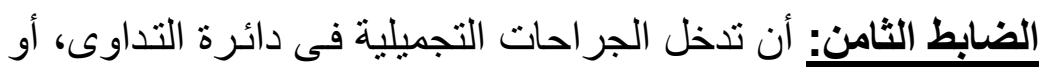

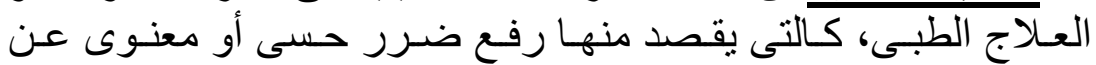

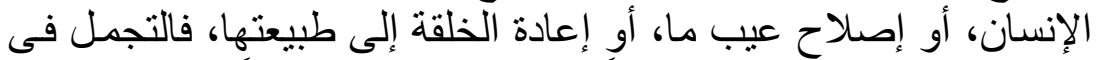

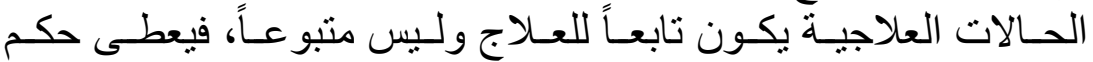

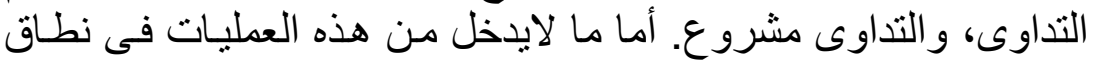

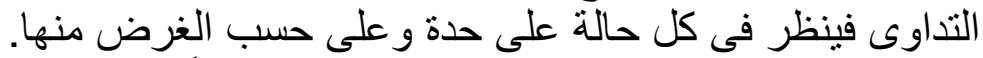

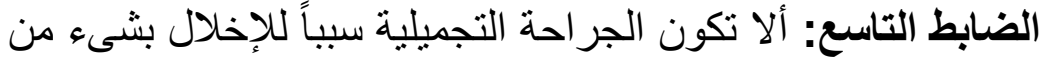

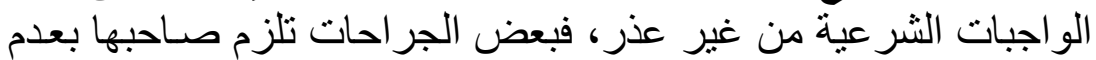

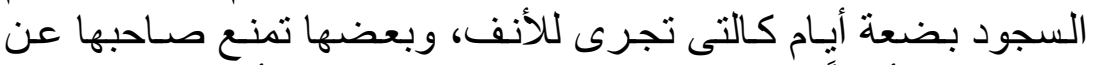

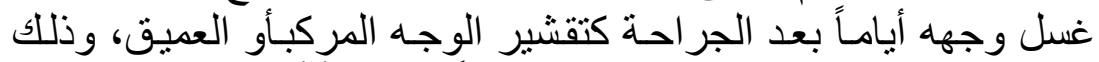

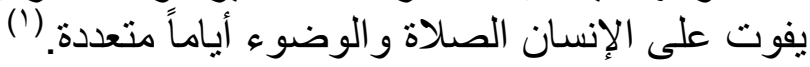

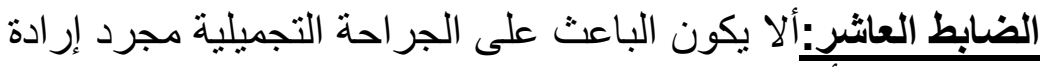

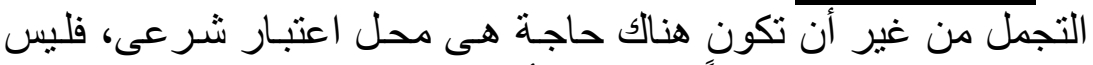

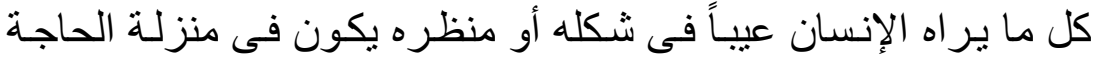

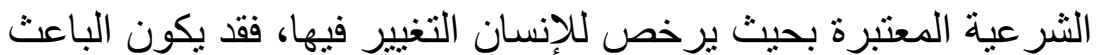

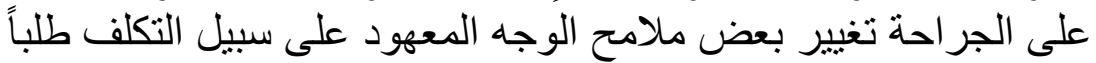

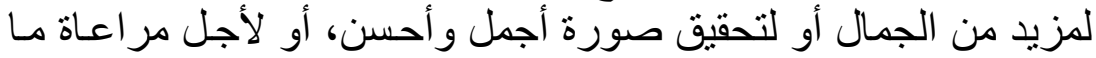
يعرف بالموضة كتصغير الثفاه أو تكبير ها. (r)

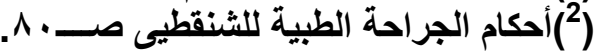




$$
\begin{aligned}
& \text { الفصل الثالث } \\
& \text { أحكام العمليات التجميلية الجراحية التية } \\
& \text { ويشتمل على مبحثين } \\
& \text { المبحث الأول: نماذج من العمليات الجراحية القيثين القديمة وأحكامها. } \\
& \text { المبحث الثانى: نماذج من العلميات الجراتية من الجملية الحديثة وأحكامها. }
\end{aligned}
$$




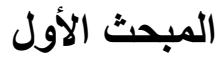

\section{نماذج من العمليات التجميلية الجراحية القديمة، وأحكامها}

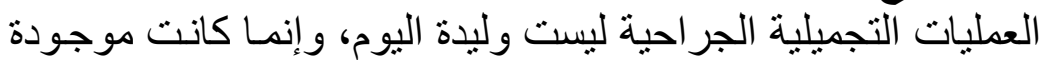

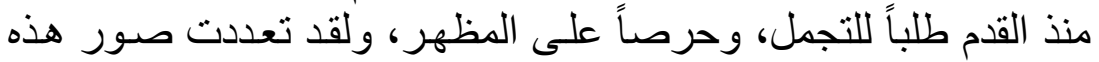

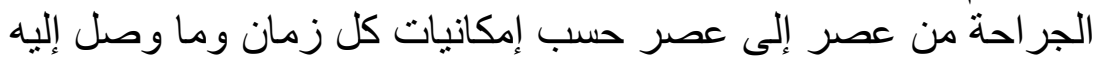

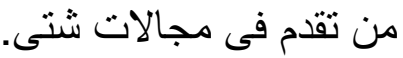

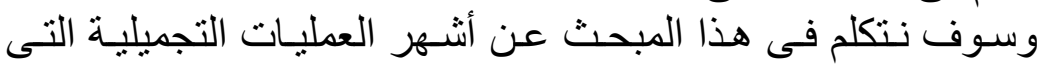
كانت معروفة منذ القدم وكان الناس يباثرونها ويحرصون النها عليها لاسيما

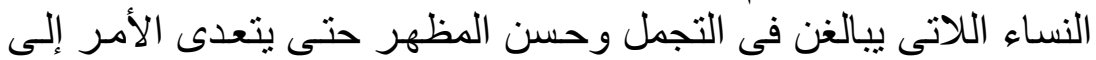
غير المشروع، وسيشتمل هذا المبحث على التى أربعة مطالب:

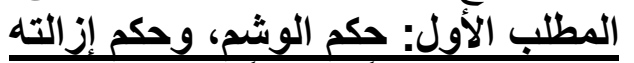

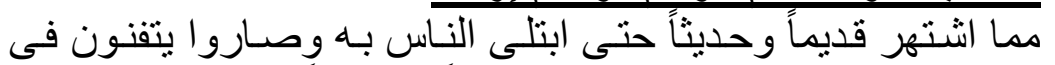

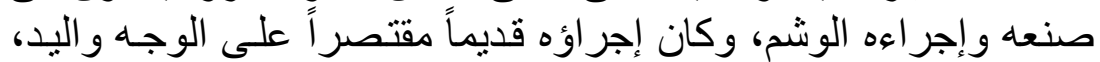

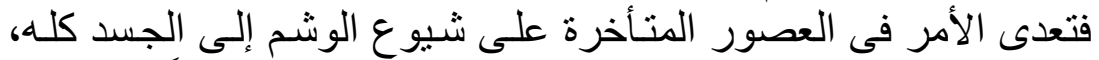

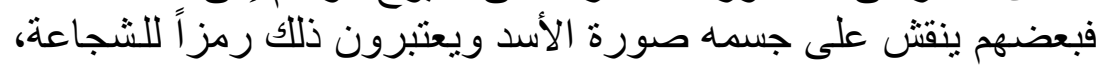

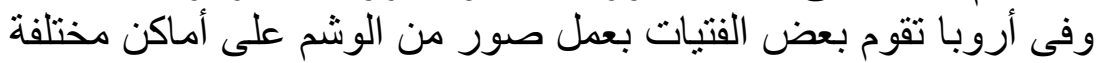

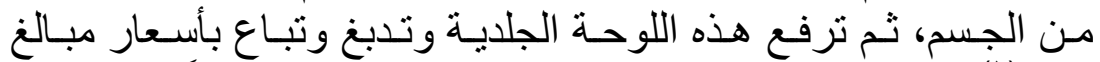

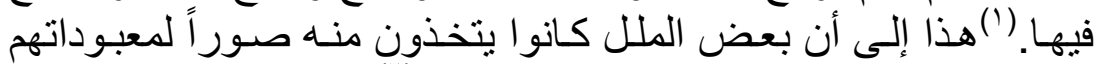

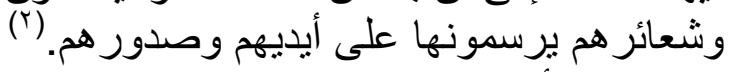
وسوف أتناول هذا المطلب فى فر عين: ولئن

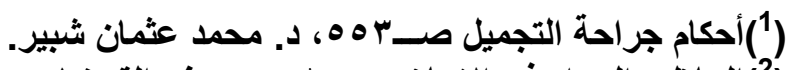

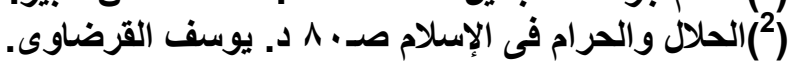
1101 


\section{القرع الأول}

\section{تعريف الوشم، وبيان حكمه الاول}

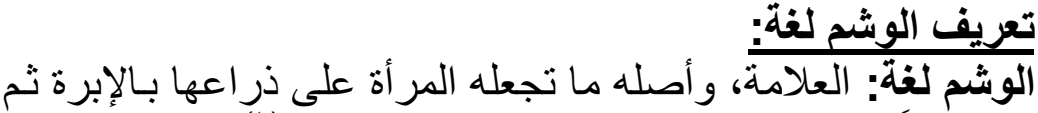

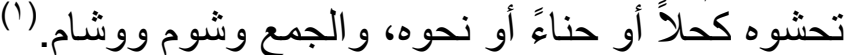

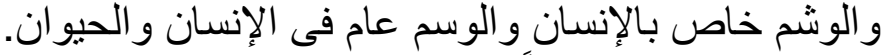

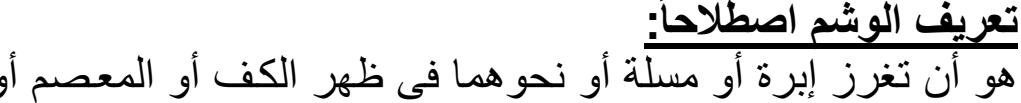

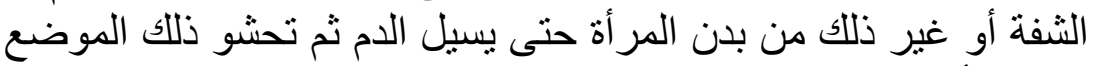

بالكحل أو النورة فيخضر وقد يفعل ذلك بدار ات ونقوش وقد تكثره وقد

تقلله. (؟)

وو اضح أنه ليس هناك فرق بين التعريف اللغوى و الاصطلاحى بـل

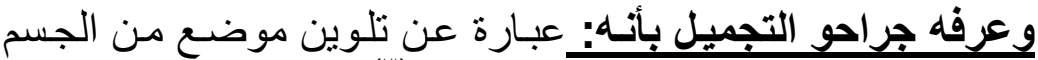

بلون معين عن طريق غرز الجمبل بائهة تحت الجلد.

أنواع الوشت:

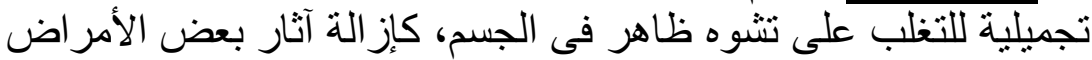
الجلدية، و التشوهات الخلقية.

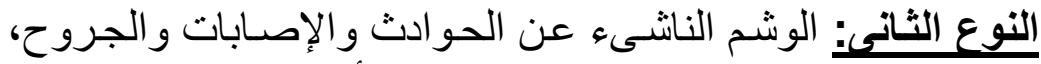

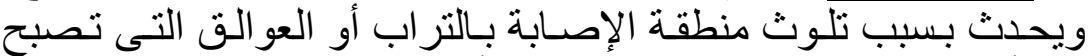

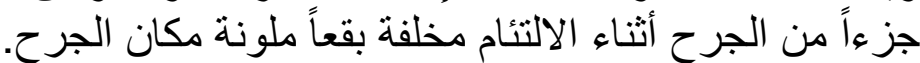

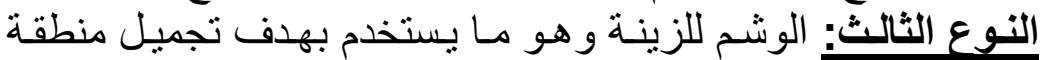

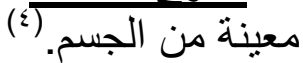

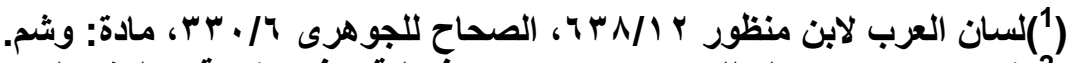

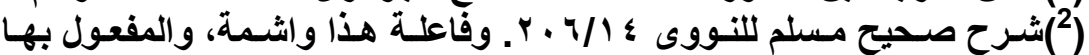

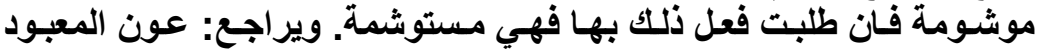
10.111 (3)(الجراحة التجميلية صالح الفوزان صـه 9 ؟، نقلاً عن أحكام زينة وجه المرأة 


\section{تحرير محل الوشي: النزاع:}

استثتى بعض الفقهاء من حرمة الوشم إذا تعين طريقاً للتداوى فإنهـ

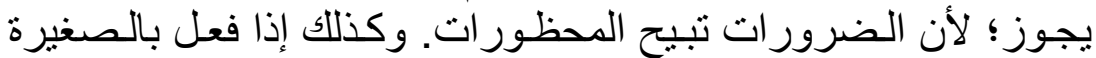

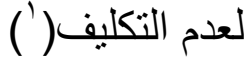

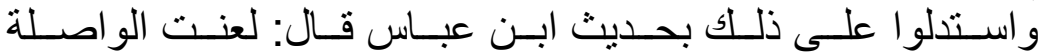

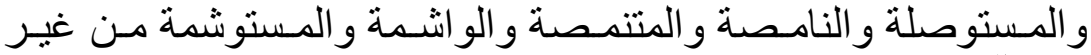

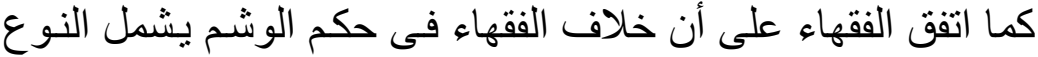

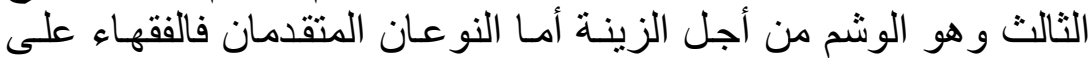

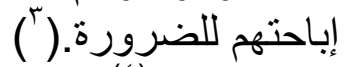
ثم اختلف( ) الفقهاء في حكم الوشم فيمـا عدا مـا تقدم وكان خلافهم

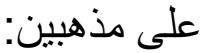

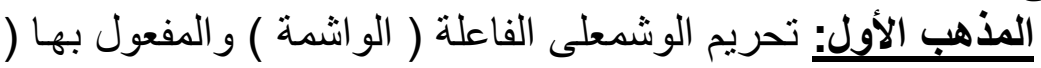

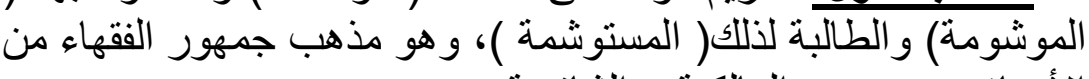

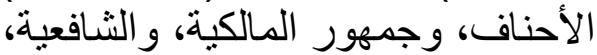
ورواية للحنابلة. (0) وعده بعض والفية المالكية و الشافعية من الكبائر يلعن فاعله. و الحكم بالتحريم عام: يشمل الرجل الرهل و المر أة على حد سواء.

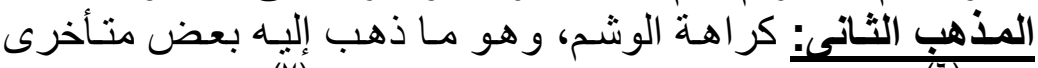

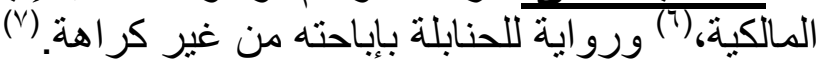

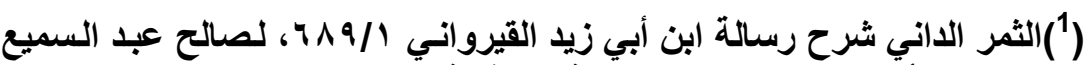

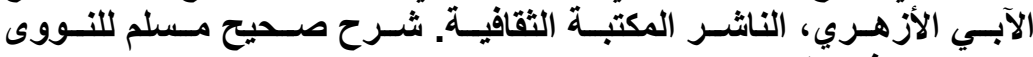

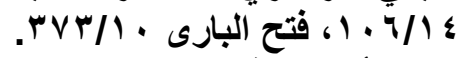

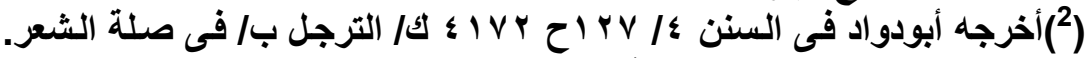

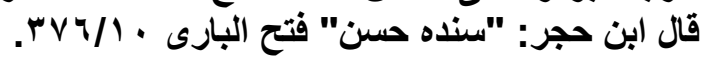

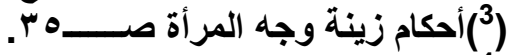

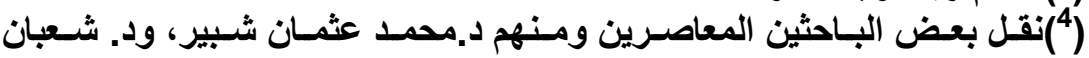

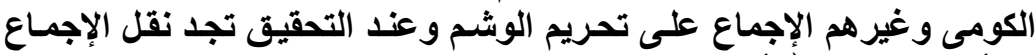

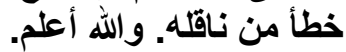

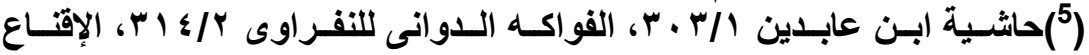

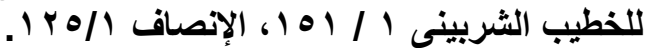

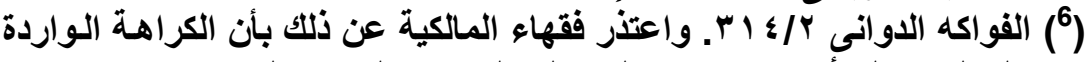

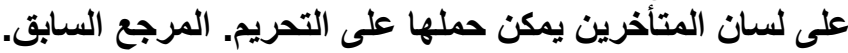

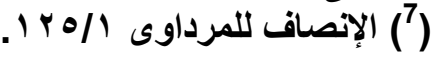




\section{أدلة أصحاب المذهبِ الأول:}

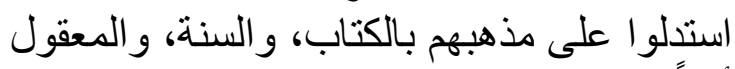

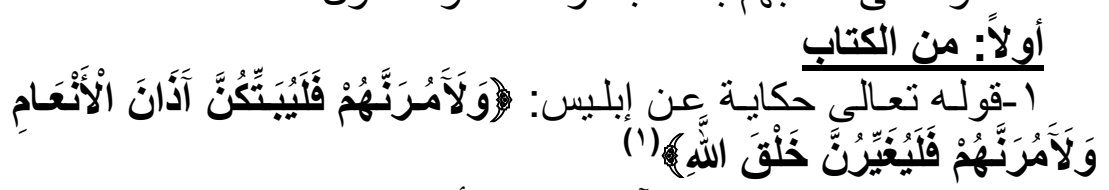

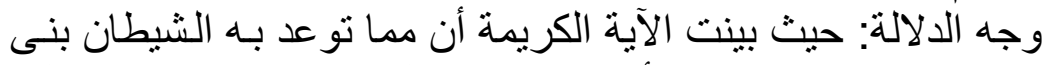

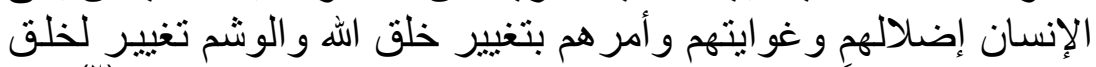

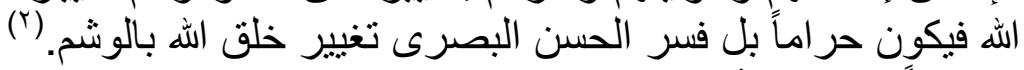

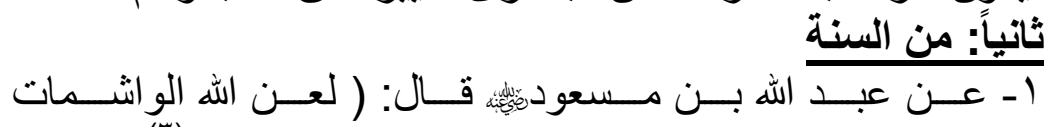

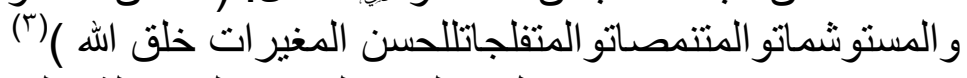

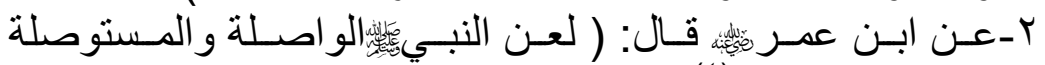

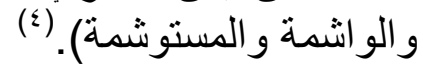

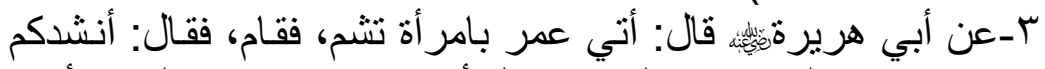

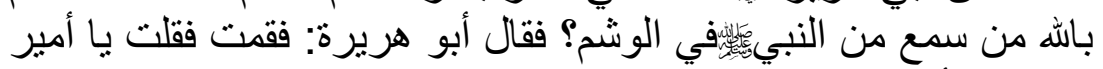

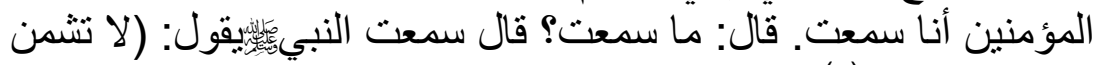

و لا تستوشنمن). (0)

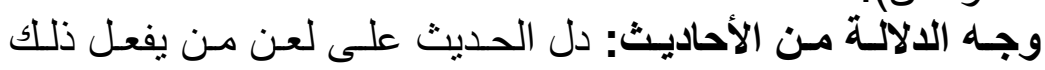

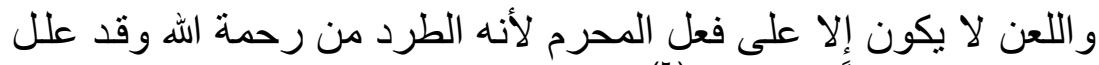

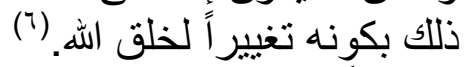
ثالثاً: المعقول نغيرل

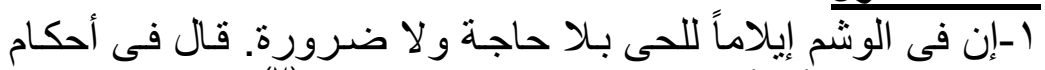

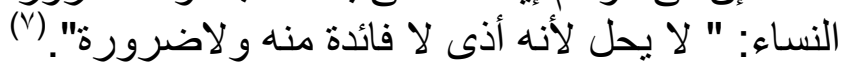

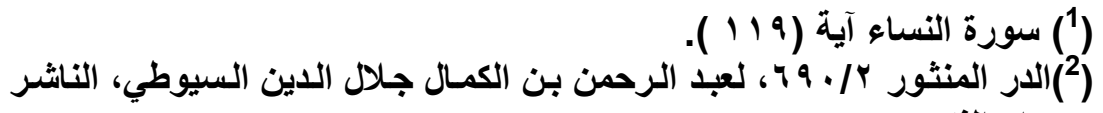
دار الفكر.

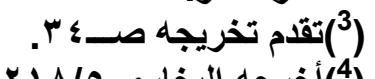

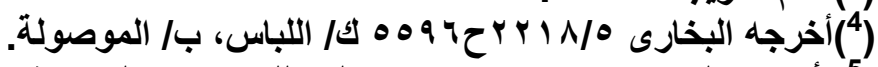

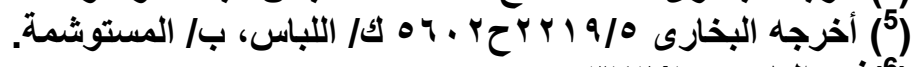

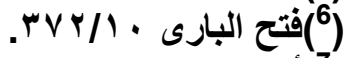

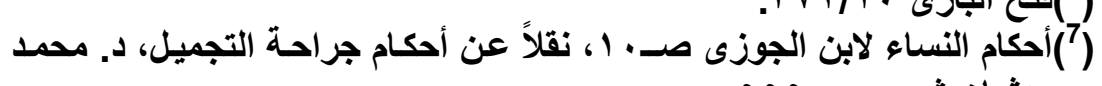
عثمان شبير صـــ00ه.

\section{$110 \leqslant$}


r-إن فيه تثويهاً للوجهـ و اليدين و البدن بهذا اللون الأزرق و النقش القبيح. (') (1) (1) أستدلة أصحاب المذهب الثاني:

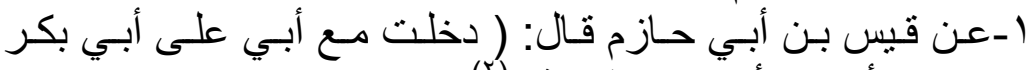

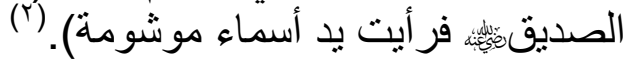

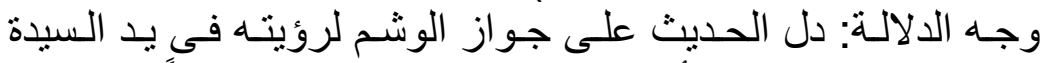

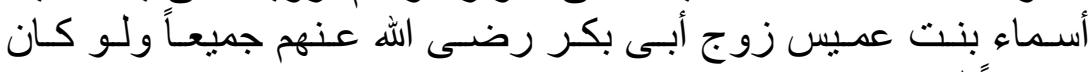
منو عاً لما صنعته.

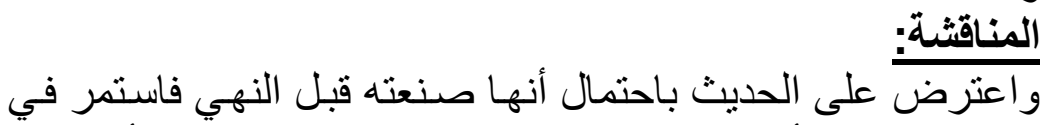

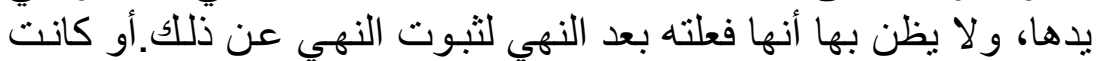

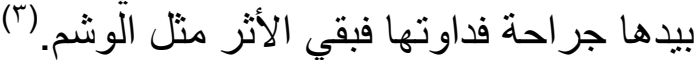

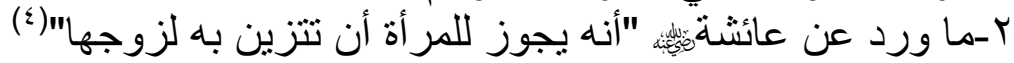
المناقثة: ويمكن مناقثنة هذا الحديث بعدة مناقثات:

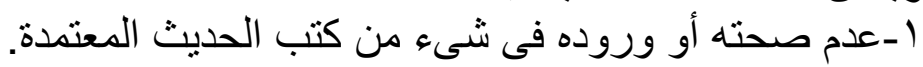

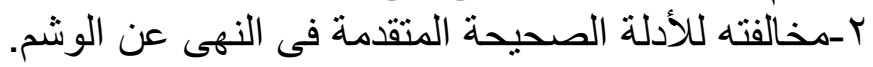

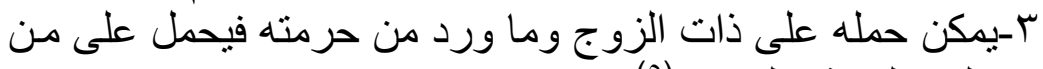

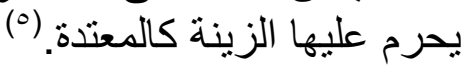

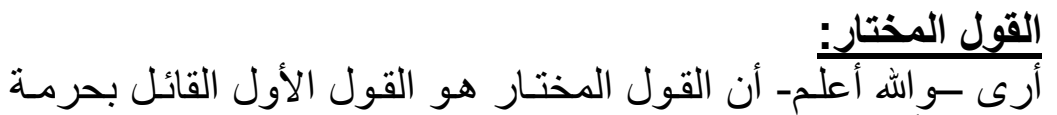

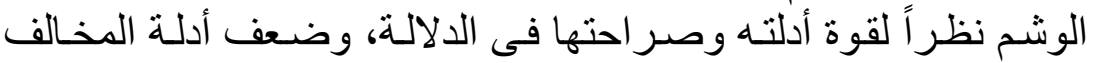

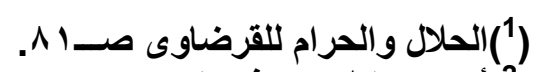

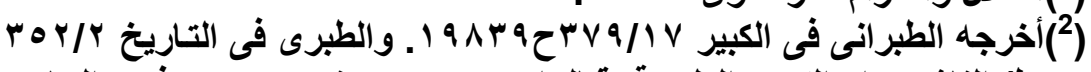

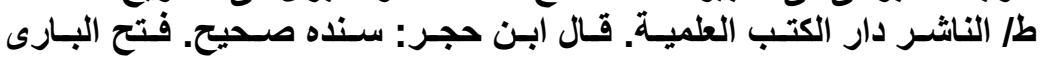
.rV4/l. (

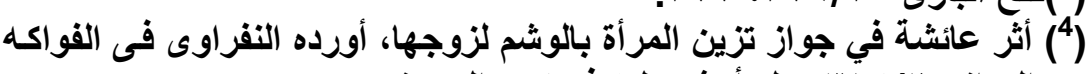

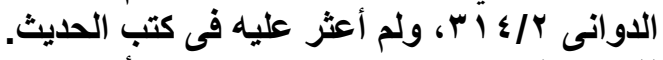

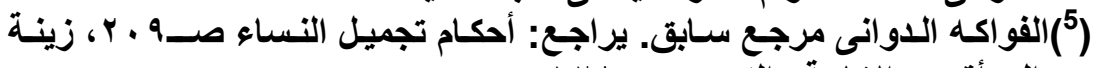

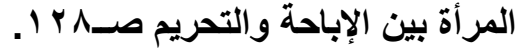
1100 
و عدم صحتها وصر احتها فى إثبات المدعى حيث أمكن الجواب عنها و الاعتذار لها.

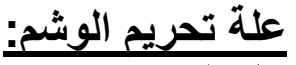
قال القرطبى رحمه الله: واختلف في الهي المعنى الذي نهي لأجلها؛ فقيل:

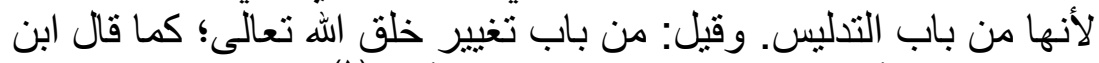

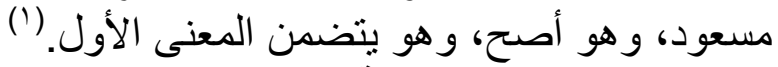

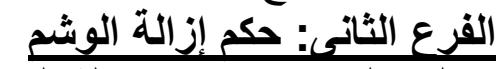
اختلف الفقهاء فى حكم إز الة الة الوشم الوشم على مذهبين:

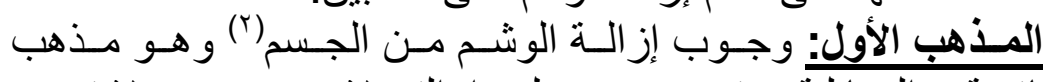

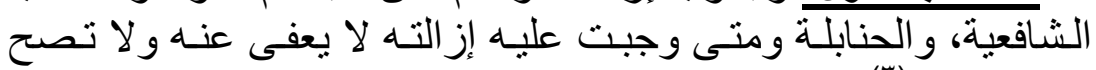

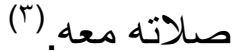
و استدلو ا على مذهبهم بنجاسة الموضع الموشوم ومن ثم تجب إز الته لعدم صحة الصلاة من حامل للنجاسة. المذهب الثانى: عدو وجوب هاب إز الة الوشم من الجنة الجسم ولو كان للزينة

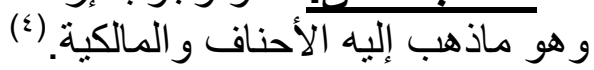

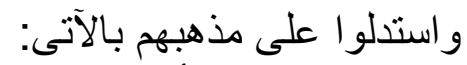

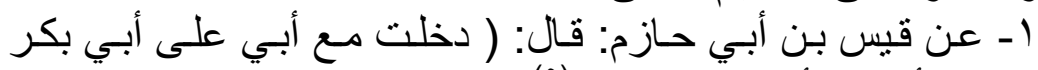

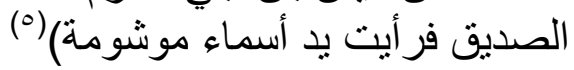

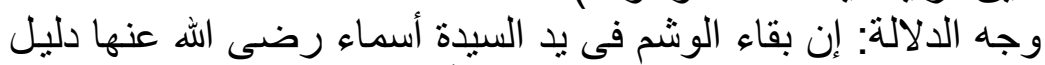

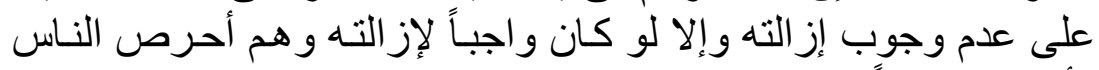
و أكثر هم اتباعاً.

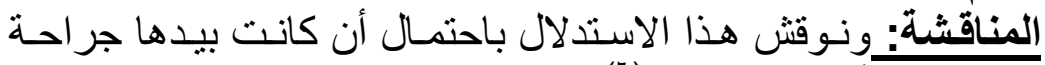

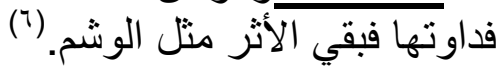

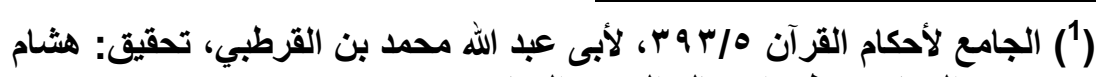

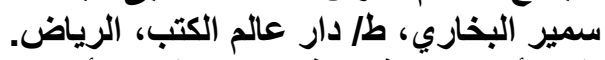

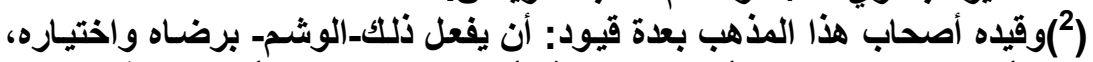

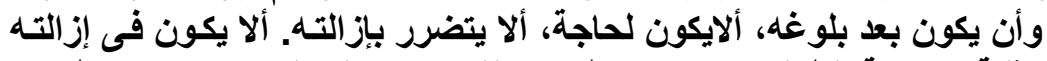

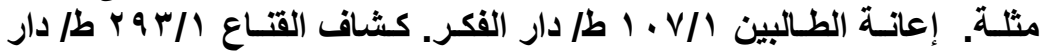
الفكر.

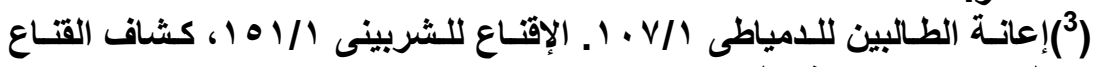

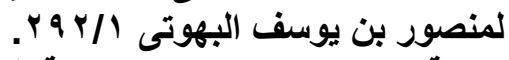

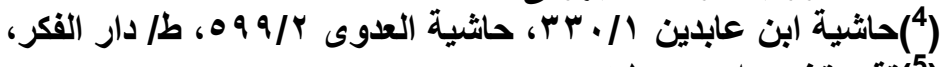

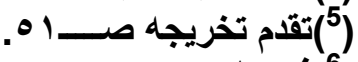




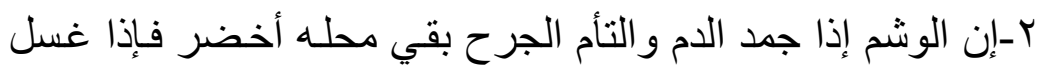

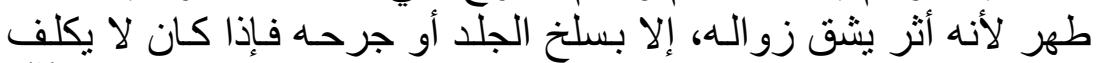

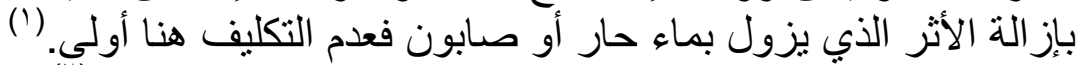

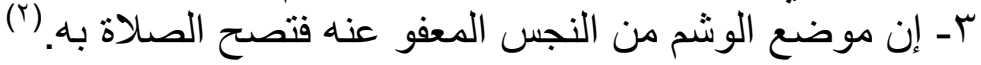

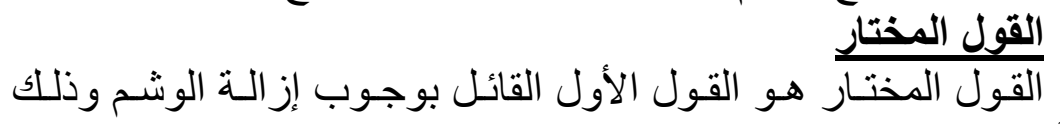

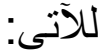
ا-ـإمكان إز الة الوشم من الجسد فى العصر الحديث بيسر وسهولة

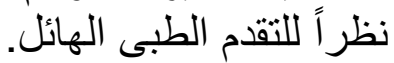

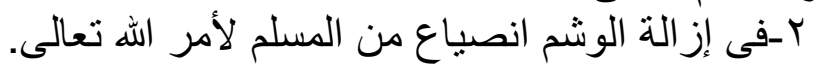

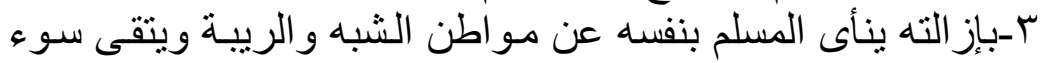

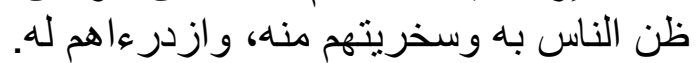

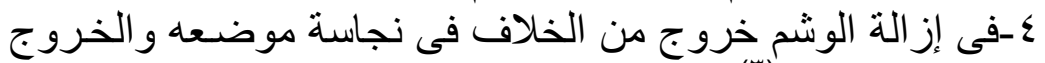

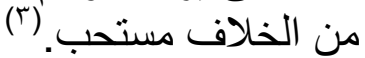

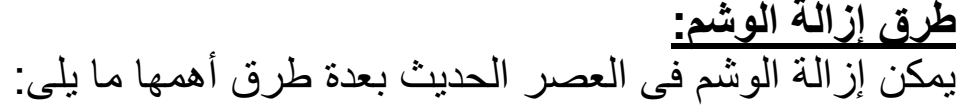

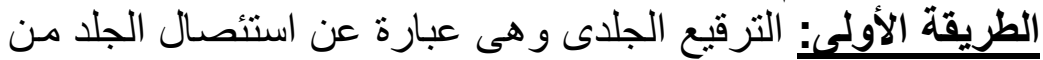

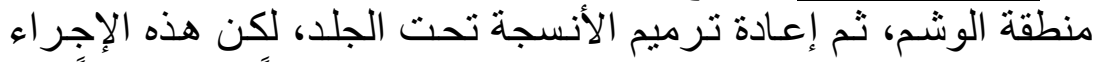

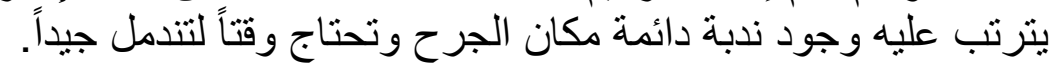

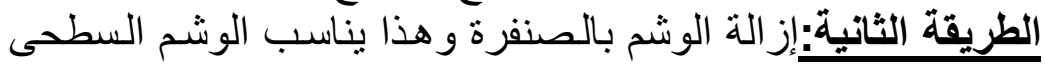

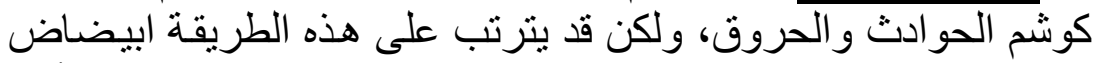

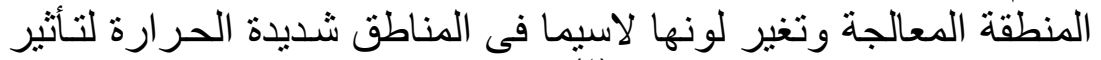

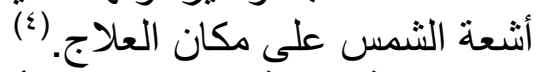
الطريقة الثالثة: إز الة الوشم بأنثعة الليزر حيث يتم تدمبر الأنسجة

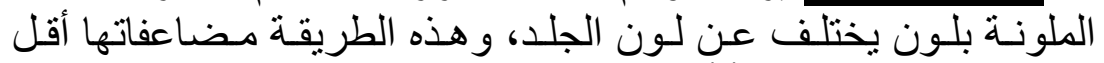
ولكنها تحتاج إلى وقت

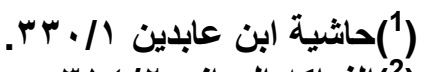

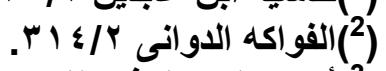

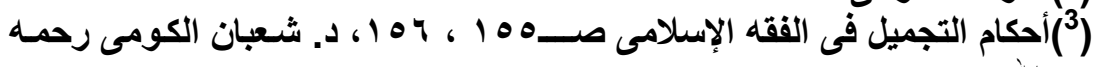
الله.

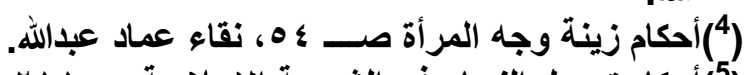

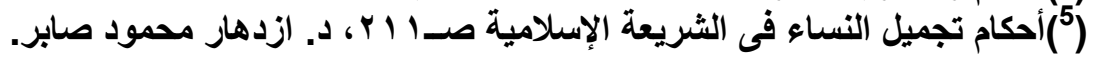
INOV 


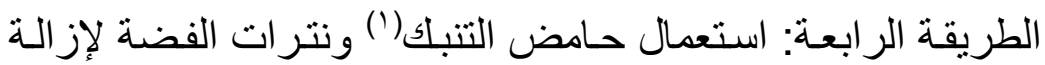

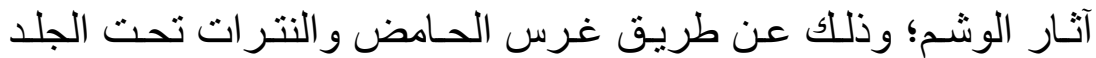

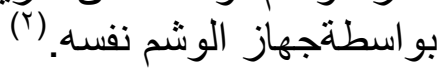

(1) هو مركب حمضى يعد من المركبات متعددة الفينول ذو حامضية قليلة قليلة

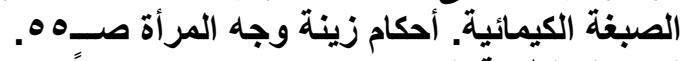

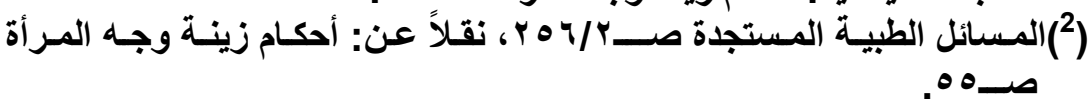

$$
1 \wedge 01
$$




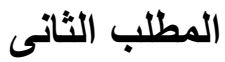 \\ التقليج ( الوشر ) الثفى )}

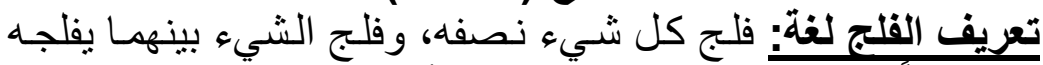

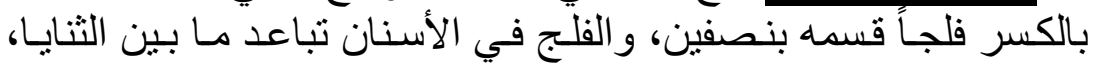
و الرباعيات خلقة فإن تكلف فهو التفليج، يقال: رجل أفلج الأسنان وامرأة التان

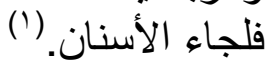
أن التفلبج اصطلاحاً:

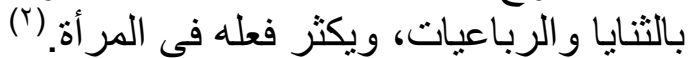

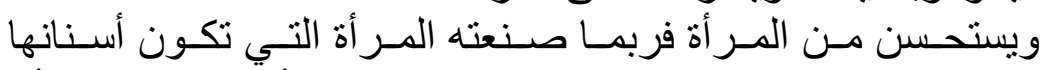

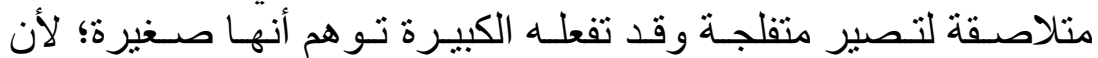

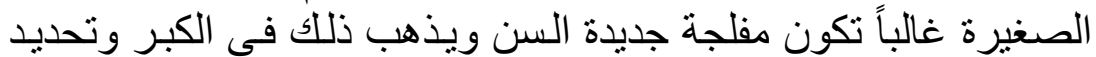

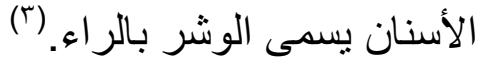

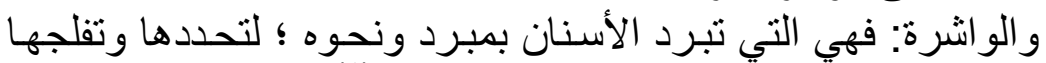

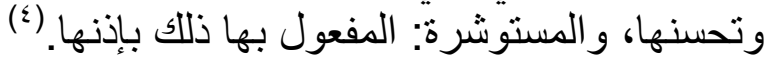

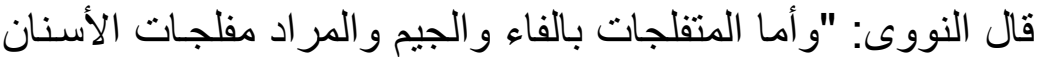

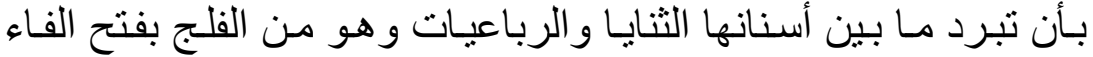

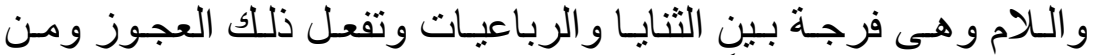

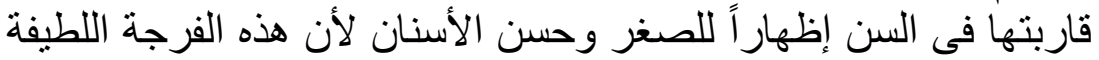

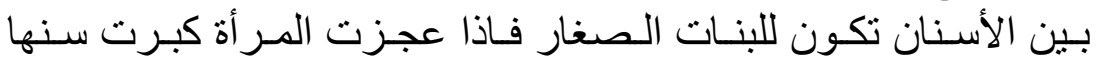

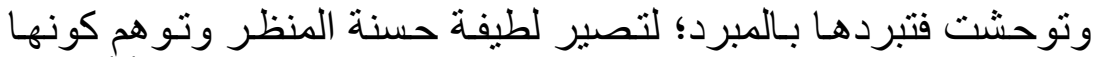

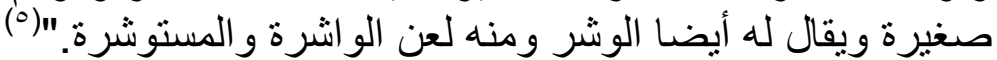

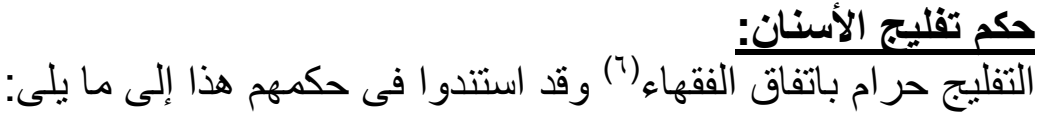

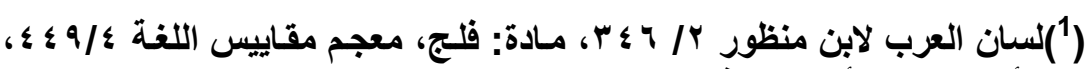
لأبي الحسين أحمد بن فارس بن زكريا، تحقيق عبد السلام محمد هارون، طا لإل

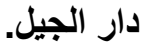
(3)

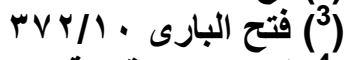

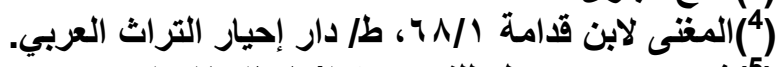
)

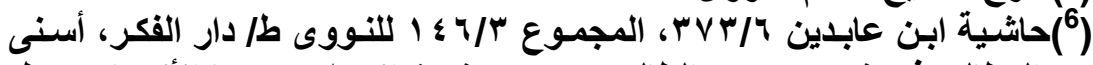

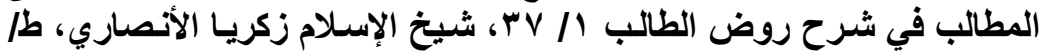
1109 


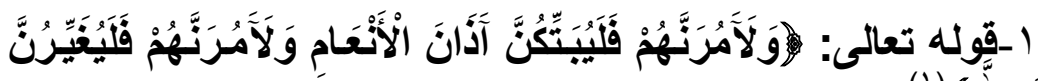

خَلْقَ اللَّ

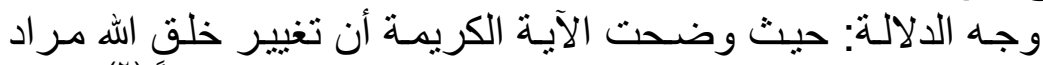

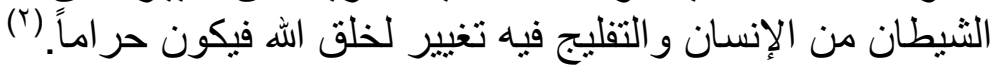

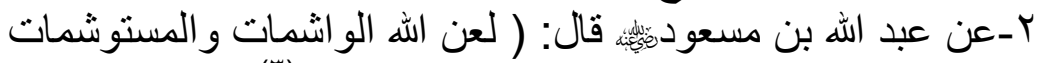

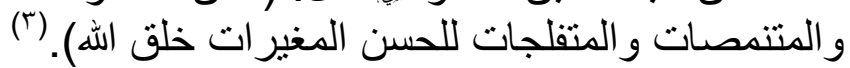
وجه الدلالة من الحديث:

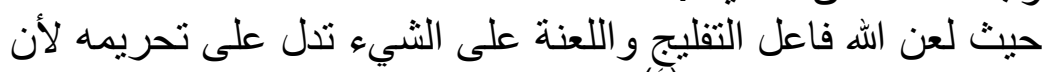

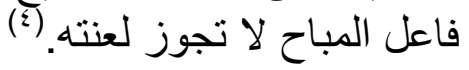

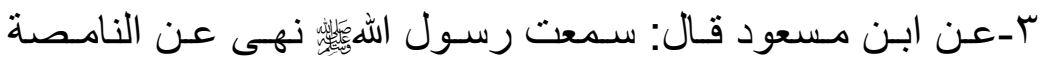

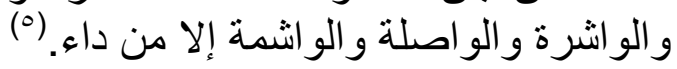

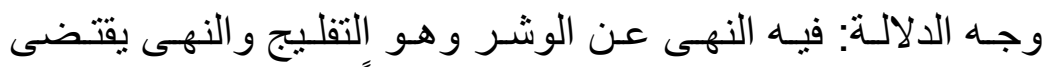

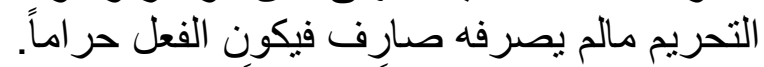

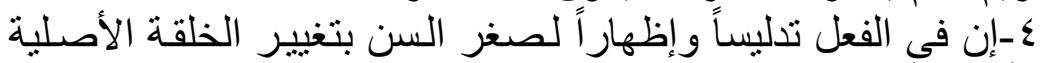

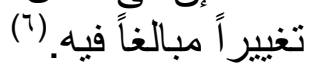

0ـالضرر الذى يسببه التفليج و الوشر للأسنان، فقد خلق اله الإنسان

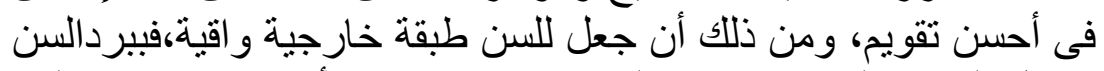

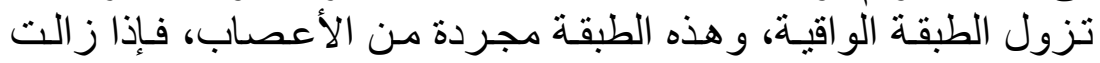

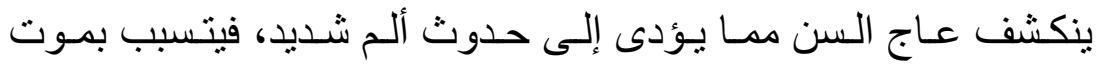

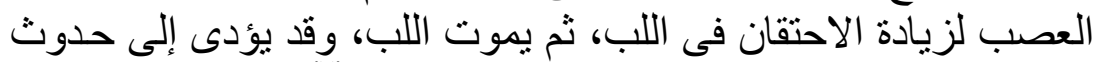

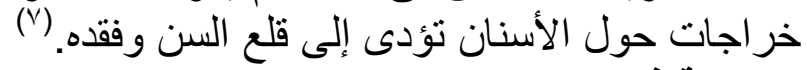
العلة فحى تحريم التقليج:

دار الكتب العلمية، الطبعة: الأولى، تحقيق: د. محمد محمد تامر، كثاف القتاع

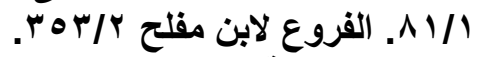

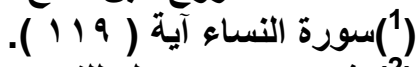

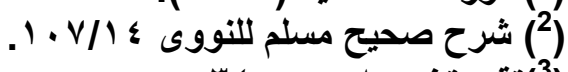

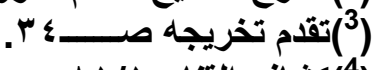

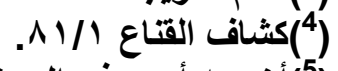

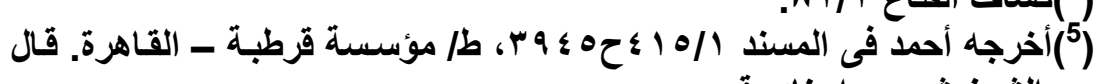
الثيخ شعيب: إسناده قوى أمثل

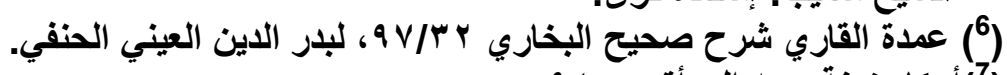

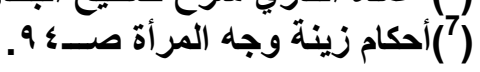


اختلفو ا فى العلة فقيل: لأنه تغيير لخلق الله تعالى، وقيل: لأنه تزوير،

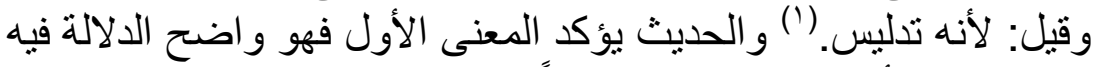

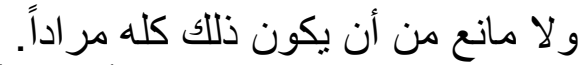

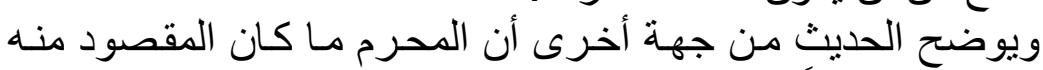

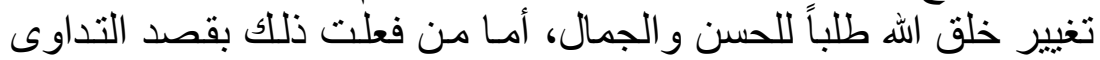

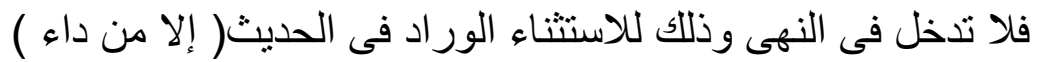

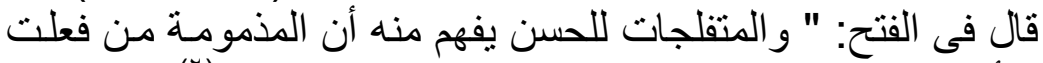

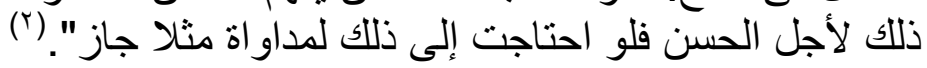

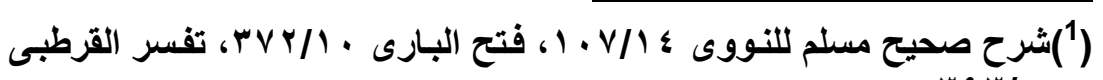

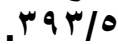
(2) فتح البارى مرجع سابق. يراجع: أحكام جراحة التجميل د. شبير صــه جهـ، فقه القضايا الطبية المعاصرة صدو بهاه. $|\wedge 7|$ 


\section{المطلب الثالث الثمان \\ ثقب أذن المرأة لتعليق الحلق المقاء}

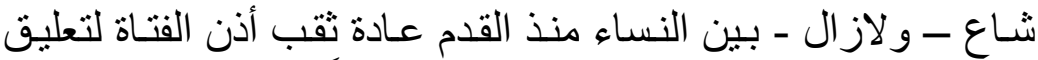

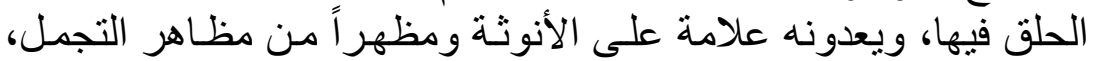
فهل يجوز هذا الفعل؟ فئه اختلف الفقهاء فى هذه المسألة على مذهبين:

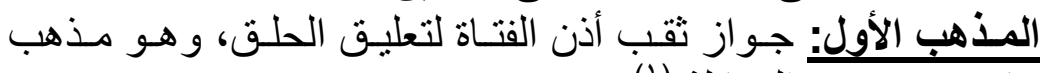

الأحناف، وجمهور المول: الحنابلة. (')

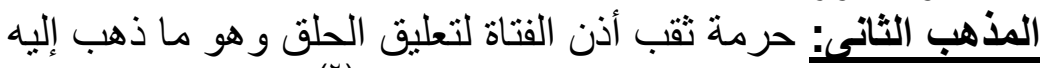

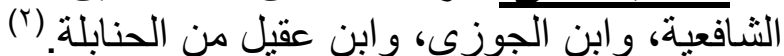

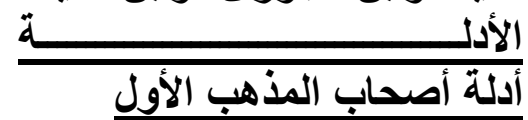

استدلو ا على مذهبهم بأدلة من الأول السنة و المعقول: أولاً: أدلتهم من السن مذهنة

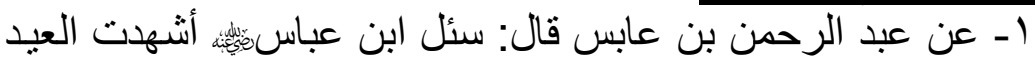

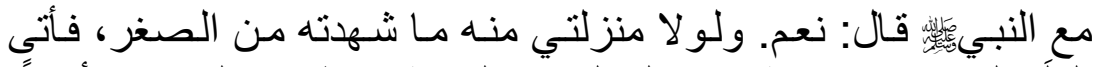

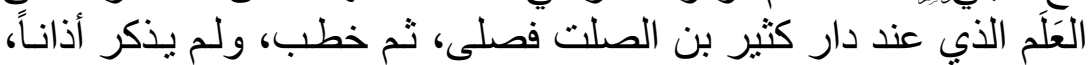

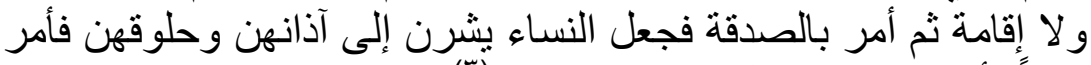

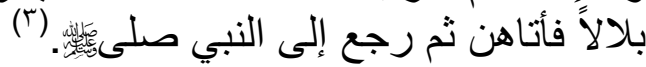

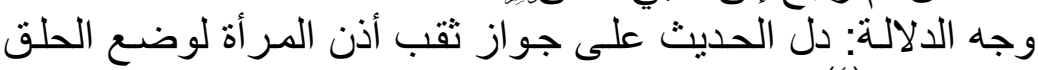

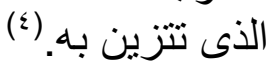

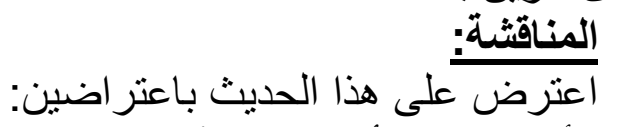

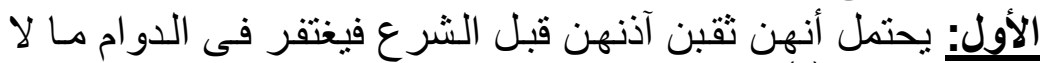

يغتفر فى الابتداء. (ن)

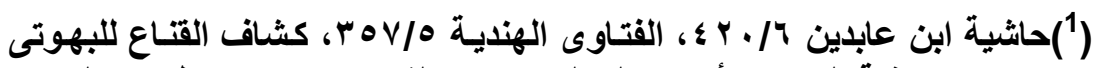

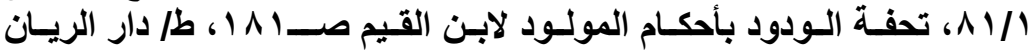

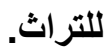

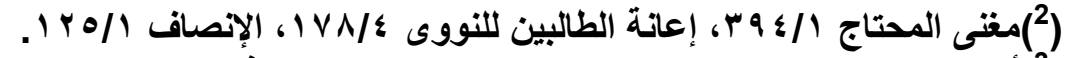

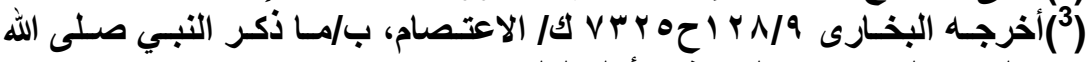
عليه وسلم وحض على البخ اتفاق أهل العلم. 
الثانى: لا يلزم من لبس الحلق ثقب الأذن لتعليقه بل يجوز أن يشبك

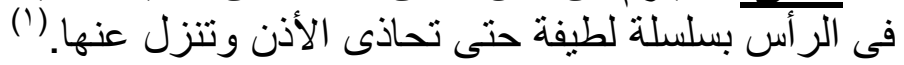

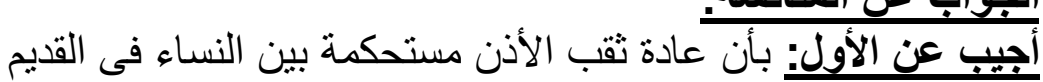

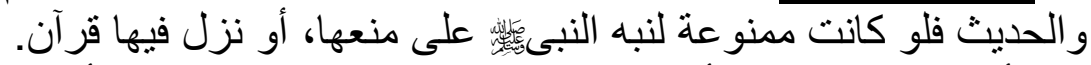

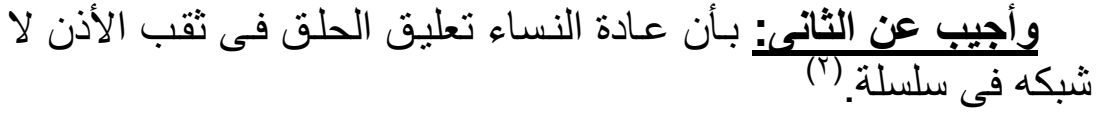

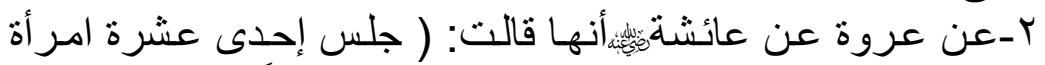

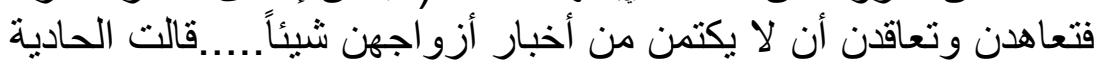

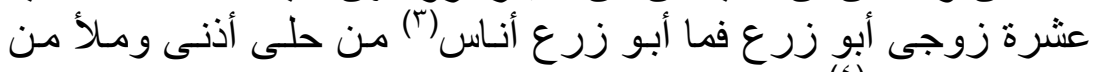

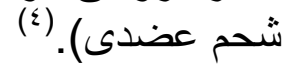

وجه الدلالة: حيث ذكرت المر أة هذا عن زوجها فيى معرض الثر المدح

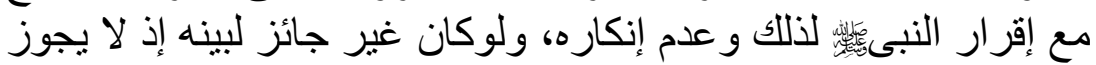

تأخير البيان عن وقت الحاجة.

المناقثية

تأخير البيان عن وقت الحاجة لا يجدي هنا لأنه ليس فيه تأخبر ذلك الكا

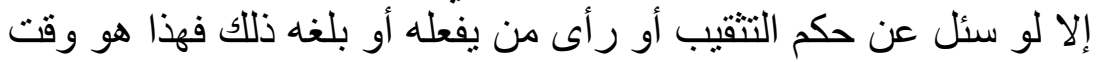

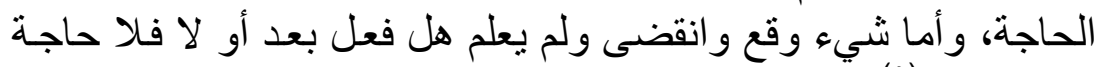

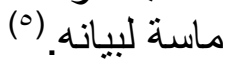

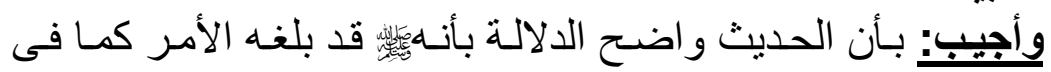

الحديث ولم ينكره فل الحل على الجواز.

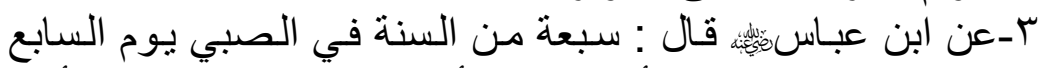

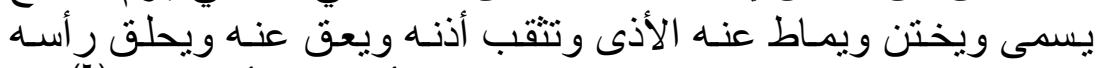

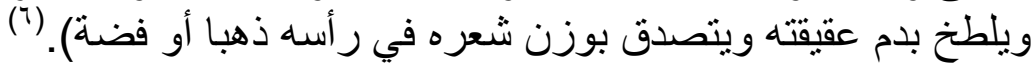

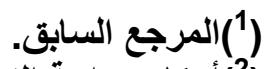

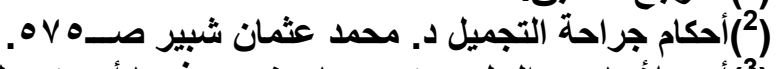

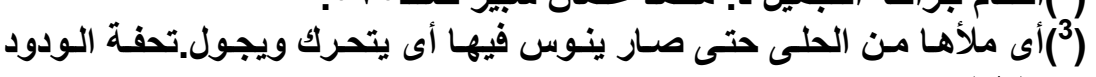
111

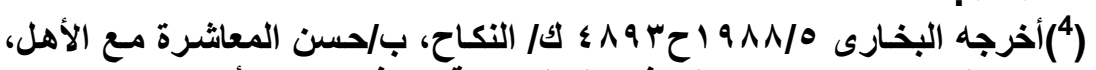

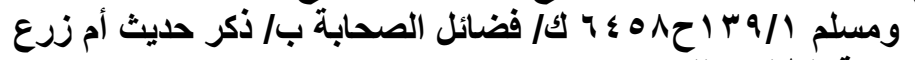

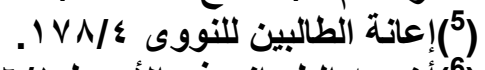

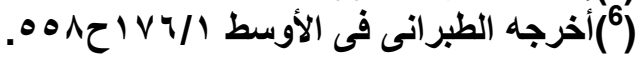

1Nтt 
وجه الدلالة: حيث بين الحديث أن من السنة ثقب الأذن فيكون نصاً

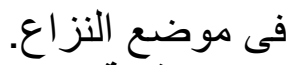

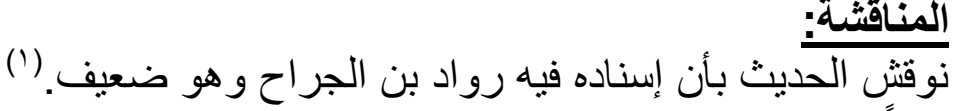
ثانياً: من المعقول المدئ

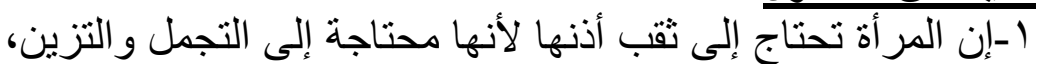

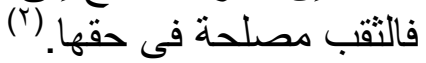
r-إن العرب كانو ا يفعلونه ولم ينكر عليهة عند مجىء الشرع فدل

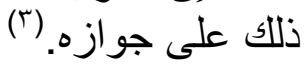

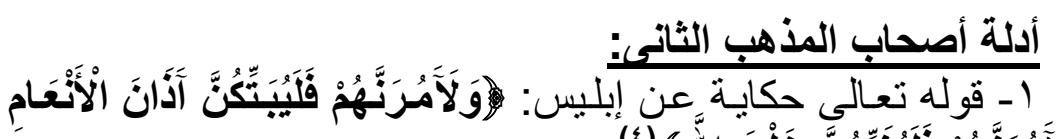

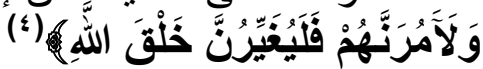

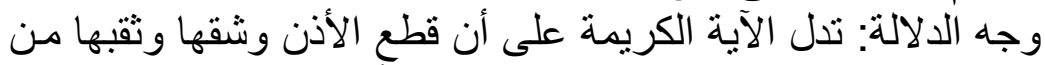

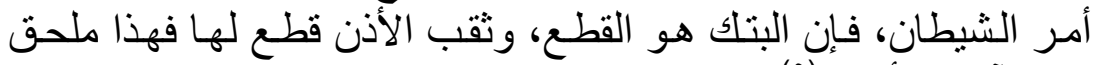
بقطع آذان الأنعام. (0) فئنان

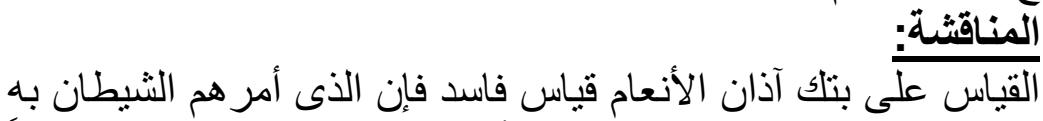

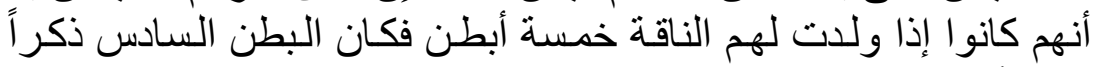

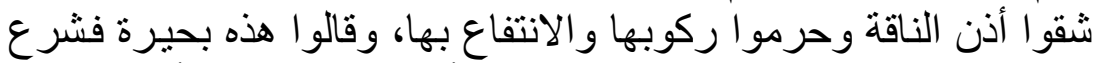

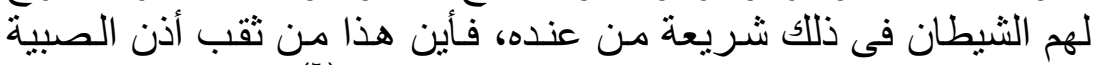

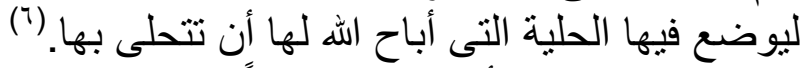

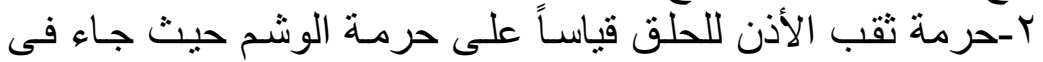
أحكام النساء:" إنماء قال أبو الوفـاء بن عقبـل: والنهي عن الوشـم تنبيـه على منـع ثقب الآذان. 
قال المصنف رحمه الله: قلت: وكثير من النساء يستجزن هذا في حق التق

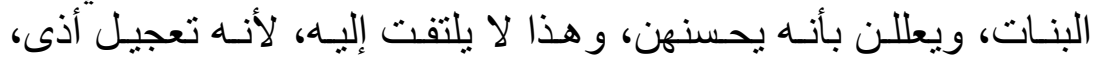

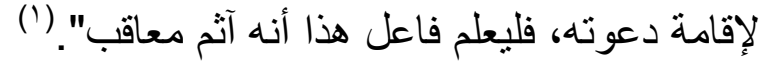

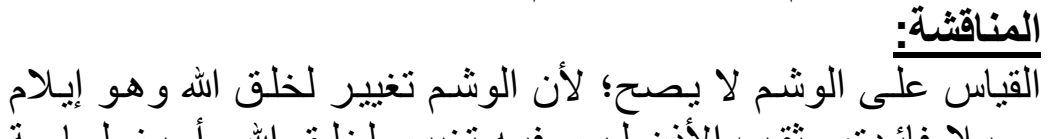

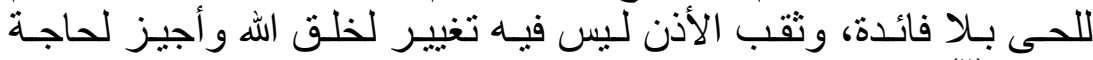

كَ-إن الثقب جرح مؤلم لا يجوز فعله إلا لحاجة مهـة والتحلى ليس

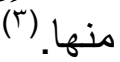

ونوقش هذا: بأن التعلى حاجة مهمة عند النساء وفى منعهن منـهـ

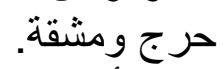
ـ ـأنه تعجيل أذى لا فائدة منه فلا يشر ع فعله.

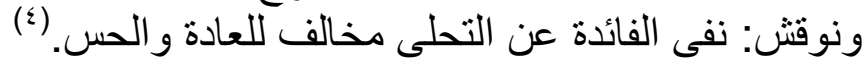

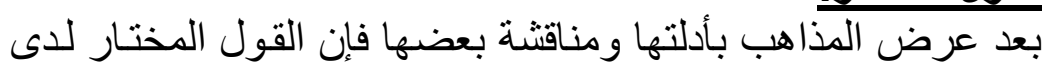

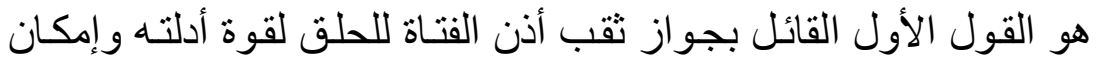

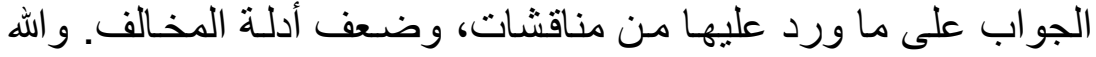




\section{المطلب الرابع \\ حكم قطع الزوائد الخِلقية}

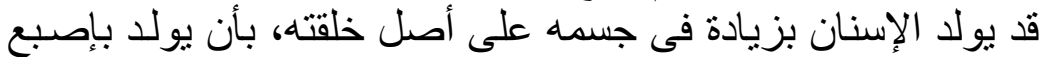

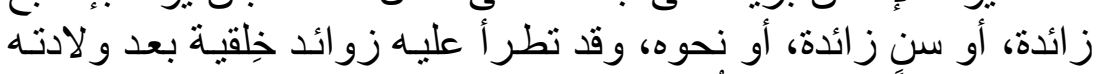

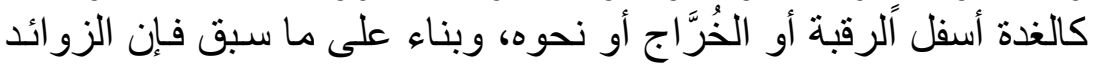
تنقسم إلى قسمين:

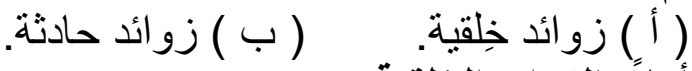

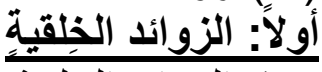

$$
\begin{aligned}
& \text { و هذه الزو ائد الخلقية تنقسم إلى قسمين: } \\
& \text { و هذأ زوائد يصاحبها ألم يدعو إلى قطعها: }
\end{aligned}
$$

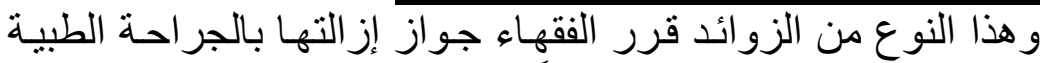

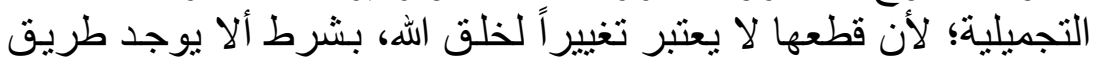

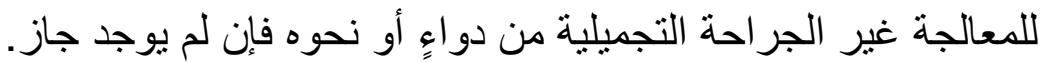

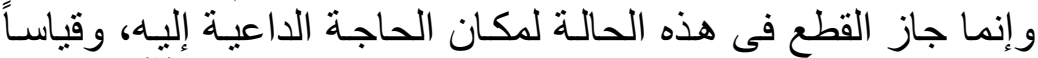

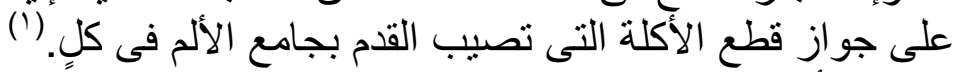

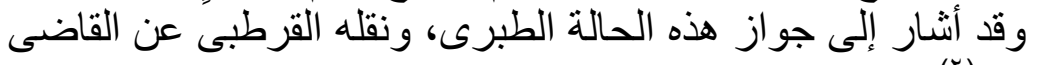

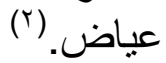

قال الحافظ ابن حجر نقالً عن الإمام الطبري: "لا يجوز للمر أة تغيير

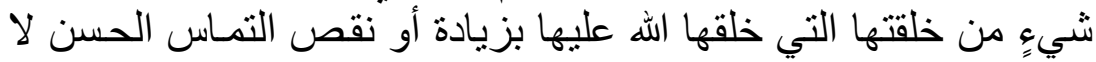

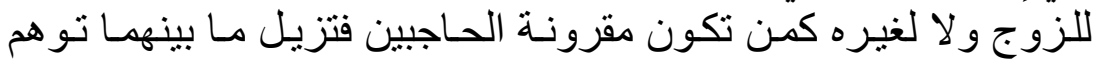

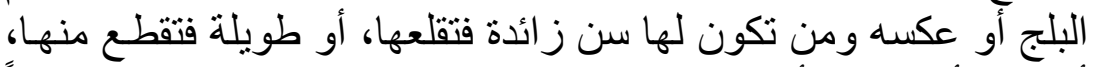

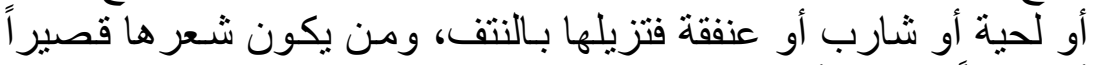

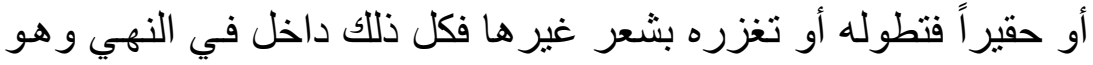

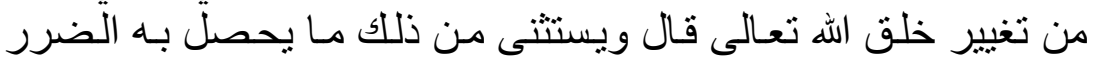

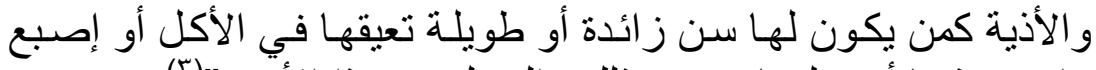

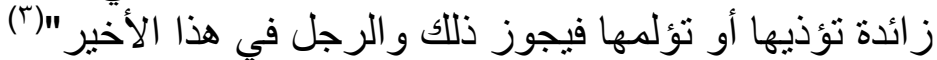

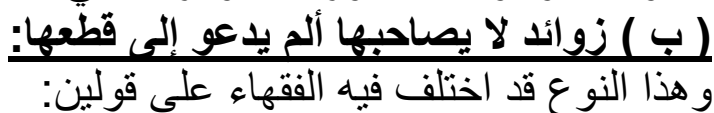

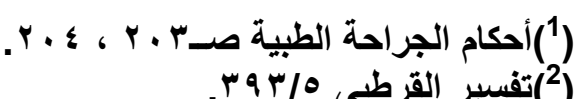

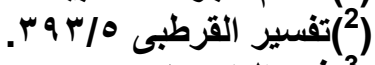

(3) 1 1 
القول الأول: جواز إز الة العضو الزائد في هذه الحالة وهو مذهب الإبه

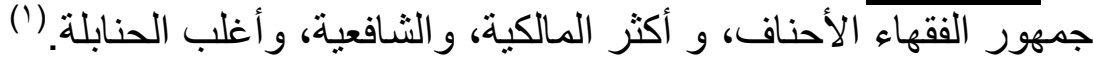

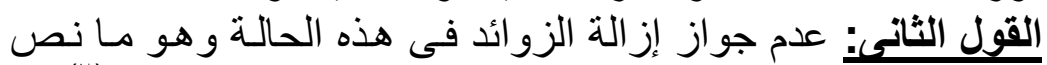

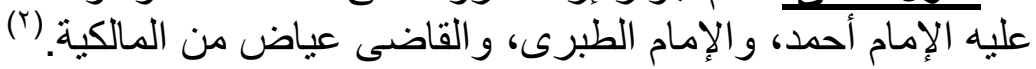

يرجع سبب الخلاف فى هذه المسألة إلى عدة أمور منها:

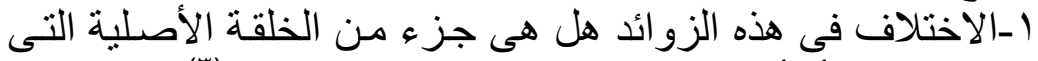

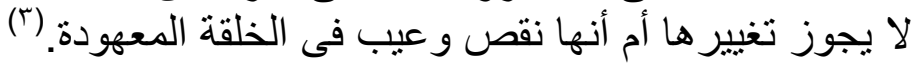

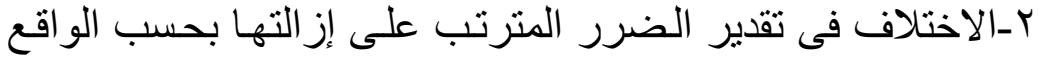

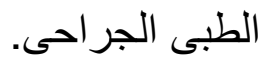

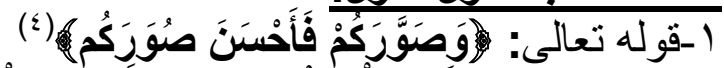

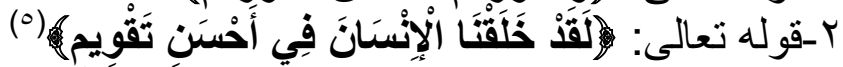

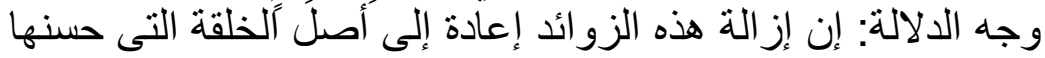

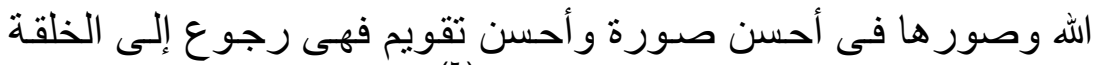

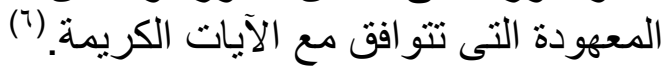

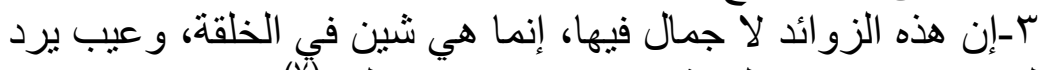

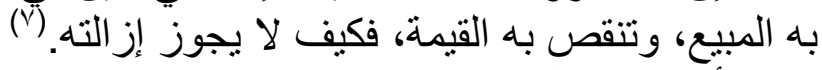

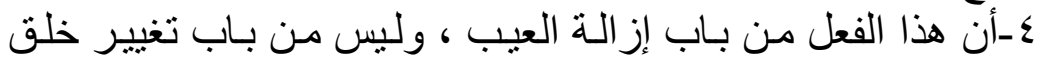

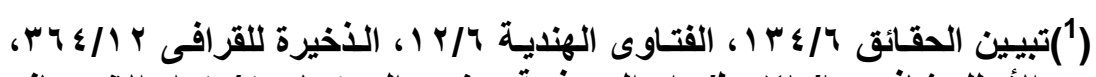

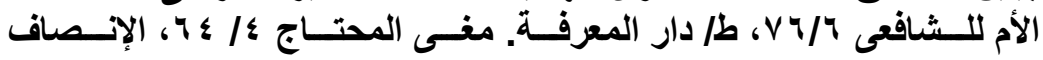

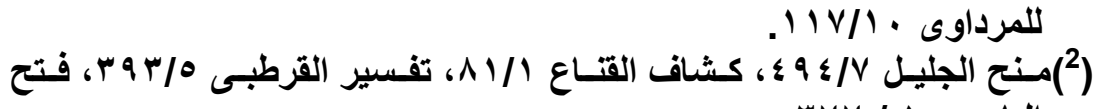

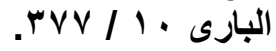

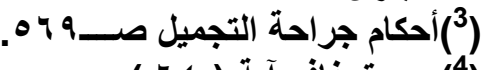

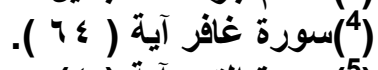

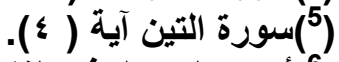

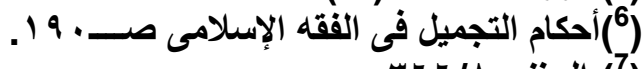
INTV 


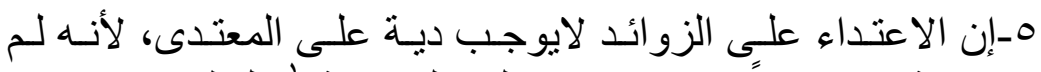

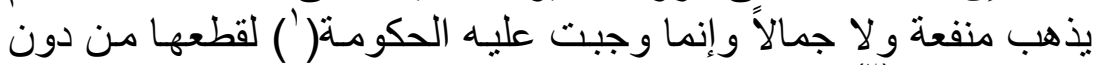
إذن صاحبها. (r)

جاء فى حانشية ابن عابدين ما نصاه:

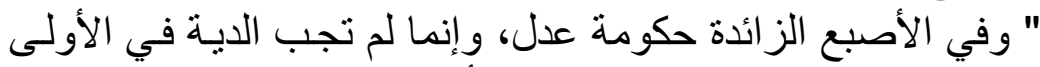

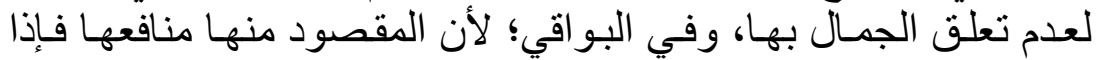

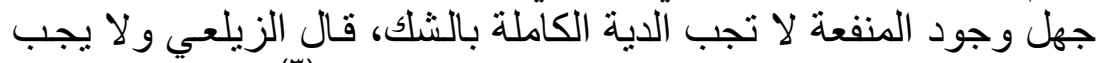

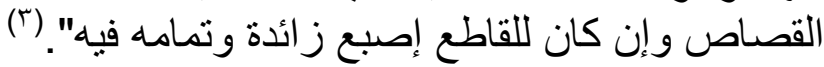

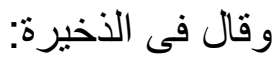
" و إن كانت الز ائدة- أى الإصبـع- ضـعيفة فقطعت يده لم يزد في في

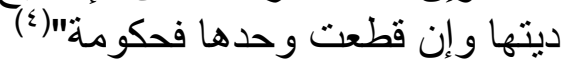
ونوقشن هذا الاستدلال بأن إسقاط بعض الفقهاء لضمان هذه الإصبع

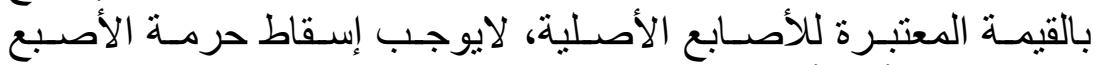

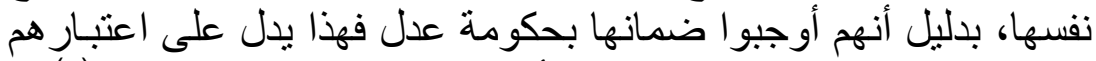

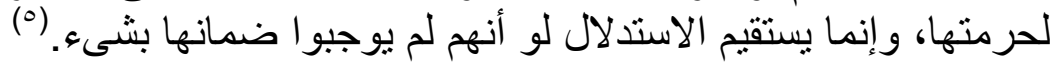

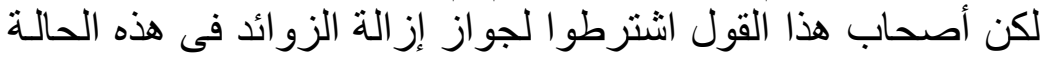

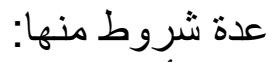
1أن تكون زائدة على أصل الخلقة المعهودة. r أن تؤدى إلى ضرر مادى أو نفسى لصاحبها.

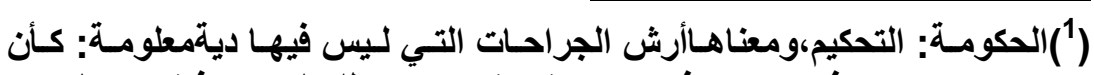

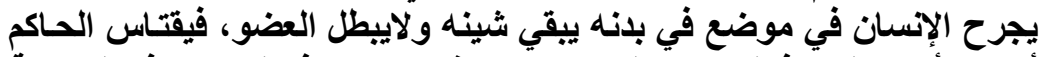

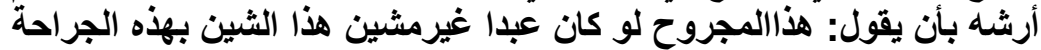

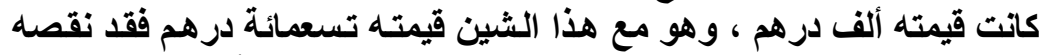

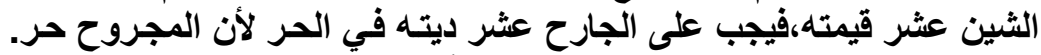

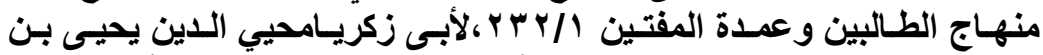

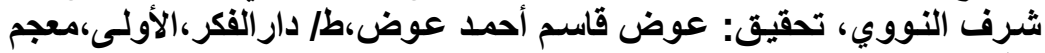

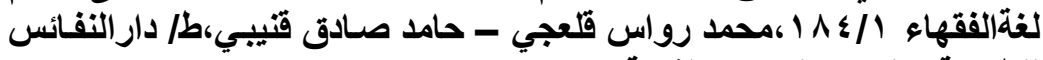
لإباعة والنشرو التوزيع، الثانية.

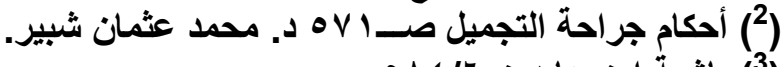
(3)

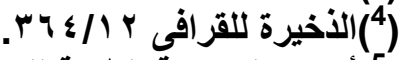

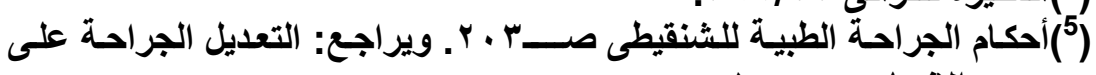

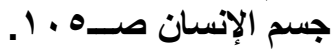




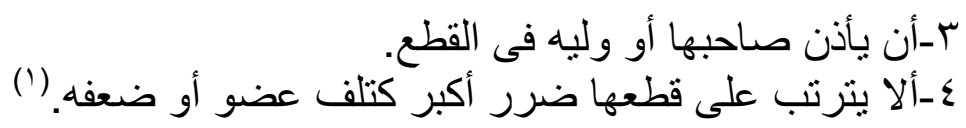

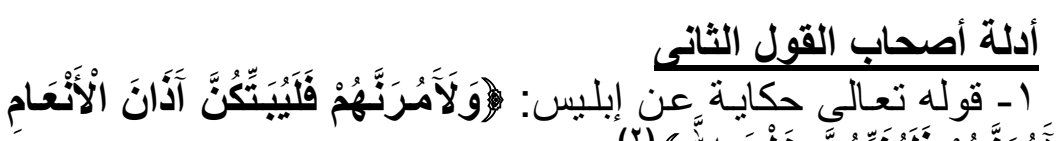

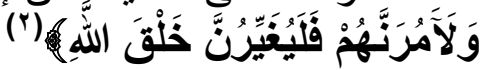

وجه الدلالة: إن إزالة الزوائد الأل من جسم الإنسان تغيير لخلق الله فلا

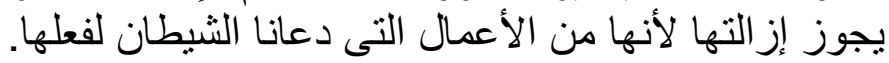

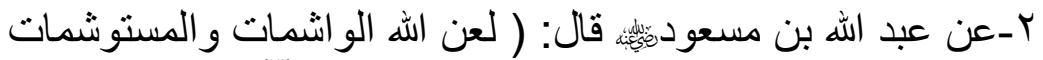

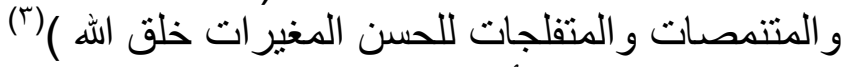

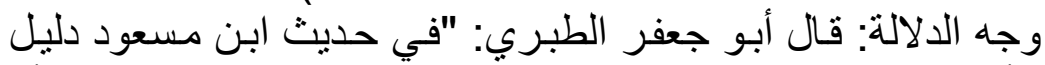

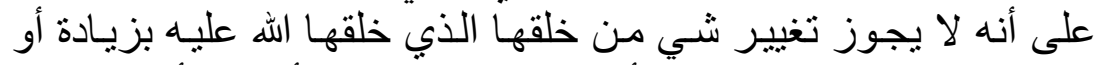

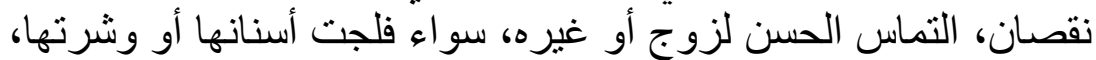
أو كان لها سن زائدة فأز التها أو أسنان طو ال فقطعت أطر افه."((£)

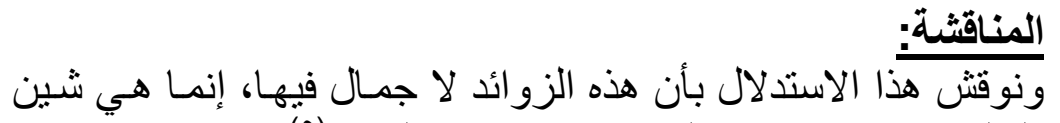

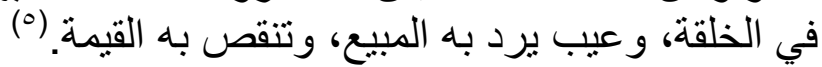
القول المختار: القولئ

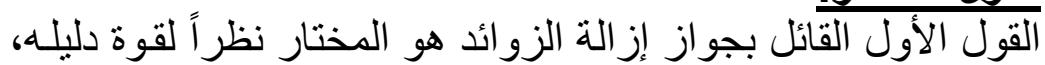

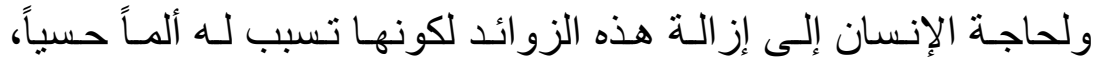

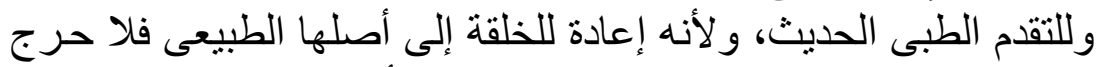

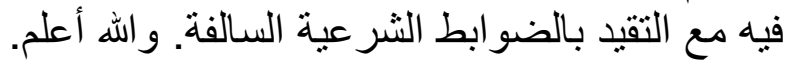

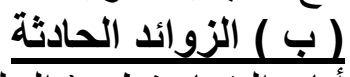

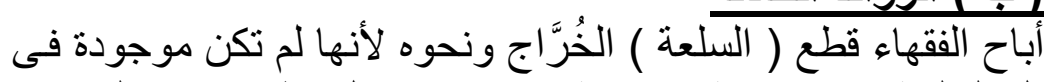

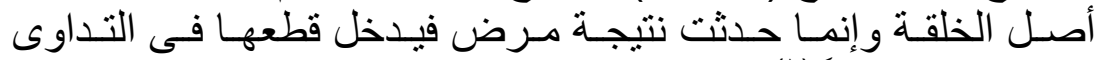

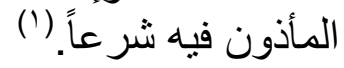

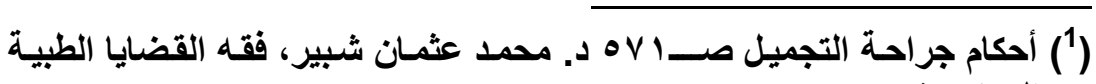

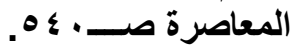

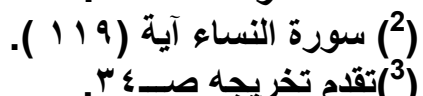

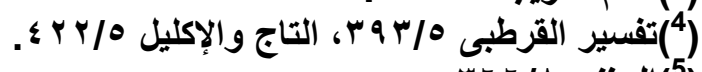
1199

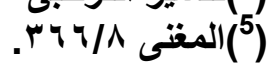




\section{نماذج من العلميات التجميلية الجراحية الحديثة، وأحكامها}

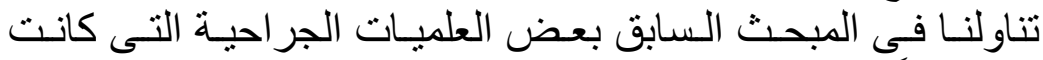

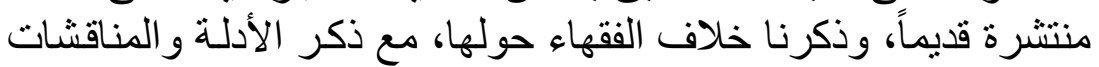

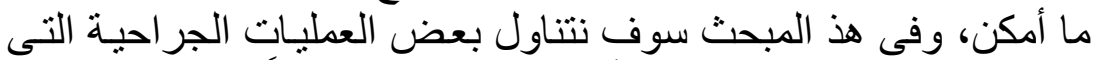

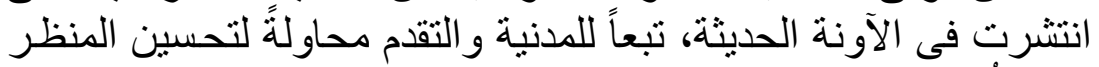

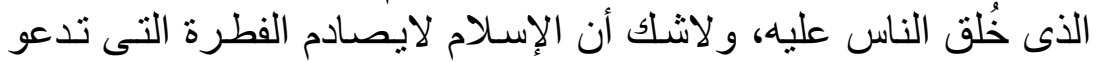

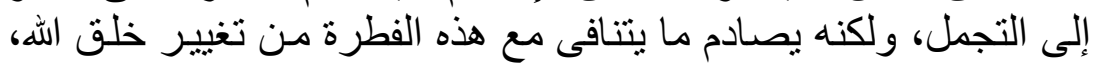
لذا يمكن اعتبار" تغيير خلق الله" هو الضابط المتفق عليه الفيه عند الحديث

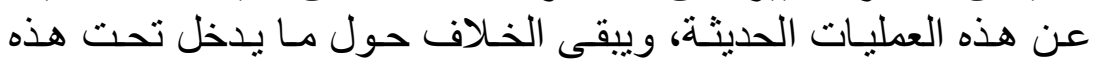
الضابط من العمليات وما لايدخل تحنى تحتها. وسوف نتناول هذا المبحث فى تسعة مطالب:

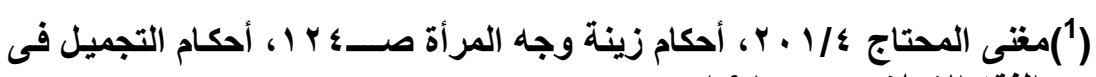

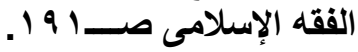
INV. 


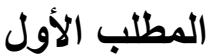 \\ جراحة تغيير الجنس (') الاول}

و المر اد بالتحول الجنسى: "شعور بالتناقص يعيشه الشخص كمعانـاة

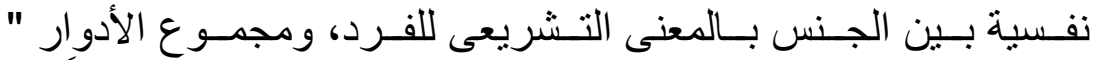
الوظائف" الجنسية التى تنتمى إلى الجنس الآخر سواء كان راغباً فى الإدى

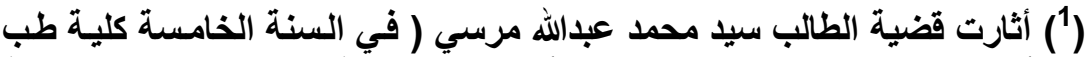

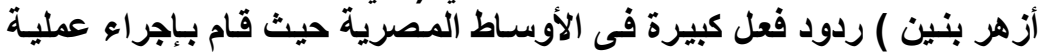

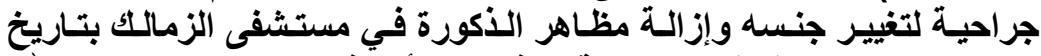

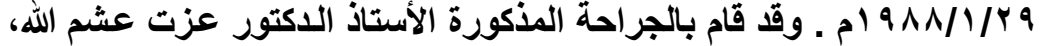

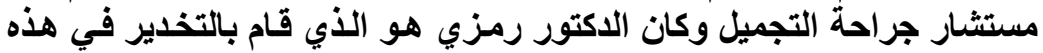

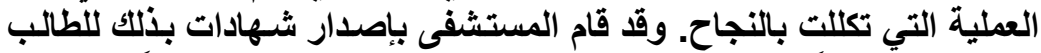

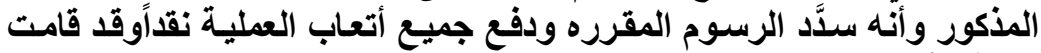

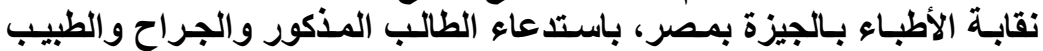

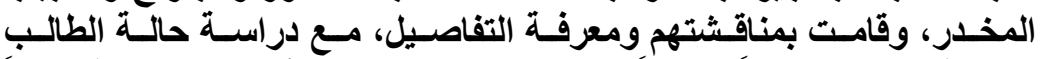

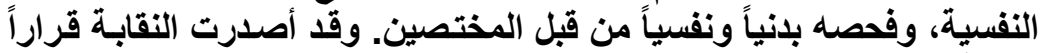

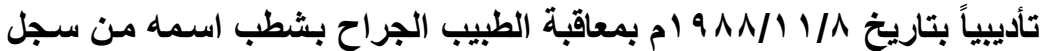

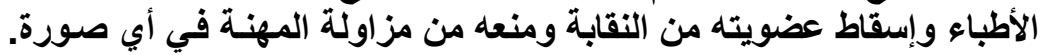

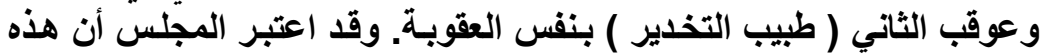

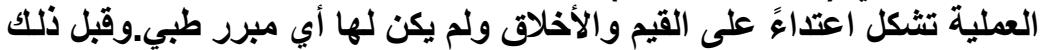

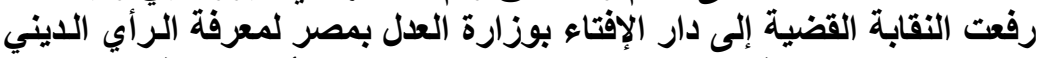

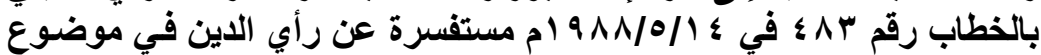

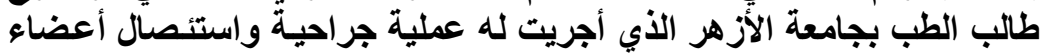

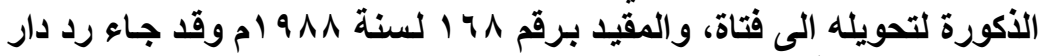

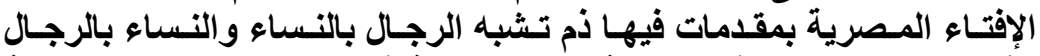

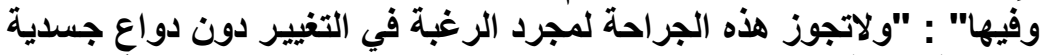

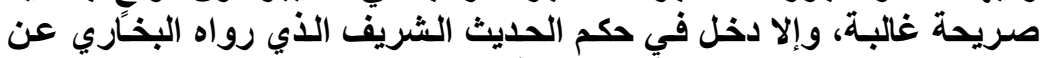

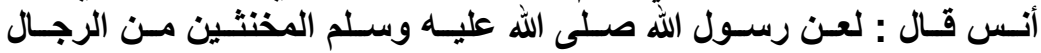

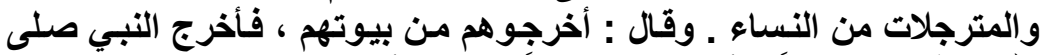

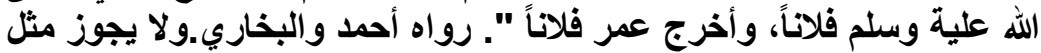

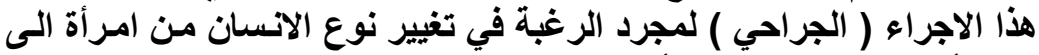

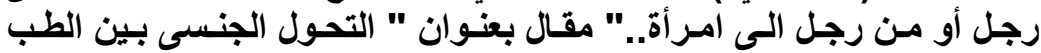

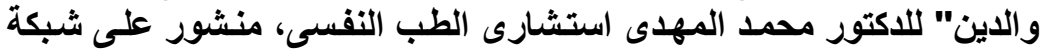
ت

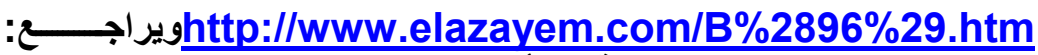

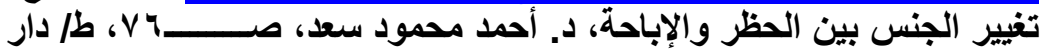

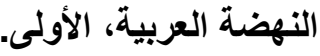


أداء تللك الأدوار أم كان بشعر بها كعنصر من عناصر السلوك التلقائى

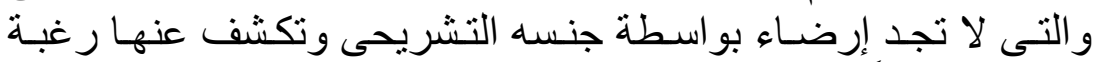

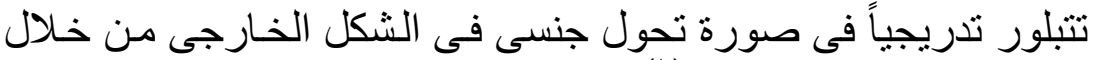
وسائل هرمونية وجرية احية" (')

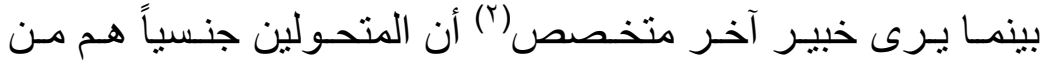

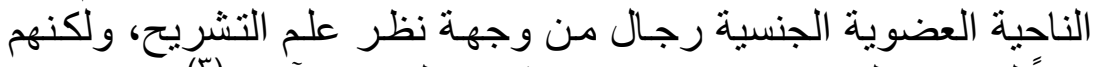

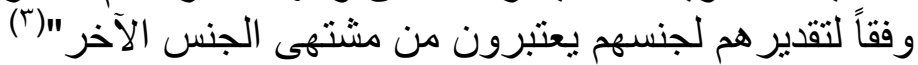

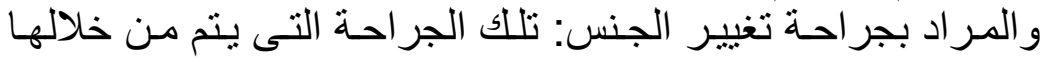

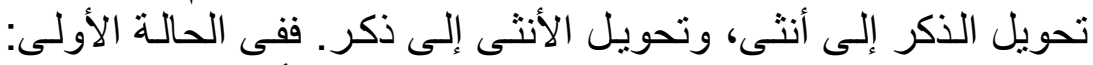

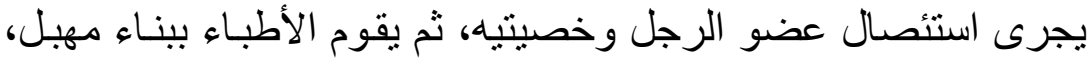
وفيى الحالة الثانيـة: يجرى استئصسال الثديين، و إلغـاء القناة التناسلية وتكبير الثديين. الأنثوية، وبناء عضو الرجل ( الذكر ).

وفى كلتـا الحسالتين يخضع الشخص الذى تجرى لـه الجر احـة إلى

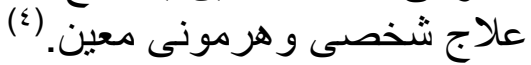

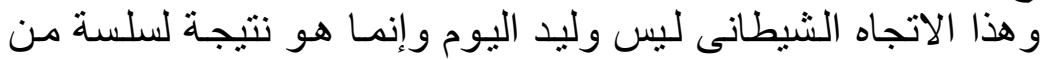

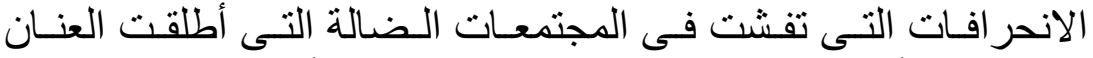

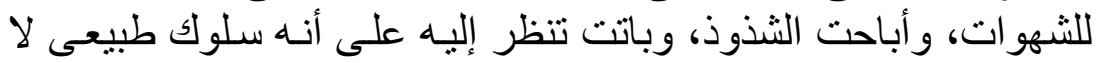

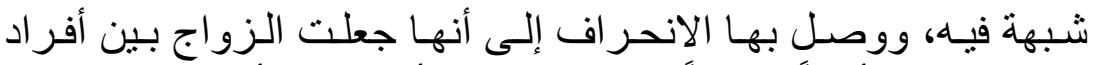

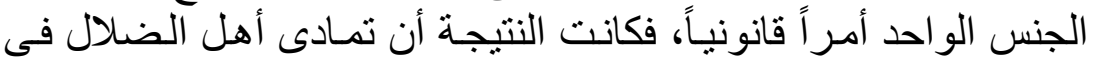

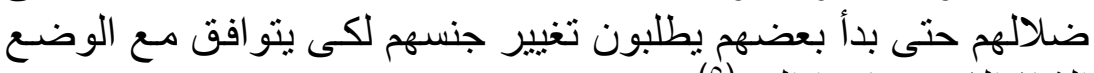

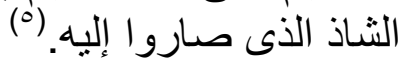

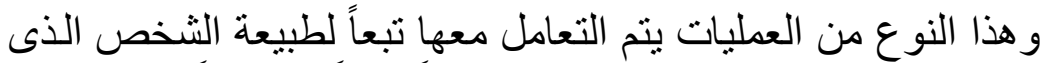

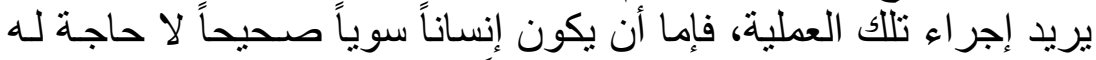

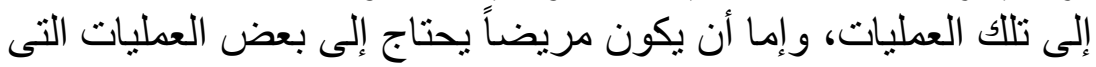

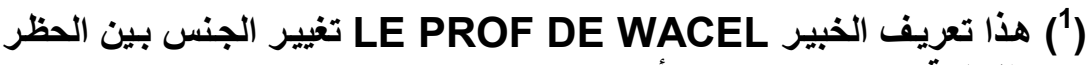
والإباحة صـــــــــــ 9 1، د. أحمد محمود سعد.

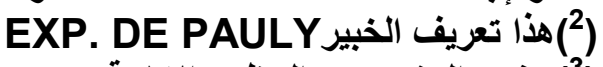

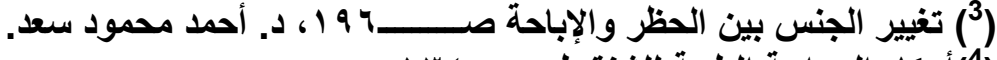

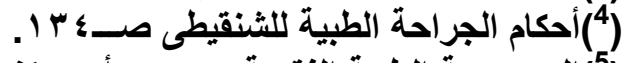

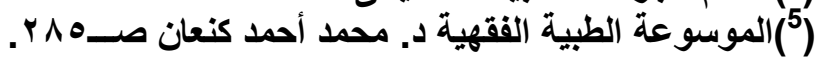
IAVY 
تعيد وضعه الجسمانى إلى طبيعته الصحية و المعتادة، وبنـاءً على ذلك فإن تللك العمليات تتنوع إلى اللى نوعين:

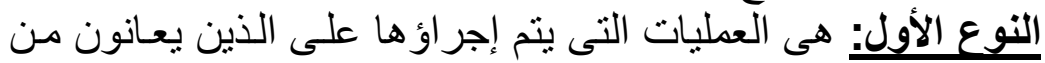

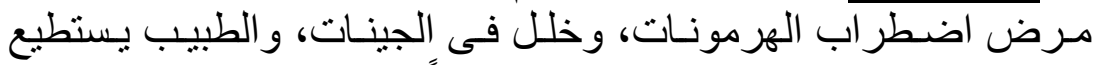

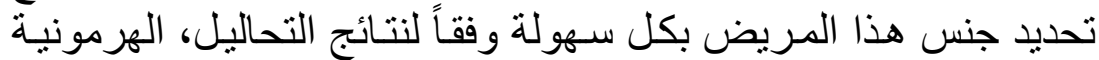

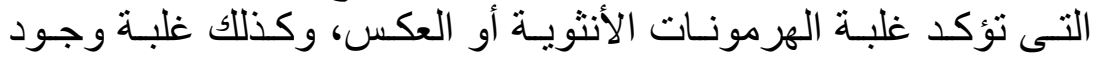

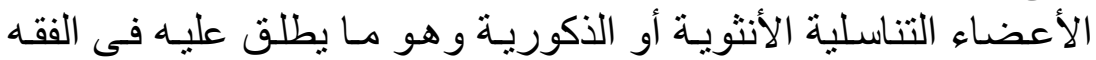

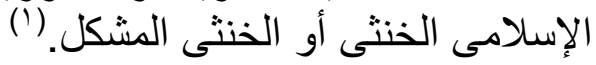

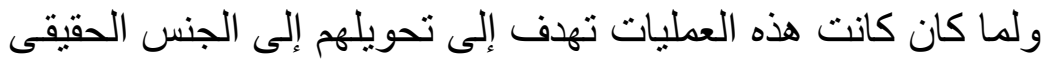

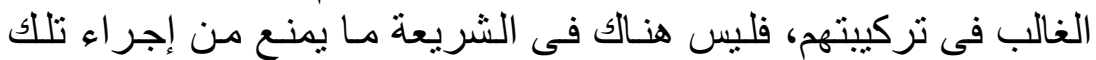

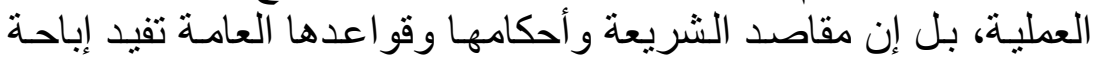

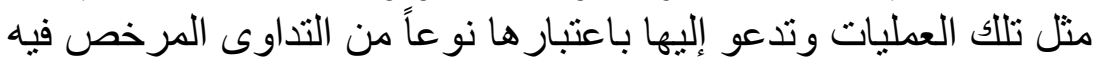

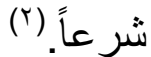

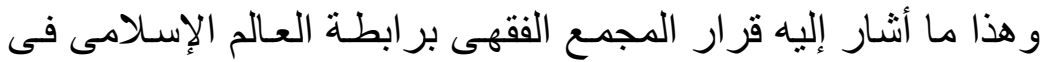
دورته الحادية عشرة المنعقدة بمكة المكرمة حيث الفي جاء فيه:

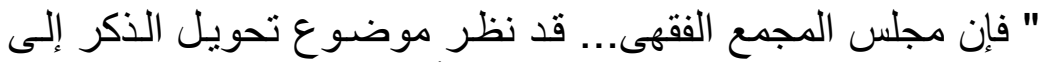

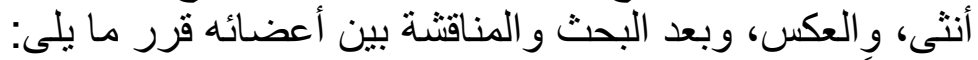

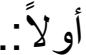

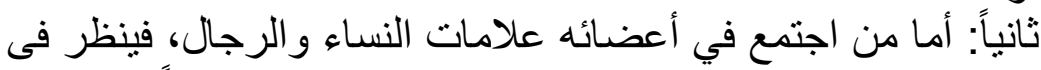

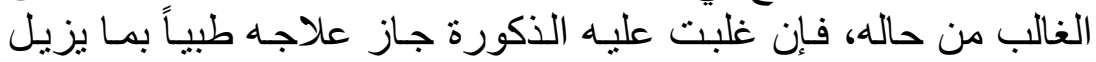

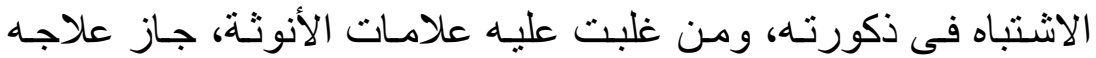

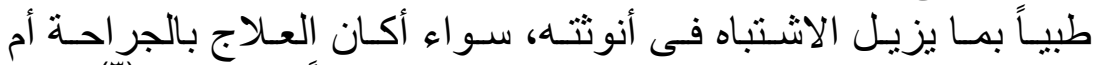

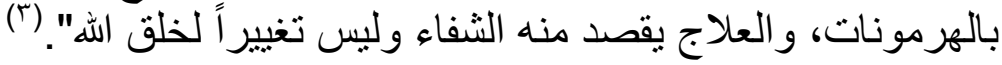

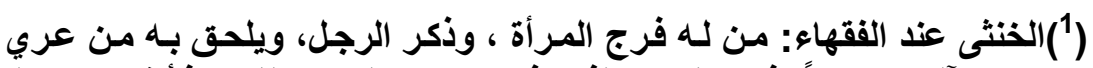

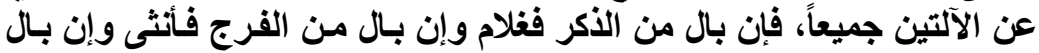

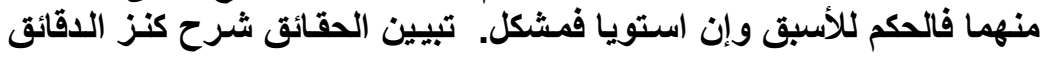

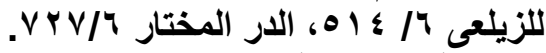

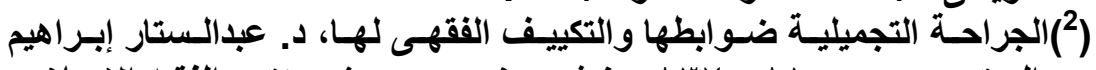

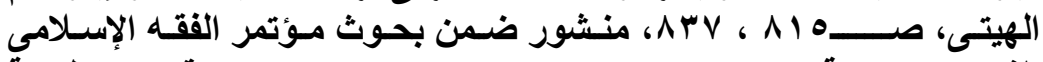

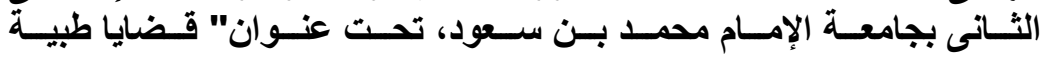
معاصرة". المجلد الثالث.

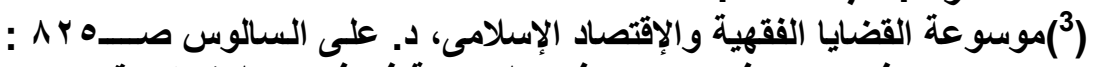

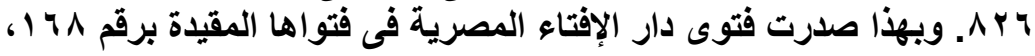




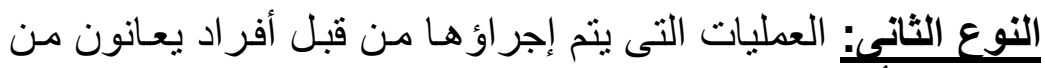

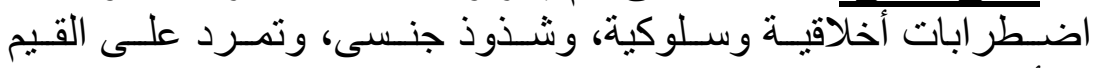

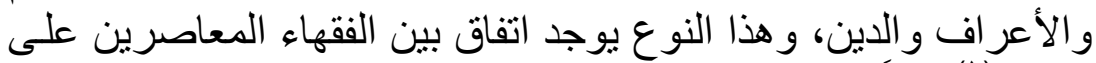
حرمته (1) وفقاً للأدلة التالية:

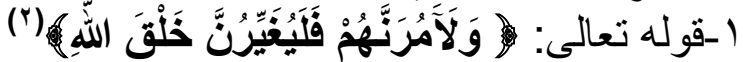

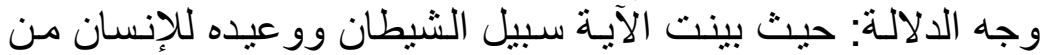

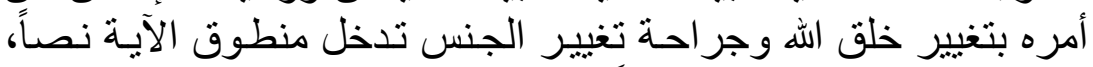

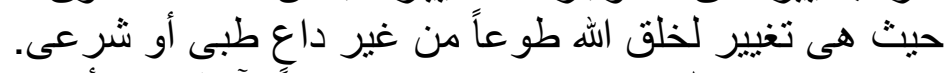

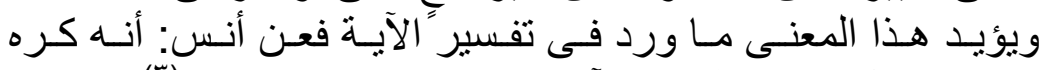

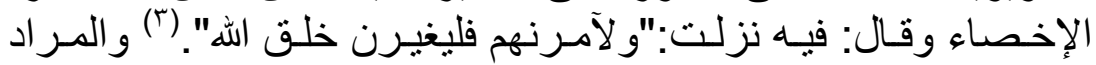

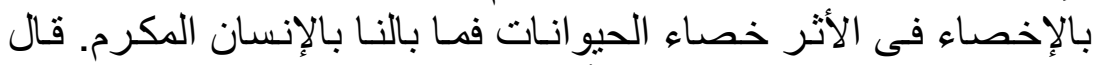

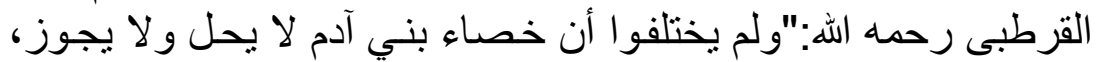

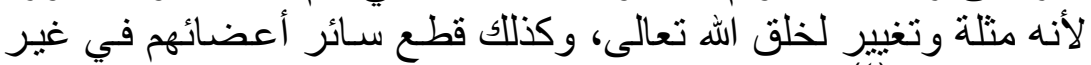

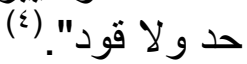

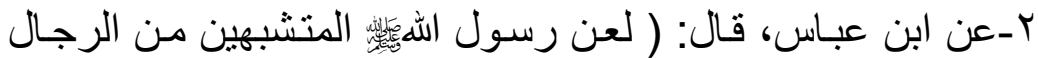

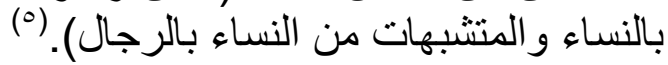

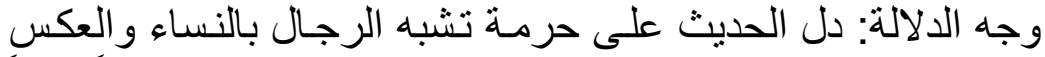

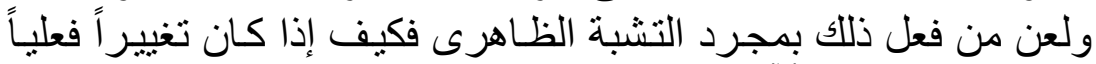

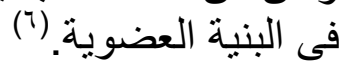

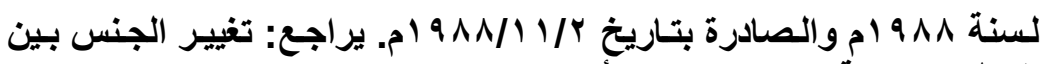

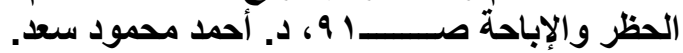

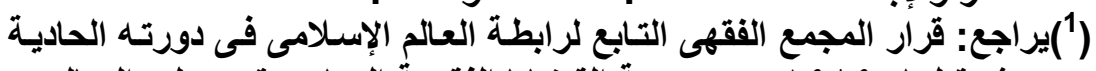

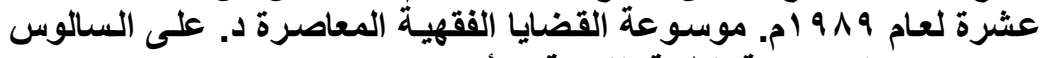

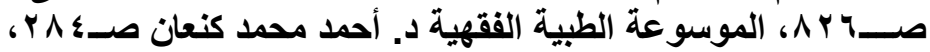

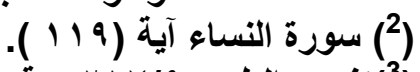

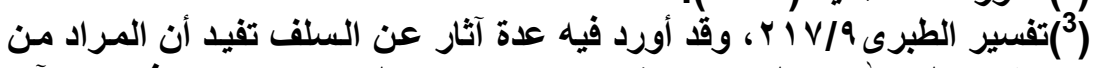

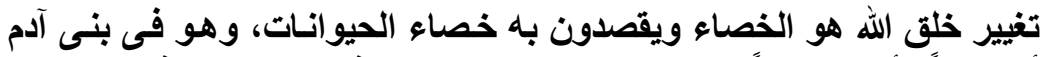

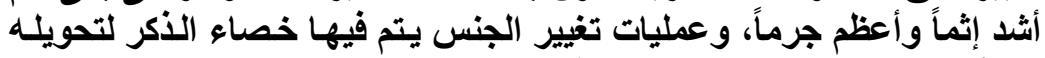

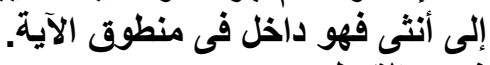
(5)

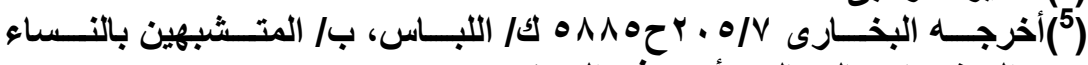

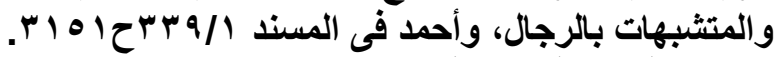

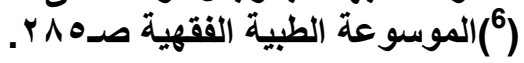


بـ-إن عمليات تحويل الجنس من المثلة المنهى عنها شرعاً والتى ورد فى النهى عنها بعض الأحاديث منها:

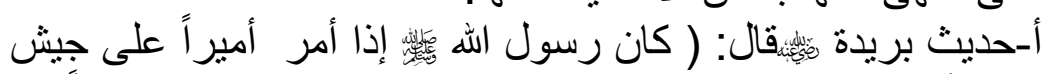

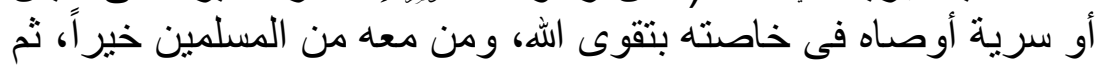

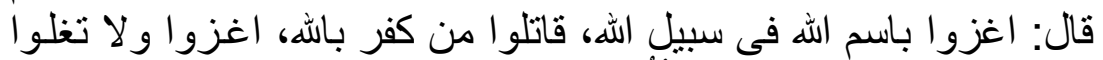

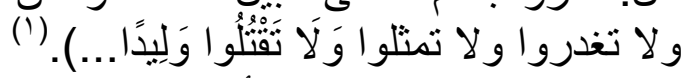

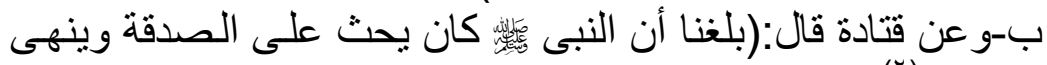

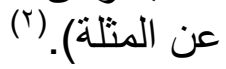
وجه الدلالة: إذا كان جدع الأنف وقطع الأذن من الئلة فكيف بقطع

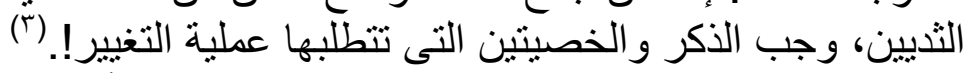

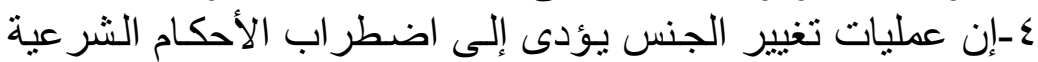

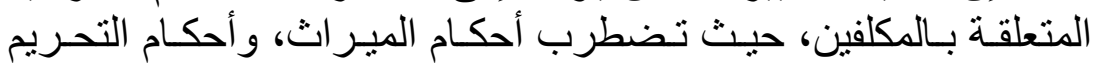

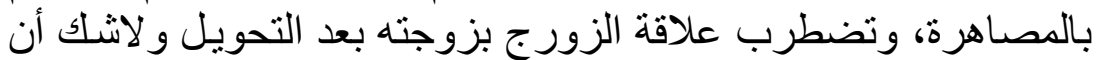
كل هذا مفاسد عظيمة تؤدى إلى التحريم. ه-إن عملية تحويل الجنس شكل من أنثكال الإفساد فى الأرض وضئ وهدم

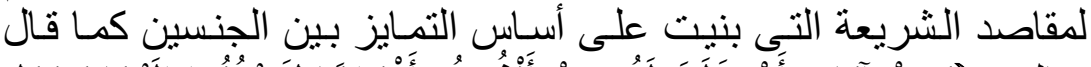

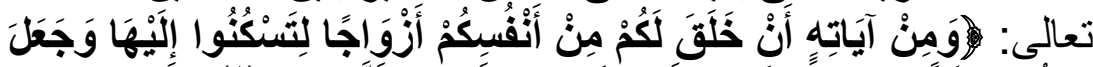

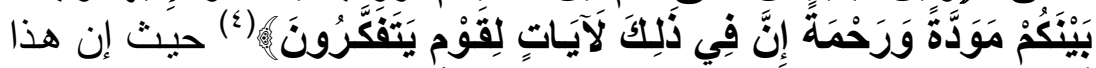

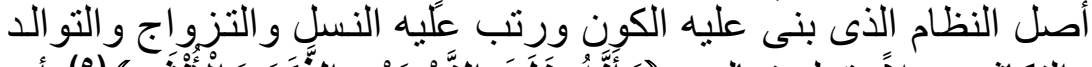

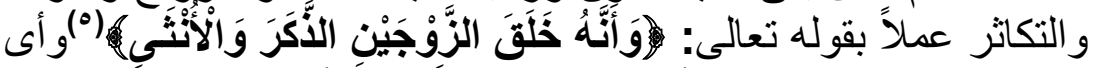

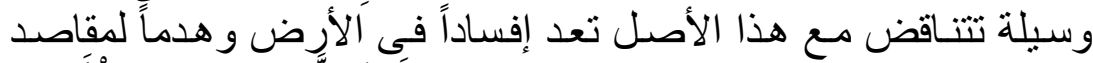

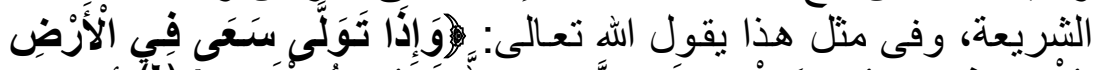

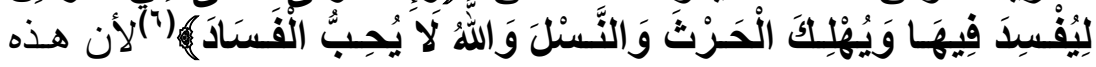
العطليات التى ربما تبدأ بحالات فردية سر وعان ما يتفاقم أمر ها، وتتحول

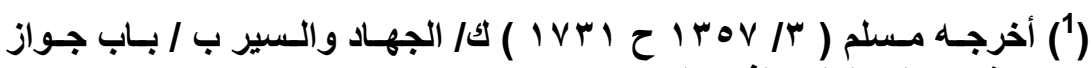

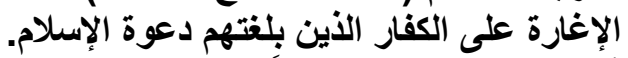

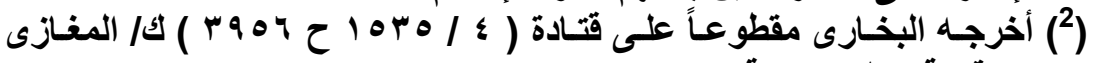

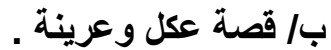
(3) الجراحة التجميلية ضسو ابطها والتكييف الفقهى لها، د. عبدالستار إبراهيم

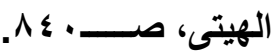

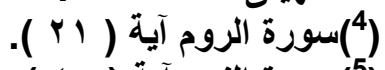

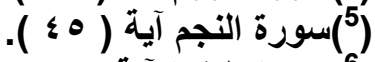




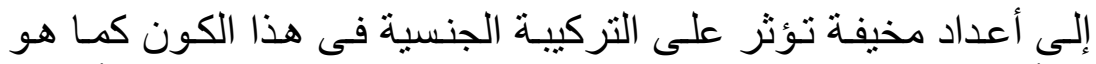

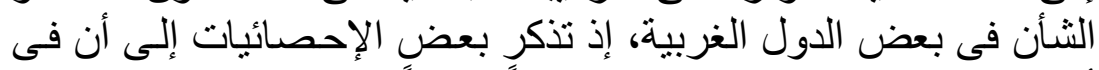

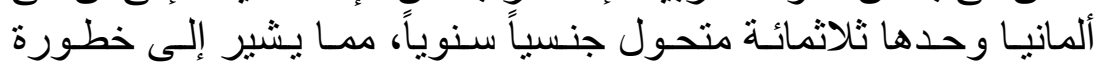

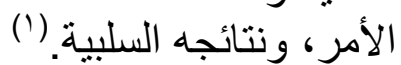

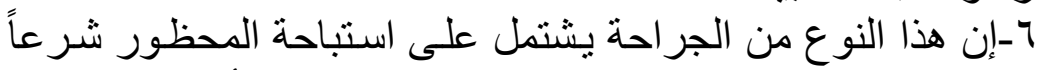

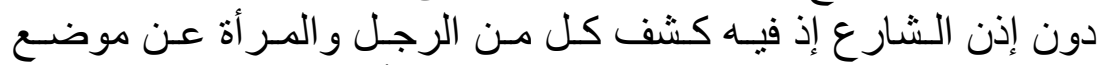

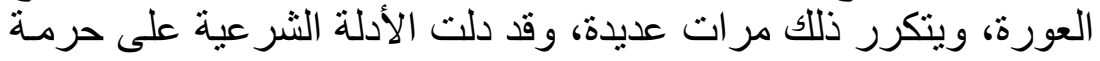

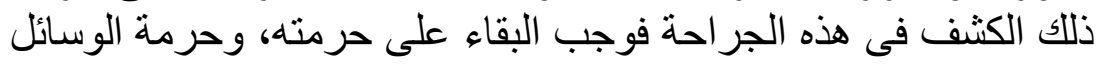

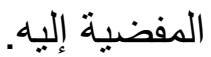

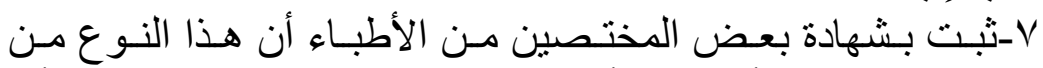
الجراحة لا تنتوفر فيه أى دو اع أو دو افع معتبرة من الناحية الطبية، و وأنه

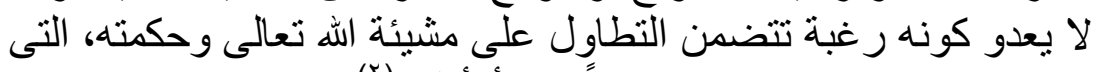
اقتضت تحديد جنس الإنسان ذكر أ كان أو أننى. (r)

(1) الجراحسة التجميلية ضوابطها والتكييف الفقهى لها، د. عبدالستار إبراهيم

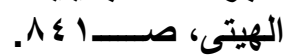

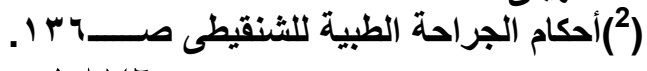




$$
\begin{aligned}
& \text { المطلب الثانى } \\
& \text { قشر الوجه، وصنفرته } \\
& \text { وسوف نتناول هذا المطلب فى فرعين: } \\
& \text { الفرع الأول: قشر الوجنه }
\end{aligned}
$$

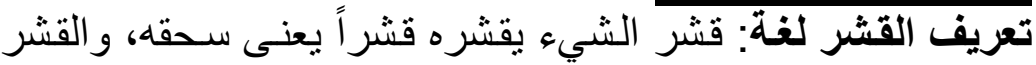

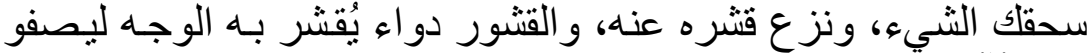

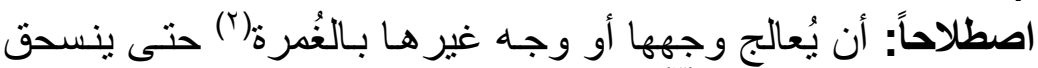

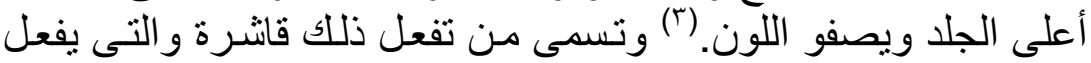

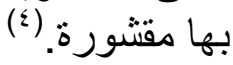

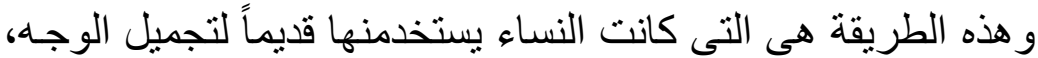

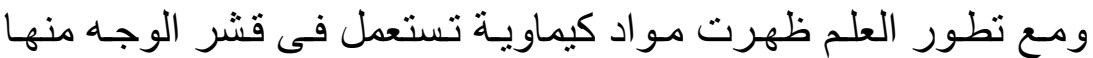

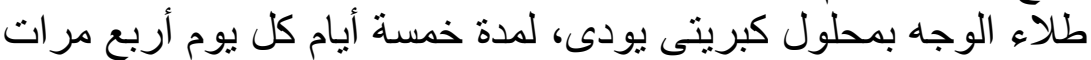

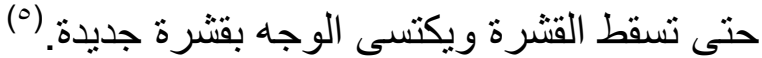

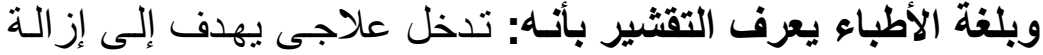

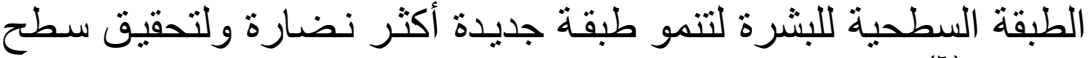

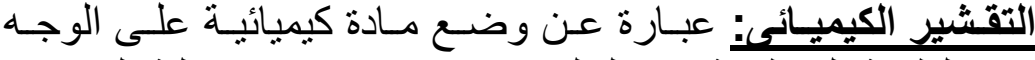

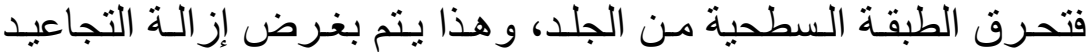

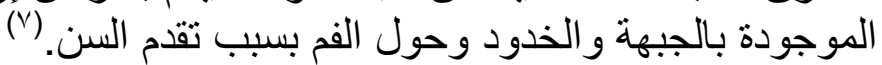

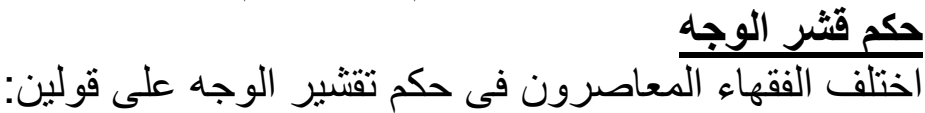

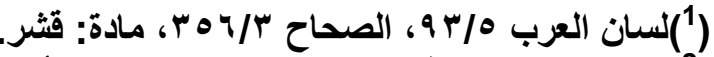

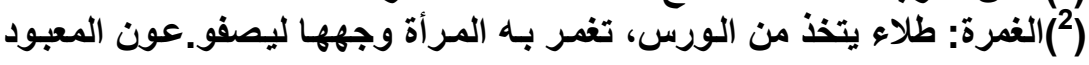
. $\mathrm{r} \leqslant 0 / 1$

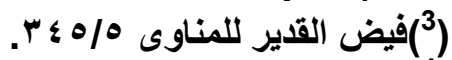

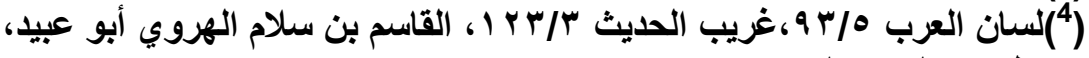

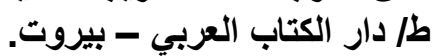

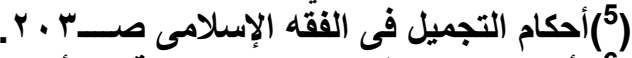

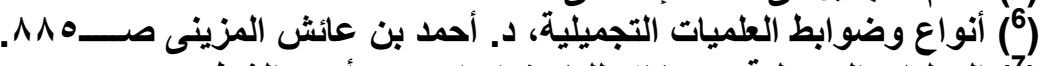

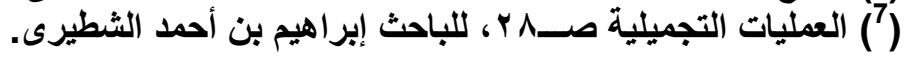




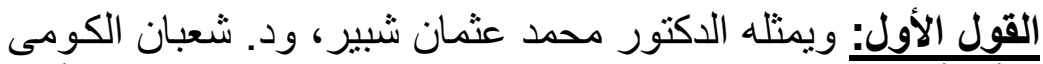
وقد رأوا أن قشر الوجه حر ام على الفاعلة و المفعول بها وذلك للأدلة

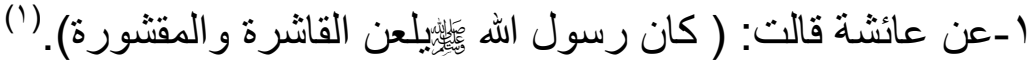

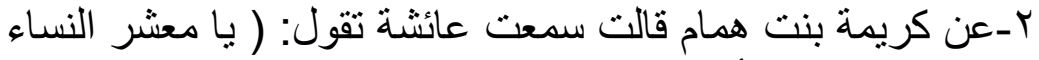
إياكن وقتشر الوجه. فيألتها

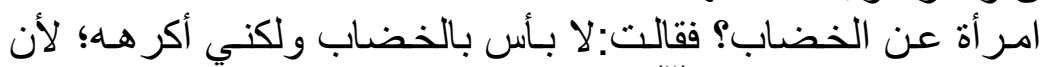

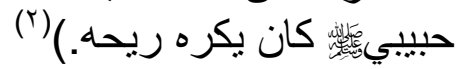
وجه الدلالة: حيث نهى في الحديثين عن قشر الوجه و النهى يقتضى

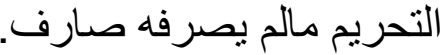

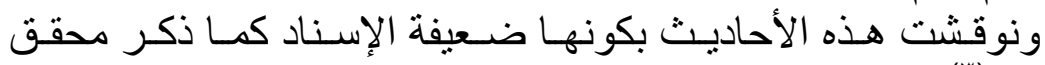

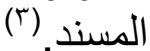

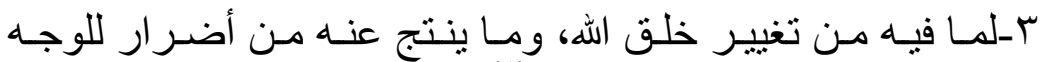

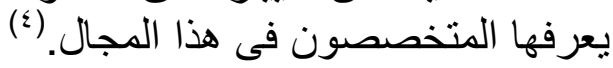
و لايدخل فى هذا ما تستعمله المر أة من مر اهم لإز الة الكُلف وتحسين

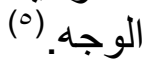

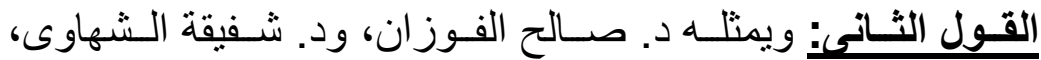

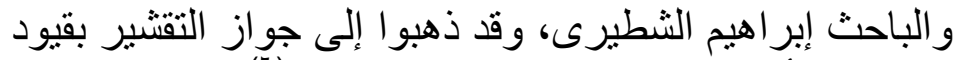

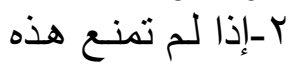

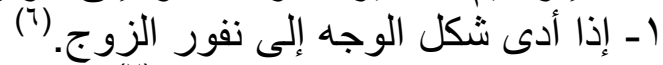

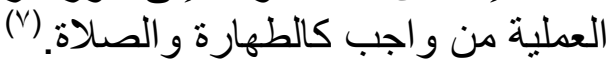
وقد استنلو العلى ذلك بالأدلة التالية:

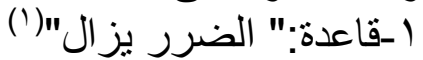

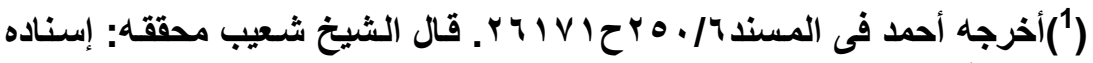

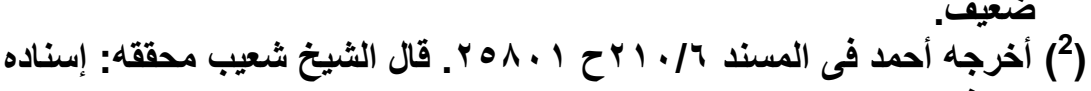
ضعيف.

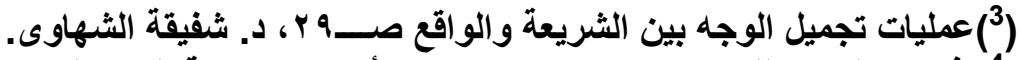

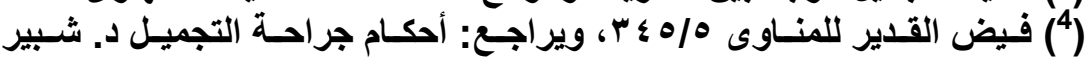
صـ

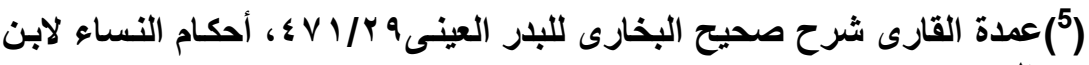

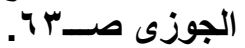

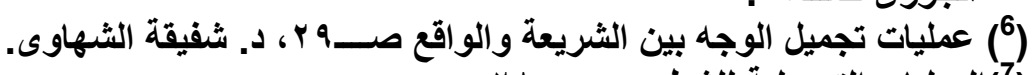

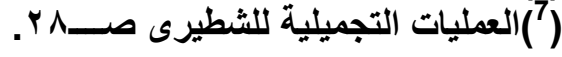
IAVA 


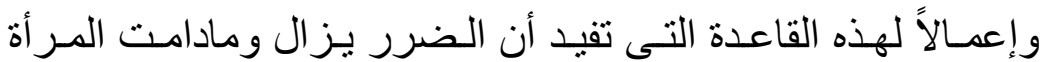

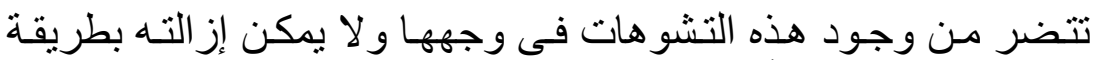

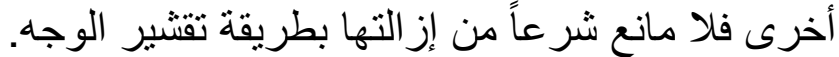

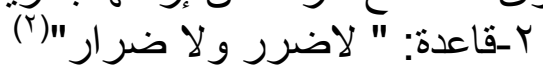

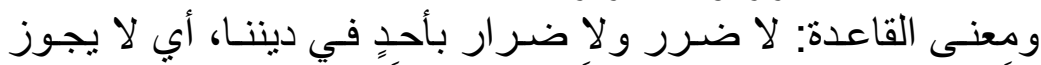

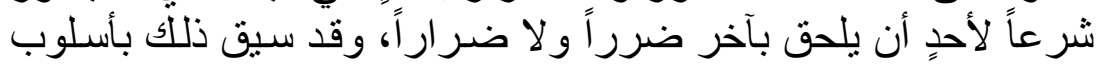

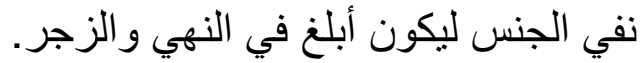

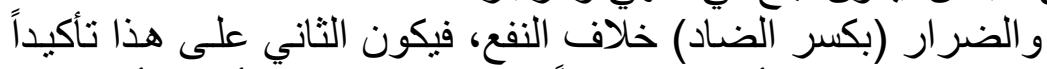

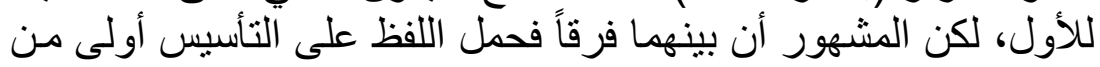

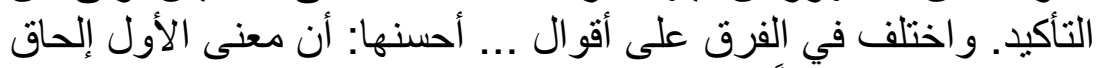

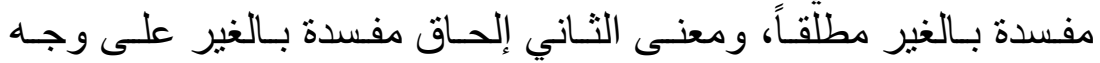

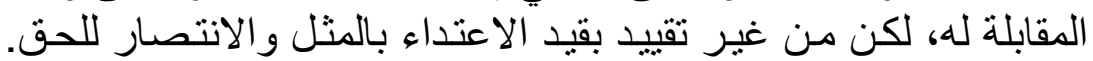

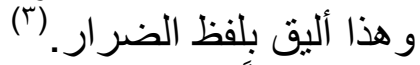

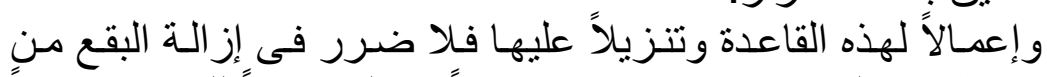

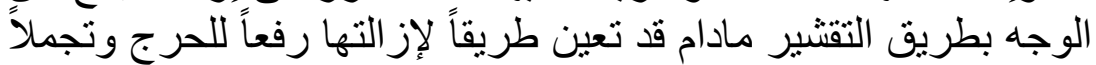

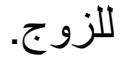
ب-حث الإسلام فى نصوص متعددة على تزين المـر أة لزوجها وهذا

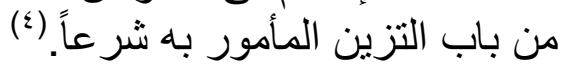

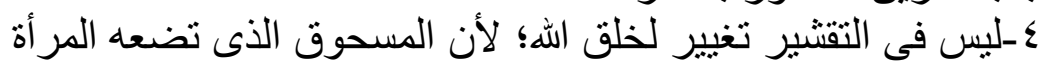

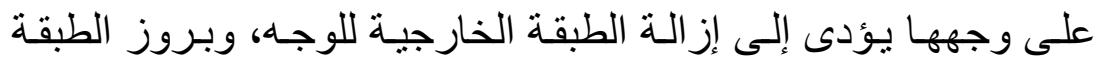

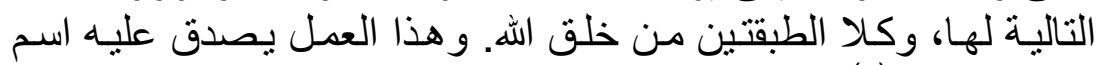
تجديد الخلايا. (0) النوال

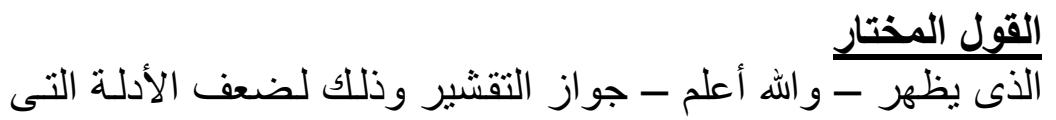

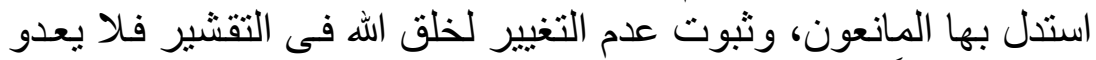

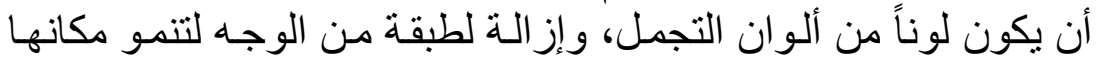

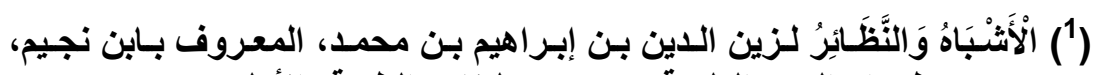

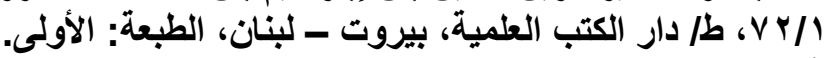

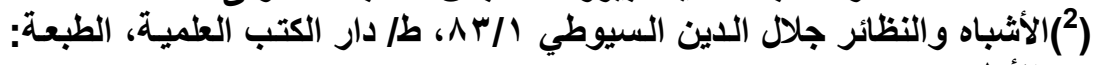

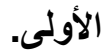

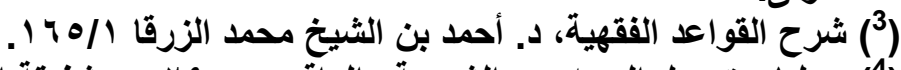

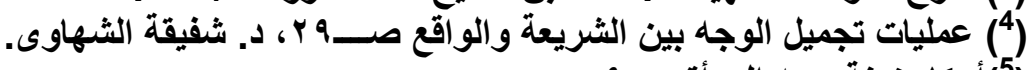

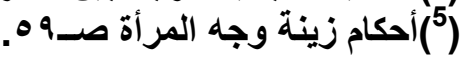


طبقة طبيعيـة أخرى، فيقاس جوازه على جواز إز الـة الكلف و النمش ونحو ها. (i)

\section{الفرع الثانح: صنفرة الوجه}

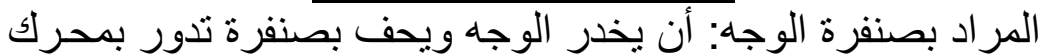

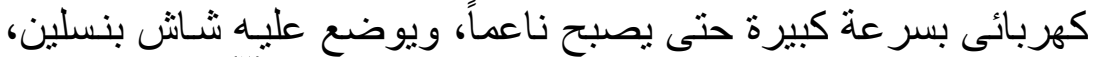

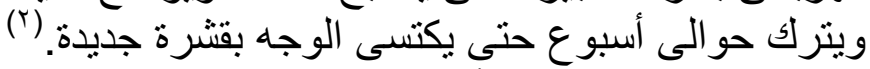

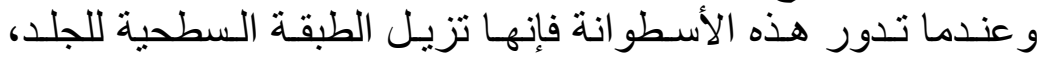

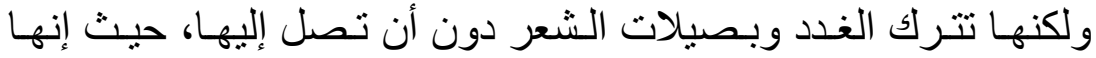

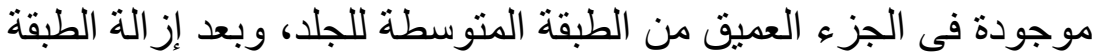
السطحية للجلد، فإن الطبقة المتوسطة تنمو لتكون طبقة سطحية جديدة

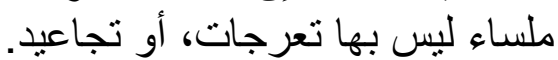

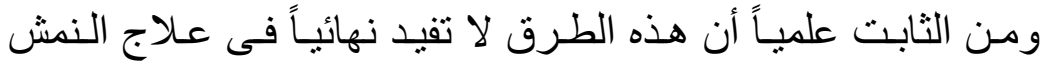

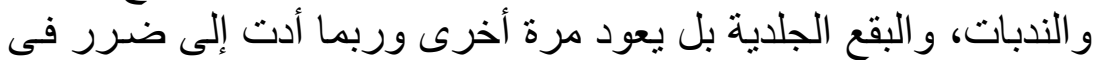

إذا ثبت صنفرة الوجه:

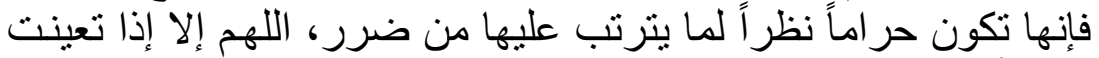

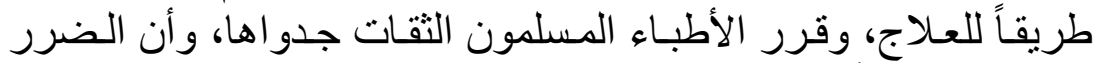

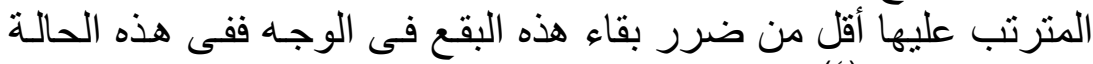

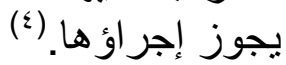

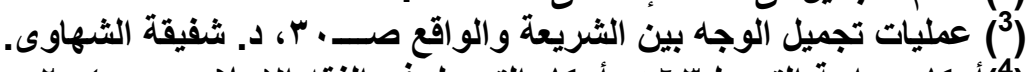

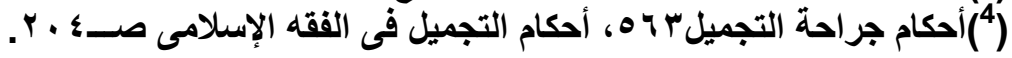
$1 \wedge \Lambda$. 


\section{المطلب الثالث \\ شفط الدهون من الجسم بالجراحة الثبات}

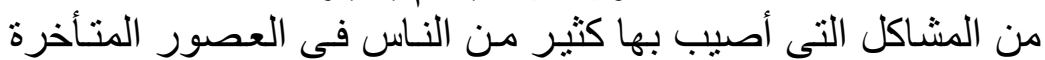

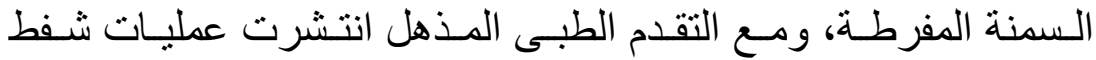

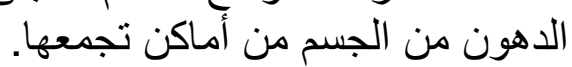

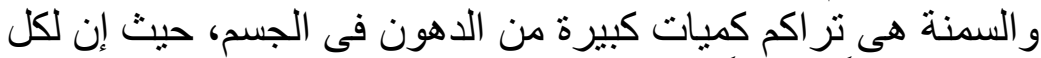

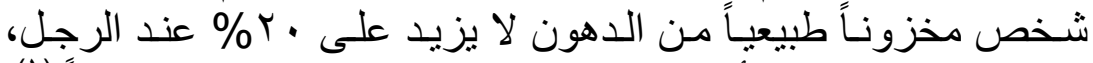

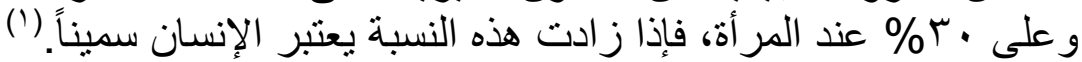

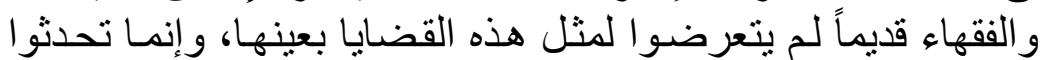

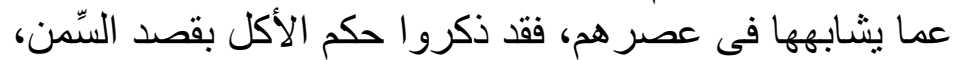

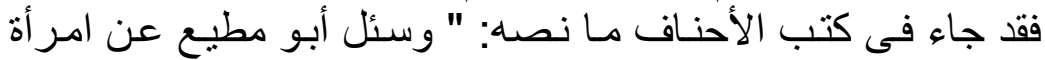

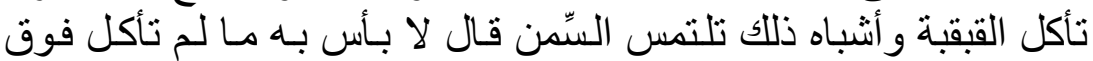

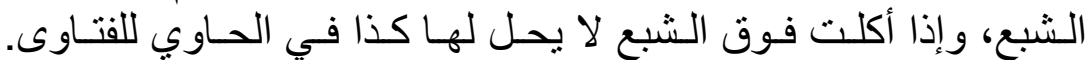

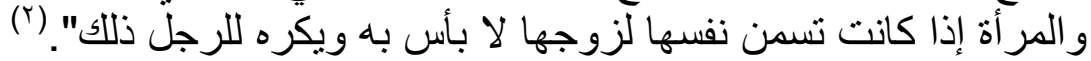

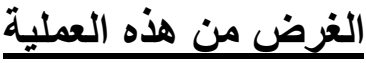

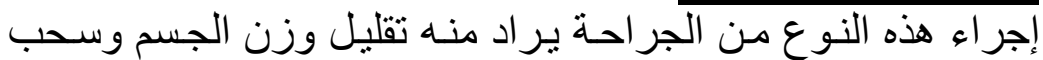

الدهون منه، لكن ذللك يختلف باختلاف السبب و الداعى، ولاعن الذلك حالتان:

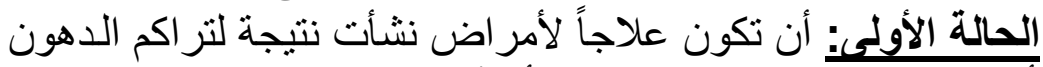

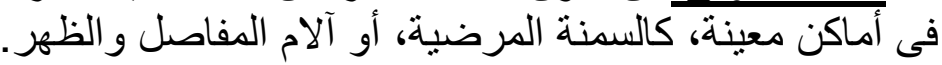

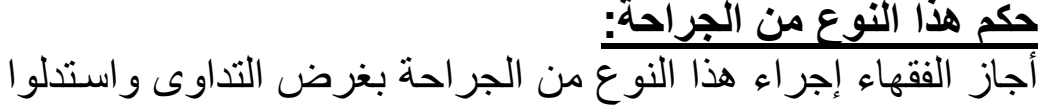
على ذلك بــــاز 1 -إن هذا من قبيل العلاج المشروع و الذى جاءت النصوص العديدة

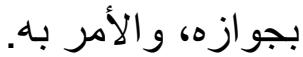

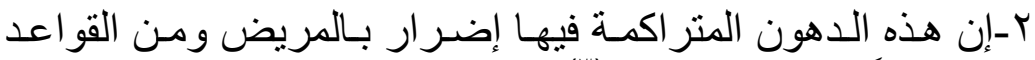

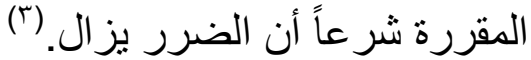
لكن معالجة السمنة بهذه الطريقة يشترط فيها ما ليلى:

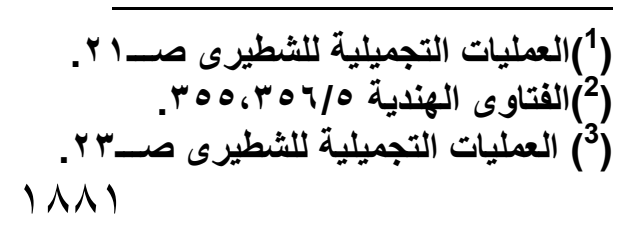




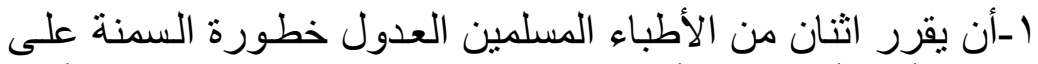

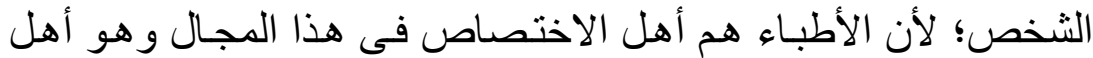

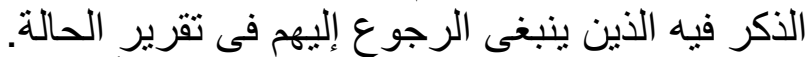

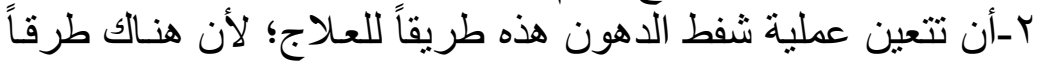

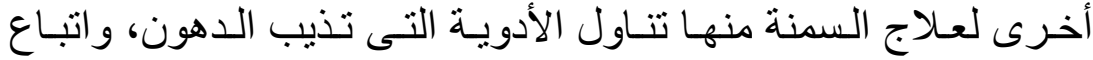
بر امج معينة فى التغذية، وممارسة الرئة الرياضة.

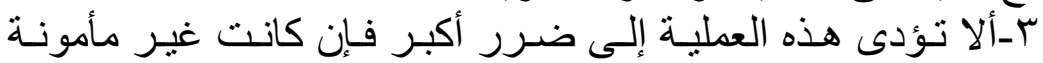

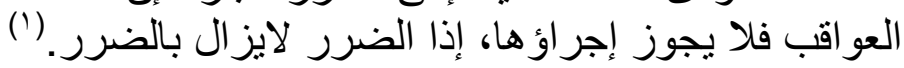

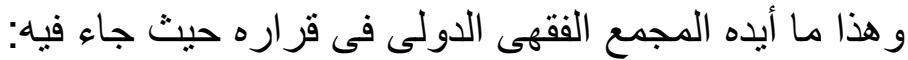

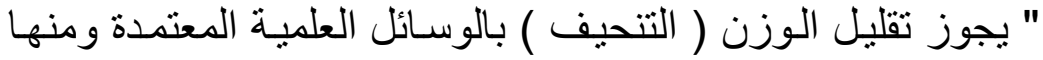

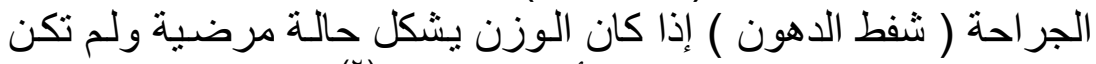

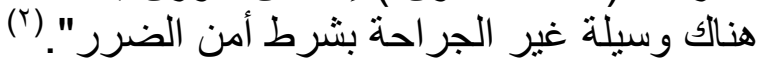

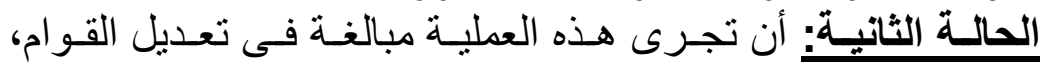
وتحسين الدظهر العام للجسم، فقد اختلف الفقهاء المعاصرون في فلى ذلك الكي

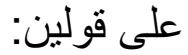

$$
\text { القول الأول: جواز إجراء هذه الجراحة بشرطين: }
$$

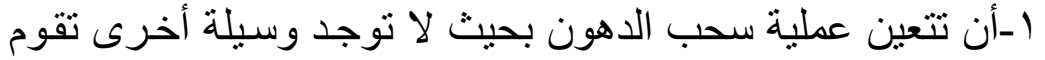

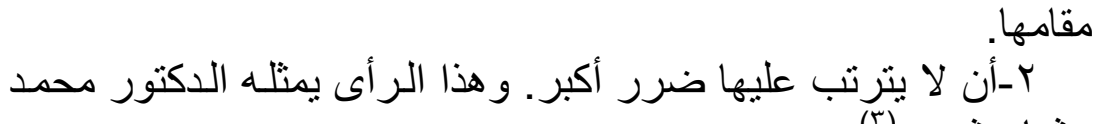

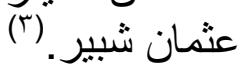

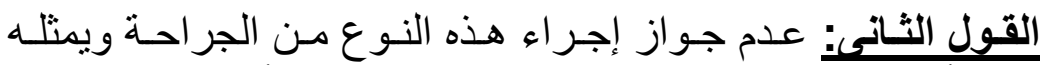

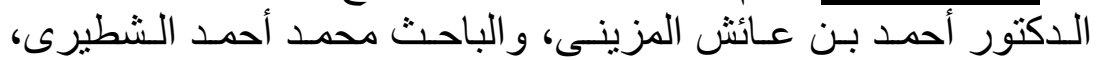
وظاهر قرار المجمع الفقهى الدولى.

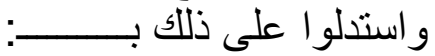

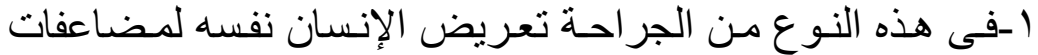

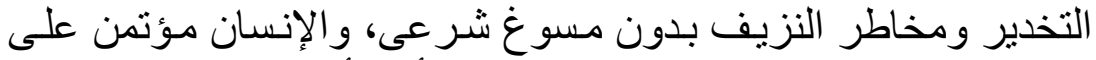
نفسه وبدنه فلا يجوز لله تعريضها للمخاطر أو الأذى.

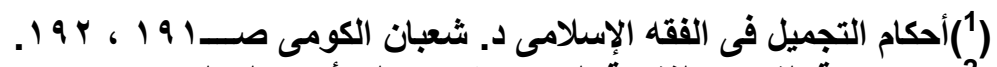

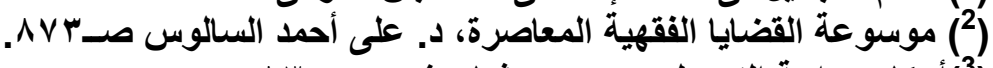

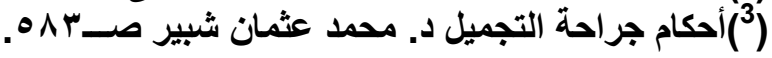
l ANY 


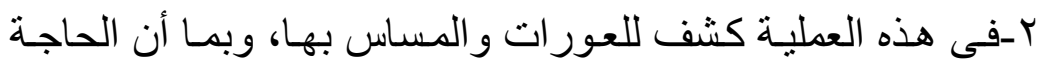

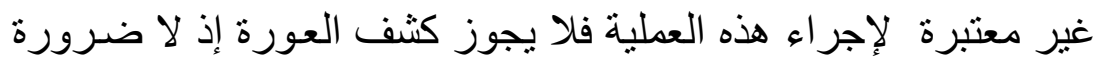
تدعو إلبها. (1)

\section{المطلب الرابع: تجميل الحروق بترقيع الجلد}

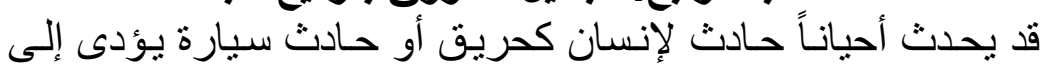

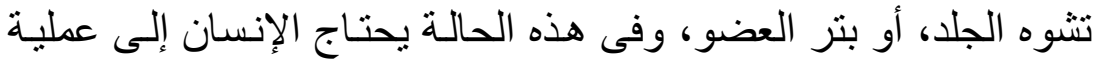

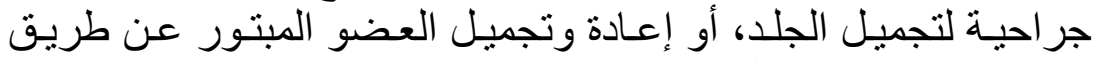

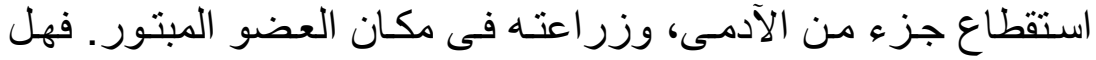

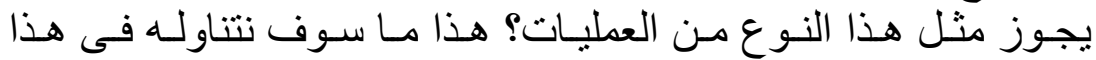

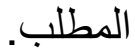

تعريف هذا النوع من الجر احة:

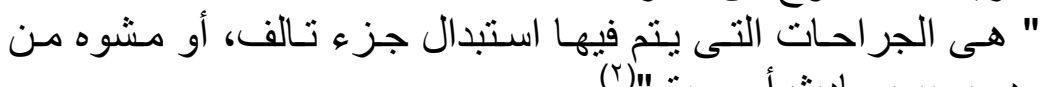

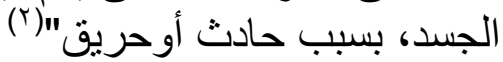

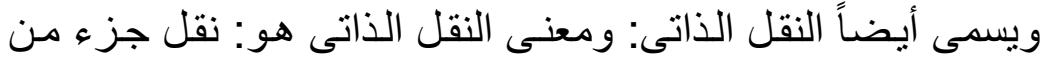

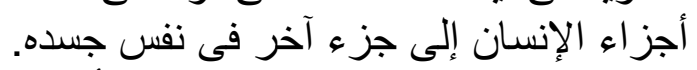

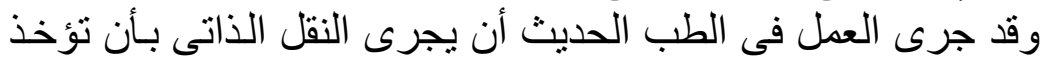

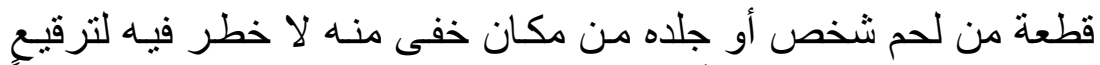

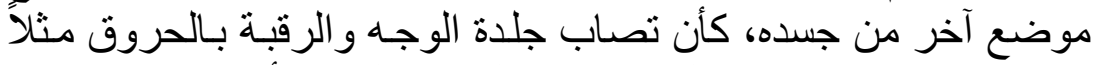

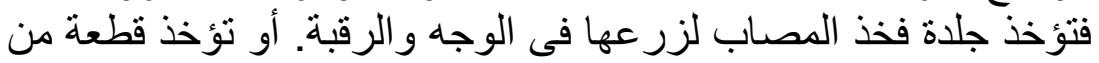

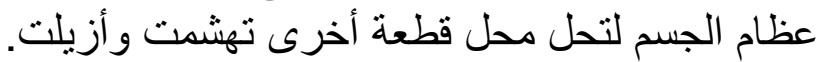

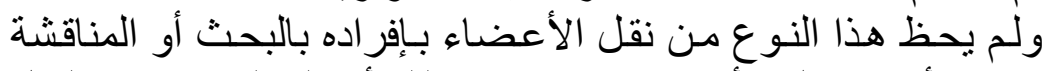

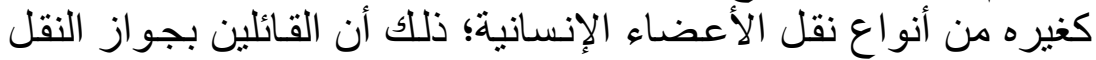

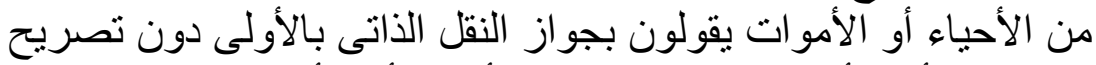

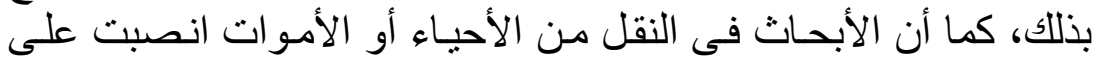

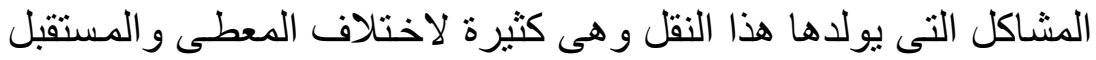
وحالة كل منهما وخصوصية العضو المنقول، بينما هى فى النقل النقال الذاتى قليلة جداً.

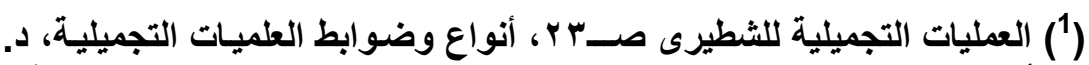

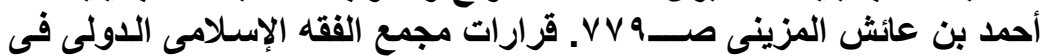

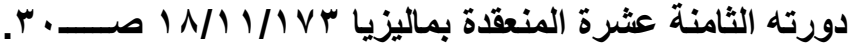

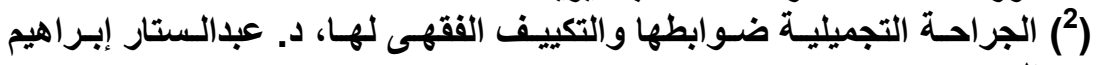

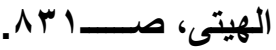


و لا تخلو الحاجـة الداعية إلى النقل و الزرع فى هذا الضرب مـن

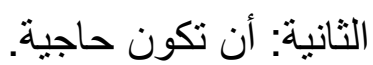

الأولى: أن تكون ضرورية.

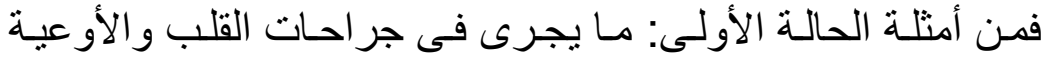

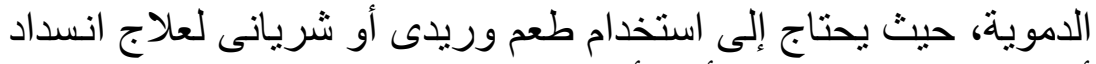

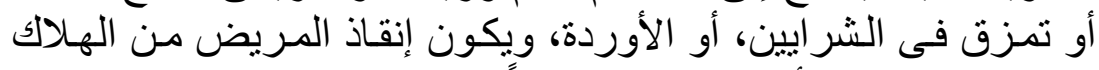

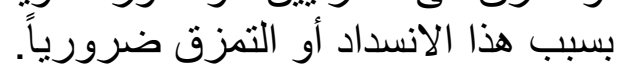

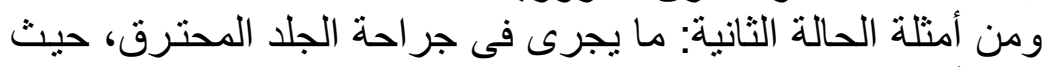

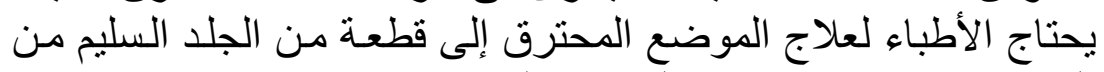

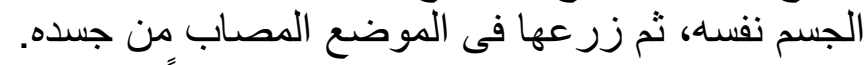

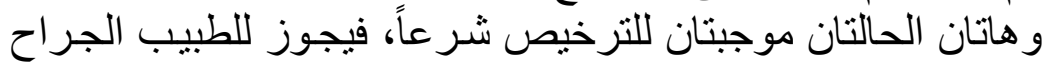

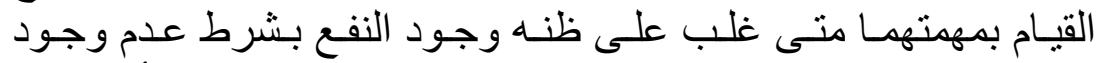

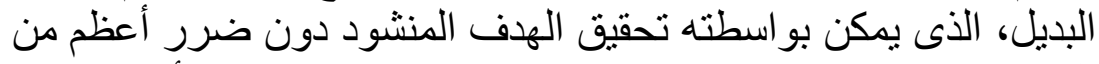

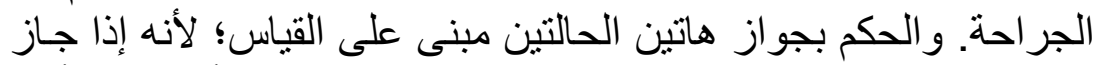

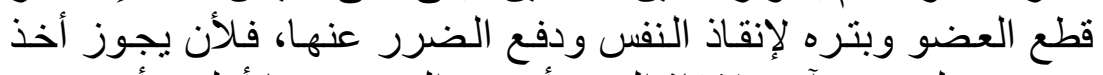

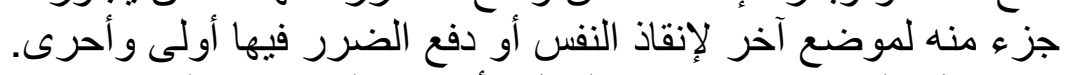

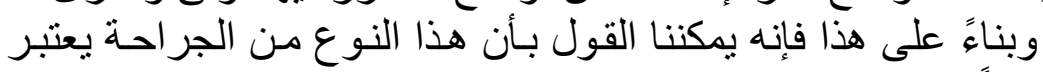

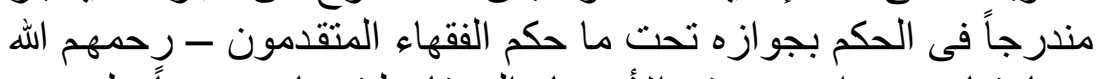

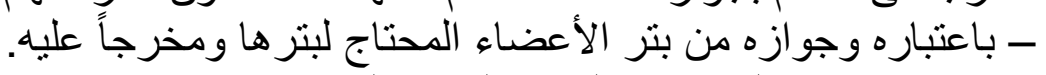

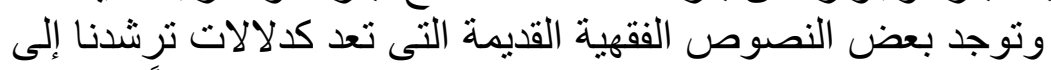

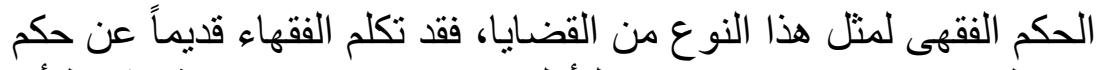

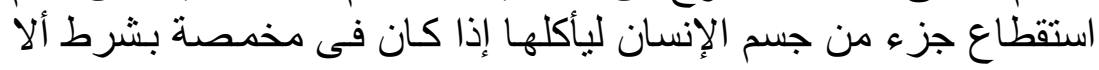
يجد غير ها،

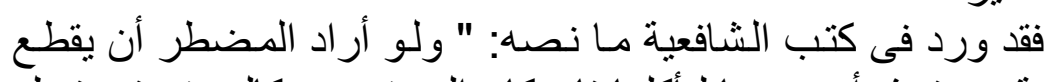

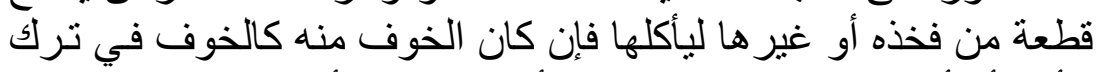

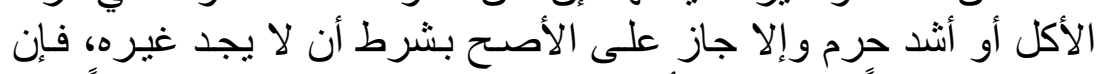

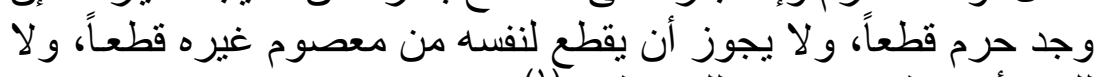

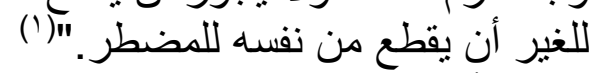

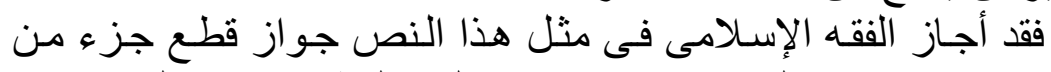

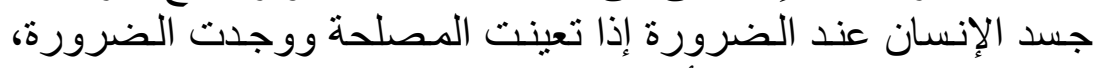

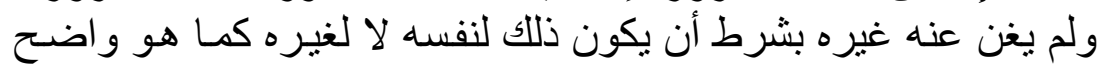

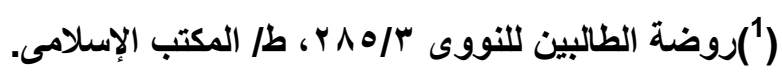
INA 


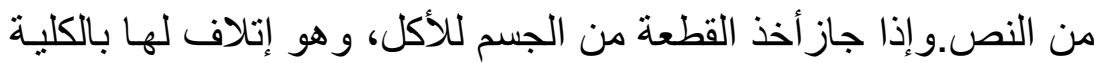

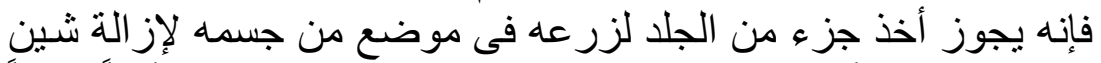

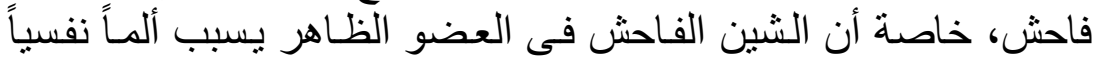
كبير للإنسان. (') فاهن

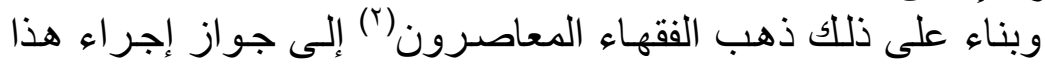

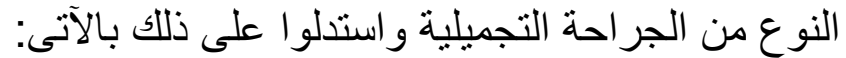

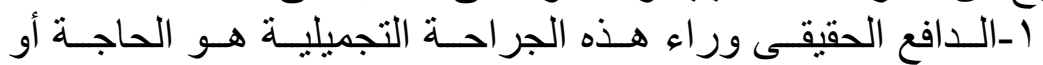

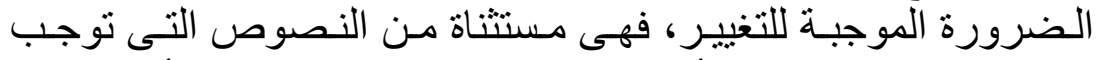

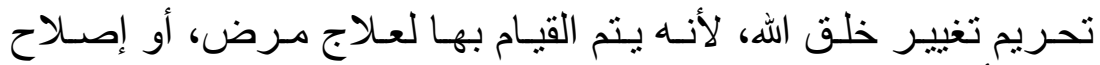

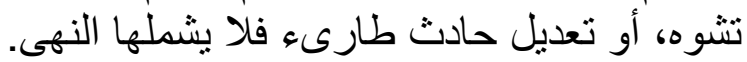

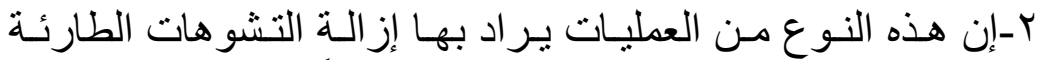

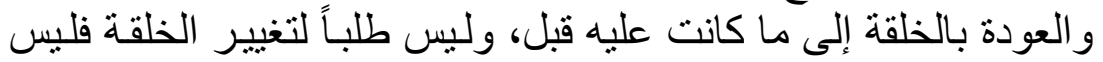

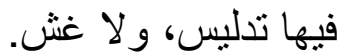

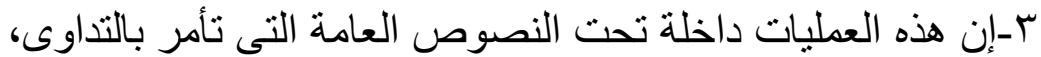

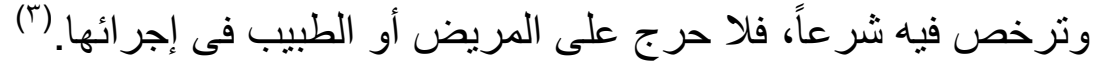

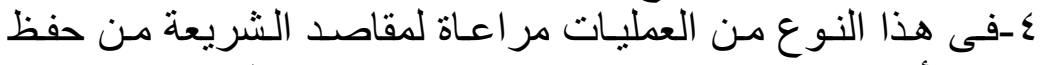

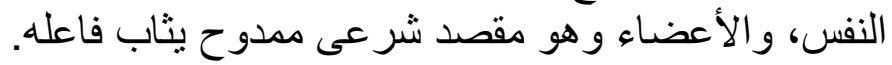

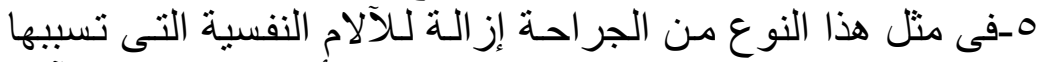

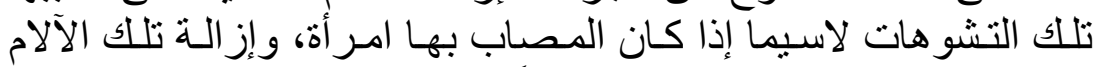
النفسية عن المريضلا حرج فيه شر عاً ليعود لممارسة حياته الطبان الطبيبعة.

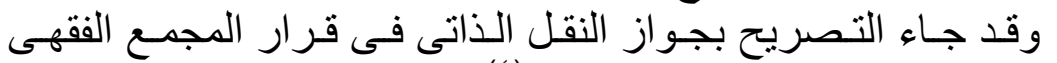

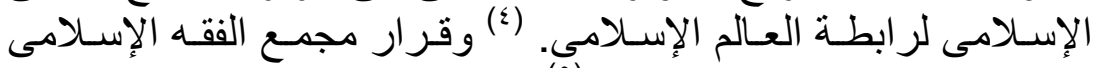

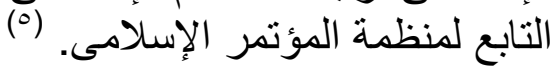

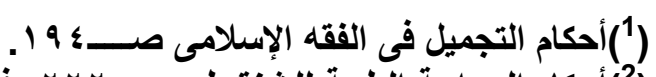

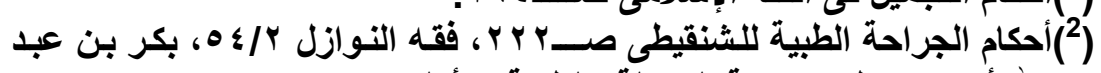

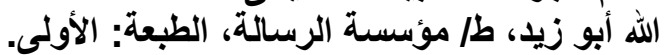

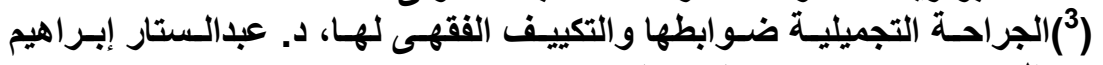

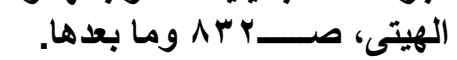
(4) قرارات المجــع الفقهى التـابع لرابطة العـالم الإسـلامى الداورة الثامنـة عـام

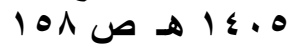

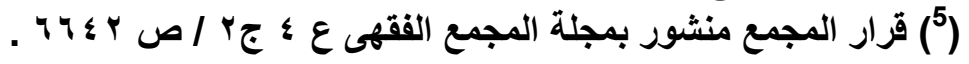
$1 \wedge \wedge 0$ 


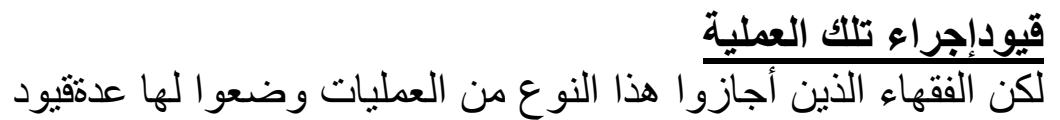

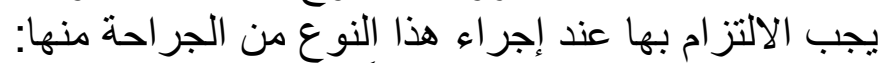

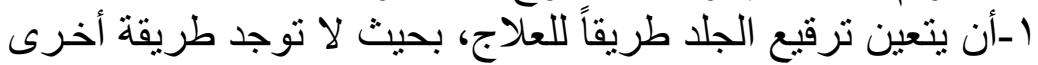
تقوم مقامه. بـأن يكون الضرر المترتب على عدم الترقيع بقصد التجميل أعظم

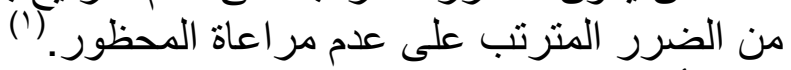

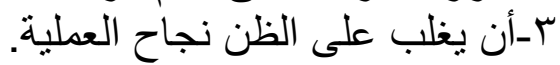

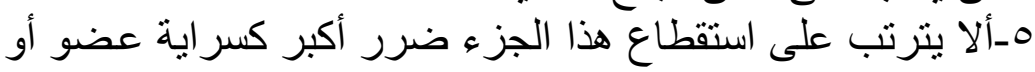
تلفه.

7-أن يؤخذ إذن المريض، أو وليه فى غير الحالات الطارئة. (؟)

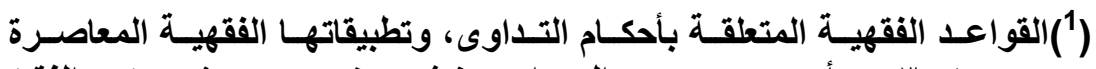

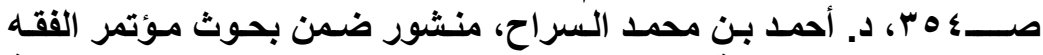

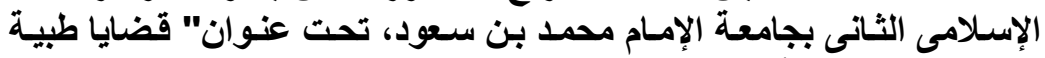
معاصرة".المجلد الأول. الجائل

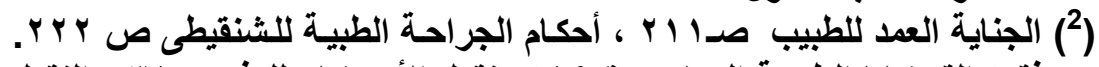

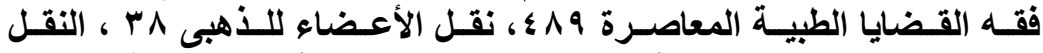

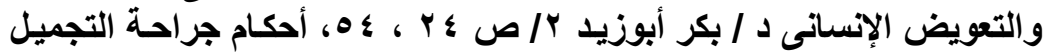

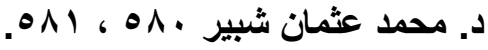
$1 \wedge \wedge 7$ 


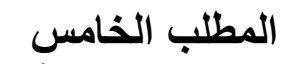 \\ عمليات تجميل الأنف}

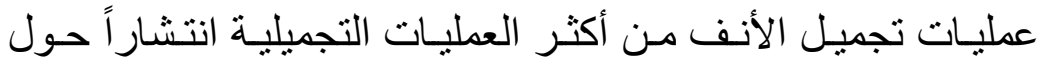

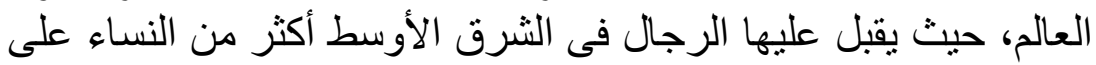
العكس فى أوروبا.

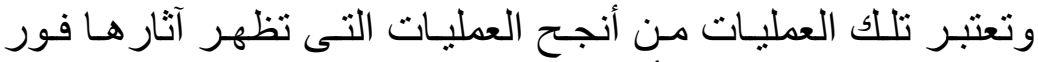
الانتهاء منها، ولعل هذا من أسباب الإقبال علئ العيها.

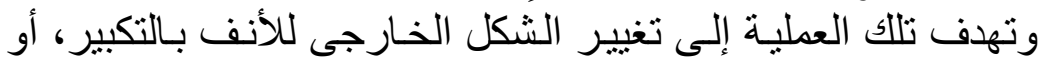

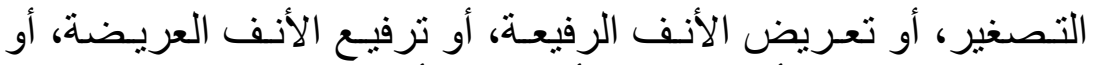

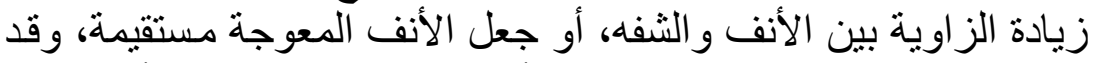

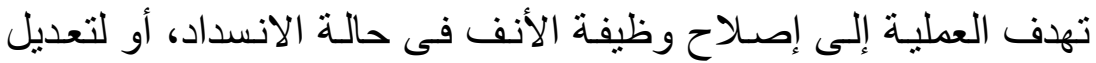

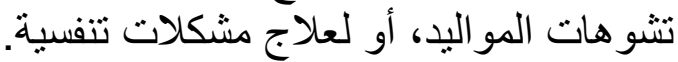

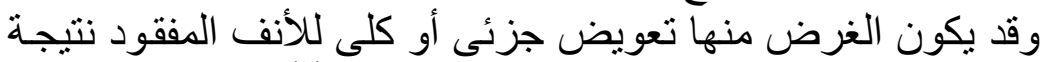

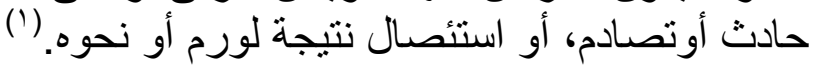

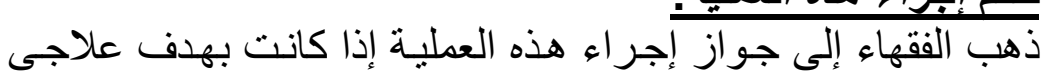

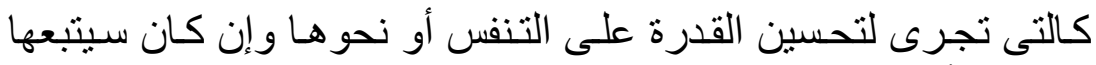

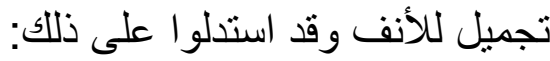

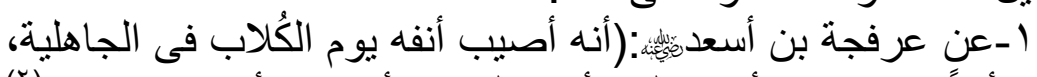

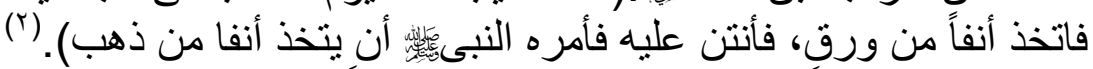

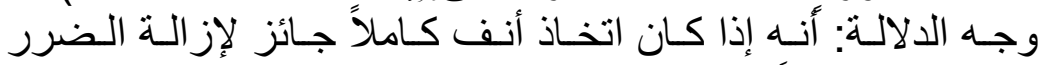

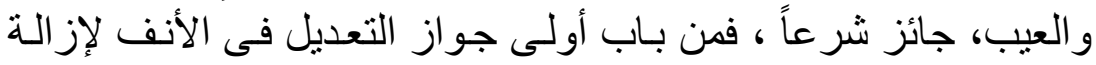

Y_النصوص الدالة على جواز التداوى و المرخصة فيه شر عاً.

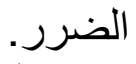
ץ-إن الغرض من هذا العملية هو إعادة الثخص الثص إلى خلى القته المعهودة

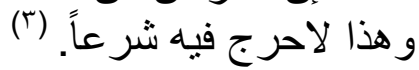

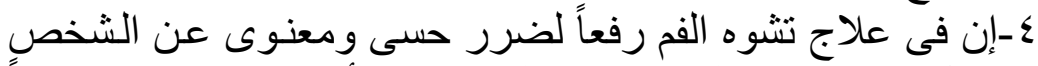

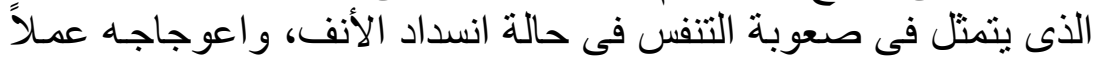

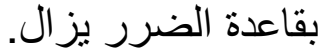

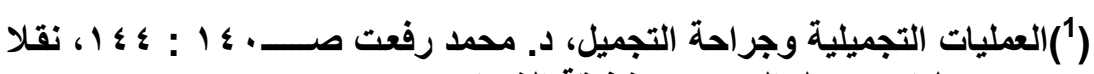

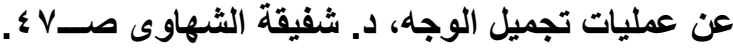

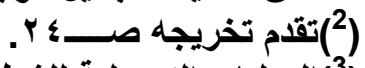
IANV 


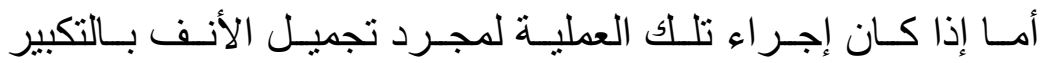

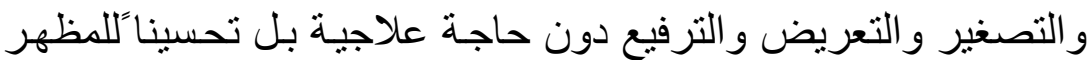

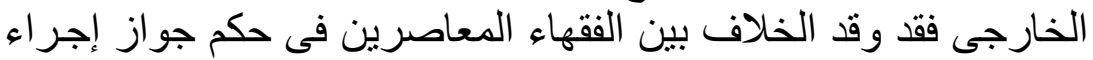
هذا النوع من الجر احة على قولين: القول الأول: حرمة إجر اء هذا النوع من الجر الجن احة وهو ما ما ذهب إليه

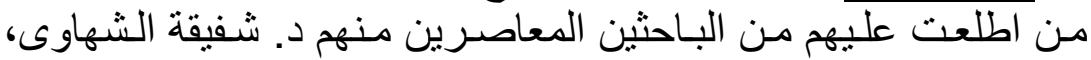

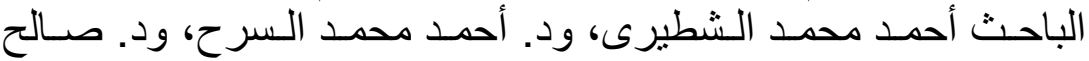

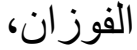

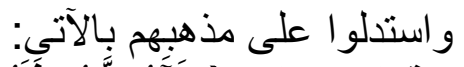

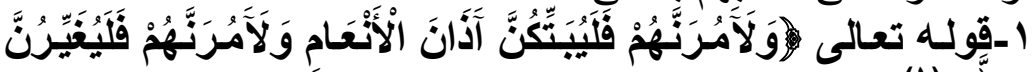

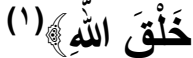
وجه الدلالة: إن فى إجراء عملية تجميل الأنف بدون دواعى علاجية

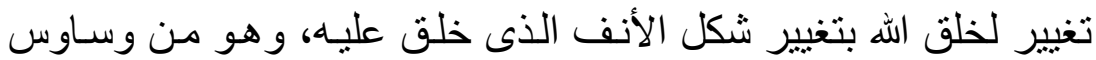

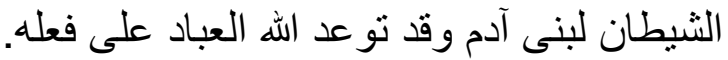

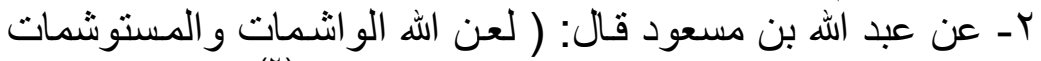

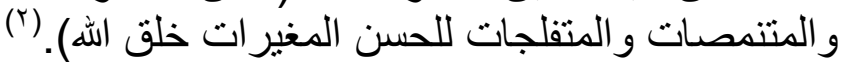

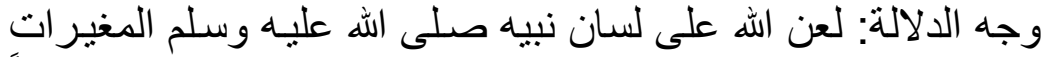
خلق الله، وتجميل الأنف بالجر احة من باب تغيير خلق الله فيكون داخلاً

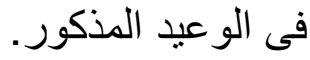
بَ-إن في مثل هذا النوع من العمليات تعريض الجسم للآلام بدون

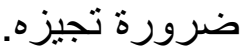
ــ-إن فيه استعمالاً للمخدر المحرم شر عاً بدون ترخيص أو حاجة أو ضرورة تبيح ذلك. هـإن فيه إسر افاً وتبذيراً حيث تبلغ تكاليف هذه العمليات الكثير من

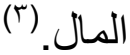
ك-إن فيها عبثاً بالخلقة التى أرداهـا الله وخلقها، وفيها عدم الرضـا بقسمة الله تعالى الذى خلق فسوى.

$$
\begin{aligned}
& \text { (1) سورة النساء آية (199) (119). }
\end{aligned}
$$

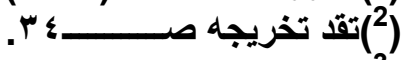

$$
\begin{aligned}
& \text { (3) عمليات تجميل الوجه للثهاوى صـــ } \\
& \text { I } \wedge \wedge 1
\end{aligned}
$$




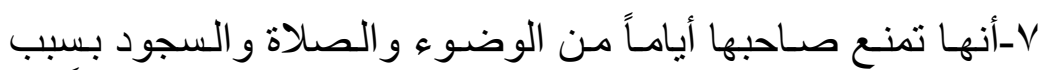

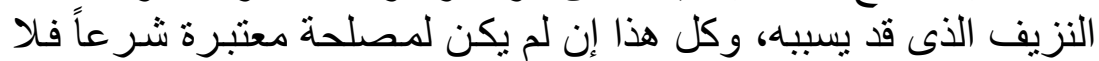

القول الثانع:جواز إجر اء جر احة تجميل الأنف بدون دواءواعى طبيـة وهو ما ذهبت إليه اللجنة الدائمة للإفتاء بالمملكة العربية السعودية.

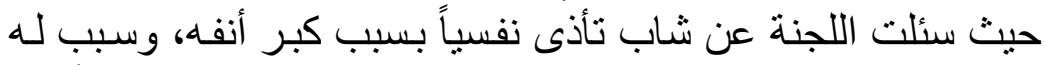

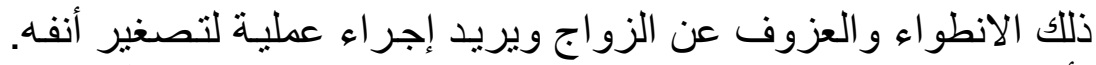

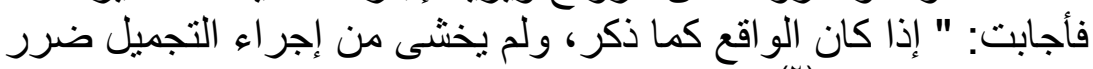

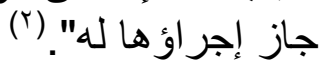

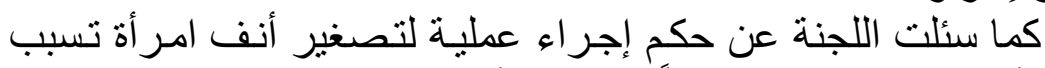

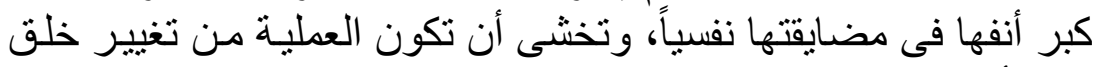

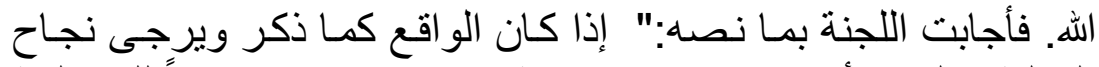

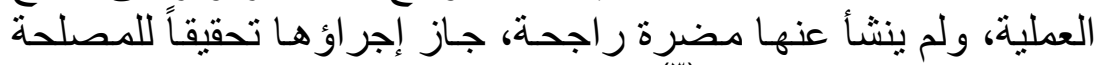

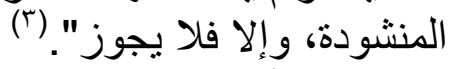

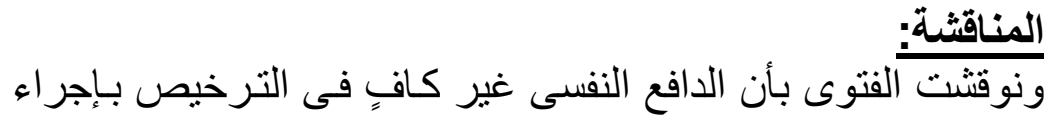

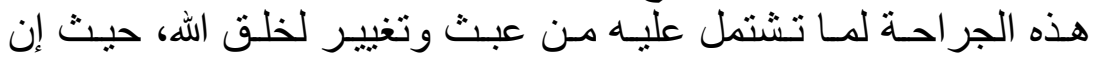

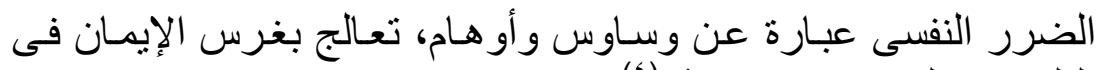

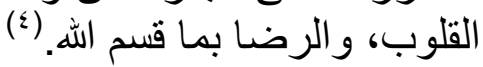

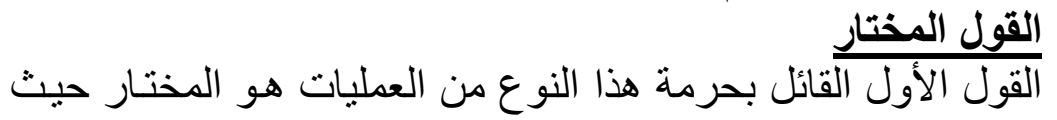

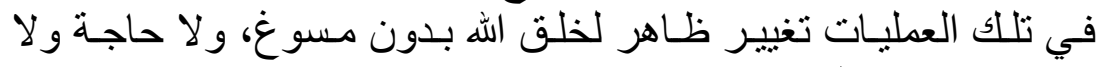
ضرورة. وبالله التوفيق.

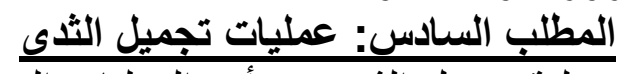

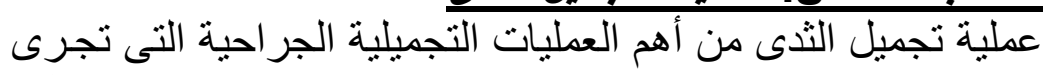

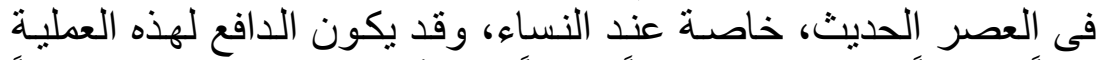

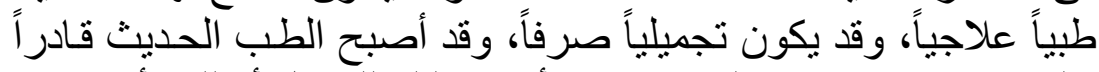

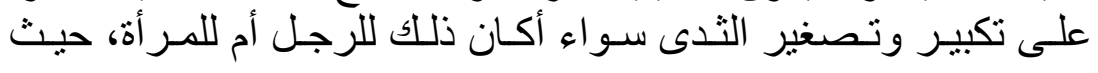

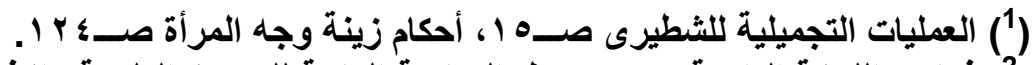

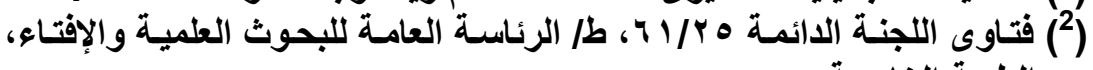
الطبعة الخامسة.

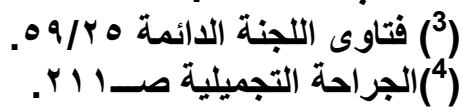


تطورت هذه الجراحة تطوراً مذهلاً تمكن الأطباء من خلاله إلى إمكانية

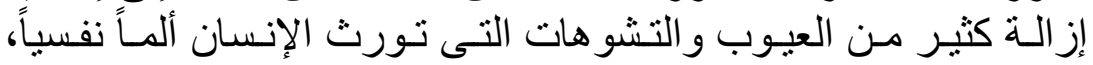

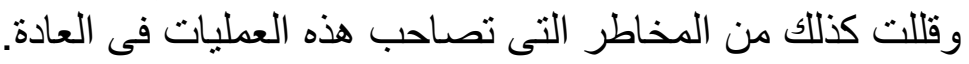

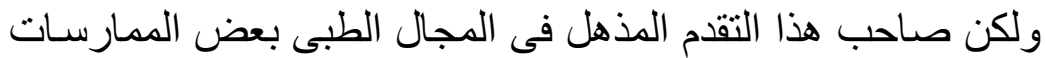

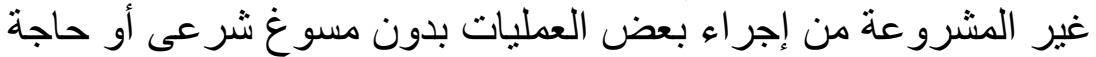

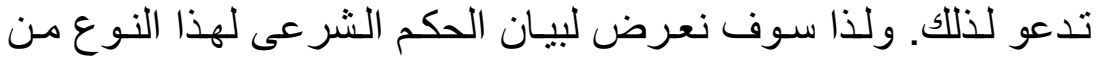

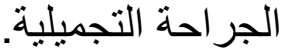

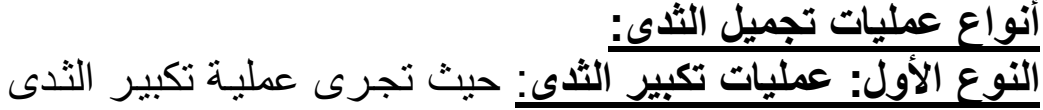

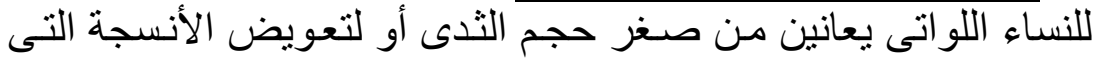

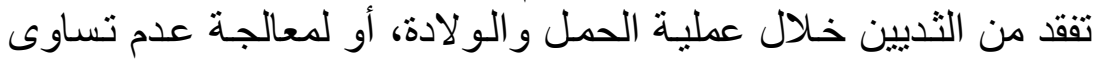

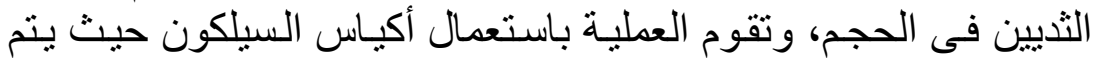

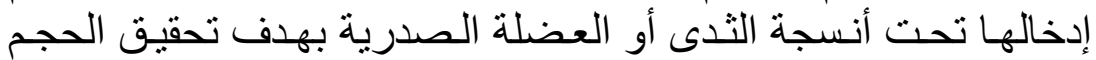

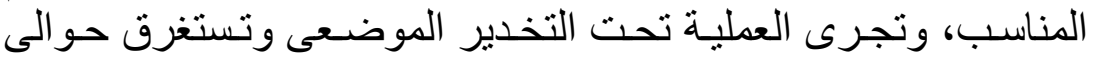
نصف ساعة.

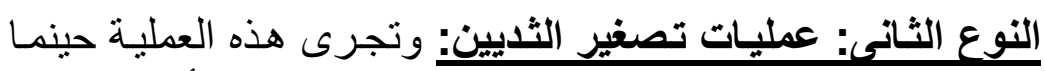

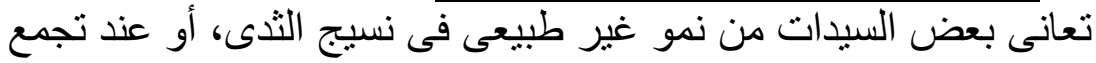

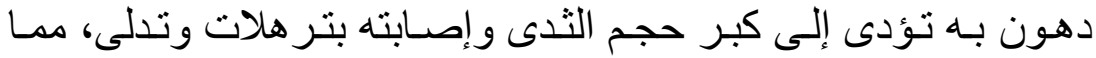

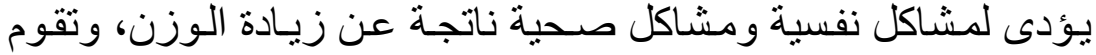

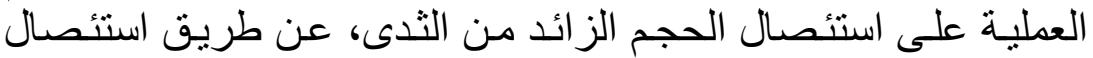

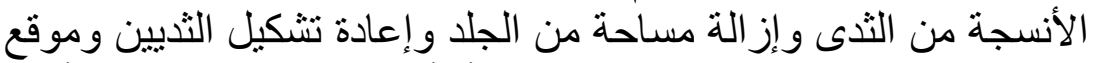

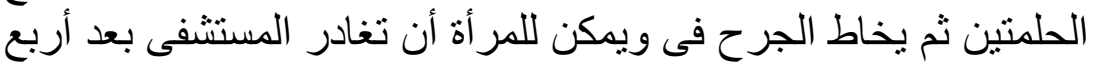

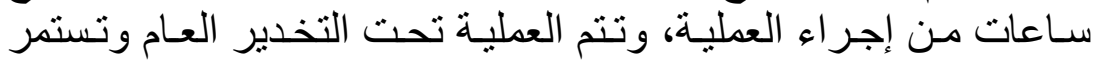

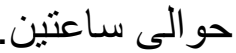
النوع الثالث: عمليات رفع الثيدين: وتجرى العملية عندما يفقد جسم

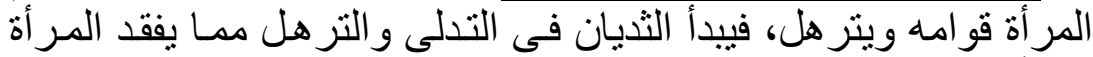

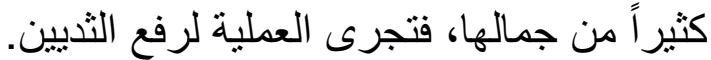

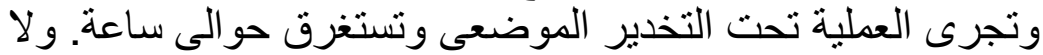

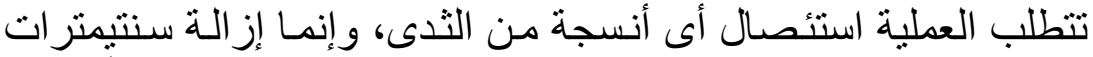
محدودة من الجلد ولذلك يبدو الثدى بنفس الحجم لكنه أكثر تماسكاً.

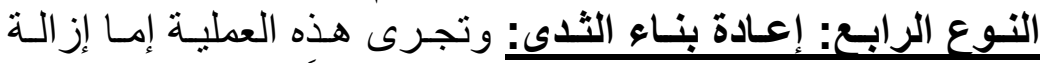

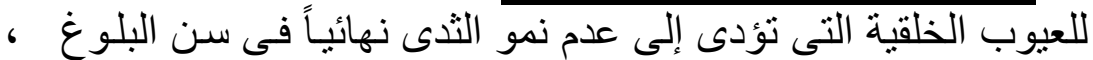

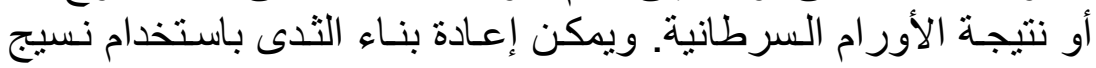




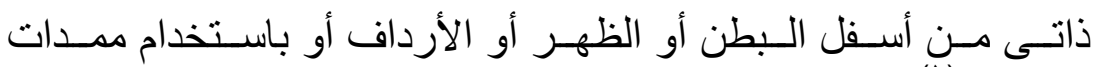
صناعية. (') داتهن حكم إجراء جراحة تجميل الثذى فقهاً

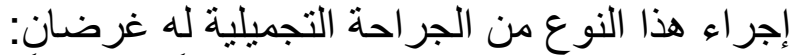

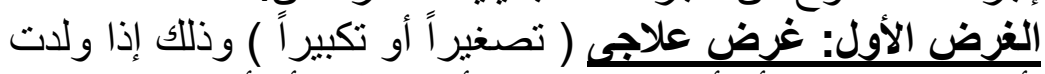

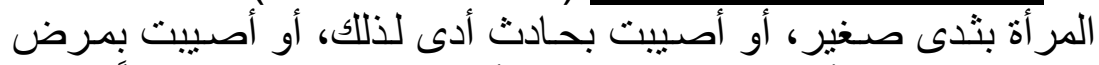

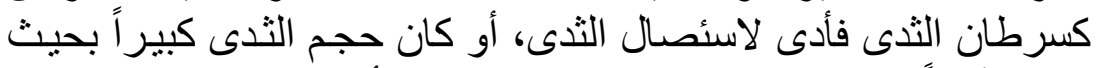

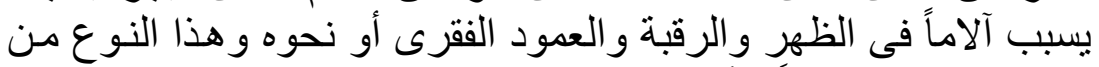
الجر احة جائز شر عاً للأدلة التالية:

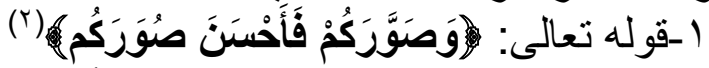

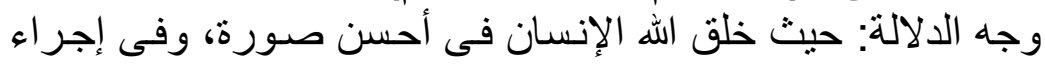
هذه العملية إعادة لهذه الصورة الحسنة التى خلق الله الناس عليها.

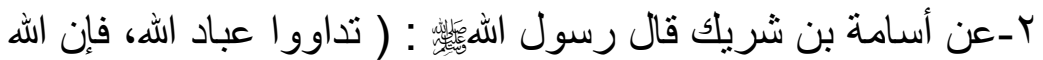

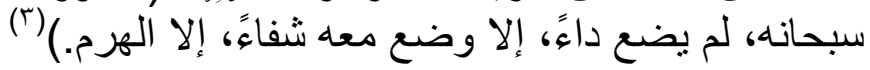

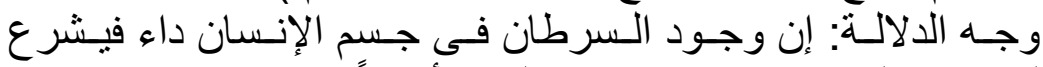

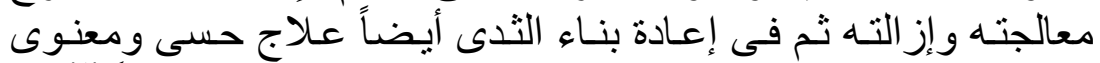

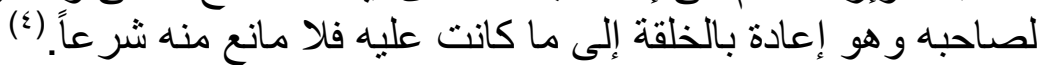

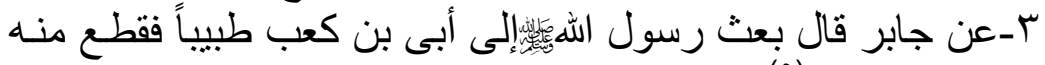

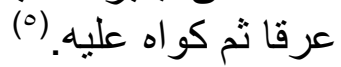

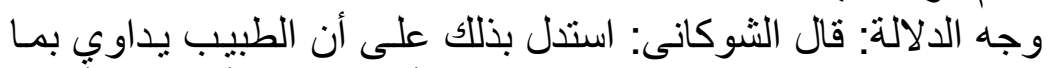

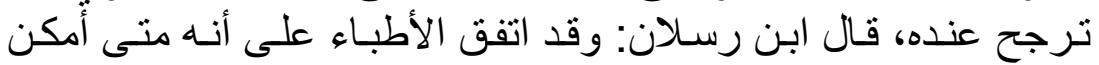

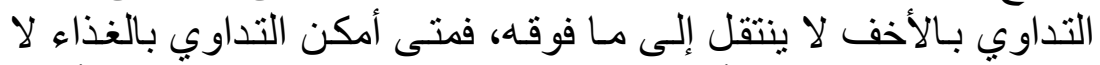

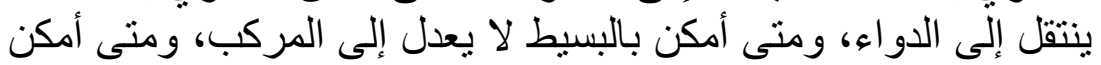

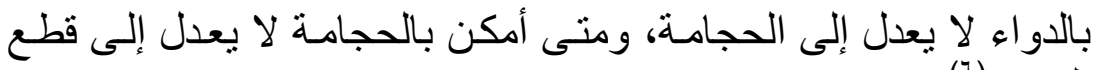

العرق. (؟) العاء

(1)(العمليات التجميلية للباحث إبراهيم أحمد محمد الثطيرى صـــآب وما بعدها.

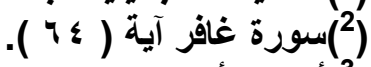

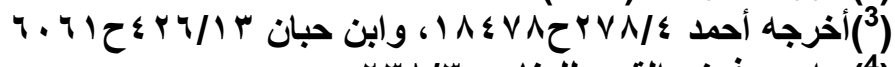

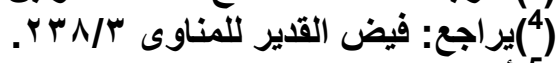

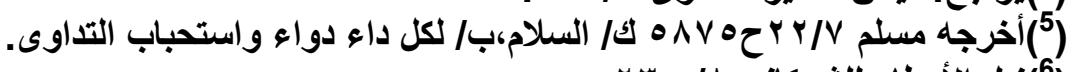

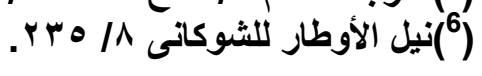




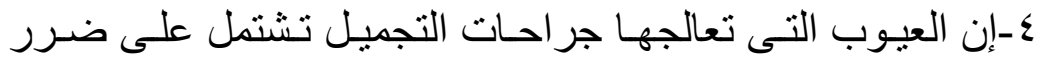

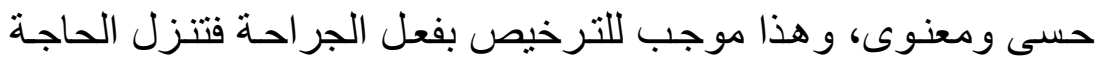

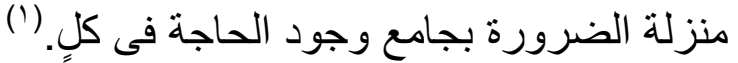

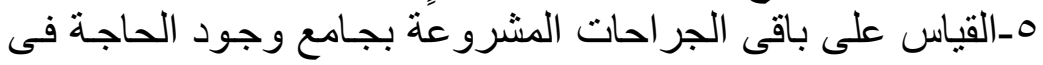

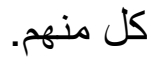

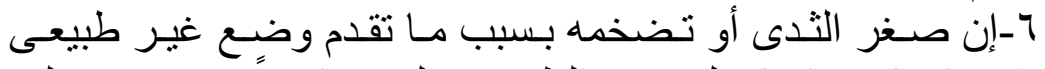

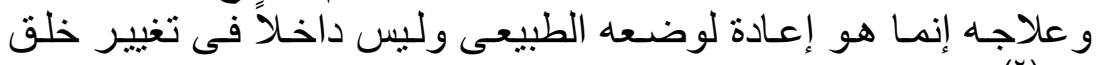

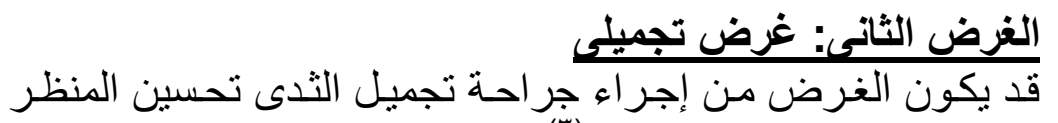

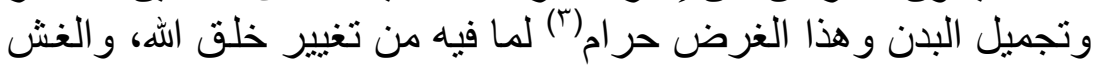
و التدليس وقد استند الفقهاء فى تحريمه على على الأدلة التالية:

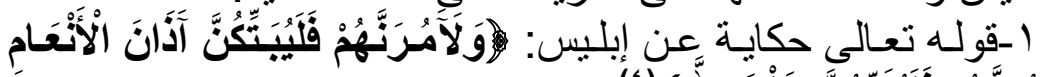

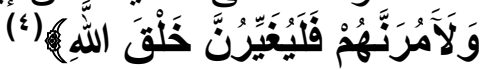

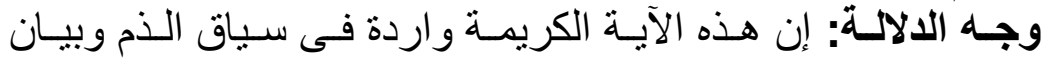

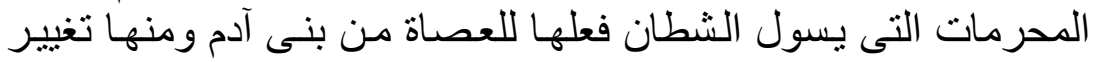

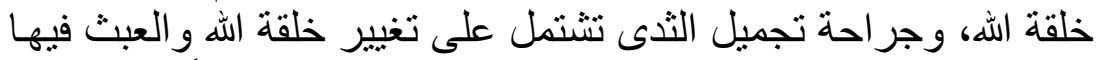

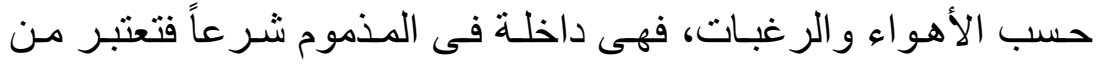

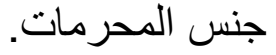
ك- عن عبد الله بن مسعود قال: ( لعن الله الو اشمات و المستوشمات

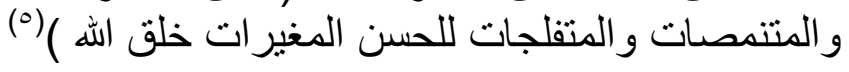

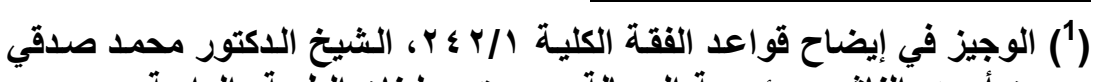

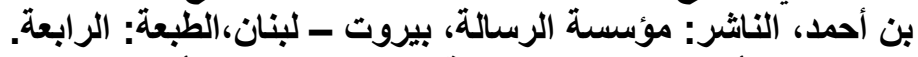

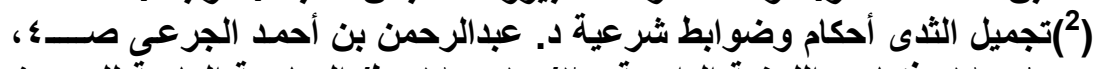

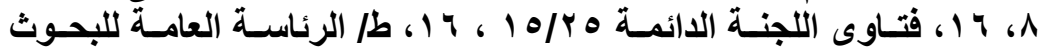
العزمية والإفتاء، الطبعة الخامسة.

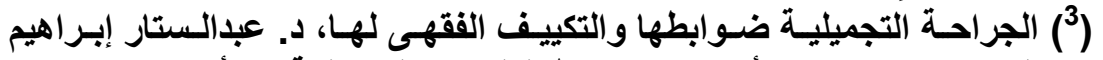

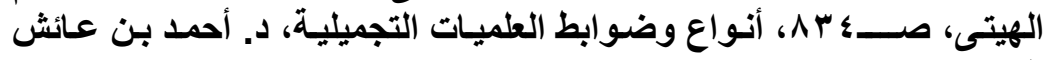

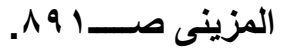

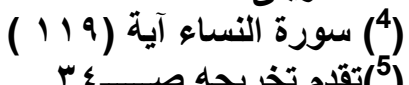




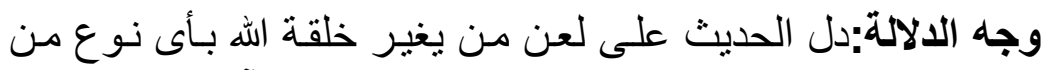

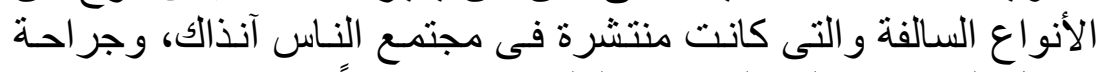

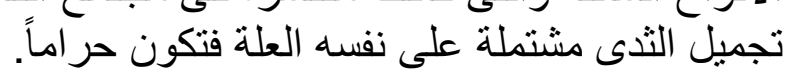

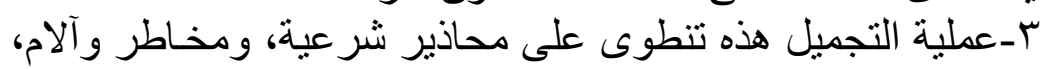

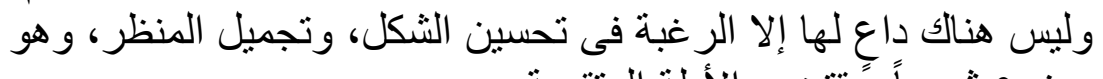

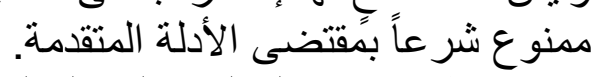

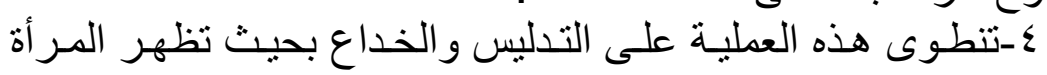

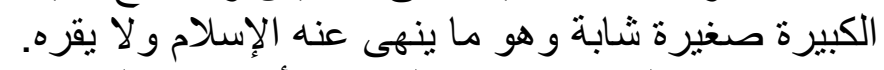

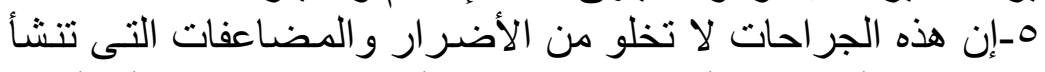

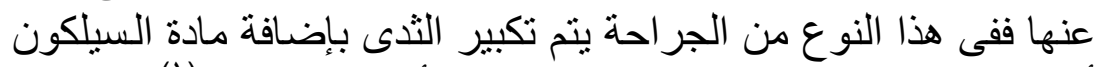

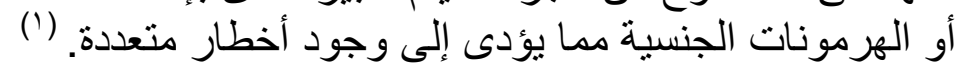

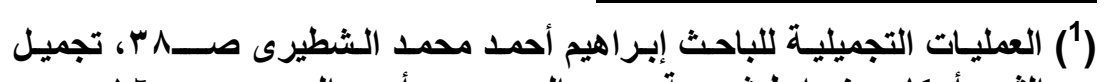

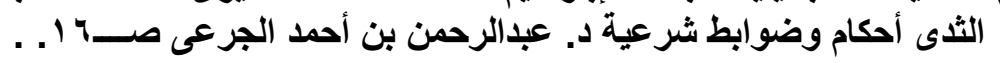
1194 


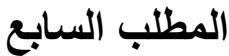

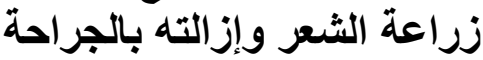

الثعر من أهم أجزاء البدن التى يتجمل بها الإنسان، وقد كانه التهان للنبى

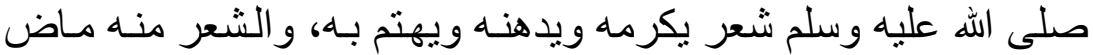

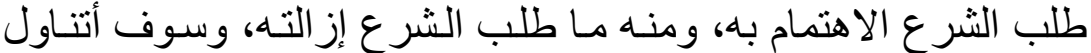

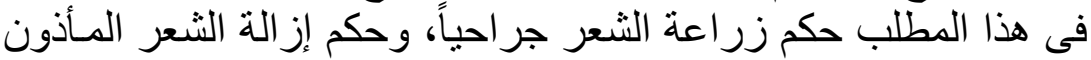
فى إز الته عن طريق الجر احة لذا سوف هذا المطال المطلب في فرعين:

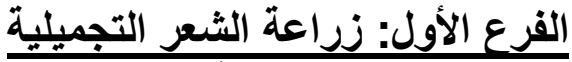

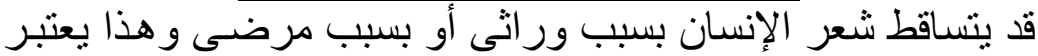
مشكلة عند كثير من الناس لاسيما النساء، و إذا حدث هذا لفا فيمكن معالجته

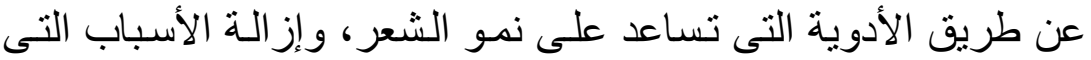

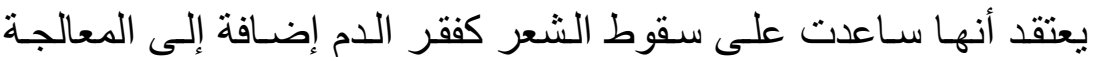

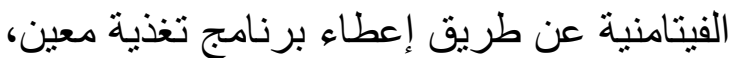

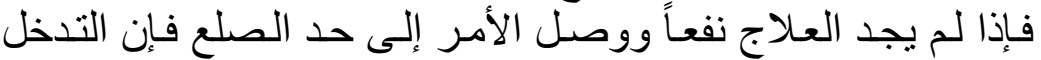

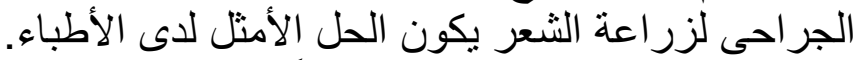

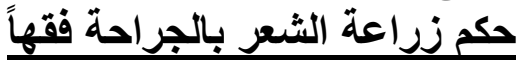

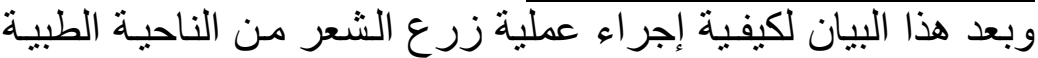

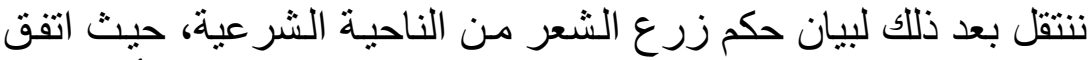

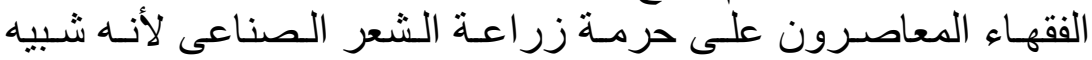

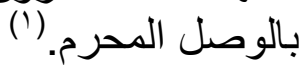

واختلفوا فى زر اعة الثعر الطبيعى على قولين:

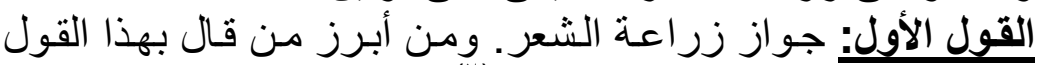

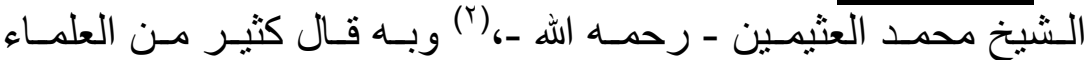

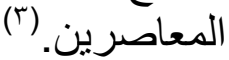

وقد استدلو ا على ما ذهبو إليه بالسنة،و المعقول:

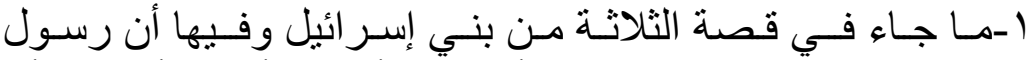

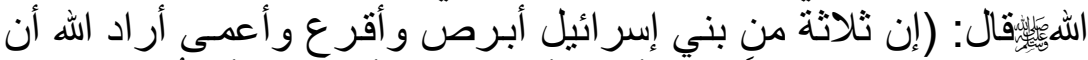

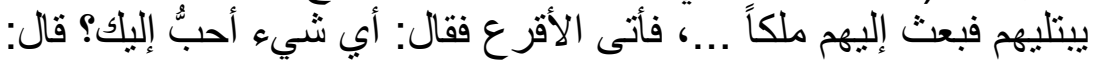

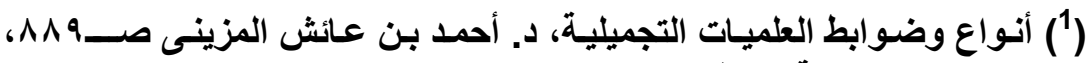

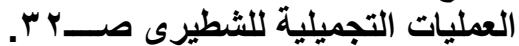

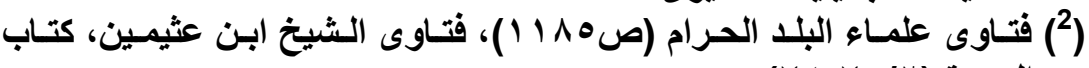

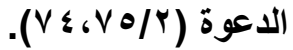

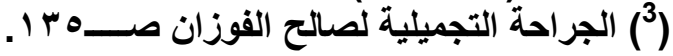
$1 \wedge 9 \leq$ 
شعر حسن ويذهب عني هذا الذي قذرني الناس قال: فمسحة فذهب عنـه

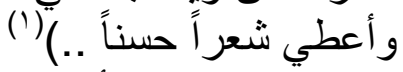

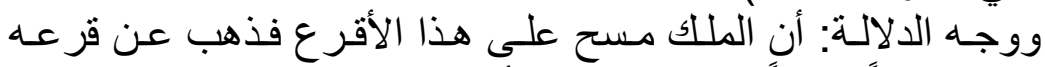

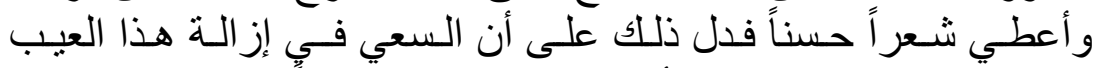

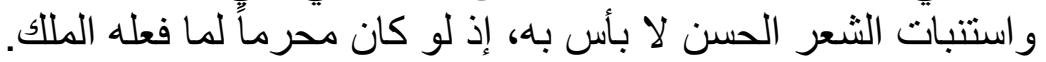

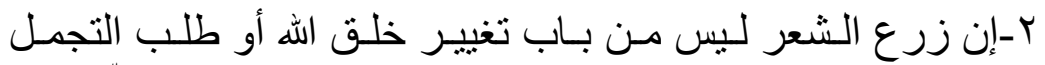

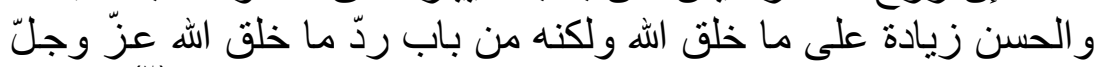

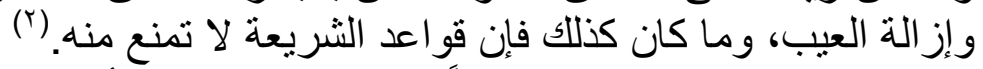

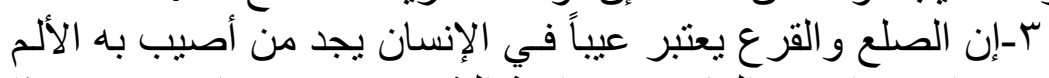

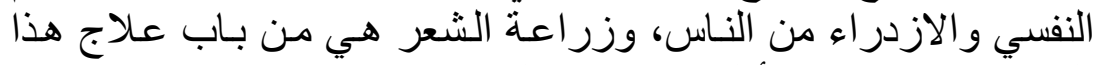

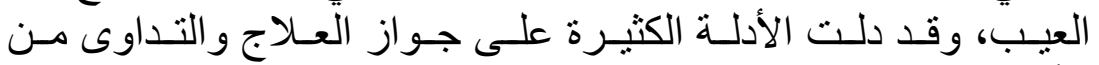

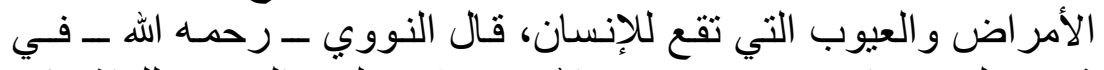

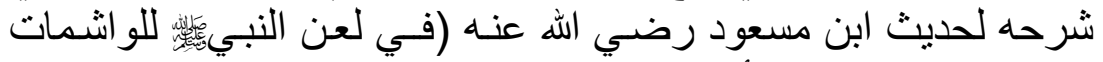

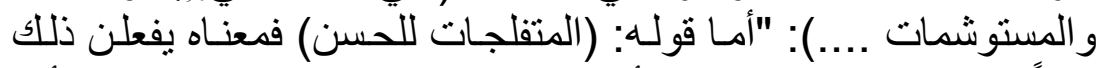

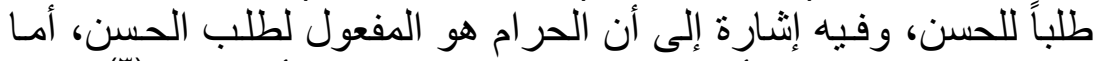

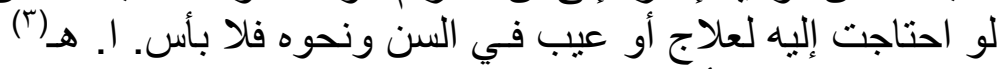

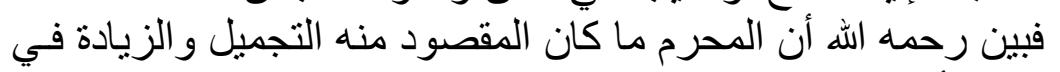

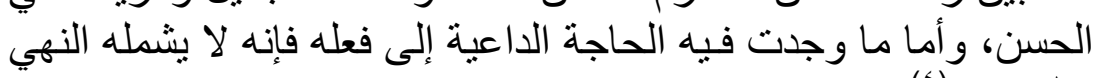

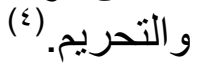

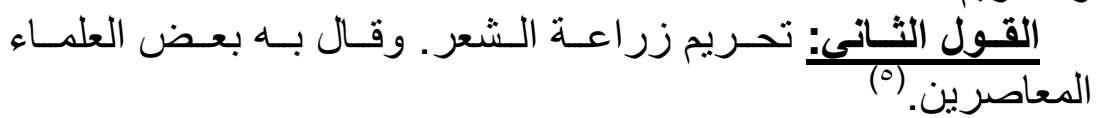
وقد استـلولو أبأن زر اعـة الشعر تدخل في الوصل المحرم شـرعاً فتكون محرمة. آنان

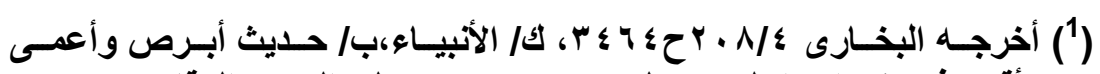

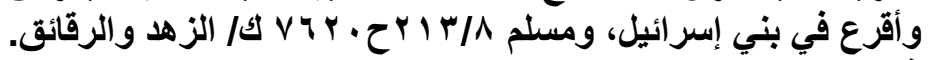

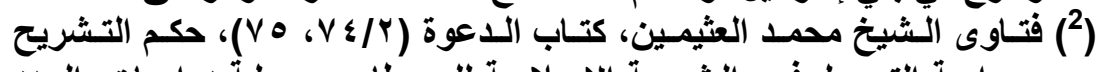

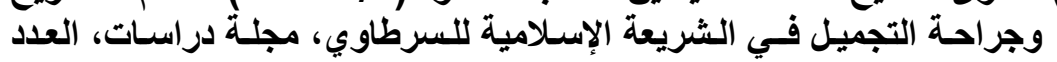

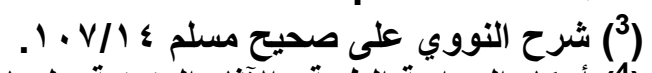

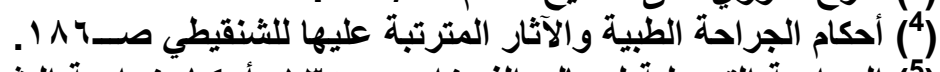

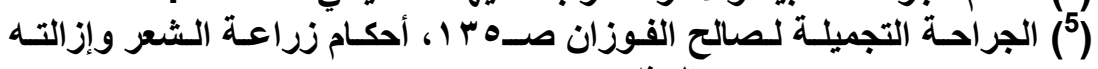

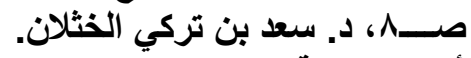

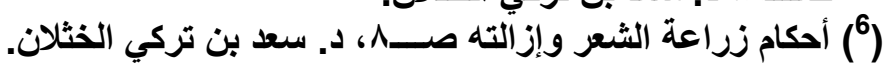
1190 


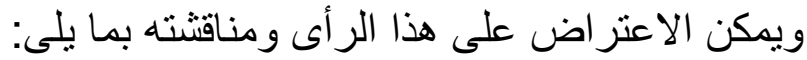

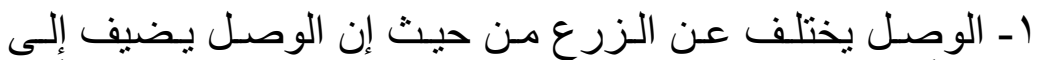

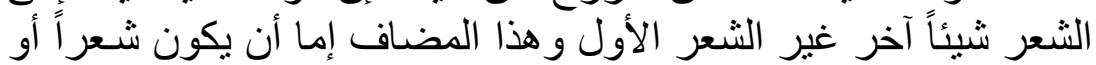

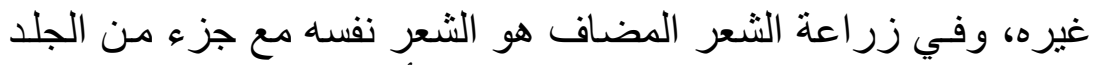

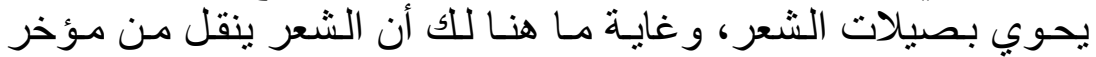

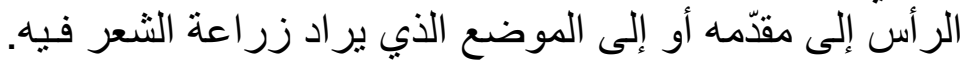

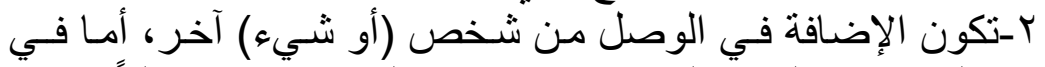

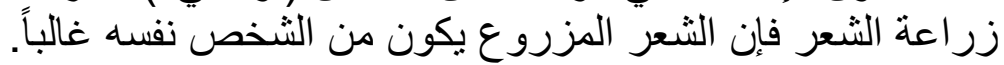

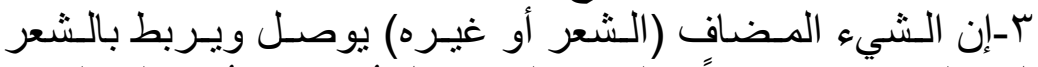

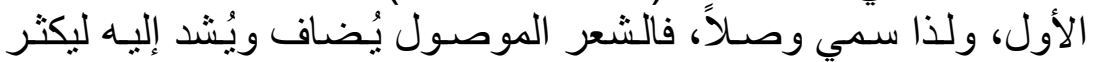

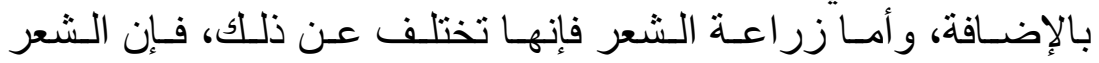

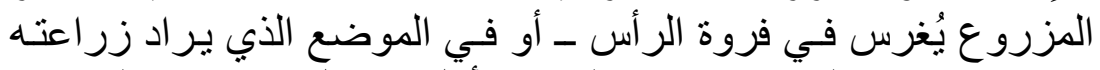

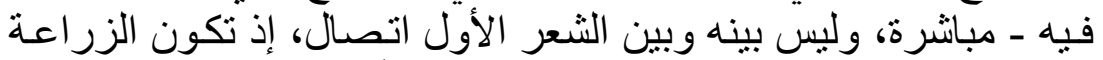
في منطقة خالية أو شبه خالية من الثنعر (غالباً).

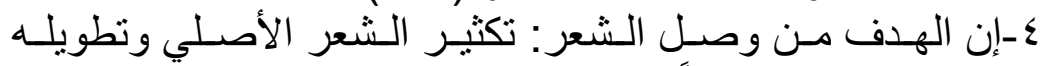

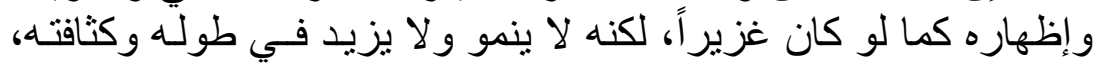

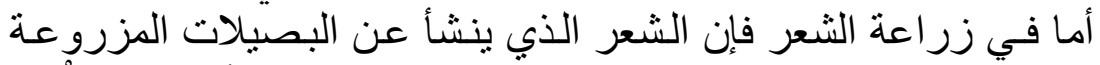

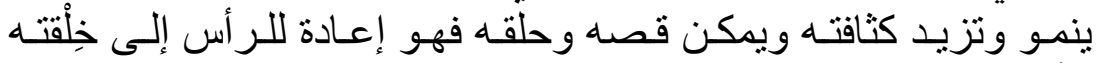

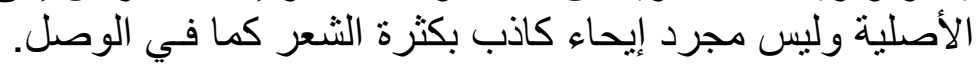

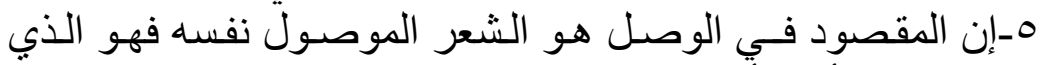

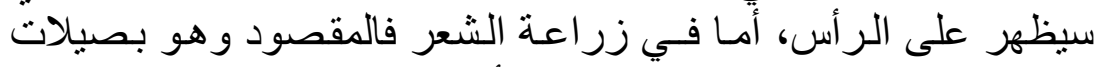

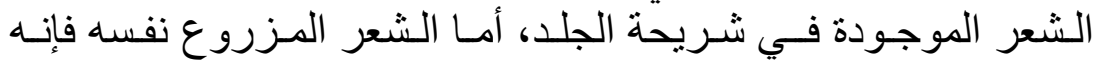

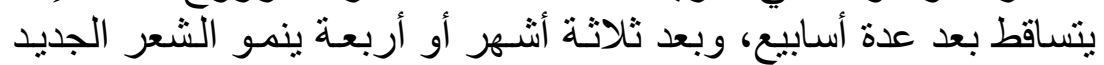
الذي يبقى على الرأس.

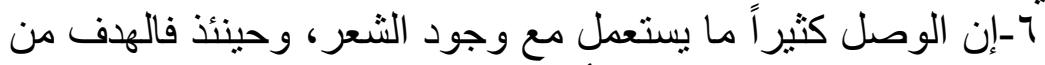

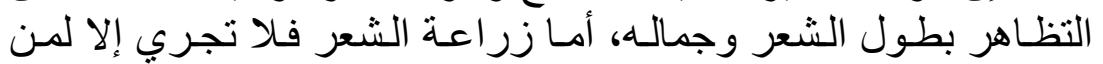

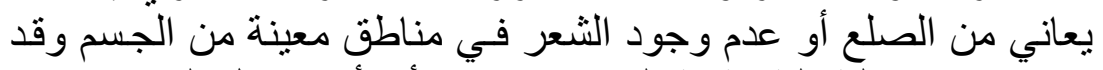

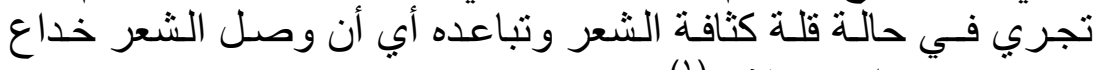

وتغرير ، وزر اعته علاج. (')

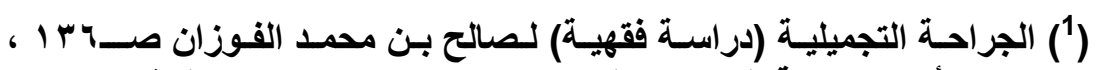

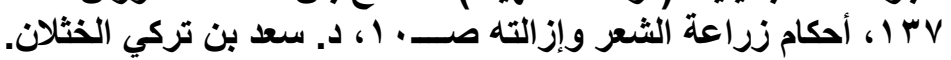


القول الأول القخائل بجواز زر اعة الثعر هو المختار نظراً لقوة أدلته

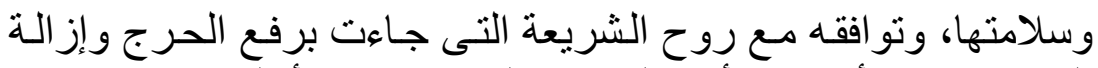

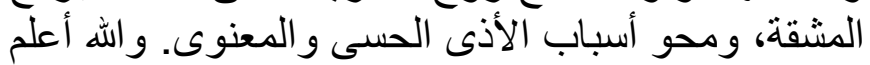
ضوابط زراعة الشعر الجراحية البية التجميلية البنية

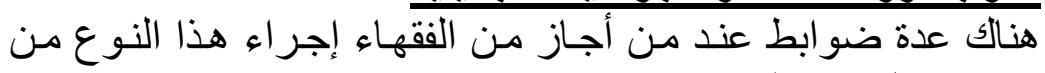

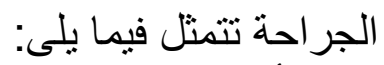

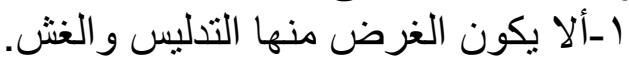

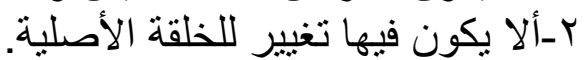
ب-ألا تستعمل فيه مادة نجسة فئه

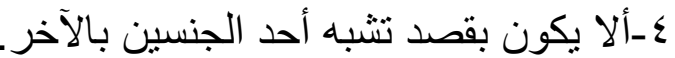

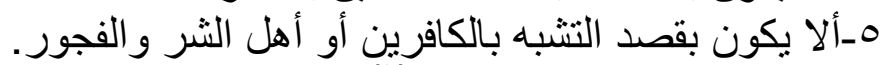

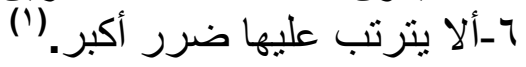




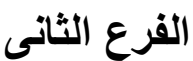 \\ حكم إزالة الثعر بالطرق الطبية الحديثة}

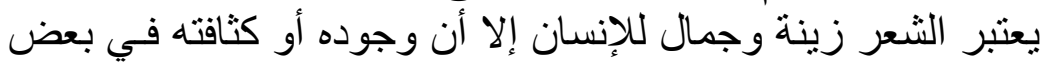

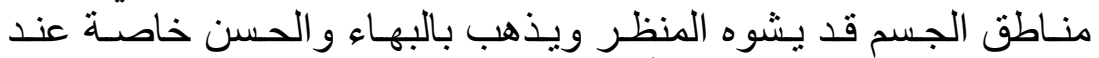
المر أة، كما أنه قد يكون وكر اً لتجمع الأوساخ و القذر في مواضع معينة

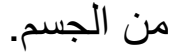

ولهذا فقد تعددت طرق إز الة الشعر، وقد وجد للدى الناس من قديم

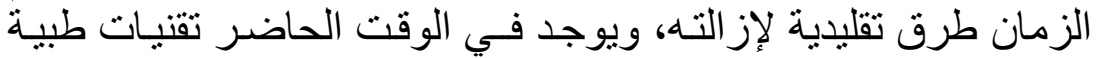

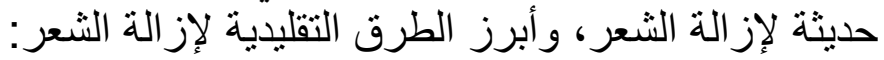

ا-إزاٍ الة الثعر بالحلاقة، وهذه الطريقة هي أثشهر الطرق وأكثرهـا

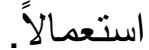

r-إز الة الثعر بالنتف إما باليد أو عن طريق مـا يعرف بالشمع أو

$$
\text { الحلاوة أو غير هما. }
$$

بـا_اقتلاع الثعر بالملقاط، وهذه الطريقة تستخدم لإز الة الشعر القليل

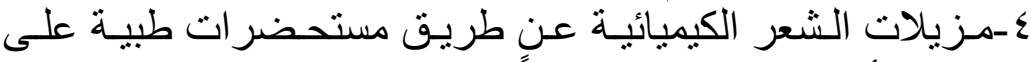

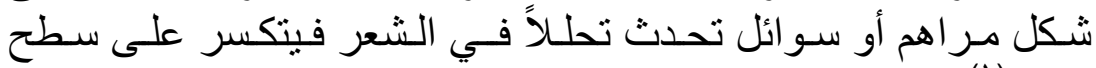

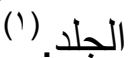

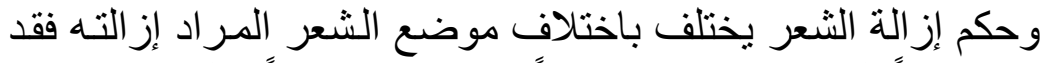

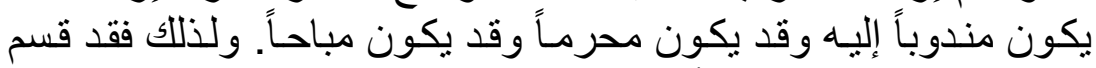

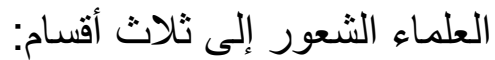

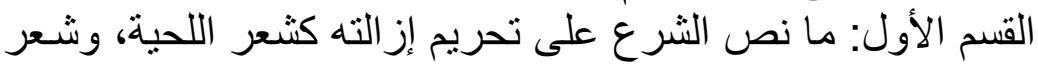

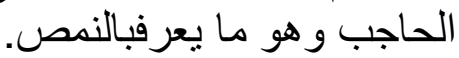

القسم الثاني: ما نص الثر مالن على طلى طلب إز الته كالعانة و الإبط. القسم الثالث: ما سكت عن الشرع كشعر اليدين و الساقين و الفخذين

و البطن و الظهر. (؟)

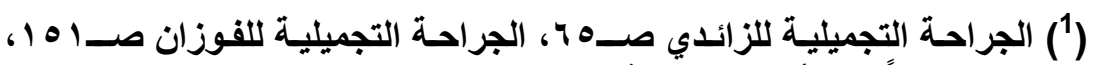

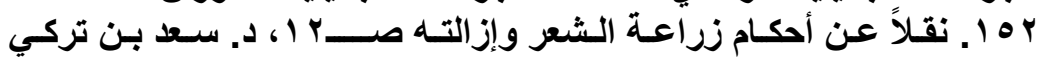

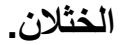

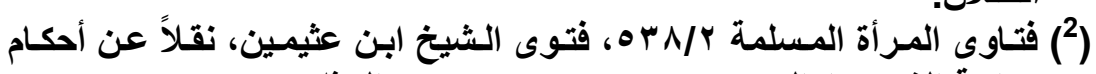

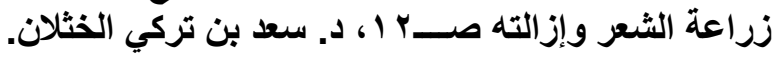
1191 


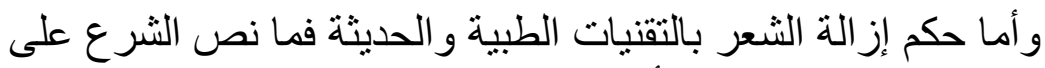
تحريم إز الته فيحرم إز الته بأي مزيل سو اء كاء كان بالتقنيات الطبية الحديثة أو بغير ها، وذلك كثمر اللحية و الحاجيبين. وأما ما نص الثرال الثرع على طلب إزالته فقيه تفصيل:

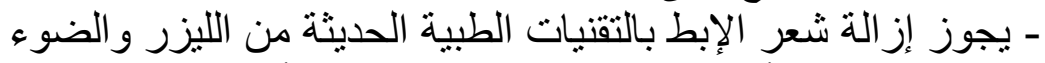

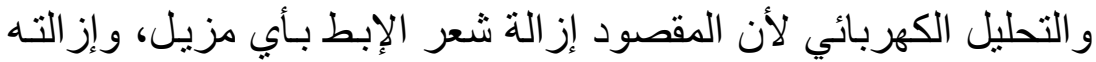
بالتقنيات الطبية الحديثة يحقق هذان المقان المقصود.

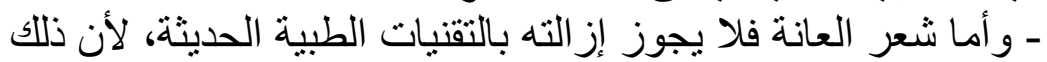

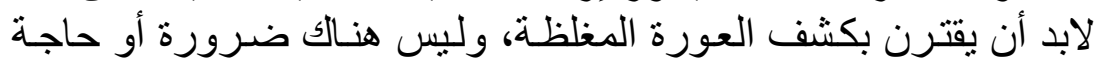

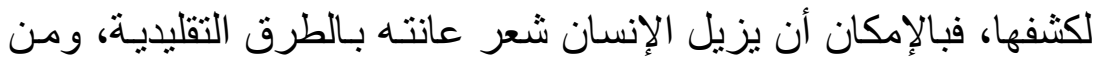

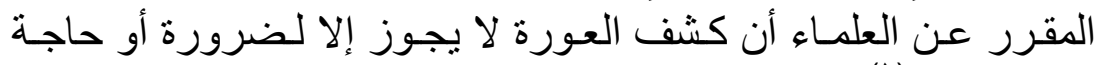

تقتضي ذلك. (1) و وأما ما سكت عنه الشر ع كشعر اليدين و الساقين و الفخذين و البطن

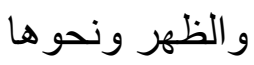

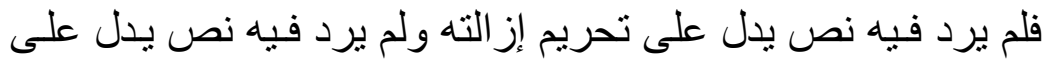

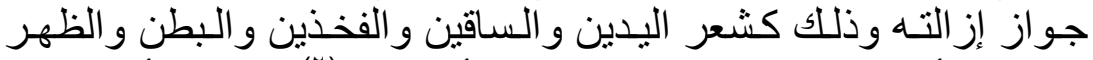

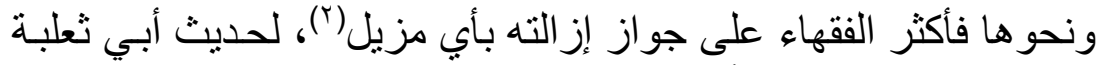

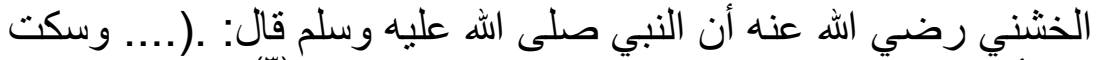

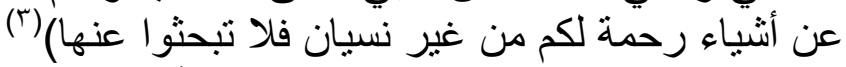

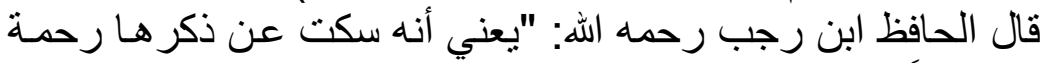

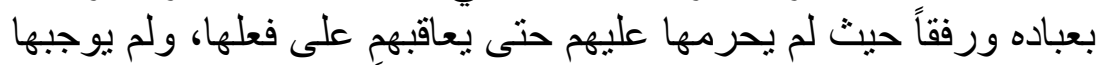

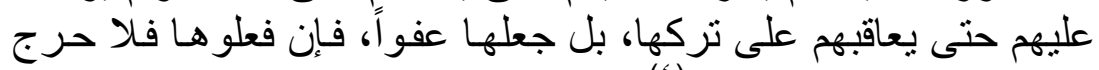

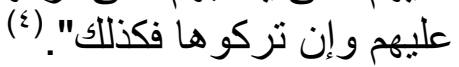

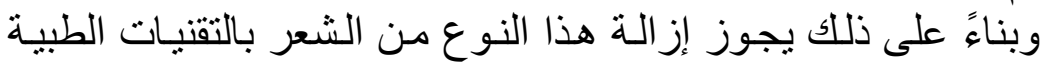

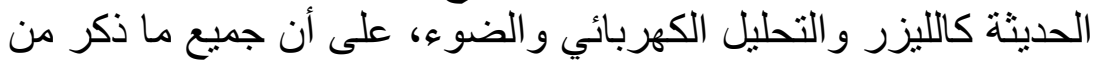

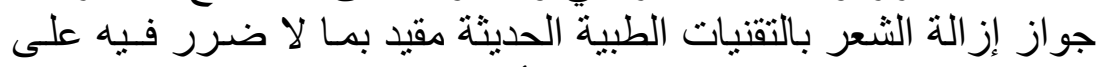

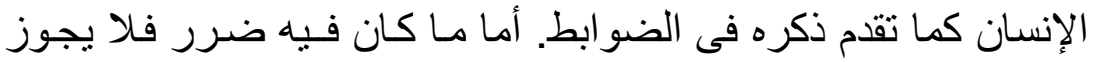

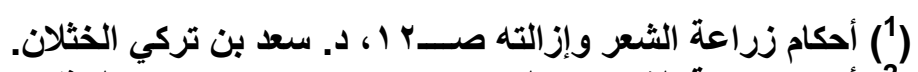

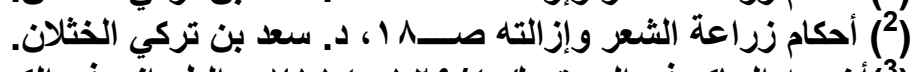

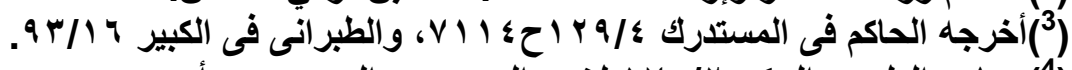

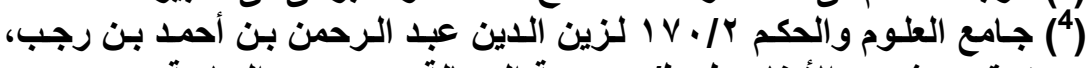
تحقيق: شعيب الأرناؤوط، طا مؤسسة الرسالة - بيروت السئ السابعة. 
أستخدامه خاصة مع وجود البدائل الكثيرة والمتنوعة من المزيلات. و الله

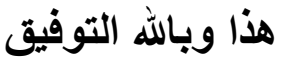

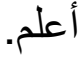

والحمد الله الذى بنعمته تنتم الصالحات 


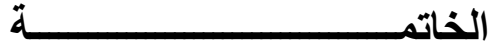

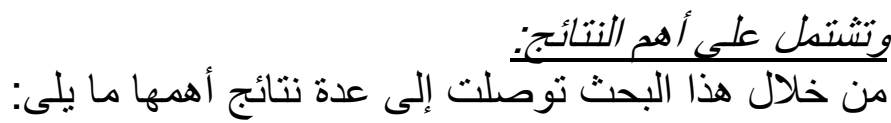

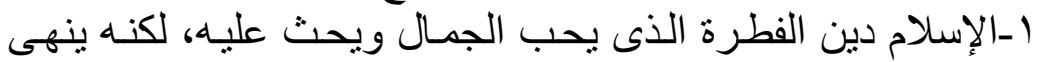

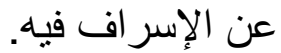

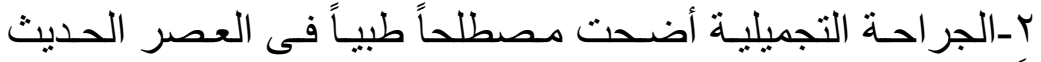

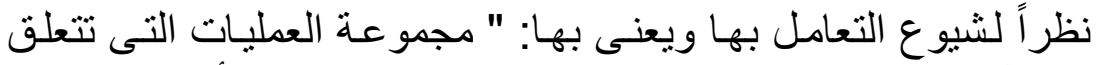

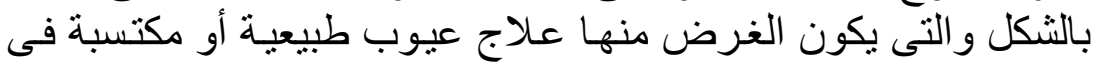

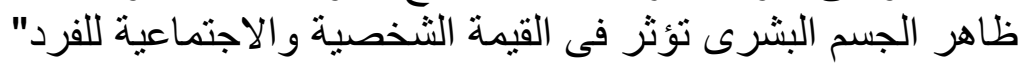

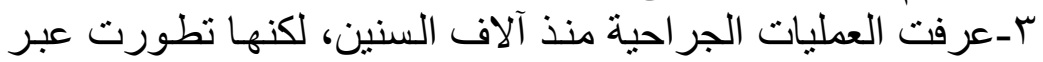
العصور حسب إمكانيات كل عصر حتى وصلت ذروتها في العصر التر

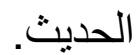

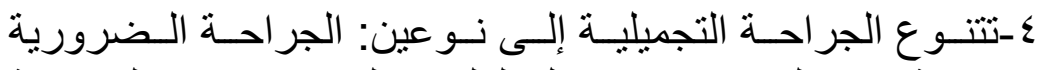

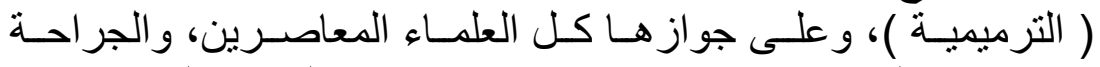

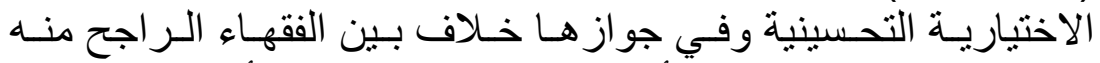

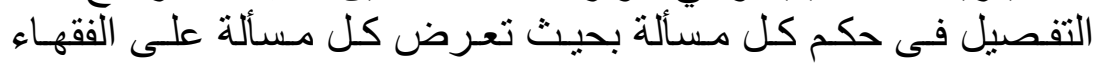

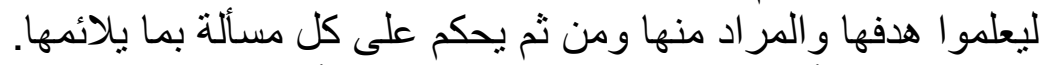

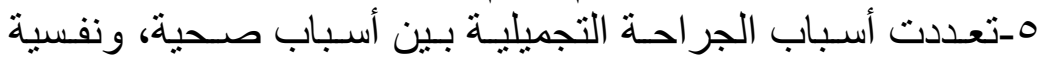

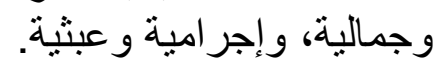

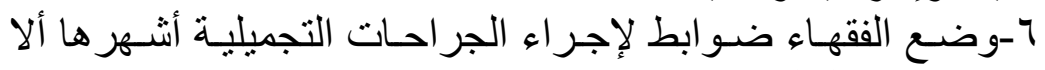
يكون فيها تغيير لخلق الله.

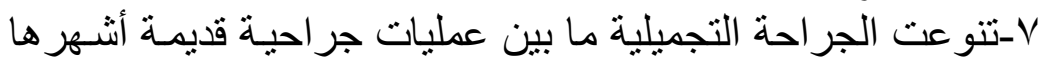

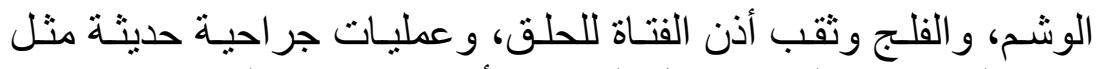

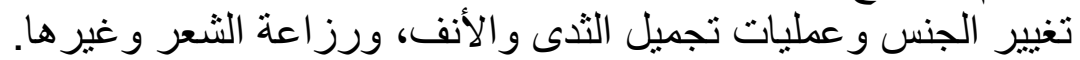

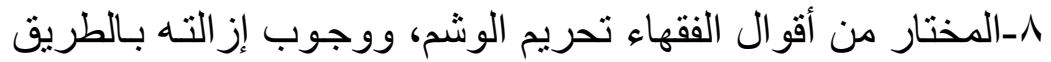
الحديثة إذا أمكن ولم يتضر الفرال النفر صاحبه. و-التفليج و هو التفريج بين الأسنان حرام باتفاق الفقهاء لمـا فيه من

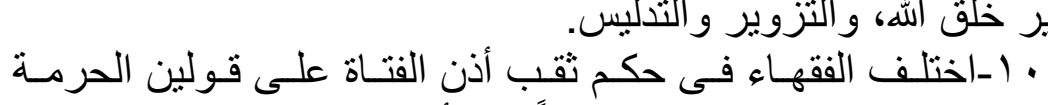
و الجواز، المختار منوما الجواز نظر أل لقوة أدلنه.

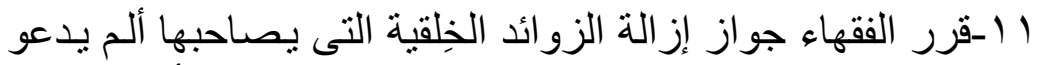
إلى قطعها، واختلفو ا فى الزو ائد الخلقية التى لا يصاحبها التها ألم المختار جواز إز التها لأنه رجوع بالخلقة إلى أصلها. 


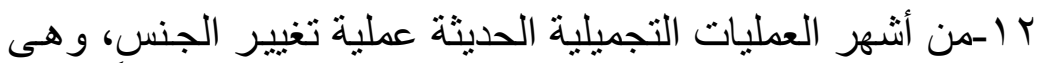

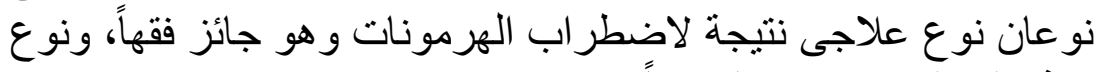
عبثى إجر امى وهو على حرام فقهاً.

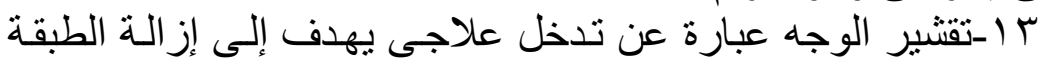
السطحية للبشرة لتتمو طبقة جديدة أكثر نضارة ولتحقيق سطح مستوى، وقد اختلف الفقهاء فيه على قولين المختار منهما جوازه التهاه

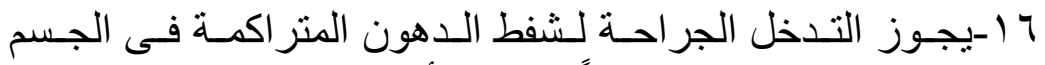

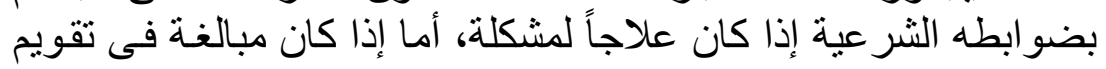

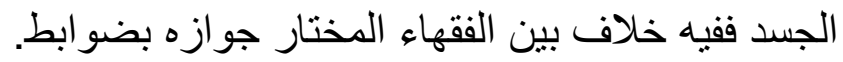

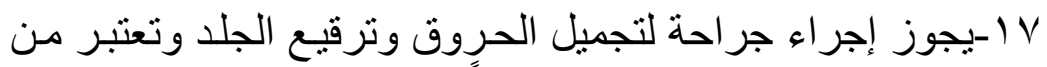

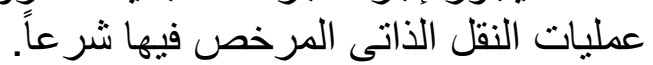

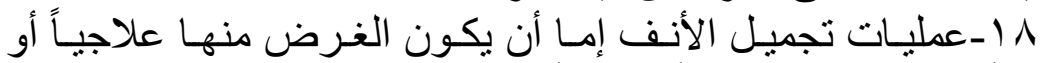

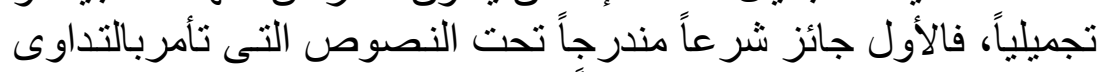

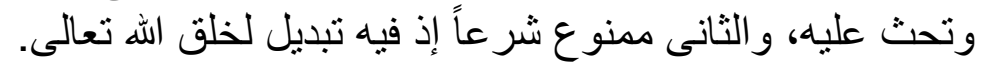

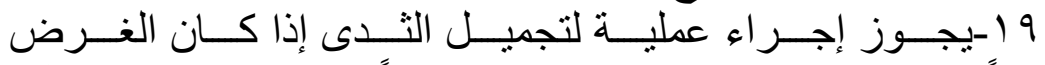
علاجيا،ولايجوز ذلك إذا كان الغرض تجميلياً لهـا فيه من تغيير خلق الفـرض الله.

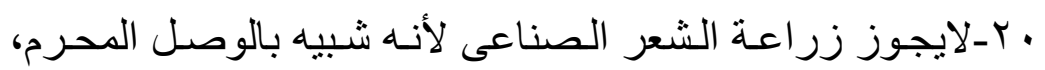

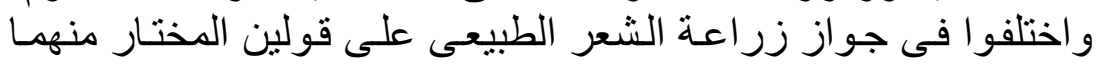

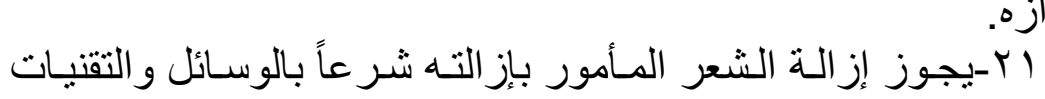

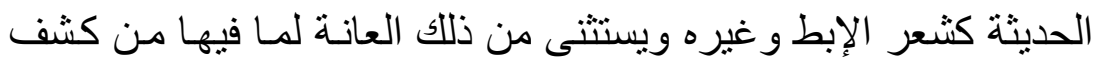

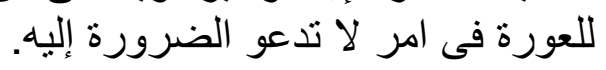

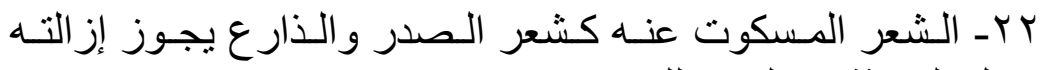
بالوسائل الحديثة كعمليات الليزر وخلافه.

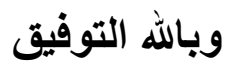




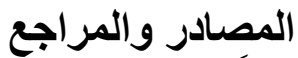

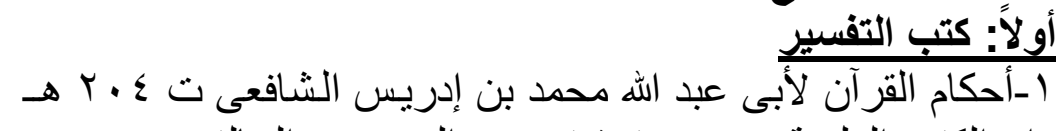
ط/ دار الكتب العلمية بيروت، تحقيق: عبد الغنى عبد الخالق.

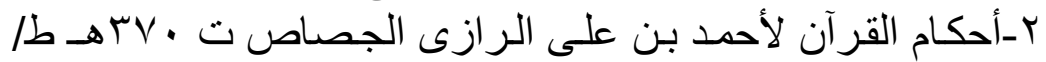

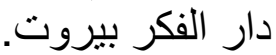

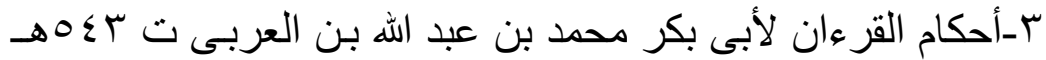

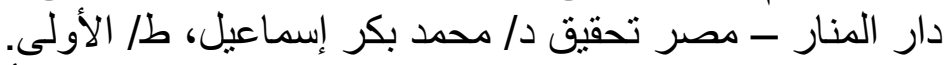

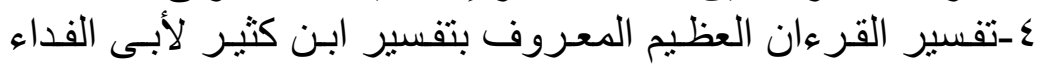

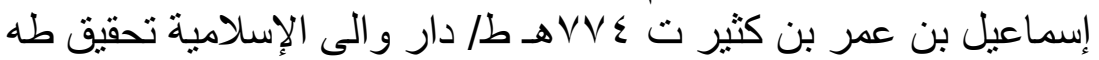
عبد الرؤوف سعد الطبعة الأولى. بن.

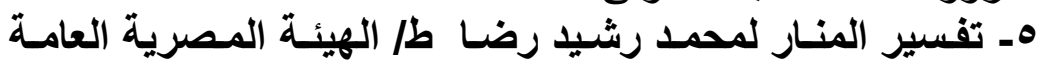

7.الجامع لأحكام القرءان لأبى عبداله محمد بن أحمد القرطبى ت

$$
\text { ( T) }
$$

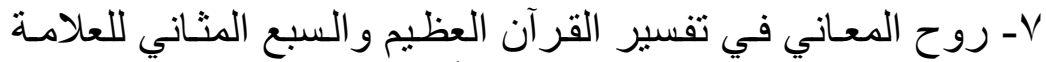

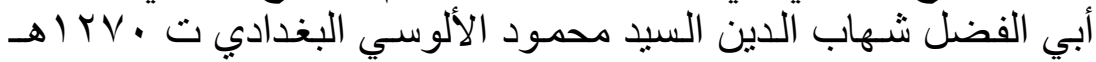

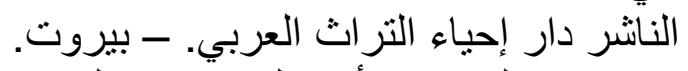

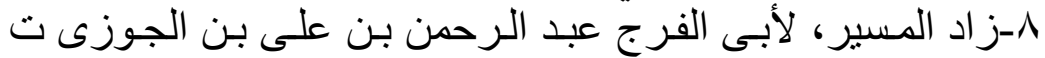

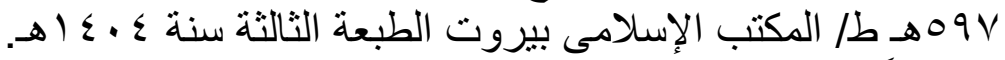

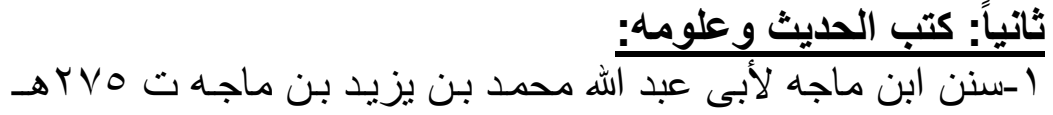

$$
\text { ط/ در الفكر بيروت ابن ماجه لابق محمد فؤاد عبد الباقى. }
$$

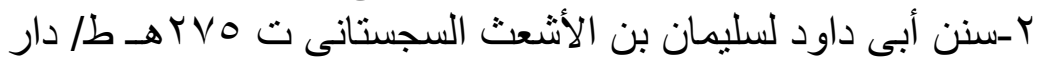
الفكر تحقيق محمد محى الدين دائن عبد الدين الحميد.

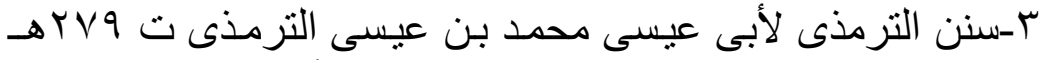

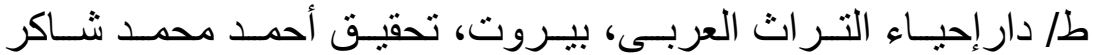

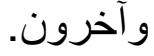
ع -سنن النسائى (المجتبى) لأبى عبد الرحمن أحمد بن شعيب النسائى

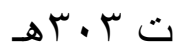
ط مكتب المطبو عات حلب الطبحة الثانية تحقيق عبد الفتاح أبو غدة.

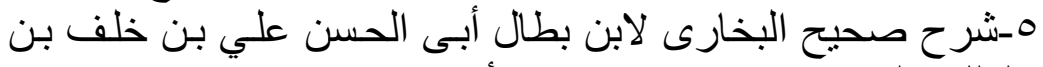

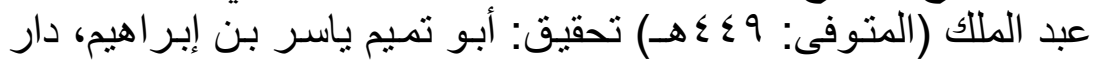


النشر : مكتبة الرشد ـ السعودية، الريـاض، الطبعة: الثانيـة، سبـ اهـ ـ

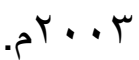

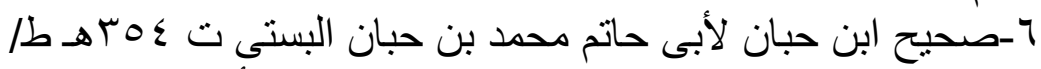

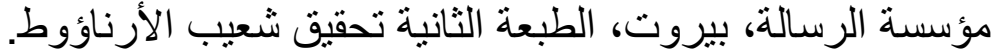

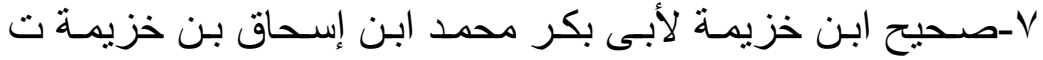

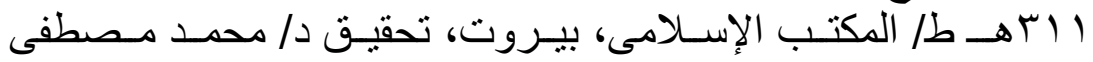
الأعظمى. الأسم.

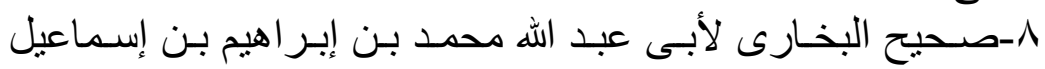

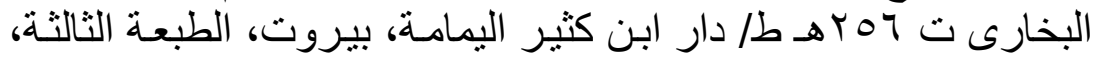
تحقيق د/ مصطفى ديب البخا.

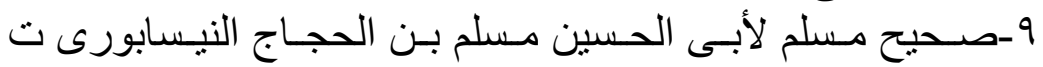

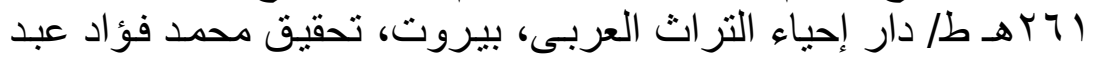

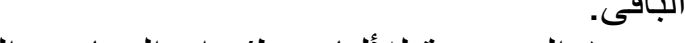

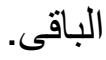

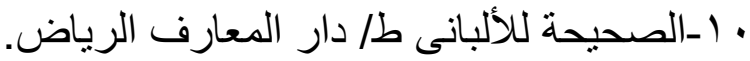

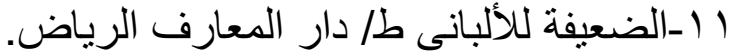

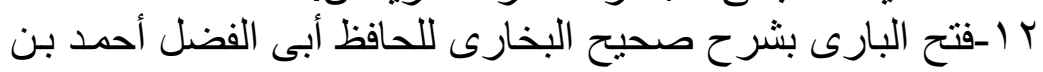
حجر العسقلانى البارى

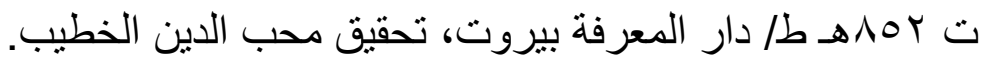
r ا - فيض القدير شرح الجـامع الصغير للمناوى. دار الكتب العلميـة

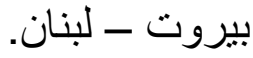

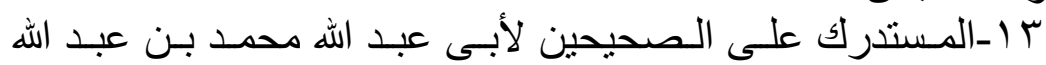

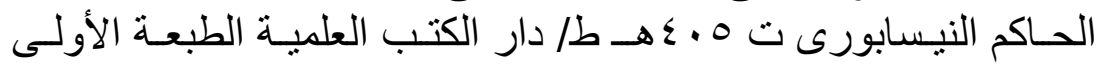
تحقيق مصطفى عبد القادر عطا.

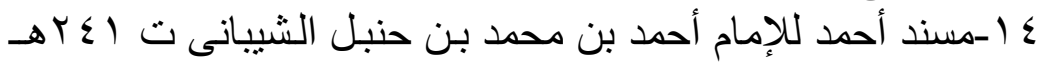
b مؤسسة قرطبة. 0 ـ المعجم الكبير للإمام سليمان بن أحمد الطبرانى طل مكتبة العلوم والحكم تحقيق حمدى عبد المجيد السلفى.

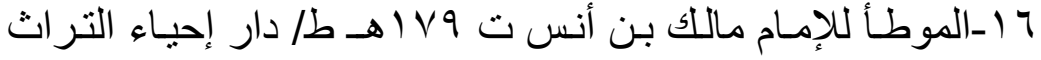

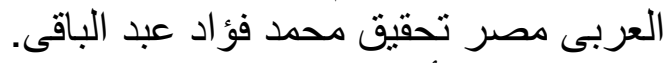

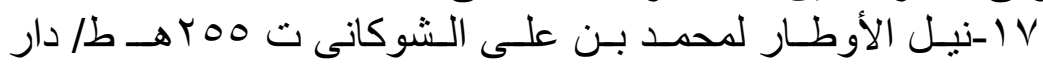
الحديث الطبعة الر ابعة تحقيق عصام الدين الصبابطى. لـنى 


\section{ثالثاً: كتب قو اعد و أصول الفقه:

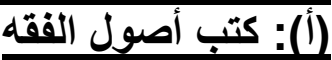

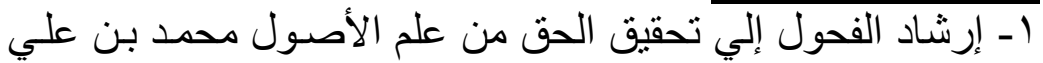

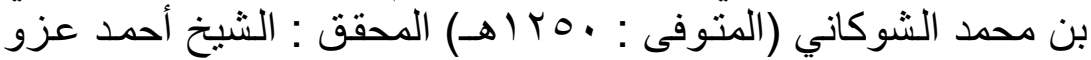
عناية ، دمشق -الناشر : دار الكتاب العربي الهي

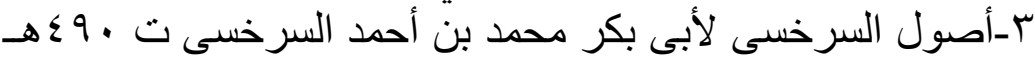
ط/ دار المعرفة بيروت. 0ـالبحر المحيط لبدر الدين بن محمد بن بهادر الزركشى طا دار

جـالبرهـان فـى أصـول الفقه لإمـام الحرمين عبد الملك بـن عبد الله

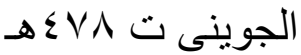

طا دار الوفاء، المنصورة، مصر، ط الر ابعة تحقيق/ عبد العظيم

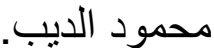
Vار-التقرير والتحبير فى شرح التحرير لمحمد بن محمد بن أمير حساج

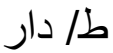
الكتب العلمية.

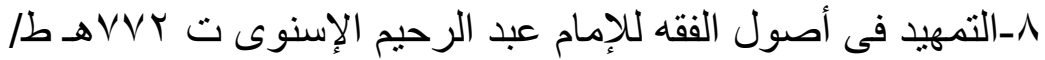
مؤسسة الرسالة.

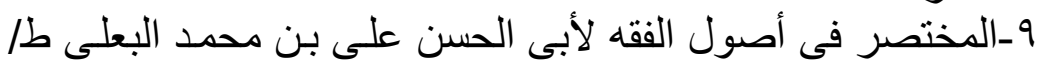
جامعة الملك عبد العزيز مكة المكرمة ـ تحقيق: محمد مظهر بقا. (ب): كتب القواعد الفقهية

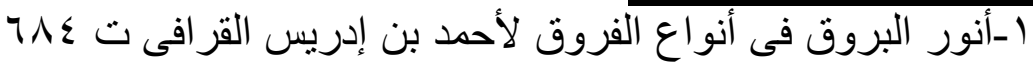

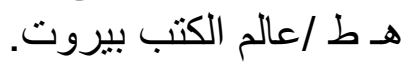

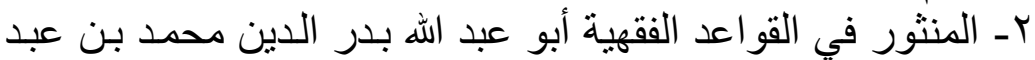

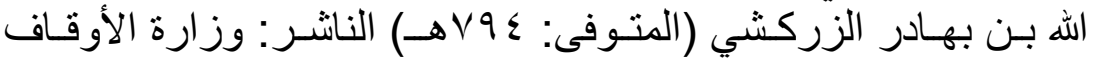

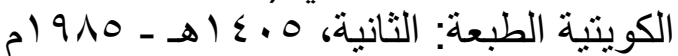

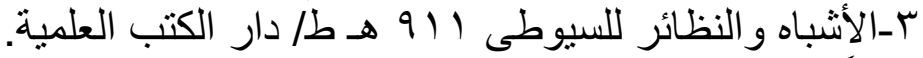

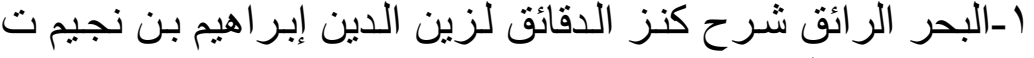

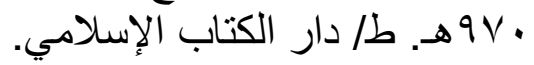

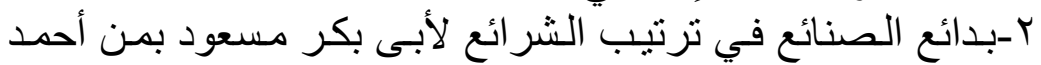
الكاسانى. طا دار الكتب لع العلمية. 
r-تبيين الحقائق شرح كنز الدقائق لعثمـان بن على الزيلعى طا دار

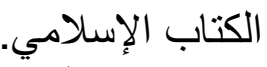

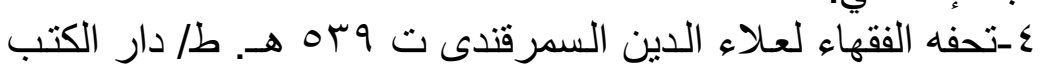

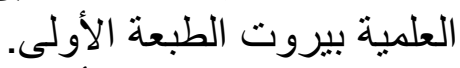
هـالجوهرة النيرة لأى بكر محمد بـن على العبادى. طا المطبعـة

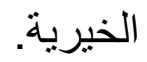
ج-درر الحكام شرح غرر الأحكام لمنلاخسرو. ط/ دار إحياء الكتب

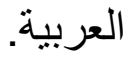
طار-رد المحتار على الدر المختار لمحمد أمين المعروف بابن عابدين.

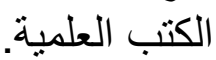
ط/ - مار 1ـالعناية شرح الهاية لمحمد بن محمود البابرتى. ط/ دار الفكر.

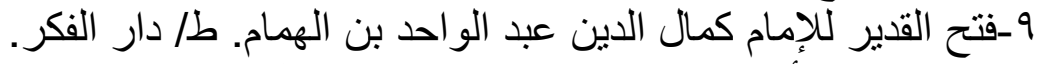

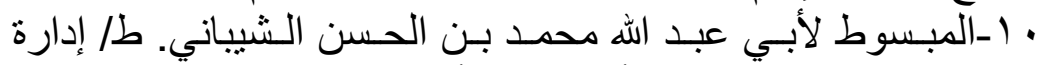

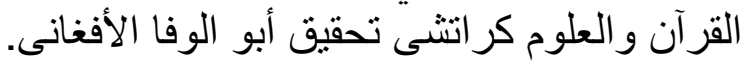
(ب) مر اجع: الفقه المالكي: ا-بداية المجتهد لأبي الوليد أحمد بن محمد بن رشد الحفيد ت

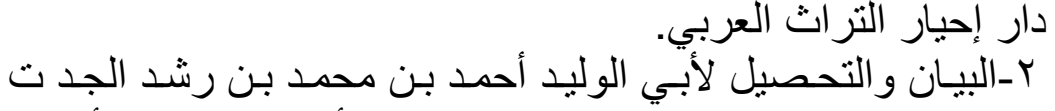

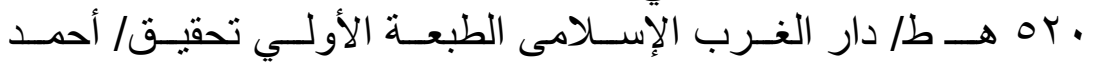

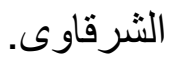
بـالثــر الدانى شـرح رسـالة القيرواني للإمـام صـالح عبد السميع الأبي الأزهرى. ط/ المكتبة الثقافية.

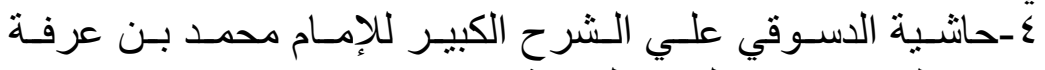
الدسوقي. طا دار إحياء الكتب العربية. 0-حاثشية الصاوى على الشرح الصغير للإمـام أبي العباس أحمد

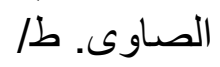

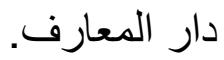
דالـالذخيرة للإمـام أحمد بن إدريس القرافي ط دار الغرب بيروت تحقيق محمد حجي. V-شرح مختصر خليل للإمـام محمد بين عبد الله الخرشي ط/ دار 
A-الشرح الكبير لأبي البركات أحمد الدردير ط/ دار الفكر تحقيق

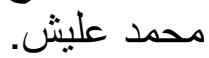
9-الفو اكه الدو انى للإمـام أحمد بن غنيم النفر اوى ت هب | 1 اهـ طا

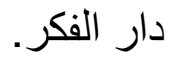

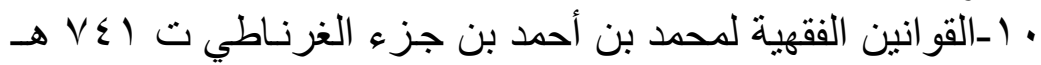

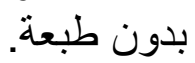

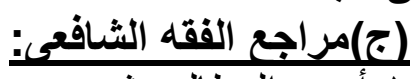

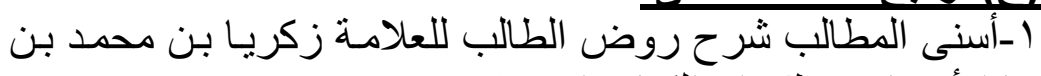

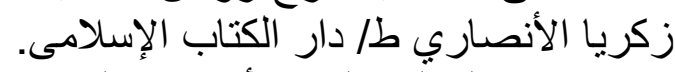

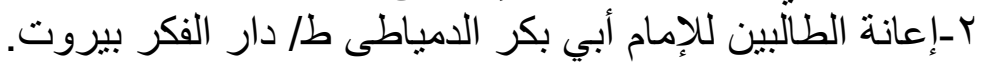

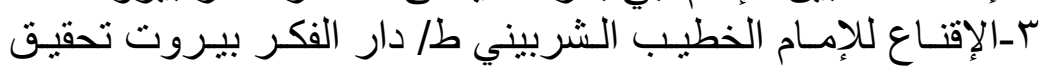

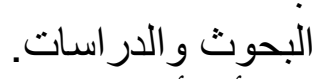

ـ ـ-الأم لأبي عبد الله محمد بن ادريس الشافعى ت ؟ • ب هـ ط/ دار

ه-تحفة المحتاج في شرح المنهاج للإمام أحمد بن محمد بن حجر الهيتمي طا دار إحياء ألتراث العرح العني.

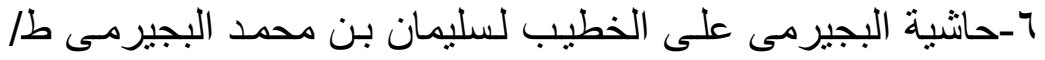

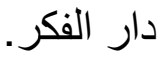
Vالكراثية البجيرمى على المنهج لسليمان بن محمد البجيرمى ط/ دار

1-حانشية الجمل للإمام سليمان بن منصور الجمل طا دار الفكر.

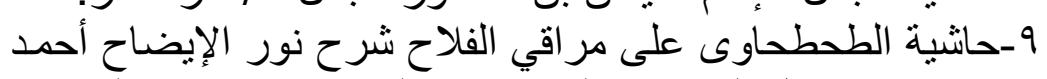

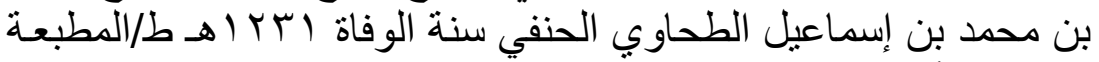

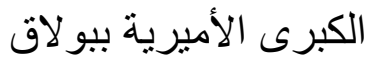
• إ-حاثية قليوبى وعميرة للإمـام أحمد بن سلامة القليوبى وأحمد

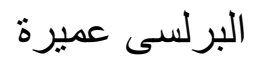
طا دار إحياء الكتب العربية.

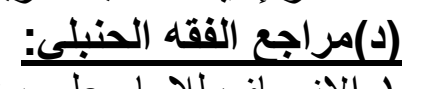

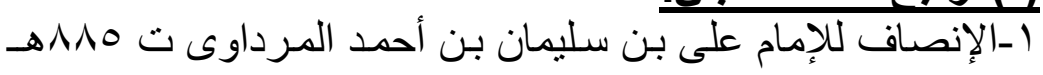
ط/ دار إحياء التراث العربي. 


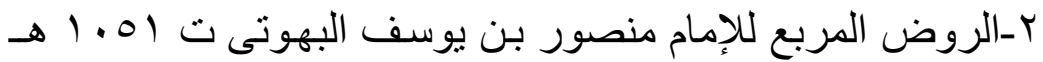

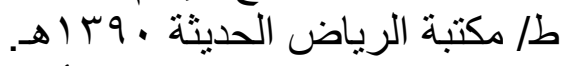

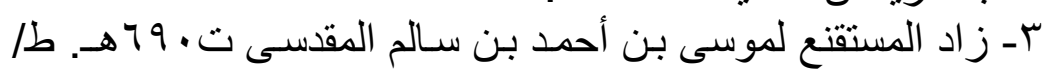
مكتبة النهضة الحديثة مكة المكرمة.

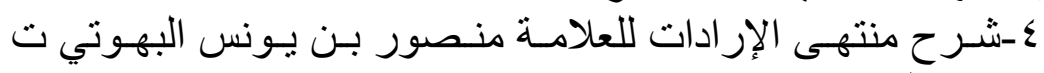
1.01 عالم الكتب. 0ـالكافى في فقه ابن حنبل لأبي محمد بن قدامة المقدسى ط/ المكتب الإسلامي بيروت.

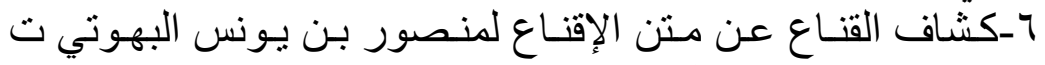

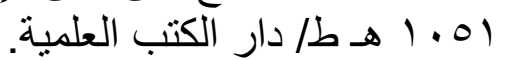

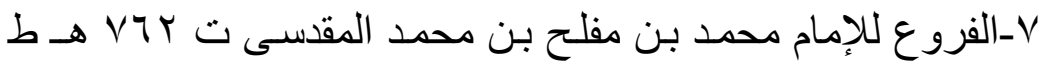
عالم الكتب. 1_ا-المبدع للإمام أبي اسحاق إبر اهيم بن محمد بن عبد الله بن مفلح ت

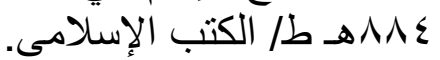

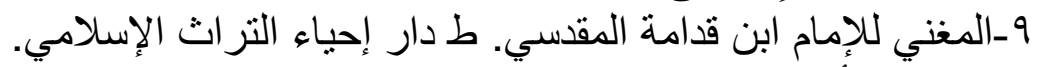

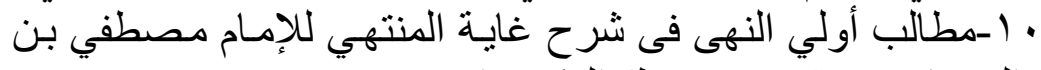

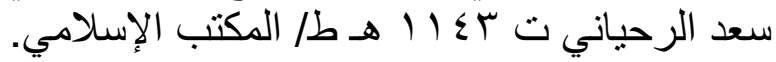

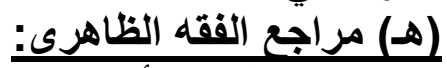

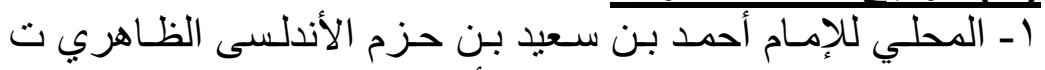

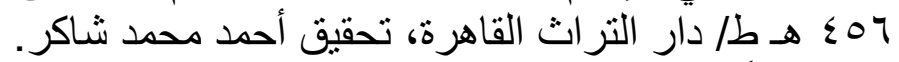

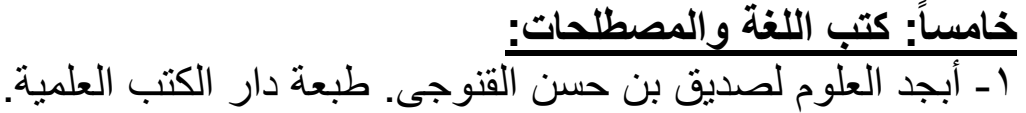

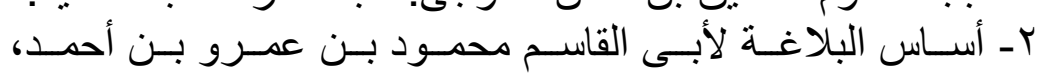

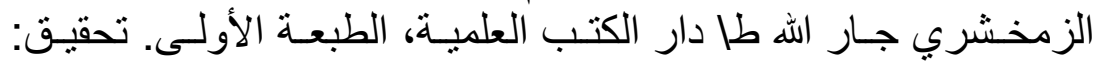

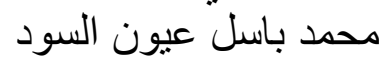

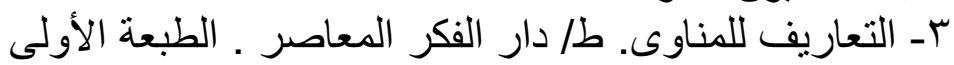

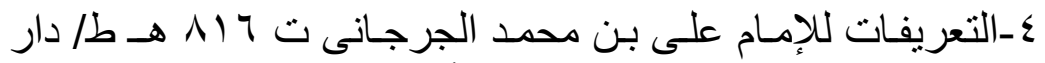
الكتاب العربي بيروت 0 ـ ـ أهـ الطبعة الأولي تحقيق إبر الهيم الإبياري.

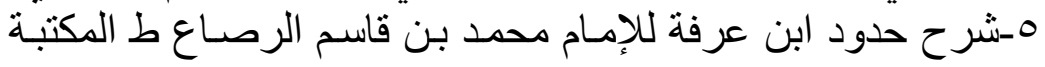
العلمية. T- الصحاح فى اللغة لإسماعيل بن حمـاد الجوهري ، طائه دار العلم للملايين- بيروت.الر ابعة- يناير . 99 الإعل بن 19. $19 \cdot 1$ 
^القاموس الفقهى د. سعدى أبوجيب طا دار الفكر دمشق.

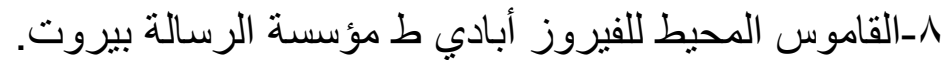

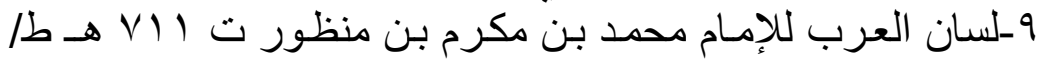
دار صنادر بيروت الأولي.

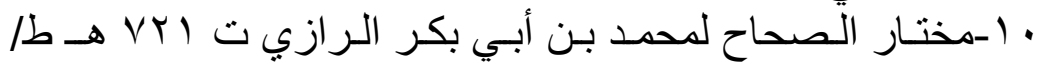
مكتبة لبنان ناشرون بيروت.

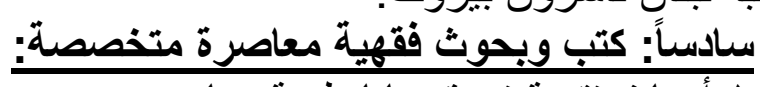

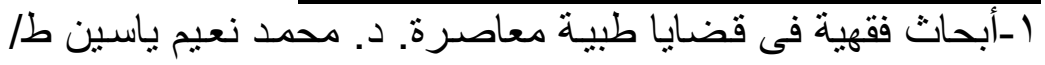
دار النفائس. Y-أجهزة الإنعاش وحقيقة الوفاة بين الفقهاء والأطباء. بحث للدكتور

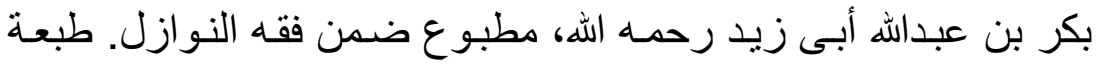
ץ-أحكام تجميل النساء في الشريعة الإسـلامية، د. ازدهـار محمود صابر، طار دار الفضبلة. ع ـأحكام التجميل فى الققهـ الإسـلامى، د. شـعبان الكومى أحمد، طا دار الجامعة الجديدة. 0ـ أحكام التصوير في الفقدة الفيه الإسلامى. لمحمد بن أحمد على و اصل. ط/ دار طيبة للنشر و التوزيع.

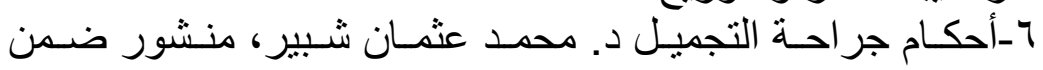
در اسات فقهية فى قضايا طبية معاصرة. طا دار النفائس.

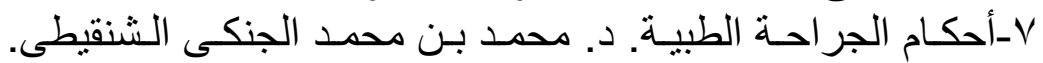
مكتبة الصحابة- الإمار ات اتهات.

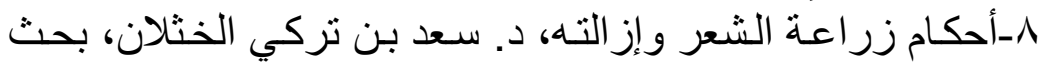

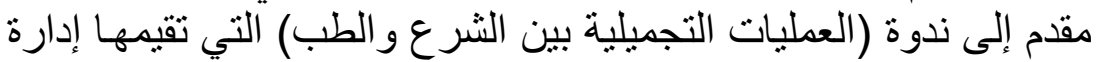

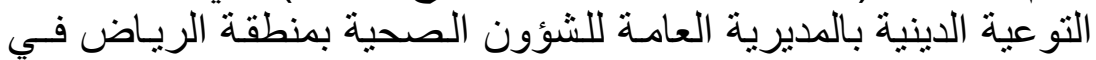

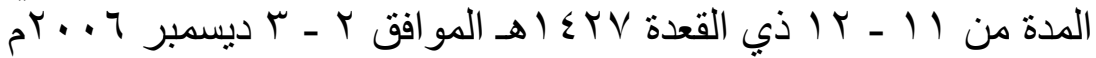

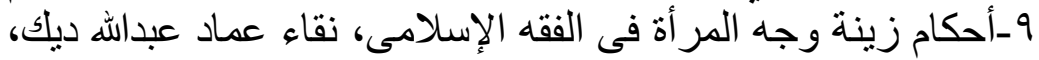
رسالة ماجستير بجامعة النجاح الوطنية الونية بنابلس.

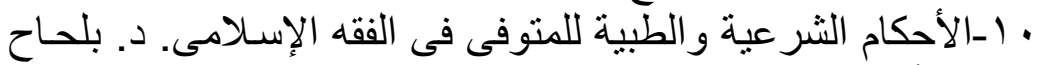

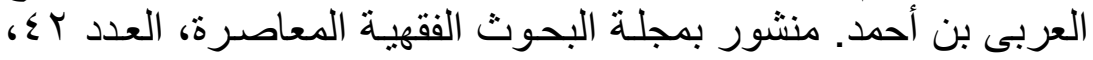


| (الأحكام الشر عية للأعمـال الطبيـة، د. أحمد شـرف الدين، طا

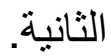
كا ـالأحكام الطبيـة المتعلقة بالنساء فـى الفقهـ الإسـامى ، د. خالد محمد منصور، طا دار الإن النفائس.

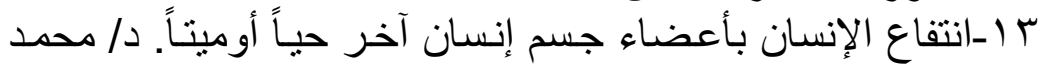
علي البار منشور بمجلة المجمع الفقهى الدولى.

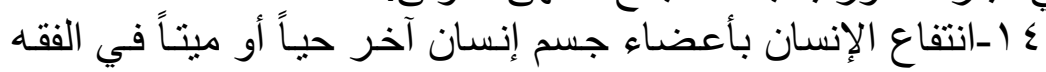

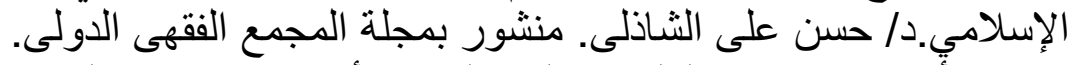

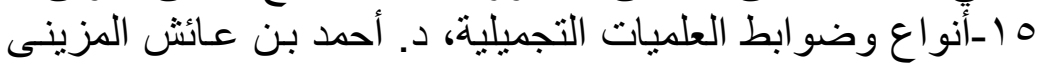

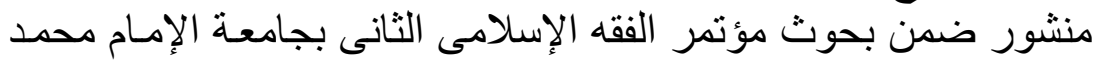

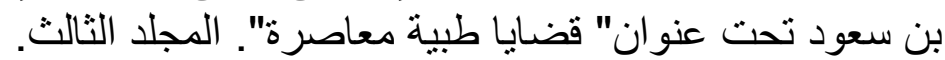

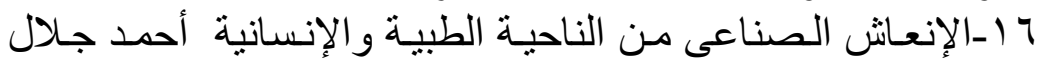

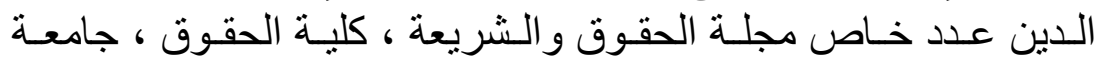
ا ا-تجميل الثدى أحكام وضوابط شرعية د. عبدالرحمن بن أحمد

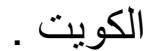
1 ا - تحفة الودود بأحكام المولود لابن القيم، طا دار الريان للتراث.

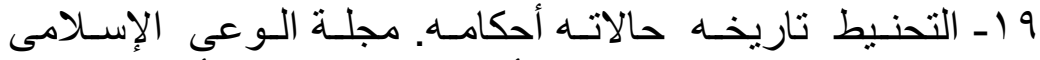

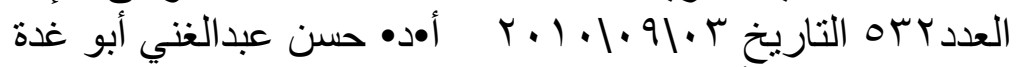

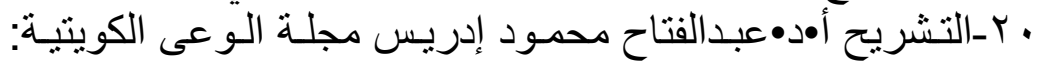

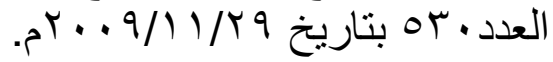

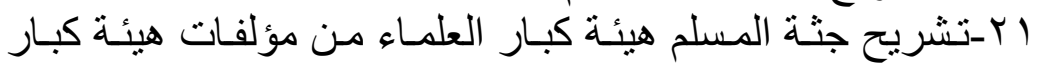

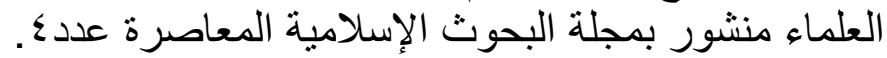

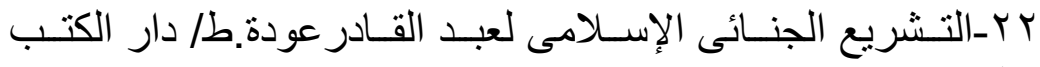

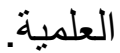

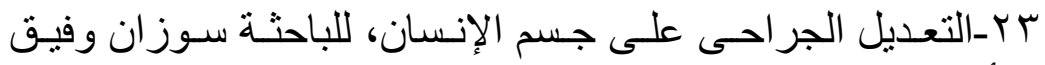
محمد أبومطر، بحث تكميلى للحصول على على درجة الماجستير من كلية لإنة

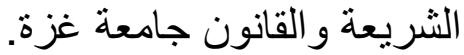
ع ז-تعريف أهل الإسلام بأن تقل العضو حرام للغهـارى. ط/ مكتبة

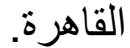

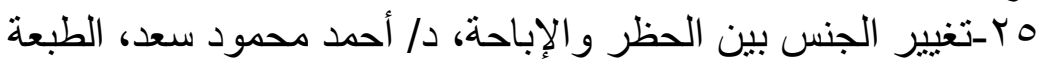

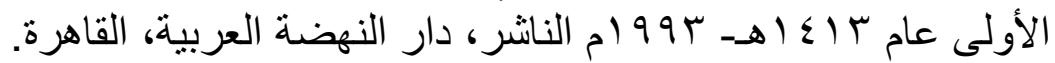


هـ الجر احـة التجميليــة د. مـصطفى الزائدى، طا الــدار الدوليـة للاستمثار ات الثقافية. جب-الجر احة التجميلية ضو ابطها و التكييف الفقهى لها، د. عبدالستار

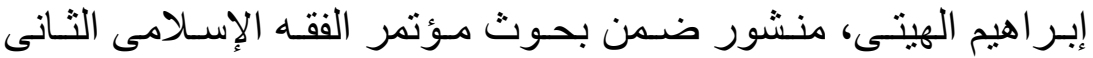

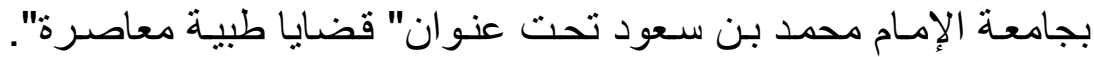

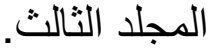

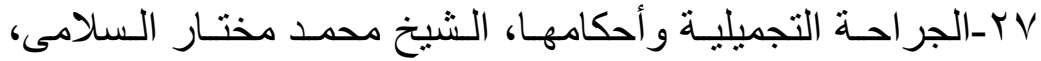

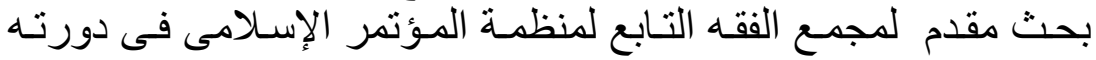
الثامنة عشرة.

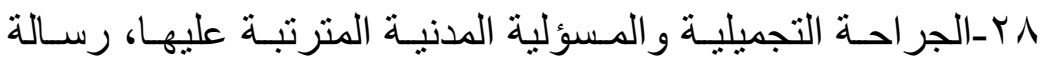

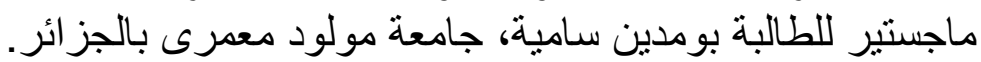

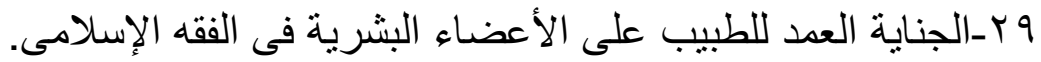

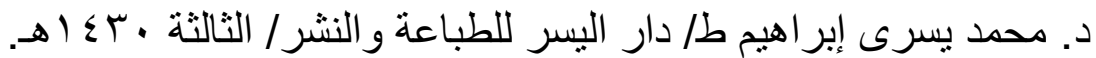

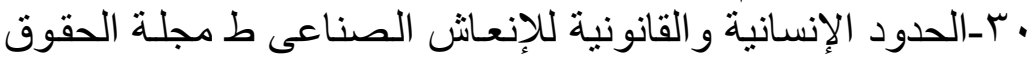
و الثريعة ، كلية الحقوق و الثريعة جامعة الكويت.

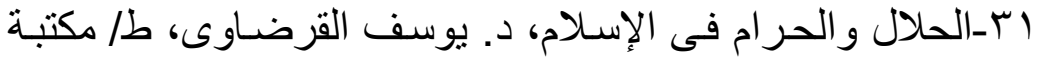

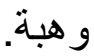
7 ا احقيقـة المـوت و الحبـاة د/ توفيـق الـواعى بحـث منشّور بمجلـة

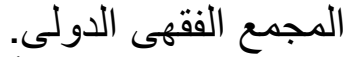

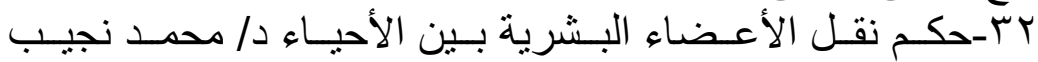
عوضين. دار النهضة العربية. بس-الخطأ الطبى الجر احسى، المستشار منير ريـاض حنـا، ط/ دار ع ب-در اسات فقهية فى قضايا طبيـة معاصرة. مجمو عـة أسـاتذة. طا

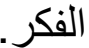
دار النفائس . ماعزات

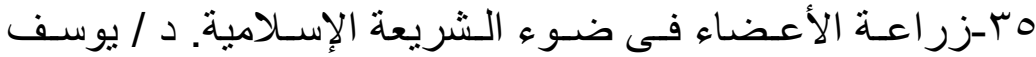

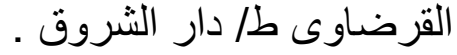
جس- زر اعة الغدد التناسلية والأعضاء التناسلية د/ محمد على البار منشور بمجلة المجمع الفقهى الدولى. الفي. VY الثريعة الإسلامية و الفنون أحمد مصطفى على القضاة. طا دار 


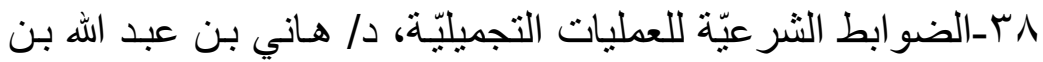

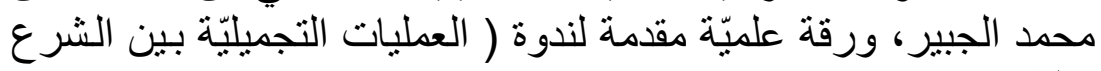

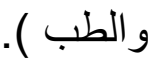

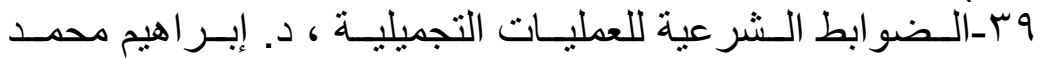
قاسم،منشور ضمن بحوث مؤتمر الفقه الإسـلامى الثانى بجامعـة الإمـام

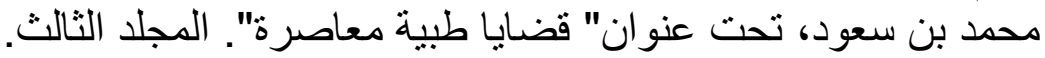

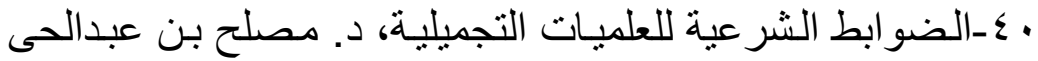

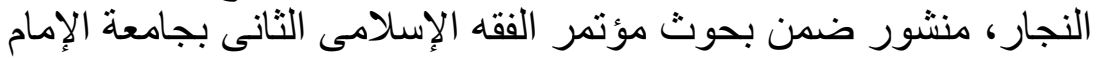
محمد بن سعود، تحت عنو ان" قضايا طبية معاصرة". المجلت الته الثالث.

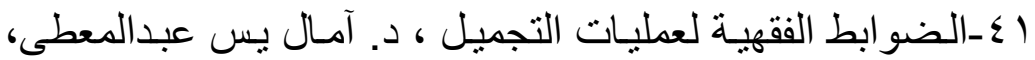

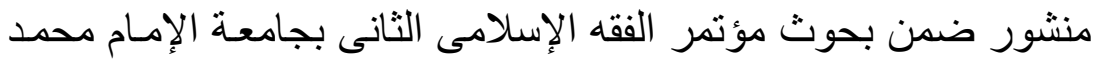

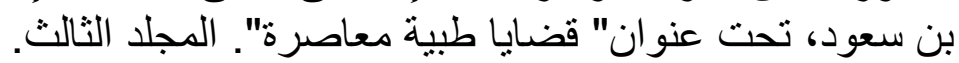

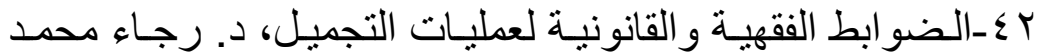

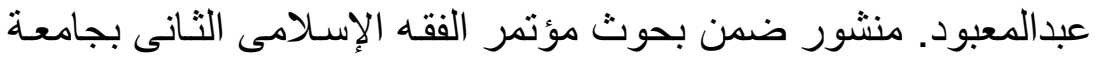

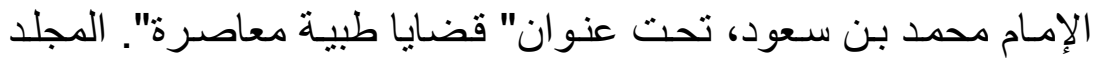

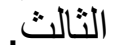
بـ ـالطبيب أدبه وفقهه د/ زهير أحمد السباعى، ومحمد على البار

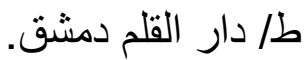
؟ ـــبيعة المسؤلية و التزام الطبيب فى الجر احة التجميلية، د. محمد

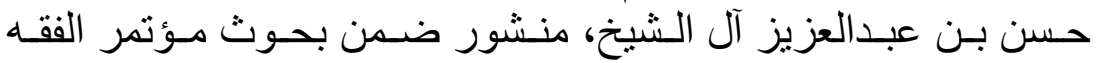

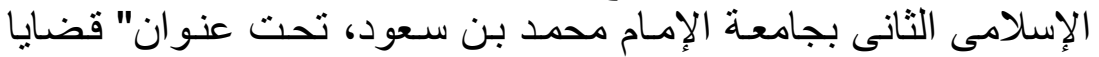

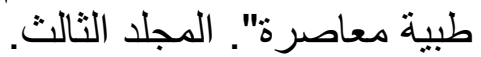

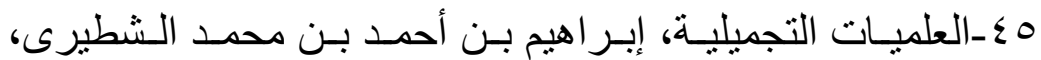

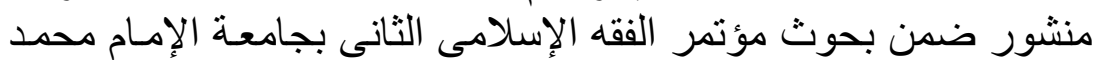

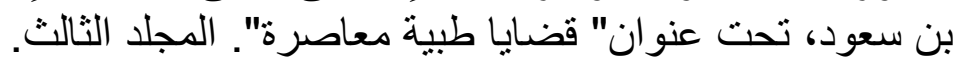

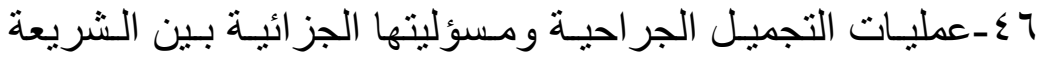
و القانون. محمد الحسينى، طا مركز ابن إدريس للار اسات الفقهية. §V

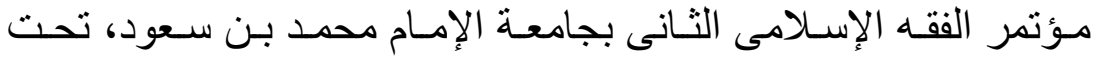

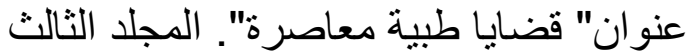

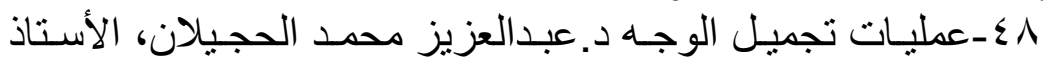
بقسم الفقه بكلية الثريعة جامعة القصيم. بدون طبحة دئة 


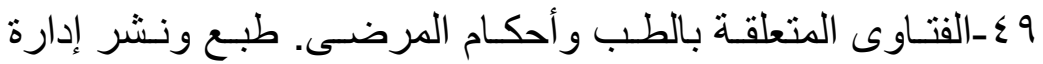

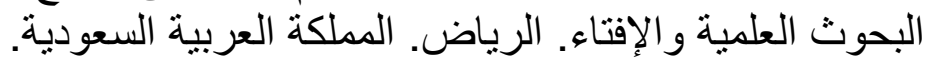

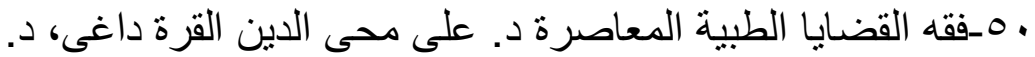
على يوسف المحمدى.ط/ دار البشائر الإسلامية.

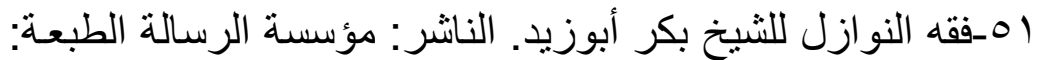

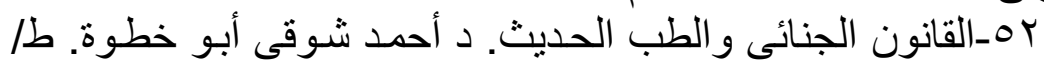

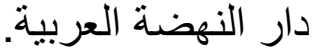

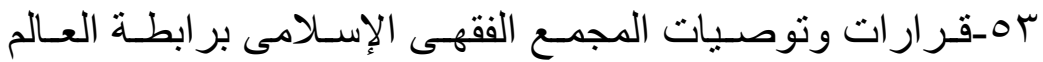

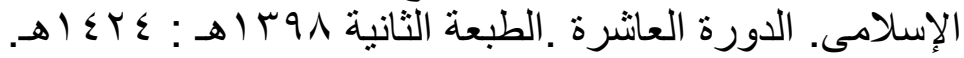

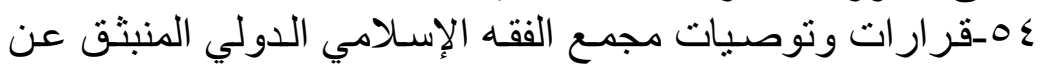

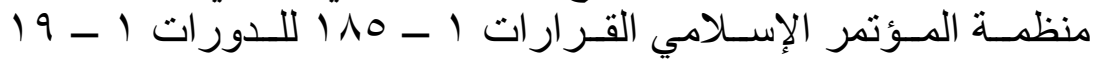

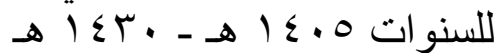

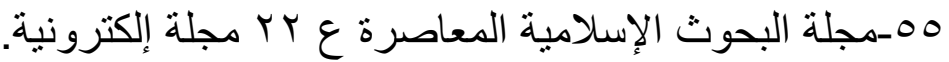

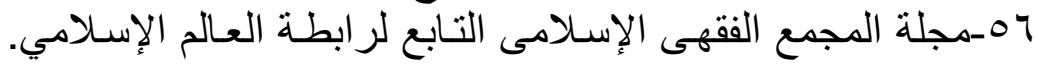
الطبعة الخامسة.

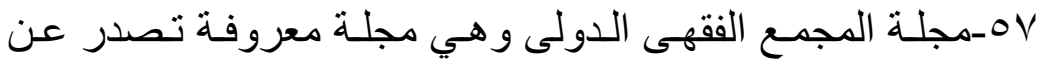

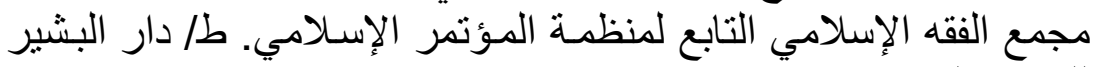
للنشر و التوزيع. 